\title{
PERU:DEFORESTATION IN TIMES OF CLIMATE CHANGE
}

\section{ALBERTO CHIRIF}

\author{
editor
}

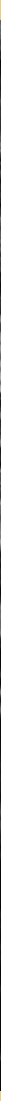

JOSÉ ÁlVAREZ ALONSO • TIMOTHY BAKER • LUISA ELVIRA BELAUNDE MANUEL MARTÍN BRAÑAS • HUGO CABIESES • JUAN LUIS DAMMERT

CARLOS CAÑAS - DENNIS DEL CASTILLO

CLAUDIA MARÍA GÁLVEZ DURAND • EURIDICE HONORIO CORONADO BEATRIZ HUERTAS - IAN LAWSON • MARIANA MONTOYA - THOMAS MOORE SHAPIOM NONINGO • GUILLERMO REAÑO • SANDRA RÍOS KATHERINE ROUCOUX • RICHARD CH. SMITH ERMETO TUESTA ・ JULIA URRUNAGA 




\title{
PERU:DEFORESTATION IN TIMES OF CLIMATE CHANGE
}

\author{
ALBERTO CHIRIF \\ editor
}

JOSÉ ÁLVAREZ ALONSO • TIMOTHY BAKER • LUISA ELVIRA BELAUNDE MANUEL MARTÍN BRAÑAS • HUGO CABIESES • JUAN LUIS DAMMERT

CARLOS CAÑAS • DENNIS DEL CASTILLO

CLAUDIA MARÍA GÁLVEZ DURAND • EURÍDICE HONORIO CORONADO

BEATRIZ HUERTAS • IAN LAWSON • MARIANA MONTOYA - THOMAS MOORE

SHAPIOM NONINGO • GUILLERMO REAÑO • SANDRA RÍOS

KATHERINE ROUCOUX • RICHARD CH. SMITH

ERMETO TUESTA • JULIA URRUNAGA

Lima, 2019 


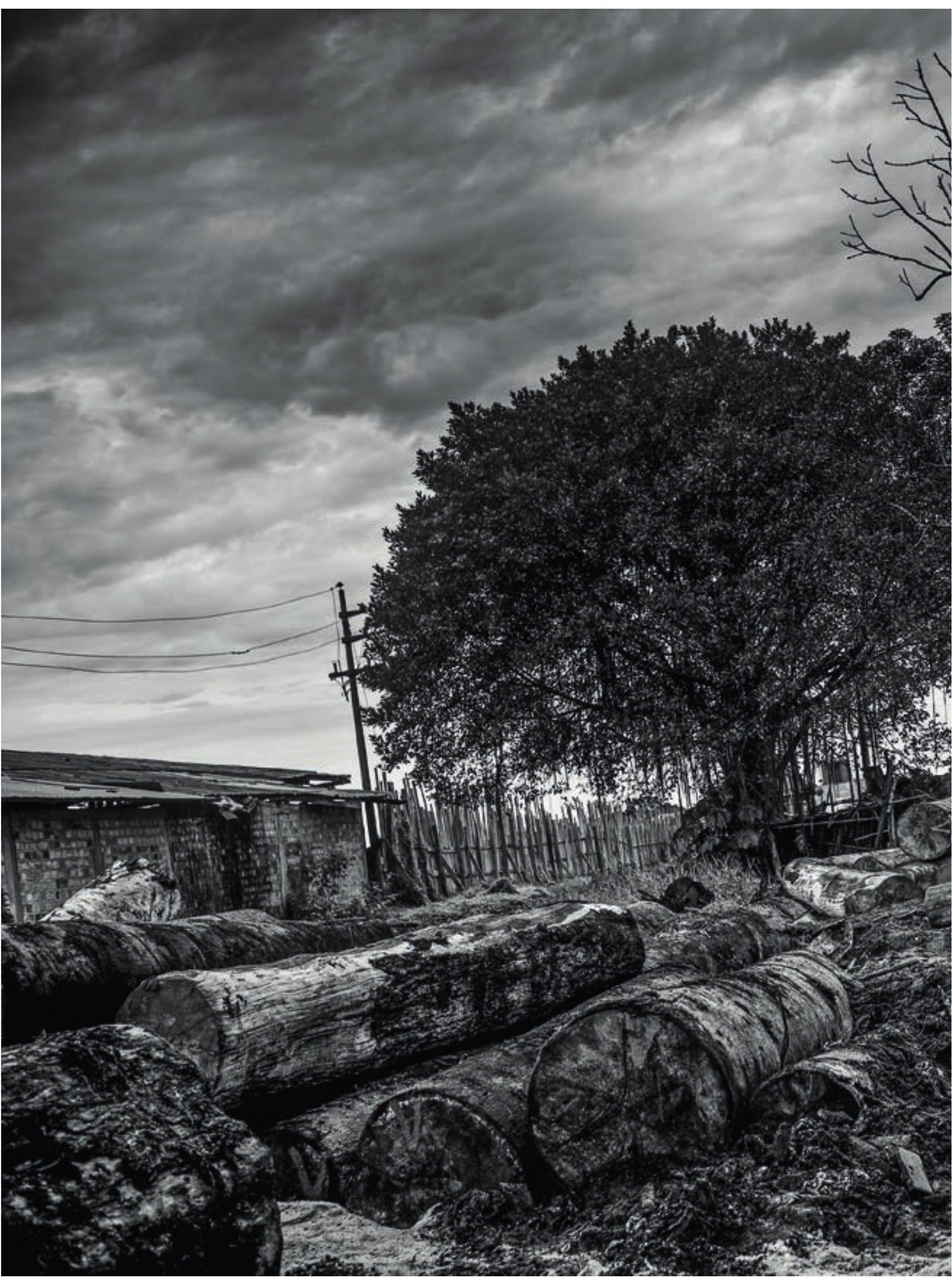




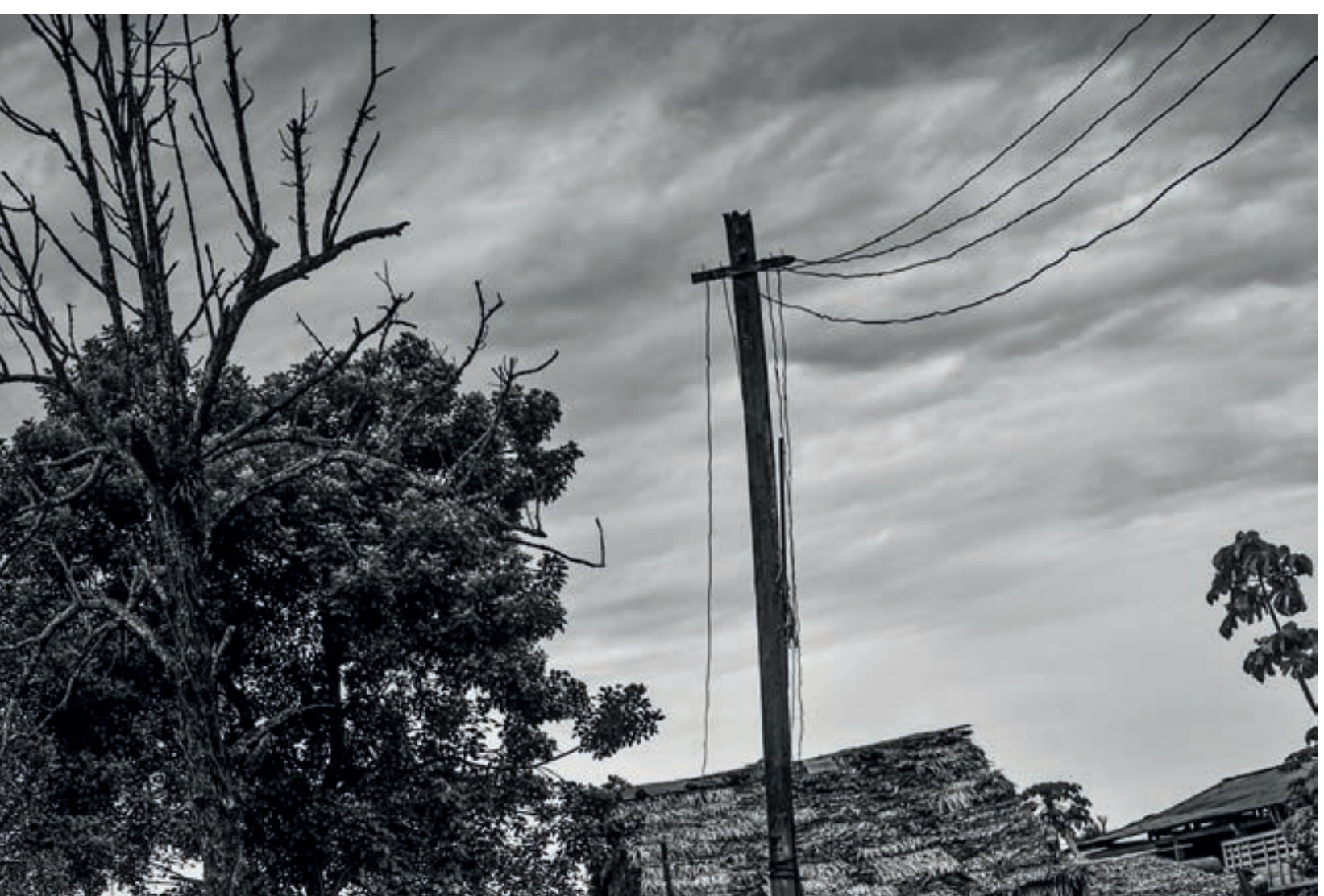
(a)

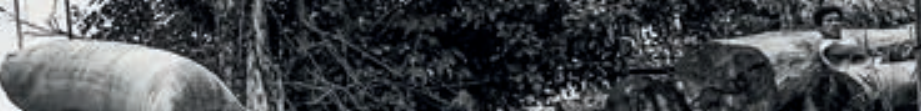

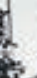
2.1. 2.

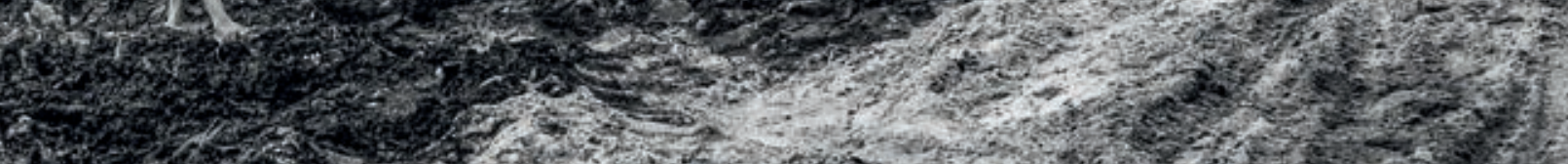

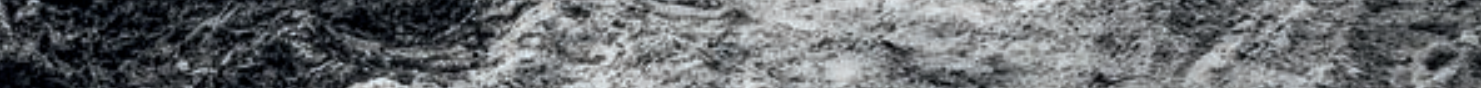

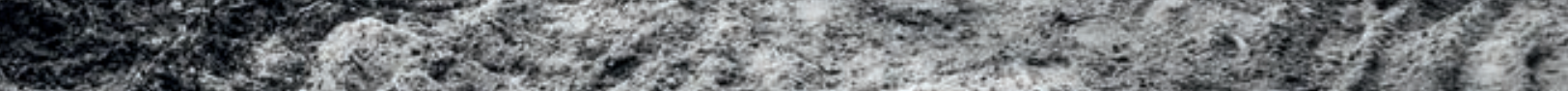
(3)

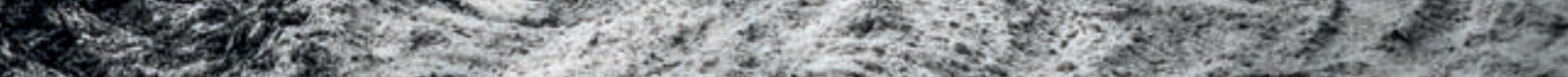

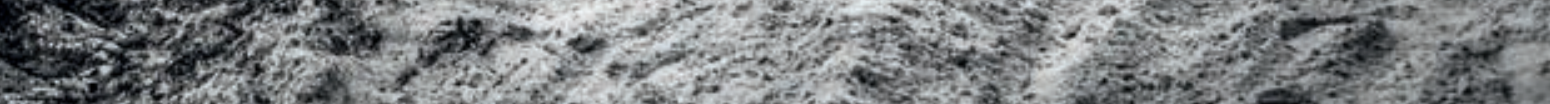

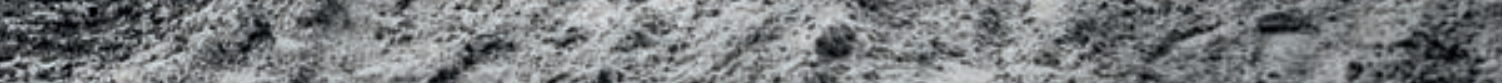

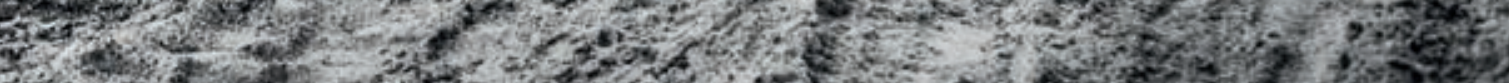

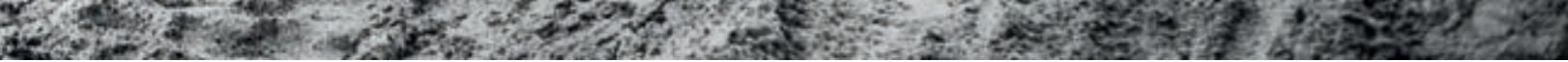




\section{PERU: DEFORESTATION IN TIMES OF CLIMATE CHANGE}

COPYRIGHT: the authors and IWGIA

Compilation AND EDItING: Alberto Chirif

COVER AND INTERIOR DESIGN: Gredna Landolt

Pнотоs: Musuk Nolte (cover AND PAges 4, 7, 8, 12)

Translation: Elaine Bolton, all articles except those by Julia Urrunaga, Timothy Baker and Thomas Moore, which were written in English by the authors.

StyLe Review: Helen Wheeler

ISBN: 978-87-92786-95-1

Legal deposit made in the National Library of Peru: 2019-16255

Printed in Tarea Asociación Gráfica Educativa

Pasaje María Auxiliadora 156, Lima 5 - Peru

\section{HURRIDOCS CIP DATA}

Title: Peru: Deforestation in Times of Climate Change

Edited by: Alberto Chirif

Pages: 286

Language: English

ISBN: 978-87-92786-95-1

Index: 1. Indigenous Peoples - 2. Amazon - 3. Peru

Geographical area: Peru

Publication date: December 2019

INTERNATIONAL WORK GROUP FOR
INDIGENOUS AFFAIRS
Prinsessegade 29 B, 3rd floor DK 1422-
Copenhagen, Denmark
Tel: (45) 53732820 E-mail: iwgia@iwgia.org
Web: www.iwgia.org

Web: www.servindi.org

ORGANIZACIÓN NACIONAL DE
MUJERES INDÍGENAS ANDINAS
Y AMAZÓNICAS DEL PERÚ
Web: www.onamiap.org

CONSEJO HARAKBUT, YINE
COMATSIGUENKA

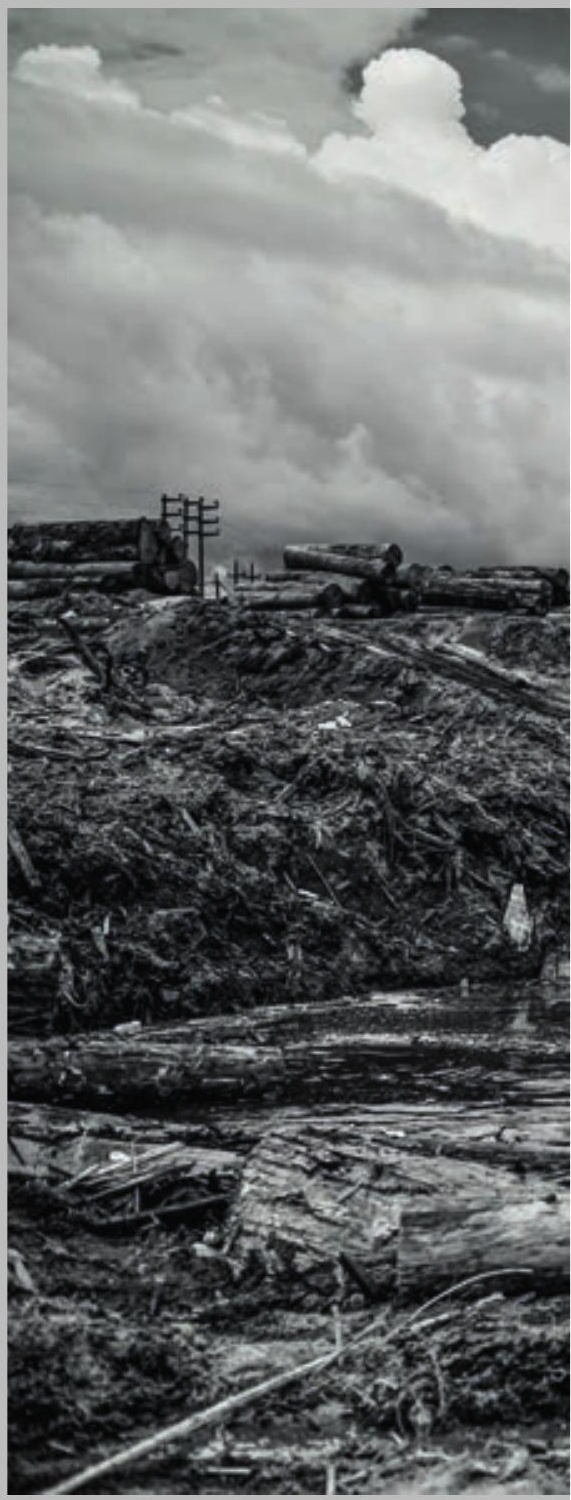




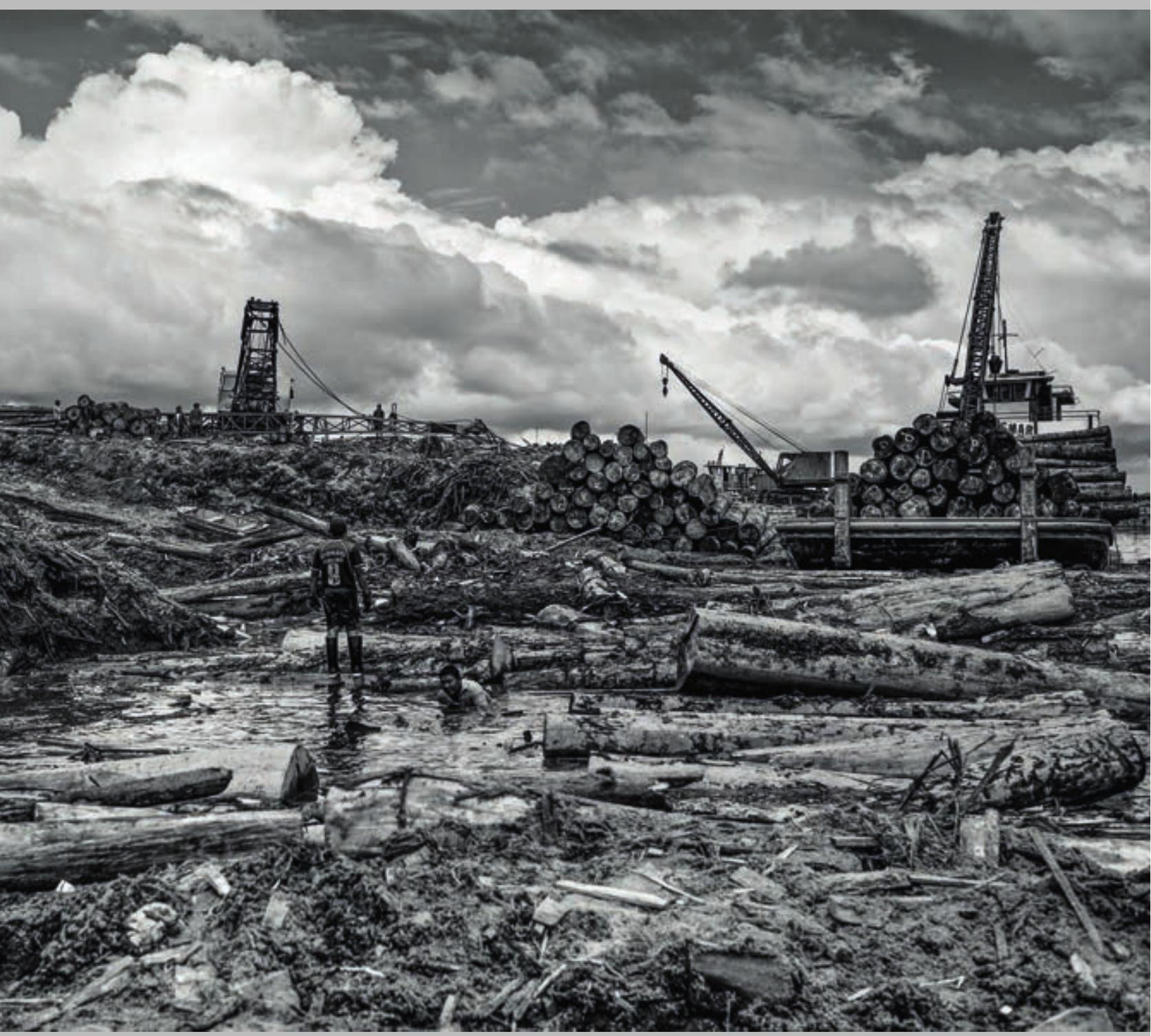

Photo: Musuk Nolte 


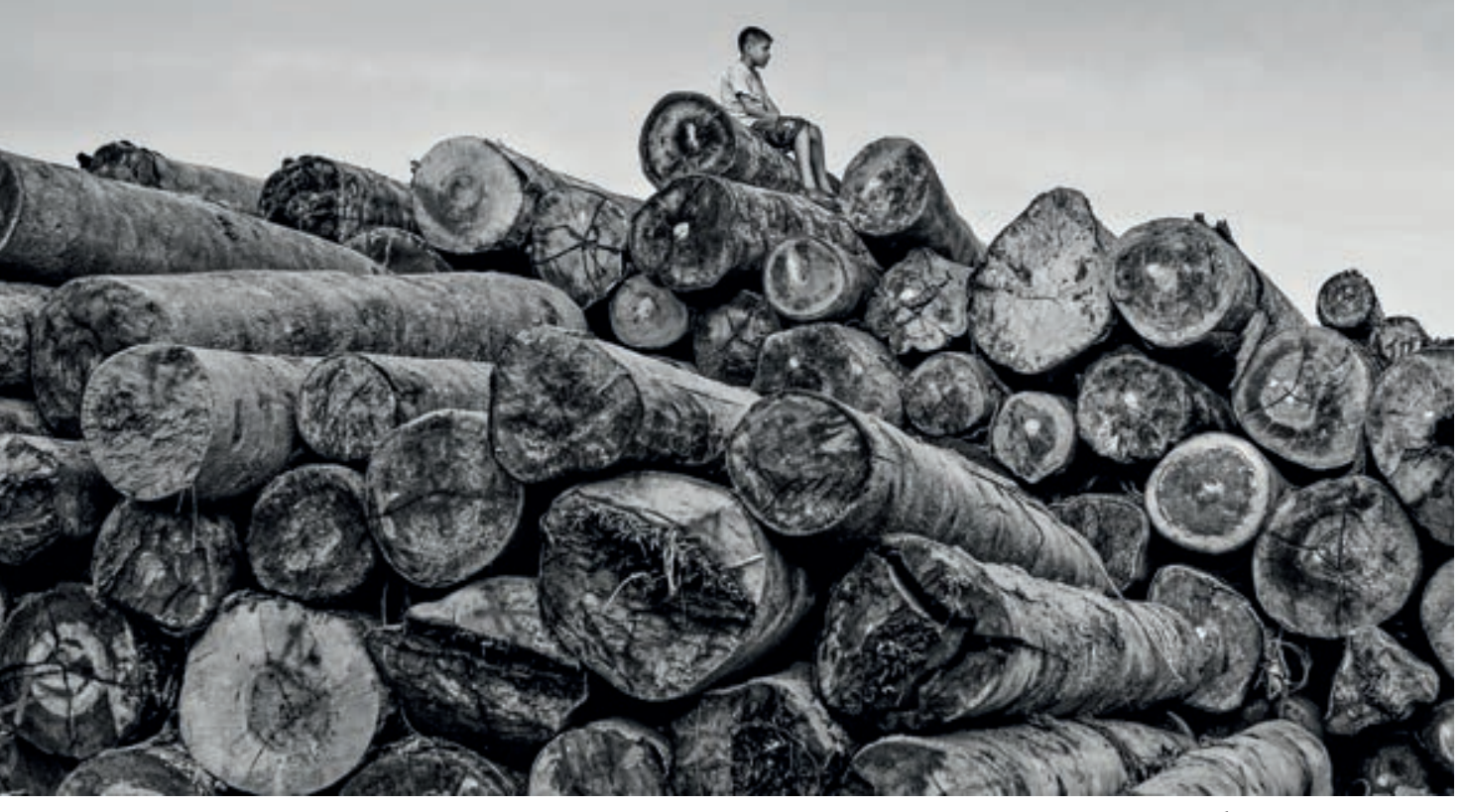

Photo: Musuk Nolte 


\section{CONTENTS}

Deforestation in times of Climate Change

Alberto Chirif

Coca, Forests and Indigenous Amazonian Peoples

Hugo Cabieses Cubas

The growth of oil palm in the Peruvian Amazon: deforestation and land

trafficking

JUAN LUIS DAMMERT

Fighting Illegal Logging in Peru: The government's steps forward and the industry pushback

Julia M. Urrunaga

Forests and Indigenous Peoples Facing Climate Change and Globalisation

José Álvarez Alonso

Autonomous Territorial Government of The Wampis Nation.

Recovering Socio-Historical Autonomy, Building a Common Future

SHAPIOM NONINGO

Deforestation in titled native communities 2000-2015: the cases of the

indigenous Awajún peoples of Alto Mayo and the Kakataibo peoples of the Central Forest

\section{Sandra Ríos Cáceres, Ermeto Tuesta and Richard Chase Smith}

The Defaunation of the Tropical Forests and its Environmental Implications

Claudia María Gálvez Durand Besnard

The Impact of Deforestation on the Water and Fish Populations of The

Peruvian Amazon

Carlos Cañas

The challenges for achieving conservation and sustainable development within the wetlands of the Pastaza-Marañón basin, Peru

Timothy R. Baker, Dennis del Castillo Torres, Eurídice Honorio Coronado, Ian Lawson, Manuel M. Brañas, Mariana Montoya and Katherine Roucoux

\section{ERmeto Tuesta}


Impacts of Hydrocarbon Exploitation on the Indigenous Women of the

Peruvian Amazon

Luisa Elvira Belaunde

Deforestation in Madre de Dios, its implications for first peoples

Thomas Moore

La Pampa, the heart of a mining model that is destroying the forests of

Madre de Dios

Guillermo ReAÑo

The Territorial Corridor of the Pano, Arawak and Other Peoples:

guaranteeing the integrity of indigenous peoples in isolation and initial contact

Beatriz Huertas Castillo

Author biographies

279 


\section{Acknowledgments}

I would like to express my sincere recognition to all the authors who have participated in this book. Thank you for your patience in answering my questions and responding to my comments.

My special thanks to Elaine Bolton, who has translated the majority of the articles contained in this volume, for her excellent work and the good coordination we hace maintained during many months in order to complete this publication.

Alberto Chirif

Iquitos, December 2019 


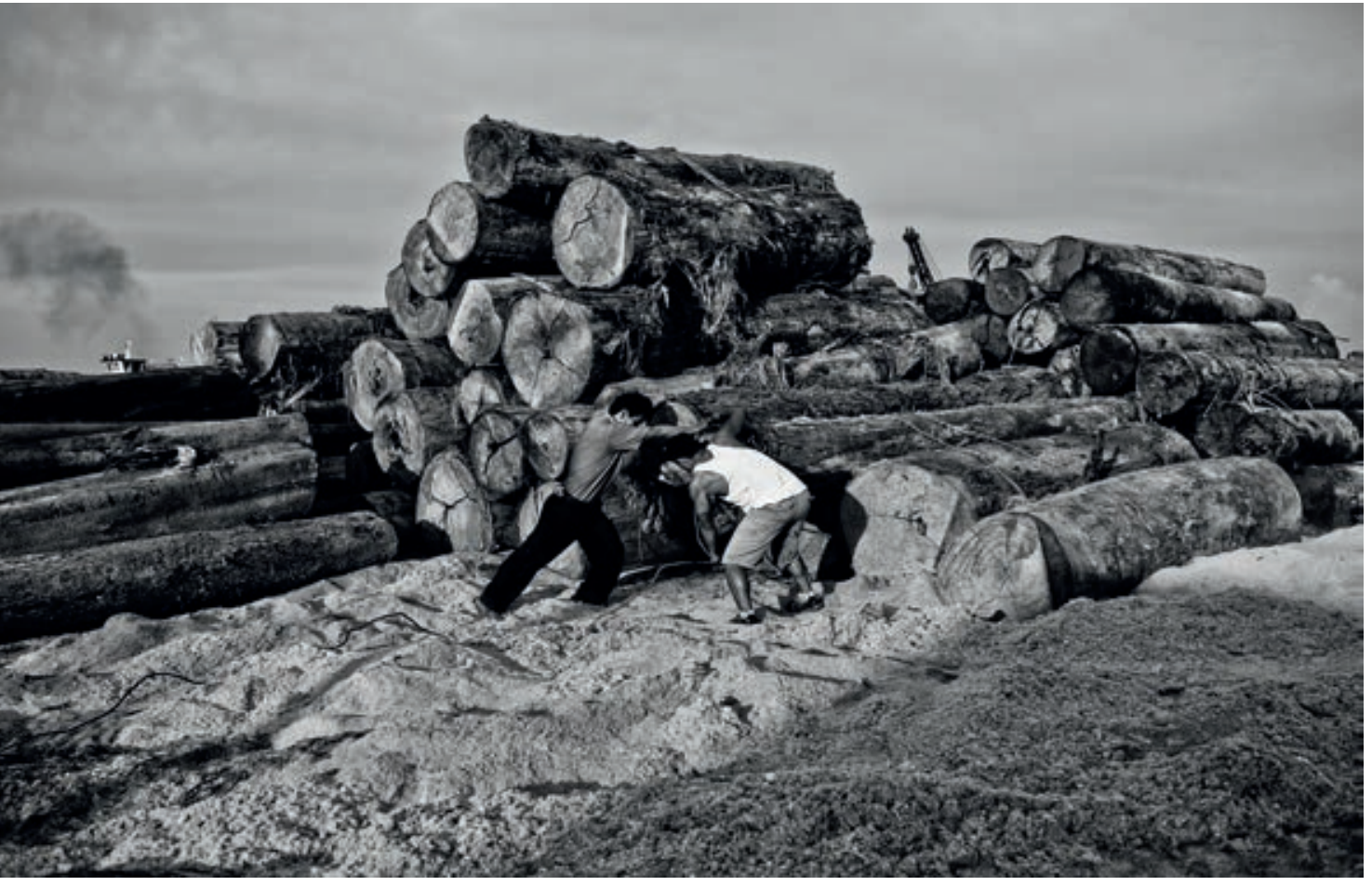

Photo: Musuk Nolte 


\title{
DEFORESTATION IN TIMES OF CLIMATE CHANGE
}

\author{
Alberto Chirif
}

First published in Spanish in 2018, this English edition does not follow the exact same format as the original because, in addition to several new works, two have been removed because they are on topics that are no longer current or which have changed in the last two years and several more have been updated by their authors.

This publication forms part of a project on the Reducing Emissions from Deforestation and Degradation (REDD+) mechanism. The project is being funded by Norway's International Climate and Forest Initiative (NICFI) and is providing support to Servindi (Intercultural Communication Services), Onamiap (National Organisation of Andean and Amazonian Indigenou4s Women of Peru) and Coharyima (Harakbut, Yine and Matsiguenka Council), this latter being a member organisation of Fenamad (Federation of Native Communities of Madre de Dios and its Tributaries) in Madre de Dios. The key aim of the project is to provide training for indigenous communicators and to produce and disseminate information on indigenous rights with a focus on climate change issues, the Norway-Germany-Peru cooperation agreement on REDD + and the indigenous REDD + proposal aimed at titling the communal territories. This work is being undertaken largely in the REDD+ pilot areas: Madre de Dios, Ucayali and San Martín.

One of the project's themes is the drivers of deforestation. To consider this issue in more depth, a workshop was held in Puerto Maldonado (Madre de Dios, Peru) on 26 March 2017 with the participation of communities affiliated to Coharyima and the leaders and technical staff of Fenamad. The primary aim was to analyse the issue of road infrastructure, not only the Southern Interoceanic Highway linking the Madre de Dios region to Acre State in Brazil but also other planned roads that are likely to cross the indigenous territories and protected natural areas.

This work brings together a number of the speeches and discussions that took place during that workshop along with articles written especially by the authors. It comprises a total of 14 articles addressing the issue of deforestation in the Peruvian Amazon and its impacts, not only on the Amazonian environment and wildlife but particularly on the societies inhabiting the area. These impacts are being facilitated by informal dynamics for which the State is largely responsible. It has failed to act promptly enough to put a stop to these dynamics and redirect their drivers towards a sustainable use of the environment and its resources which would, in turn, result in prosperity for the region and the country as a whole. The most harmful of these dynamics is the expansion of illegal coca growing and alluvial mining. The environmental impacts are, nonetheless, also the result of official 
policies aimed solely at promoting economic growth that benefits the investment companies to the detriment of the population and the environment. The State has promoted such policies through a strategy of tax reduction (meaning less public investment in social services such as education and health) and a lowering of environmental standards and social rights, such as job security. Their policies have also included the construction of roads that enable companies and extractors alike to gain easy access to new areas rich in natural resources, and which are then rapidly plundered. As recent judicial inquiries have shown, these infrastructure projects are based on a logic of corruption rather than national interest. As for the indigenous peoples, they are suffering serious aggression aimed above all at minimising, or even trying to abolish, the rights protecting them, such as the guarantee of free, prior and informed consultation as provided by ILO C169, the aim of which is to reach an agreement on initiatives affecting them.

$* * * * * *$

On 23 September 2014, the governments of Germany, Norway and Peru met in New York to sign a letter of intent to cooperate on reducing greenhouse gas emissions resulting from the deforestation and degradation of forests (REDD+) and to promote sustainable development in Peru.

This agreement has, however, failed to change the dynamics already existing in Peru. The statistics show that deforestation has remained steady and has even increased in some areas due to the expansion of coca plantations and agroindustrial crops. There are incomplete statistics on coca and eradication estimates (i.e. manual removal of the plants) scarcely cover 7\% of that sown. Indeed, the crop is constantly expanding towards Peru's lowland forests, some of this centred around the tri-border area between Brazil, Colombia and Peru formed by the confluence of the Yavarí and Amazon rivers. Recent information bears witness to persistent invasions of Shipibo settlements along the Ucayali River by settlers coming from Tingo María, Huallaga Central and Junín, all coca growing areas. It is easy to imagine what they will be doing on lands taken from these communities and the subsequent environmental damage and social tensions this will create. The communities simply continue to submit "briefings" to the regional authorities, who take little notice, as is usual when dealing with complaints made by indigenous peoples. It will be no surprise if the anger these invasions are causing eventually explodes into the same violence as that of the 1980s and 90s.

In terms of agroindustrial plantations, two companies from the same consortium (Melka Group) have been responsible for causing widespread deforestation. In the area of Nueva Requena (Ucayali), Plantaciones de Pucallpa has cleared 13,000 hectares in order to establish oil palm plantations. Cacao del Norte SAC has to date felled around 2,400 ha of forest in Tamshiyacu (Loreto). Both these cases share various features in common and these will be considered below. 
One similarity in the actions of these two companies has been their disregard for the rights of the local population. Nueva Requena is part of the ancestral territory of the Shipibo people. There is a community in the area, Santa Clara de Unchunya, that has rights to the lands taken by the company. Although they do not hold a formal title deed to the property, national legislation and international agreements state that they are the owners of the land they inhabit and possess. Article 14 of ILO C169 thus states: "The rights of ownership and possession of the peoples concerned over the lands which they traditionally occupy shall be recognised". The Inter-American Court of Human Rights has, for its part, made a number of judgements ratifying indigenous peoples' ownership rights. In order to formalise this right, the community commenced proceedings to extend their territory but the Ucayali Regional Government ruled this process inadmissible in order to facilitate the company's settlement of the land. Faced with protests from the inhabitants, the company began to intimidate them and file legal complaints against their leaders.

The Tamshiyacu case dates back to before 2014, i.e. before the signing of the agreement with Germany and Norway. It came to light in September 2000 when the local Iquitos newspaper, La Región, published a report - including photos - of the razing of 2,000 ha of land in the area. The company obtained the land through dishonest negotiations with the owners of a series of 50-hectare plots that had been provided to them during the government of Alberto Fujimori at the end of the 1990s. The deceit lay in frightening the owners into selling their plots before the government could expropriate them for not having worked them fully (this latter threat being a lie). Faced with the fear of losing their lands, they sold their 50-hectare plots for five thousand sol each, a mere 100 sol per hectare. A real bargain. When this trickery came to light the farmers were advised to sue but it was already too late: the company had established itself as owner, registering its holding in the Public Register.

Another common characteristic was the State's behaviour which, when I started writing this introduction I thought to describe as "inactive" but, on further reflection, I have come to realise that it has, on the contrary, been highly active. Its apparent lack of action in monitoring the company's deforestation has not been a consequence of oversight but rather an implicit policy. How so? Because "investment" has become a panacea for the Peruvian State, and it refuses to see the effects of a lack of control. The environment is under massive attack and suffering tremendous devastation. While such action generates big profits for the companies, it is also harming the local people who are suffering a deteriorating habitat. This is the living environment that provides for their well-being through a number of activities that supplement their farming, namely fishing, hunting and forest produce gathering. The way the State sees it, this investment is being obstructed by troublesome "hindrances" (referring to the local inhabitants' rights), all the more so when these inhabitants are indigenous peoples demanding prior and informed consultation, along with environmental permits. In other words, the State is informally acting against its own formal policies given that both citizens' rights and pri- 
or consultation, as well as environmental safeguards, are set out in legislation that it has previously approved. When there is no time to remove these "hindrances" (through the country's already infamous "environmental measures") they simply ignore them.

The path away from the rule of law is not always illuminated by the single logic of economic growth, however. Public officials' interest in obtaining backhanders always plays a decisive role in decision-making. In fact, in the cases of both Plantaciones del Ucayali and Cacao del Norte there are sufficient indications to open investigations in this regard. Suspected "under-the-table" bribes have not, however, prevented the company from being deceived by officials who presented Tamshiya$\mathrm{cu}^{\prime}$ ' lands as suitable for cocoa cultivation. The reality is quite different, not only due to the poverty of the zone, formed largely of white-sand forests (varillales), but also due to the high cadmium content of the soil, which would produce low-quality cocoa contaminated by this heavy metal and be of low value on the international market.

The agroindustrial plantations affecting Santa Clara de Unchunya and Tamshiyacu, together with illegal coca growing, are addressed in the works of sociologist Juan Luis Dammert and economist Hugo Cabieses respectively. This latter borrows the concept of "rogue economy, society and culture" from the economist Loretta Napolioni to refer to the policies and strategies that today govern "development", and which result in a pathetic litany of illegal logging; unlawful mining; smuggling; human trafficking; prostitution; trafficking in children, human organs, cocaine, gold, explosives and weapons; piracy; counterfeiting; kidnapping; corruption; and money laundering. Such "development" is the enemy of the forests, of the Amazon, of indigenous peoples and of citizens' rights more generally, as its sole focus is on the profits accruing to the company. The weight of this rogue strategy in both public and private policies should be borne in mind as you read the articles in this book.

The environmentalist Julia Urrunaga, director of the Environmental Investigation Agency (EIA), addresses the difficult issue of logging in the Peruvian Amazon. According to her sources, between $60 \%$ and $98 \%$ of this is illegal. Together with other researchers, she has published two important works aimed at demonstrating the severity of the problem: La Máquina Lavadora ('The Laundering Machine') (2012) and El Momento de la Verdad ('The Moment of Truth') (2018), both published with the support of the EIA. In the first of these works, the researchers developed a methodology for determining whether the origin of the timber felled by companies was legal or not. This consisted of gathering documents from different Peruvian government agencies and cross-referencing the information contained therein. The results exposed the illegal origin of hundreds of timber shipments departing Peru for the US market. Most tragic of all was the revelation that more than 100 shipments of species protected by the CITES Convention (Convention on International Trade in Endangered Species of Wild Fauna and Flora), the aim of which is to protect threatened species such as mahogany and cedar, had all 
come from illegal sources. If this was the case for protected species, what on earth was happening to species not covered by the Convention?

A series of factors is contributing to this, and these have already been noted by other researchers, ${ }^{1}$ including: the State's negligence, which devotes minimal funding to the forestry sector, making it impossible to exercise any serious control over the companies' activities; the corruption of public officials and other professionals responsible for providing accurate information on forests; and the complicity, indeed corruption, of some State departments whereby companies manage to impose their will to ensure that their interests prevail. It is not that there are no State agencies attempting to do things properly. This can be seen from Julia Urrunaga's article when she mentions Operación Amazonas, which was supported by SUNAT (National Superintendence of Customs and Tax Administration) or the report by Osinfor (Forest Resource and Wildlife Supervisory Body). The problem in these cases is that the more shady sectors of the State collude with the companies to ignore these agencies' findings and proposals or, worse still, weaken them through different mechanisms that even go as far as sacking their managers.

The biologist José Álvarez analyses the impacts of "development policies" on the Amazon and makes a number of interesting proposals regarding how to manage the standing forest. He gives an enlightening view of the many failed attempts to turn the Amazon into something it is not: the setting for extensive cattle farming and immense forestry plantations financed only by ignorance and an over-abundance of money but which have left their indelible mark of destruction. One proponent of this tendency in Peru was President Fernando Belaunde Terry during his two terms in office. Apart from negatively affecting the environment, the huge investments in roads and in failed economic initiatives also triggered a boom in coca growing, a source of violence from which the subversive movements of the 1980s and 90s drew their funding and which is now a central factor in the economic distortions facing the Amazon region. Álvarez' analysis of the model's failure is both clear and overwhelming. Faced with such evidence, he asks: what can be done to generate income for the local population and improve their standard of living without destroying their culture, their social organisation, nor the ecosystems on which their livelihoods are based? He makes a number of proposals which, if I had to summarise them in two words would amount to "biodiversity management".

Looking at the issues from a rather different perspective, the work of the indigenous leader Shapiom Noningo, a psychologist by profession, also makes a proposal, in this case focused on the Wampis people's territorial management of at least part of their traditional heritage. This proposal raises at least two major

1. See, for example, the report by forestry engineer Carlos Cornejo. "Análisis situacional de concesiones forestales, tala ilegal y titulación de tierras forestales en la Amazonía peruana" ("Analysis of the situation of forest concessions, illegal felling and the titling of forest lands in the Peruvian Amazon") (Working document), produced by the Research Institute of the Peruvian Amazon (IIAP. Proyecto Focal Bosques). Iquitos, June 2007. 
challenges. The first is that of ensuring that the State keeps to its word when it signs documents, and that such agreements are enforced rather than remaining dead letter. In fact, the UN Declaration on the Rights of Indigenous Peoples, approved by the UN General Assembly in September 2007, establishes self-determination as the most important right: "Indigenous peoples have the right to self-determination. This guarantees the right to freely determine their political condition and the right to freely pursue their form of economic, social, and cultural development" (Art. 3). This is the first time that an indigenous people in Peru has proposed enforcing this right. The second challenge relates to the current situation of the Wampis people, who will need to establish democratically-accepted rules of governance if they are to be able to face up to the new and complex social, economic and cultural context in which the siren calls of progress have enthralled many indigenous people, both grassroots members and leaders. I believe it will be highly important to put into practice the biodiversity management proposals made by Álvarez as part of the Wampis nation's initiative.

In a jointly-written text, Sandra Ríos, Ermeto Tuesto and Richard Chase Smith compare cases of deforestation in the communal territories of the Awajún peoples of Alto Mayo and the Kakataibo people of the Central Forest. The Awajún communities obtained their titles from 1975 onwards but, shortly thereafter, at the initiative of their leaders, they began to divide up their lands, not legally but in practice, so that each family could use their plot as they saw fit. The rhetoric used by these leaders was a "modernising" one, in the style of the politicians: indigenous peoples have a right to progress, and renting out their lands is one way of making money.

There is a strong presence of Andean settlers from the neighbouring region of Cajamarca in the Alto Mayo area where these communities are settled. As settlers, their main focus is on rice-growing. They have signed land rental agreements with the Awajún although these latter received no legal advice with regard to setting terms that would have enabled them to safeguard their territorial rights and obtain some benefit from the arrangements. The contracts therefore have no termination dates and nor do they establish any conditions that would protect the indigenous people's property, for example by prohibiting the settlers from building concrete and brick houses, establishing commercial undertakings, or sub-letting the land to relatives and others. The end result has been a real loss of Awajún control over their communal lands. They have now realised the severity of the situation and are trying to rectify it. The number of settlers and the permanence of their settlements, however, means the Awajún have little chance of recovering their heritage.

For their part, the Kakataibo communities - crossed by the highway linking Pucallpa to the coast - are suffering settler invasions and, like the Awajún of Alto Mayo, some of them have decided to divide up their lands so that they can rent them out. These settlers come from the neighbouring regions of Huánuco, Junín and Pasco. These areas are over-populated and illegal coca growing has taken off in the forested parts of these regions in recent decades, particularly since the 1980s. Two processes coalesced during that decade that were to end up complementing 
each other: strong State investment in the settler project, including improvements in road infrastructure; and the presence of subversive groups benefiting from these new roads to expand coca growing in order to fund their activities, controlling the market for basic cocaine paste and cocaine hydrochloride. In addition to coca, there are also other crops and pastureland. In its desire to counter the illegal coca growing, the State has been promoting the expansion oil palm plantations and fruit trees, such as papaya and cocoa, thus further contributing to the deforestation being caused by the settlers.

The impact on wildlife and fisheries is considered in the works of Claudia Gálvez and Carlos Cañas. Claudia heralds the great diversity of tropical forest species in comparison to other land-based ecosystems along with their central importance in balancing the global climate and as a strategic reserve of genetic resources and fresh water. She analyses the drastic decline in many mammal populations, particularly larger mammals, caused predominantly by the human activity that is resulting in the disappearance or impoverishment of the forests. These forests and their wildlife are key elements in the subsistence and low-scale market economy of the indigenous and local populations, and so these impacts are having a severe effect on them. One important issue in this discussion is the interdependence between forest and wildlife. The wildlife requires the forest to live and the forest requires the wildlife to regenerate, with the animals providing seed dispersal.

Carlos Cañas also highlights the important benefits provided by Peru's Amazonian forests in the form of timber, fruits and edible plants, along with resins and creepers, all used by the local population in their food and to treat their illnesses. The different species of wildlife living therein supply the indigenous peoples with animal protein. His focus lies particularly on the benefits the forest provides for aquatic ecosystems, however. These are many and varied as the trees protect the riverbanks from erosion, provide shade and regulate the water temperature, as well as playing a key role in humidity maintenance and in the water cycle. The author notes the physical and chemical relationships between aquatic ecosystems and forests and the important role fish play in forest regeneration through seed dispersal.

In a joint article, Timothy R. Baker, Dennis del Castillo Torres, Eurídice N. Honorio Coronado, Ian Lawson, Manuel Martín Brañas, Mariana Montoya and Katherine Roucoux all address the issue of the Pastaza-Marañón wetlands, home to the greatest known complex of peatlands in the Amazon. These peatlands comprise deep layers of organic material on permanently wet soils the subsoil of which is home to the most dense deposits of carbon in the Amazon forest. The wetlands also form part of the ancestral territory of indigenous peoples who hold a wealth of knowledge on the forest and its uses. The dominant species here is Mauritia flexuosa (a palm known locally as the "aguaje"), which is of huge economic potential as it is being increasingly relied upon as an input for the manufacture of ice creams, homemade soft drinks and processed beverages.

The view that the Pastaza-Marañon forests are of low value in terms of their underground carbon storage capacity has changed significantly in the last 
few years. Scientific research conducted in recent decades has demonstrated the potential of these ecosystems to store large amounts of organic matter. In fact, observations suggest that these forests can store large quantities of carbon in the subsoil, estimated at more than $600 \mathrm{Mg} C$ ha in peat.

This is an ecosystem that has survived to this day unharmed, despite a long history of occupation by indigenous peoples. It suggests that occupation of a territory does not have to run counter to the good use of the environment or, put another way, that the environment can be preserved by managing the ecosystem and making the most of its benefits. In addition to the oil exploitation that has been ongoing for decades, resulting in constant oil spills and dumping of wastewater, there are a number of threats facing this area: the Amazon Waterway Project, which will require the dredging of different points along the Marañon and other rivers with unforeseeable consequences for the aquatic wildlife and wetland plants; and the planned highway linking Iquitos with Saramiriza in order to connect Loreto to the national road network. This highway would follow the route of the road already opened up by the oil companies, which runs along the border with Ecuador and crosses the upper courses of the Tigre, Corrientes and Pastaza rivers, highly sensitive areas if subjected to violent settlement processes and uncontrolled resource extraction. Such projects would threaten the wetland carbon deposits and ruin the progress made in enhancing the value of such an important resource as Mauritia flexuosa

Ermeto Tuesta looks at the impacts of the road infrastructure running through native communities on the local people's living conditions. He illustrates his text with numerous maps demonstrating the deforestation that is taking place. He presents the cases of Awajún communities affected by the Bagua-Nieva-Saramiriza (Amazonas) highway; Shawi communities split by the Tarapoto-Yurimaguas-Balsapuerto (Loreto) road and who are renting out their lands to settlers to sow rice, coffee, papaya and banana; and the Awajún communities of Alto Mayo, already mentioned above in relation to the work of Ríos et al. With the establishment of these roads, farmers from elsewhere are able to access the area and sign agreements with community members to rent their lands in order to grow different crops or harvest timber, activities that are undertaken without any forest management plans to regulate them. In the case of Madre de Dios, many community members are "inviting" people in to mine for gold, an activity that is clearly profitable for both parties but which is destroying the environment by removing large quantities of alluvial soil and contaminating the air through burning mercury. The State's role as usual is one of indifferent bystander.

Luisa Elvira Belaunde's work begins by challenging an assumption that was common until just a few years ago: that the impacts of extractive activity were affecting men and women equally and so no gender analysis was needed in any studies. This androcentric vision was challenged by a number of female researchers who managed to change the focus. The key point that Belaunde makes is that the monetisation of the indigenous economy has a direct impact on the social and eco- 
nomic organisation of indigenous societies and has led to the declining importance of women in gender relations.

Madre de Dios has the most protected natural areas in the whole of Peru. Three national parks lie within its jurisdiction: Manu (part of its territory is in Cusco; it is also a biosphere reserve), Bahuaja Sonene (part in Puno) and Purús (part in Ucayali); two national reserves: Tambopata Candamo and Purús (part in Ucayali); one communal reserve: Amarakaeri, a real triumph for the indigenous movement; one territorial reserve for groups in isolation: Madre de Dios; and a dozen private conservation areas aimed at research and tourism. The State's efforts to conserve the environment and manage the resources of this region would seem to be clear, defined and coherent. This is not the case, however, because at the same time gold mining has represented one of the worst attacks on the environment, contaminating the air and rivers with mercury, altering the landscape, diverting ancient water courses and clogging up river beds and lakes, leading to flooding. It is not enough to label this activity as illegal or informal because this is simply a State pretext to try and cover up its responsibility for generating this chaos, either by omission (abdicating its regulatory and supervisory role) or action (promoting chaos through the uncontrolled issuing of gold mining licences). To make matters worse, all this is taking place under brutal conditions of worker exploitation, some of whom are children being held as slaves or being forced to prostitute themselves.

The articles by Thomas Moore, Guillermo Reaño and Beatriz Huertas bear particular witness to this. Thomas Moore gives a documented account of deforestation in Madre de Dios, indicating the underlying causes over time. His main objective is to analyse how these processes have affected the region's indigenous peoples. He presents the cases of highways that have penetrated their lands, including the recent Southern Interoceanic Highway, the first highway linking the national road networks of Brazil and Peru; gold mining; the development of agricultural, livestock and agroindustrial activities; illegal coca growing; the extraction of timber forest products; and the exploitation of hydrocarbons as well as the threat of hydroelectric power stations that would destroy crops, settlements and even part of the new highway to Brazil. He attributes the main cause of the environmental disaster being suffered by Madre de Dios to the inability of national and regional governments to agree more appropriate policies, the main reason for this being a lack of political will.

Guillermo Reaño begins his work on La Pampa in Madre de Dios (a name that describes the desolate condition in which this area has been left following the uncontrolled exploitation of gold) by citing the results of research comparing gold mining during two distinct historical periods: the first running from 1438 to 1532, during the Inca Empire, and the second from that year onwards. Studies conducted on the Quelccaya Icecap, in Cusco, bear witness to the toxic emissions resulting from colonial metallurgy that were already contaminating the Andean atmosphere in 1532, while the previous Inca period had not resulted in any major changes in the health of Pachamama ('Mother Earth'). The author notes that, 240 years prior to 
the start of the Industrial Revolution, the mark of damaging human activity was already visible on the environment of South America.

It is a tragic finding that challenges the rallying cries of those who defend mining in Peru as the country's natural vocation. Although gold and other minerals were clearly mined during the Inca Empire and previous civilisations, their importance lay in their use in religious rituals rather than the greedy accumulation of wealth in the hands of a few who, to achieve this, fail to consider either the environment or the health and welfare of the local population. The great contribution of the civilisations that previously inhabited the central Andes, today's Peru and Bolivia, was the domestication of animal and plant species, something the whole world today benefits from.

On 19 February 2019, with army and police involvement, the State conducted a huge operation that resulted in the destruction of mining camps and the confiscation of a large amount of machinery: engines, rafts, dredgers, tractors, gold burners and transport vehicles. The aim was to eradicate illegal mining from the area thus recovered and to initiate a plan of action for the environmental rehabilitation of the degraded zone. This was not, however, the first operation of its kind to be undertaken. Previous attempts, implemented with a fanfare of staff and press releases, had ended with no tangible results and with the illegal activities continuing to destroy the environment of La Pampa. There were therefore reasonable doubts as to whether this attempt would be any different or whether the initial impetus would fade once more into oblivion. There are also doubts as to whether the actions they are intending to undertake are actually the best for the area's environmental recovery and whether it will even be possible to rehabilitate the area given the extent of contamination and destruction that has occurred. These and other doubts are raised in Reaño's work.

Beatriz Huertas' work looks at the issue of the Pano, Arawak and Other Peoples Territorial Corridor along the Peru-Brazil border. Corridors are continuous landscapes that are home to a high level of biological and cultural diversity, including the presence of indigenous peoples some of whom are living in isolation or initial contact. Parts of these peoples' territory are protected by different legal concepts specific to each country: indigenous lands in Brazil and native communities in Peru. The large number of protected natural areas in this corridor, some of which are strictly protected (national parks), in theory plays an important role in protecting the habitat of these peoples. Peruvian legislation has, moreover, developed two further legal concepts: communal reserves, benefiting the native communities settled in that environment; and territorial reserves to protect the territory of the peoples living in isolation and initial contact.

In addition to the severe impacts of gold mining in this corridor, which is considered in detail by the other two authors writing on Madre de Dios department (Moore and Reaño), there is the threat of road penetration, whether minor routes cleared by logging companies to extract timber or major highways. The for- 
mer are opened up simply at the decision of the companies, frequently with the support of local power groups who directly or indirectly benefit from their activity. The State is merely a disinterested spectator in the development of this activity and in the social and environmental consequences that such roads may create.

The State has played a corrupt role in the construction of large highways such as the Southern Interoceanic Highway, lying about the boost in trade this would create with Brazil. This demonstrates that the only purpose of the road was to generate profits for the construction companies and for the presidents and authorities who facilitated a way to deliver the contracts.

Beatriz Huertas' work considers the social and environmental impacts of these roads, and emphasises the vulnerability of peoples living in isolation and initial contact who lack the immunological defences to fight off infectious diseases brought in from outside.

These 14 works will undoubtedly provide a better understanding of the situation of Peru's forests, and help to provide a documented assessment of the distance between the rhetoric of statements and documents signed and the reality of what is happening in practice.

Iquitos, September 2019 



\title{
COCA, FORESTS AND INDIGENOUS AMAZONIAN PEOPLES
}

\section{Hugo Cabieses Cubas}

\begin{abstract}
"In recent times, we have seen how age-old cultivated crops such as coca, which were always used in a peaceful and creative way by the native communities in their knowledge rituals or to access the mystical ecstasy of their own cultures, have been snatched from their ancestral use by the frenzy of industrial society and turned into fateful powers. In the midst of poverty and inequality, this in turn boosts the brutality of the mafias and encourages the rapacity of the market." (Ospina, 2013: 252.)
\end{abstract}

\section{Introduction}

According to a report published by the Interethnic Association for the Development of the Peruvian Forest (Aidesep) and Forest Peoples Programme (FPP), entitled "Haciendo visible lo invisible" (Making the Invisible Visible) (Aidesep-APP, 2014), Peru became the largest producer of the coca leaf in the world in 2011. That year, more than 60,000 hectares were grown of a plant which millions of Peruvians, primarily indigenous inhabitants but also many settlers, consider sacred, untouchable, a central element of their world vision and good customs, and an important source of income. This was in comparison to the 48,000 hectares grown in Colombia that same year, according to the United Nations Office on Drugs and Crime (UNODOC).

Yet, in contrast to official discourse, and according to the stated report, the annual deforestation attributable to these crops was only 1,500 ha, little more than $1 \%$ of the total deforestation of the Peruvian Amazon. It is estimated that shifting cultivation is deforesting between 60,000 and 70,000 ha per year, cattle rearing between 40,000 and 48,000 ha and mining between 5,000 and 7,500 ha (Aidesep-FPP, 2014: 33).

What is clear is that the potential significance of this ancestral plant in relation to the decline in forest area can be explained not only by the rapid loss of soil nutrients once the coca has been harvested, but also by the crop eradication actions carried out (more than 20,000 ha per year). Both of these outcomes force producers to shift to another forest area, causing coca cultivation to expand more rapidly than other crops. On top of this there is also deforestation occurring due to the monocropping being promoted by the government through its so-called "alternative development", with support from international cooperation, and involving coffee, cocoa, oil palm, palm hearts and other forms of agribusiness. Moreover, the processing of the coca leaf into cocaine requires the use of highly toxic substances such as kerosene, sulphuric acid and acetone, the residues of which are dumped into the rivers and lakes. 
The Aidesep-FPP study holds that: "In addition to its environmental impact, coca growing is associated with other dynamics and social problems. There seems to be close cooperation between the loggers and drug traffickers insofar as the loggers cut down the trees and, once the land is clear, the traffickers plant coca. Furthermore, some of the settlers that are having the greatest effect on the indigenous peoples of the Ucayali and the Lower Urubamba regions come from the Apurímac, Ene and Mantaro River Valley (VRAEM), because it is now not only the communal lands that they occupy" (Aidesep-FPP, 2014: 34).

As Robert Guimaraes, a Shipibo and vice-president of Feconau (Federation of Native Communities of the Ucayali and its Tributaries), notes: "The settlers bring with them a range of illegal activities, such as timber extraction, coca cultivation and gold mining, and indigenous leaders who try to prevent these invasions receive death threats. Some of them have even been murdered, as recently as 2013. A leader from the Callería basin, of the Patria Nueva indigenous community, was murdered by illicit coca growers who entered the communal territory" (Ibíd.: 34).

In his article "Auges y caídas de las organizaciones indigenas" (Booms and Busts of Indigenous Organisations), the anthropologist Alberto Chirif states that: "Indigenous organisations have made significant progress since they first appeared, particularly in terms of managing to raise the proposals and rights of a social sector which, up to that point, had been denied its own voice at the national level. As regards specific objectives, there are two worthy of note: the territorial demands made through the implementation of an indigenous land titling strategy and the implementation of a teacher training programme from a bilingual intercultural perspective..." (Chirif, 2013: 139).

Three years later, Chirif asked in an article: "What kind of country are we living in when a company - national or foreign ${ }^{1}$ depending on the case - can destroy tens of thousands of hectares of forest without any kind of control from the authorities, whose best justification seems to be that they have not authorised anything. They may not have authorised the deforestation, but neither have they authorised any kind of control measures to prevent it!" In other words, as we shall see further on, this is an absent State, complicit in deforestation, which neglects and works against the population, particularly the indigenous peoples. This is a State that does not stand up to savage and corrupt companies but treats them with kid gloves, while the indigenous peoples, and the population in general, are treated dismissively, neglectfully and violently.

In this article, we shall develop the following elements: we shall look at the economy and the "rogue culture" that supports the "three scourges" of the Amazon and the forests; provide information on how organised crime has become global; provide the most recent information (2015) on coca growing and its links to

1. See: https:// sophimania.pe/medio-ambiente/ contaminacion-y-salud-ambiental/en-que-pais-vivimos-la-deforestacion-en-la-amazonia-peruana/ 
rural development, including the traditional and beneficial industrial uses of coca leaf; explain "alternative development strategies", namely lasting and sustainable comprehensive rural development with coca (DRIS-C); describe the Amazon basin and the Protected Natural Areas (ANP); highlight Peru's gastronomic vocation; promote Comprehensive, Lasting and Sustainable Eco-Ethnodevelopment (EEDISS); and, finally, consider REDD and its links to indigenous peoples. I shall end with a number of preliminary conclusions and recommendations.

\section{A rogue culture against the forest}

Judging by the most recent indicators from a random reading of the print media, rather than ensuring growth with sustainable development, and respecting our biodiversity, food security and "social inclusion", Peru's governments have instead been consolidating a rogue economy, society and culture for the last 30 years. This concept was coined by the economist Loretta Napoleoni (Napoleoni, 2010) and can be evidenced in policies and strategies that are no friend to the forests, the Amazon, or the Amazonian indigenous and forest peoples (Gasché and Vela, 2012).

The sociologist Francisco Durand holds that Peru has been fractured (Durand, 2006) into the formal, the informal and the criminal (FIC). In other words, a FIC economy, society and culture. I would further suggest that the " $\mathrm{C}$ " sector involves not only illicit drug trafficking (IDT) but also illegal felling, criminal mining, smuggling, human trafficking, prostitution, the smuggling of people (migrants), children and organs, of chemical precursors ${ }^{2}$ for cocaine production and gold mining $^{3}$ and of explosives and arms. It also involves piracy, money counterfeiting, biopiracy, kidnappings and contract killings, cyberpiracy, corruption and, finally, money laundering, which encompasses all of the aforementioned categories.

My argument is that the three scourges of the Amazon, its forests and indigenous and forest peoples are: a rampant neoliberal and export-extractivist formal sector that is destroying natural resources, water, biodiversity, rights, cultures and democratic governance; an informal sector that is acting as a refuge from the neglect of the market, State, civil society and ruling politicians, and which is also plundering nature, concealing poverty indicators and destroying the social fabric of solidarity, imposing an "every man for himself" mentality; and the criminal depredation of natural resources, destroyer of people, honour, institutions, democratic spaces and ancestral cultures.

These sectors are coordinated and there are synergies between them. They form the main modern scourges of the rights of communities, citizens, Mother Earth, of the sources and uses of water, the forests, biodiversity, food, health, cul-

2. Inputs for cocaine production, such as acetone, ethyl ether, petrol, kerosene, potassium permanganate, sulphuric acid and hydrochloric acid, to name a few.

3. Such as mercury, arsenic, cyanide, sulphuric acid, solvents to separate the minerals, nitric acid, ammonium nitrate, petrol, lead, etc. 
tures and territorial rights. These rights are the first to be ignored by rampant illegal extractivist activities, conducted without any socio-environmental or cultural barriers as would be legally imposed in developed countries. Where there are informal and criminal activities, the situation is even worse, and with greater impact.

I maintain that no less than $25 \%$ of the Peruvian economy and $30 \%$ of the population are affected by these illicit and informal activities, as well as by organised crime and systemic corruption. In a personal communication in 2013, based on information from a number of different secondary sources, forestry engineer, Lucila Pautrat, executive director of the Peruvian Society for Ecodevelopment and chair of the School of Government and Public Policy at the Pontifical Catholic University of Peru, produced the following table. This demonstrated how much the cost of the environmental damage, informal sector and criminality could be: more than US\$ 103 billion, equivalent to 52.4\% of Peru's GDP in 2012.

Table 1

Conservative estimates of the damage caused by environmental, informal and criminal activities in Peru 2012

(based on secondary sources)

\begin{tabular}{|c|c|c|}
\hline Indicators & Millions of USD & $\%$ GDP (1) \\
\hline $\begin{array}{l}\text { 1. Costs of environmental } \\
\text { degradation }\end{array}$ & $11,352,600$ & 4.0 \\
\hline 2. Informal economy & $66,223,200$ & 35.0 \\
\hline $\begin{array}{l}\text { 3. Informal labour: } 75 \% \text { of the } \\
\text { economically active } \\
\text { population }\end{array}$ & ? & ? \\
\hline 4. Informal mining & $2,000,000$ & 1.0 \\
\hline 5. Illicit drug trafficking & $5,187,000$ & 2.7 \\
\hline 6. Environmental crimes & $1,019,000$ & 0.54 \\
\hline 7. Corruption of officials & 189,000 & 0.01 \\
\hline 8. Cost of corruption in Peru & $7,568,400$ & 4.0 \\
\hline $\begin{array}{l}\text { 9. Human trafficking: } 35,000 \\
\text { victims }\end{array}$ & ? & ? \\
\hline \multirow[t]{2}{*}{ 10. Cost of crime } & $9,649,700$ & 5.1 \\
\hline & $103,189,000$ & 52.4 \\
\hline
\end{tabular}

1) Gross Domestic Product for 2013 was USD 189,250 million, according to the Ministry of the Economy and Finance (MEF).

Sources: World Bank, Pontifical Catholic University of Peru, Superintendency of Banking and Insurance, Transparency International, Presidency of the Council of Ministers, Ministry of the Interior, Ernesto Ráez Luna and former Congresswoman Marisol Pérez Tello. 
In a talk given in 2016, Ms Pautrat maintained that: "Corruption does substantial social, economic and institutional damage to citizens and the State. To the ethical, legal and institutional implications of these crimes, and the loss of public resources, must be added the creation of conditions for inequity and public service funding allocations that exacerbate the impacts of poverty. On 13 December 2015, Peru's Comptroller-General, Fuad Khoury, indicated that the cost of corruption in Peru was estimated at 11 million sols (8.94\% of GDP in 2015), "a figure that could double without firm and rapid action in terms of cases being prosecuted for crimes of corruption" (Pautrat, 2016: 5).

A UNODC report entitled: "The economic cost of organised crime in Peru: a study into the direct costs of crime for the State and families" cited the following:

"Based on a survey of the stated costs incurred by victims of organised and other crimes, as well as the protection measures adopted against them, it has been estimated that the overall annual cost to the Peruvian population is a total of 1,705 million Peruvian Sols. Of this amount, almost $83 \%$ can be explained by the adoption of protection measures, which turn out to be a significantly greater burden on the wealthier sectors of the population. Costs due to hospitalization, rehabilitation, days without working in recovery, permanent damage due to injuries and so on account for only $17 \%$."

The environmental researcher from the Catholic University, Eduardo Musso - who passed away in January 2014 - described the geographical set-up of Peru as follows: "In sum, the coast is a discrete archipelago of oasis in a sea of sand. The mountains form an immense archipelago of crevices in a sea of hills. The jungle is an archipelago of tropical forest in an immense sea of freshwater. Just $4 \%$ of this Peruvian territory comprises the three variables of nature - climate, water and land - that make it inhabitable and viable in terms of agricultural and livestock farming" (Musso, 2012).

From this synthetic description and point of view, our country is made up of a complexity of archipelagos that have water at their heart, and for whose existence sustainable forest management is the number one priority. This is particularly significant given the country's potential as a maritime, forested, agricultural, fishery-oriented and river-based economy rather than one based primarily on mining, as has been repeatedly claimed since the 1990s in particular. There is therefore no option but to learn from our past, understand its nature and adapt to our territory with an eye to the future, just as the Amazonian indigenous peoples do. Geography, ecology, hydrology, climate, cultures and demography all demand that we address and understand the diversity and variability of our country, and this requires that we plan the territory according to its potential and promote another more rational form of development.

Yet for the Minister of the Economy and Finance, his lobbyists, advisors and "high-end" technocrats, as the current Peruvian president (with US nationality) calls them, the "C" (criminal) sector does not exist or does so only when the media focus heavily on it. From this perspective, the "I" (informal) sector simply needs to be for- 
malised, made to pay taxes, given some incentives, brought within the scope of the law and under the control of the justice system and police, if not the military.

Virtually all their policies and "road shows" are aimed at the " $\mathrm{F}$ " (formal) sector, i.e. at mineral/oil and gas/fishery extraction companies, at the new kind of landowners, in celebration of the further division of the land into large estates, at corrupt bankers and property and mega-project developers who, from this discriminatory perspective, are the most worthy sector. This sector has been growing on "autopilot" for three decades in the context of the country's export strategy, even though this has meant - and continues to mean - leaving us without water, forests, biodiversity or people.

\section{Global organised crime}

For at least the last decade, different analysts, reporters and international bodies have been writing about this impact with a focus on the integration of trafficking. See, for example, the works by Loretta Napoleoni, Economía canalla: la nueva realidad del capitalismo ("Rogue economy: the new reality of capitalism") (2011); and by Moisés Naim, Ilícito. Cómo traficantes contrabandistas y piratas están cambiando el mundo ("Illegality. How smugglers and pirates are changing the world") (2006). See also the Gomorra chronicle by the Italian investigative journalist Roberto Saviano (2007) and another more recent article, CeroCeroCero: Cómo la cocaina gobierna el mundo ("ZeroZeroZero: how cocaine rules the world") (2014); or the book by researcher Jean-François Gayraud - essential reading on international organised crime - entitled El G9 de las mafias en el mundo: geopolitica del crimen organizado ("The G9 of the world's mafias: the geopolitics of organised crime") (2009). In 2010, the UN Office on Drugs and Crime published a report entitled The globalization of crime: A transnational organized crime. Threat assessment, which contains an "official" summary of transnationally coordinated crimes in the following table.

Table 2

The globalisation of organised crime in 2009, according to UNODC

\begin{tabular}{|c|c|c|c|c|c|}
\hline \multicolumn{2}{|c|}{$\begin{array}{l}\text { TRANSNATIONAL } \\
\text { ORGANISED CRIME }\end{array}$} & $\begin{array}{l}\text { ESTIMATED } \\
\text { AMOUNT }\end{array}$ & $\begin{array}{c}\text { COST IN } \\
\text { MILLIONS USD }\end{array}$ & $\begin{array}{l}\text { ESTIMATED } \\
\text { TREND }\end{array}$ & POTENTIAL EFFECTS \\
\hline \multicolumn{6}{|c|}{$\begin{array}{l}\text { 1. People } \\
\text { trafficking }\end{array}$} \\
\hline \multicolumn{2}{|c|}{$\begin{array}{l}\text { To Europe for the } \\
\text { purposes of sexual } \\
\text { exploitation }\end{array}$} & $\begin{array}{l}70,000 \text { victims } \\
\text { per year; } 140,000 \\
\text { victims (current) }\end{array}$ & 3,000 (current) & Stable & $\begin{array}{l}\text { Human rights viola- } \\
\text { tions. }\end{array}$ \\
\hline \multicolumn{6}{|c|}{$\begin{array}{l}\text { 2. Illicit migrant } \\
\text { smuggling }\end{array}$} \\
\hline a) & $\begin{array}{l}\text { From Latin } \\
\text { America to } \\
\text { North America }\end{array}$ & $\begin{array}{l}3 \text { million entries } \\
\text { (per year) }\end{array}$ & $\begin{array}{l}\text { 6,600 (trafficker } \\
\text { incomes) }\end{array}$ & Declining & $\begin{array}{l}\text { Illegal immigration, } \\
\text { vulnerability of mi- } \\
\text { grants. }\end{array}$ \\
\hline
\end{tabular}




\begin{tabular}{|c|c|c|c|c|c|}
\hline b) & $\begin{array}{l}\text { From Africa to } \\
\text { Europe }\end{array}$ & $\begin{array}{l}55,000 \text { migrants } \\
\text { per year }\end{array}$ & $\begin{array}{l}150 \text { (trafficker } \\
\text { incomes) }\end{array}$ & Declining & $\begin{array}{l}\text { Illegal immigration, } \\
\text { deaths of migrants. }\end{array}$ \\
\hline 3. & Cocaine & & & & \\
\hline a) & $\begin{array}{l}\text { From the } \\
\text { Andes to } \\
\text { North } \\
\text { America }\end{array}$ & $\begin{array}{l}309 \text { tonnes (at } \\
\text { origin) } \\
196 \text { tonnes (at } \\
\text { destination) }\end{array}$ & $\begin{array}{c}38,000 \\
\text { (at destination) }\end{array}$ & Declining & $\begin{array}{l}\text { Addiction, drug-re- } \\
\text { lated crime, corrup- } \\
\text { tion and violence in } \\
\text { the Andean region, } \\
\text { links with illegal } \\
\text { armed groups, } \\
\text { destabilisation and } \\
\text { corruption in neigh- } \\
\text { bouring states, } \\
\text { Central America } \\
\text { and Mexico }\end{array}$ \\
\hline b) & $\begin{array}{l}\text { From the An- } \\
\text { des to Europe }\end{array}$ & $\begin{array}{l}212 \text { tonnes (at } \\
\text { origin) } \\
124 \text { tonnes (at } \\
\text { destination) }\end{array}$ & $\begin{array}{c}34,000 \\
\text { (at destination) }\end{array}$ & Stable & $\begin{array}{l}\text { Addiction, drug-re- } \\
\text { lated crimes and } \\
\text { violence, destabili- } \\
\text { sation and corrup- } \\
\text { tion in the Andean } \\
\text { countries, Caribbean } \\
\text { and Western Africa. }\end{array}$ \\
\hline 4. & Heroine & & & & \\
\hline a) & $\begin{array}{l}\text { From } \\
\text { Afghanistan } \\
\text { to the Russian } \\
\text { Federation }\end{array}$ & $\begin{array}{l}95 \text { tonnes (at } \\
\text { origin) } \\
70 \text { tonnes (at } \\
\text { destination) }\end{array}$ & $\begin{array}{c}13,000 \\
\text { (at destination) }\end{array}$ & & $\begin{array}{l}\text { Increasing addition, } \\
\text { spread of HIV/AIDS; } \\
\text { increase in organ- } \\
\text { ised crime, funding } \\
\text { of criminals and } \\
\text { insurgents, corrup- } \\
\text { tion. }\end{array}$ \\
\hline b) & $\begin{array}{l}\text { From } \\
\text { Afghanistan } \\
\text { to Europe } \\
\text { (excluding the } \\
\text { Russian } \\
\text { Federation) }\end{array}$ & $\begin{array}{l}140 \text { tonnes (at } \\
\text { origin) } \\
87 \text { tonnes (at } \\
\text { destination) }\end{array}$ & $\begin{array}{c}20,000 \\
\text { (at destination) }\end{array}$ & Stable & $\begin{array}{l}\text { Addiction, increase } \\
\text { in organised crime, } \\
\text { funding of criminals } \\
\text { and insurgents, } \\
\text { corruption. }\end{array}$ \\
\hline 5. & $\begin{array}{l}\text { Illicit gun } \\
\text { running }\end{array}$ & & & & \\
\hline a) & $\begin{array}{l}\text { From the US } \\
\text { to Mexico }\end{array}$ & $\begin{array}{l}20,000 \text { arms, } \\
\text { mainly handguns }\end{array}$ & 20 & Stable & $\begin{array}{l}\text { Increase in the } \\
\text { number of deaths in } \\
\text { Mexican drug cartel } \\
\text { wars }\end{array}$ \\
\hline b) & $\begin{array}{l}\text { From Eastern } \\
\text { Europe to the } \\
\text { world }\end{array}$ & $\begin{array}{l}\text { At least } 40,000 \\
\text { Kalashnikov rifles } \\
\text { in 2007-2008 }\end{array}$ & $\begin{array}{l}\text { At least } 33 \\
\text { (in 2007-2008, } \\
\text { at destination) }\end{array}$ & Declining & $\begin{array}{l}\text { Deaths and insta- } \\
\text { bility. }\end{array}$ \\
\hline 6. & $\begin{array}{l}\text { Illicit natural } \\
\text { resource } \\
\text { trafficking }\end{array}$ & & & & \\
\hline
\end{tabular}




\begin{tabular}{|c|c|c|c|c|c|}
\hline a) & $\begin{array}{l}\text { Wildlife from } \\
\text { Africa and } \\
\text { South-East } \\
\text { Asia to Asia }\end{array}$ & $\begin{array}{l}\text { Ivory: } 75 \text { tonnes } \\
\text { Rhinoceros horn: } \\
800 \mathrm{~kg} \\
\text { Tiger parts: } 150 \\
\text { skins and around } \\
1,500 \text { kgs of bone }\end{array}$ & $\begin{array}{l}\text { Ivory: } \\
62 \text { million. } \\
\text { Rhino horn: } \\
8 \text { million } \\
\text { Tiger parts: } \\
5 \text { million }\end{array}$ & Increasing & $\begin{array}{l}\text { Tigers and black } \\
\text { rhino could be- } \\
\text { come extinct in the } \\
\text { wild; the effects on } \\
\text { South-East Asia's } \\
\text { flora and fauna is } \\
\text { not clearly known, } \\
\text { increase in corrup- } \\
\text { tion and organised } \\
\text { crime. }\end{array}$ \\
\hline b) & $\begin{array}{l}\text { Wood from } \\
\text { South-East } \\
\text { Asia to the Eu- } \\
\text { ropean Union } \\
\text { and Asia }\end{array}$ & $\begin{array}{l}\text { Possibly } 20 \text { million } \\
\text { cubic metres }\end{array}$ & $\begin{array}{c}3,500 \\
\text { (at destination) }\end{array}$ & $\begin{array}{l}\text { Declining } \\
\text { in Indo- } \\
\text { nesia and } \\
\text { Myanmar; } \\
\text { possibly } \\
\text { increasing } \\
\text { in the Peo- } \\
\text { ple's Dem- } \\
\text { ocratic } \\
\text { Republic of } \\
\text { Laos and } \\
\text { Papua New } \\
\text { Guinea }\end{array}$ & $\begin{array}{l}\text { Deforestation, loss } \\
\text { of habitat, loss of } \\
\text { species, climate } \\
\text { change, increase } \\
\text { in rural poverty, } \\
\text { particularly among } \\
\text { indigenous peoples, } \\
\text { illegal migration, } \\
\text { flooding, soil ero- } \\
\text { sion. }\end{array}$ \\
\hline 7. & $\begin{array}{l}\text { Counterfeit } \\
\text { goods }\end{array}$ & & & & \\
\hline a) & $\begin{array}{l}\text { Consumer } \\
\text { goods from } \\
\text { Asia to Europe }\end{array}$ & $\begin{array}{l}\text { Around } 2 \text { billion } \\
\text { articles per year }\end{array}$ & $\begin{array}{c}8,200 \\
\text { (at destination) }\end{array}$ & Increasing & $\begin{array}{l}\text { Decline in safety of } \\
\text { products and ac- } \\
\text { countability, loss of } \\
\text { income. }\end{array}$ \\
\hline b) & $\begin{array}{l}\text { Medicines } \\
\text { from Asia to } \\
\text { South-East } \\
\text { Asia and Africa }\end{array}$ & Billions of doses & $\begin{array}{c}1,600 \\
\text { (at destination) }\end{array}$ & Unknown & $\begin{array}{l}\text { Deaths, drug-resis- } \\
\text { tant pathogens. }\end{array}$ \\
\hline \multirow[t]{2}{*}{8.} & Sea piracy & & & & \\
\hline & $\begin{array}{l}\text { Off the Soma- } \\
\text { lian coast }\end{array}$ & $\begin{array}{l}217 \text { attacks in } \\
2009\end{array}$ & 100 & Increasing & $\begin{array}{l}\text { Difficulties in exer- } \\
\text { cising government } \\
\text { authority, negative } \\
\text { effects on local and } \\
\text { international trade. }\end{array}$ \\
\hline 9. & Cybercrime & & & & \\
\hline a) & Identity theft & $\begin{array}{l}\text { Around } 1.5 \text { million } \\
\text { victims }\end{array}$ & 1,000 & Unknown & $\begin{array}{l}\text { Increase in the cost } \\
\text { of credit, contrac- } \\
\text { tion of the econo- } \\
\text { my, loss of trust in } \\
\text { e-trade. }\end{array}$ \\
\hline b) & $\begin{array}{l}\text { Child } \\
\text { pornography }\end{array}$ & $\begin{array}{l}\text { Around } 50,000 \text { new } \\
\text { images per year }\end{array}$ & 250 & Unknown & Child victimisation. \\
\hline
\end{tabular}

Source: United Nations' Office on Drugs and Crime (UNODC); The globalization of crime: A transnational organized crime. Threat assessment; United Nations publication printed in Austria Sales No. E.10.IV.6 - June 2010 
Francesco Forgione's study entitled "Mafia export: cómo la 'Ndrangheta, la Cosa Nostra y la Camorra han colonizado el mundo" ("Mafia export: how the 'Ndrangheta, the Cosa Nostra and the Camorra have colonised the world") (2010) is also worthy of note. This looks at the three most infamous criminal organisations in Italy and their impact across the five continents. There is also a recent investigation from 2011-2012 on this phenomenon, conducted by Jorge Luis Garay, Luis Jorge Salamanca and Eduardo Salcedo and entitled "Narcotráfico, corrupción y Estados: cómo las redes ilícitas han configurado las instituciones en Colombia, Guatemala y México" ("Drug trafficking, corruption and States: how illegal networks have shaped the institutions of Colombia, Guatemala and Mexico") (2012), which divides these networks into Organised Crime (OC), Systemic Corruption (SC), Capture of the State $(\mathrm{CoS})$ and Co-opted Reshaping of the State (CRoS).

Some years ago, the sociologist and current congressman Manuel Dammert (2001) investigated the "Mafia State" established by Fujimori-Montesinos in Peru. The sociologist Francisco Durand considers that Peru is fractured into formal, informal and criminal (FIC) - a hypothesis we have taken up in this article. For his part, in an essay entitled "La sociedad desviada: Cultura y trasgresión en los valles cocaleros del Perú" ("Deviant society: culture and transgression in the coca growing valleys of Peru") (Proyecto Lab SAC; Lima, 2012), Juan Arroyo Laguna analyses what is known as a "deviant society" in the coca-growing valleys.

\section{Coca growing and rural development}

The most recent official information on the area of the country growing coca crops or its by-products dates from 2015, as published in a 2016 report by UNODC and the National Commission for Development and Life without Drugs (Devida). At the time of writing this text, both institutions should have issued the 2017 report with information updated to 2016, as Colombia and Bolivia did on 18 July this year.

We assume that the delay in issuing the report, as in previous years, is related to the government's need to "massage" the figures. Devida's Executive Director thus stated in March 2017: "In reality, Peru has 55,000 hectares of coca leaf planted, most of it used as an input for the production of cocaine, higher than the 40,300 hectares reported in the last report on Coca Crop Monitoring, published in July 2016 by UNODC". She added that: "What was done in the past was done well but we have adapted the methodology with UN involvement and we are now closer to a far more realistic figure". In addition, Masías, who also led Devida during the first part of Humala's term in office, explained that $93 \%$ of the area that was eradicated in the last two years had been sown with coca once again and indicated that Devida was working on a way of ascertaining the amount of cocaine produced on these 55,000 hectares, "Because the worst thing we can do is bury our head in the sand" (See: http:/ / elcomercio.pe/politica/actualidad/devida-peru-hectareas-coca-pensaba-407795). 
According to the report published by Peru last year, as we can see from Table 3, to December 2015 (UNODC-Devida, 2015):

(1) The area under coca cultivation was estimated at 40,300 hectares, $6.1 \%$ less than the 2014 figure, which was 42,900 ha and which, according to the report, consolidates the downward trend observed since 2011 when 62,500 ha were recorded, coinciding with the implementation of the 2012-2016 National Anti-Drugs Strategy.

(2) The two areas growing the most coca were the Apurímac, Ene and Mantaro River Valley (VRAEM) with 18,333 ha and La Convención and Lares with 10,454 ha, accounting for $71.4 \%$ of the national total. Neither of these areas were subject to eradication.

(3) The Ministry of Agriculture and Irrigation (Minagri) has been promoting a model of voluntary crop substitution in the VRAEM, complementing this with land and air-based prohibition actions on illegal drug trafficking. The model promotes a reduction in the price of the coca leaf, and encourages the population into other development options. As of 31 December 2015, the official figures indicated that 2,224 ha of coca had reverted to legal crops.

(4) In La Convención and Lares, the lack of eradication is based on the fact that this is an area of traditional consumption (chacchado or chewing) but the current production is 15,231 MT of dried leaf, which is more than the 9,000 MT of demand calculated by the National Institute for Statistics and IT (INEI). There is no knowledge or evidence of where this surplus goes.

(5) In 2015, through the Eradication Programme of the Special Project for the Control and Reduction of Illegal Crops in Alto Huallaga (CORAH), the government eliminated 35,868 ha; the highest figure recorded in the country's history. The eradication has resulted in an actual reduction of 2,600 ha and this difference has, in turn, prevented the expansion of the crop to even greater levels.

(6) The tendency to grow coca in Protected Natural Areas (ANP) and in their buffer zones (ZA) varies. Although the area under coca cultivation in ANPs is still not significant, there is concern regarding the ZAs, where control is a more complicated task.

Table 3

Monitoring of coca crops 2015: Key indicators

\begin{tabular}{|l|c|c|c|}
\cline { 2 - 4 } \multicolumn{1}{c|}{} & $\mathbf{2 0 1 4}$ & Variation in \% & $\mathbf{2 0 1 5}$ \\
\hline $\begin{array}{l}\text { Net area of coca crops, calcu- } \\
\text { lated as of 31 December }\end{array}$ & $42,900 \mathrm{ha}$ & $-6.1 \%$ & $40,300 \mathrm{ha}^{2}$ \\
\hline $\begin{array}{l}\text { Average yield of sun-dried } \\
\text { coca leaf }\end{array}$ & $2,349 \mathrm{~kg} / \mathrm{ha}$ & - & $2,39 \mathrm{~kg} / \mathrm{ha}$ \\
\hline
\end{tabular}




\begin{tabular}{|l|c|c|c|}
\hline $\begin{array}{l}\text { Potential production of sun- } \\
\text { dried coca leaf }\end{array}$ & 100,840 MT & $-45 . \%$ & $96,304 \mathrm{MT}^{4}$ \\
\hline $\begin{array}{l}\text { Potential production of } \\
\text { cocaine hydrochloride }\end{array}$ & No data & - & No data $^{5}$ \\
\hline $\begin{array}{l}\text { Average arithmetic price } \\
\text { of sun-dried coca leaf for a } \\
\text { smallholder }\end{array}$ & USD 4.3/kg & $-9.3 \%$ & USD 3.9/kg \\
\hline $\begin{array}{l}\text { Average weighted price of } \\
\text { sun-dried coca leaf for a } \\
\text { smallholder }\end{array}$ & USD 3.7/kg & $-13.5 \%$ & USD3.2/kg \\
\hline $\begin{array}{l}\text { Potential value of sun-dried } \\
\text { coca leaf for smallholders }\end{array}$ & USD 434 million & $-13.6 \%$ & USD 375 \\
\hline Average price of basic paste & USD $843 / \mathrm{kg}$ & $-11.6 \%$ & USD 745/kg \\
\hline $\begin{array}{l}\text { Average price of cocaine } \\
\text { hydrochloride }\end{array}$ & USD 1,178/kg & $-3 / 8 \%$ & USD 1,133/kg \\
\hline $\begin{array}{l}\text { Coca crop eradication report- } \\
\text { ed by the CORAH project }\end{array}$ & $31,205 \mathrm{ha}$ & $-14.9 \%$ & $35,868, \mathrm{ha}$ \\
\hline $\begin{array}{l}\text { Basic paste eradication } \\
\text { reported by the Peruvian } \\
\text { Police }\end{array}$ & $11,116 \mathrm{~kg}$ & $-4 / 5 \%$ & $11,621 \mathrm{~kg}$ \\
\hline $\begin{array}{l}\text { Seizure of cocaine hydrochlo- } \\
\text { ride reported by the Peruvian } \\
\text { Police }\end{array}$ & $18,699 \mathrm{~kg}$ & $-54 / 8 \%$ & $8,446 \mathrm{~kg}$ \\
\hline
\end{tabular}

1. Area of coca crops calculated to 31 December from an analysis of satellite images, after the areas eradicated by the CORAH project had been discounted. Eradication data to 31 December 2015 was included in the analysis.

2. The final figure also reflects the reduction in coca area corresponding to the eradication conducted by the coca farmers in the VRAEM, according to Government of Peru reports.

3. The differences between years are not real changes measured in the field but are rather caused by changes in the weighting of historical yield figures versus the difference in areas growing coca. See the methodology for further explanation.

4. Potential production (minimum) that does not include the eradicated areas and others that were productive during the evaluation period: see evaluation and methodology chapters). It includes 9,000 MT of coca leaf for traditional consumption, as reported in the "National survey on traditional consumption of coca leaf in the home", INEI 2004, p.39.

5. Not known. The study to determine coca-cocaine conversion factors has not yet been conducted.

(7) The data indicates that, in 2015, coca crops expanded by 134 ha in the National Protected Areas while in the ZA this figure reached 6,614 ha, both in the Bahuaja Sonene National Park (Puno and Madre de Dios) - basically in the coca 
growing areas of Inambari-Tambopata and San Gabán -, in the Otishi National Park (Junín and Cusco) and in the Tingo María National Park.

(8) The report establishes that these areas need to be conserved through responsible and sustainable resource development and exploitation strategies, resulting in intersectoral prevention, control and development activities, promoting public and/or private investment with the people's participation.

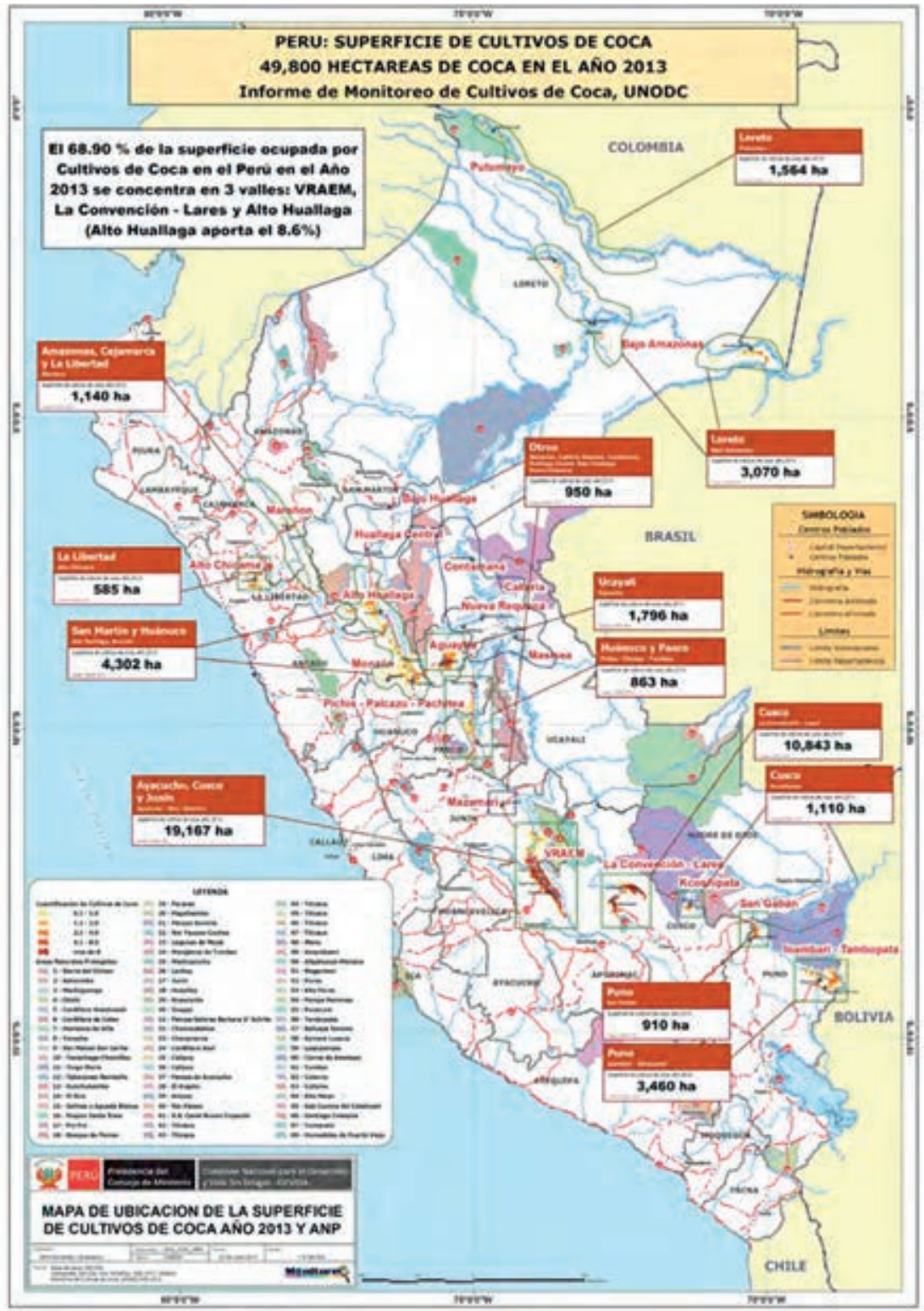

Source: MININTER-CORAH-CADA 2010 Map of the location of coca leaf growing areas in Peru. 
The document notes: "As of 2015, illegal mining activity had covered 1,032 ha and was being conducted alongside coca growing but was also encouraging and promoting other crimes, such as people trafficking and serious environmental damage, including deforestation and forest degradation. This also caused health issues, due to the indiscriminate use of mercury, cyanide and other chemicals." (UNODC-DEVIDA, 2015)

\section{The Amazonian Trapezium and the MAP Zone}

Peru has four "triple borders" all of which create serious problems for the safety of the different demographic groups living within the country: indigenous peoples, peasant farmers, forest dwellers, riverine settlers and urban populations. These borders are: the Amazonian Trapezium bordering Brazil and Colombia; the MAP (Madre de Dios, Acre and Pando) Zone bordering Brazil and Bolivia; the Güeppí Reserved Zone bordering Ecuador and Colombia; and the Línea de la Concordia bordering Chile and Bolivia. Apart from the MAP Zone, the other three border areas are highly militarised or with police garrisons. This is due to the insecurity caused by a lack of State presence, a lack of organised civil society, the inexistence of political parties, the weakness of civic movements and the persistence of various kinds of crime that have developed in recent decades, all of which live alongside each other and feed off each other.

In general, and above all, in border areas overlooked by the centres of power, a focus on the concept of national security, i.e. a "war" against these crimes, does not help to mitigate the problems but instead disperses them and turns them into a "moving target". A human security strategy to combat neglect and distance, accompanied by one-off operational intelligence and police actions, would seem more appropriate. These are cross border societies forgotten by the State, politicians, society and the formal markets. Informal and illicit activities are how these societies manage to combat this neglect.

Let us now take a look at the main demographic features of Peru's triple-border areas from a human and civic security perspective:

\section{Amazonian Trapezium}

Highly militarised and sparsely populated (Colombia 30,000 people, Brazil 20,000 and Peru 2,000) with indigenous peoples and citizens being negatively affected by the "Plan Colombia" aimed at combatting the FARC guerrilla - Frente 53 -, with the smuggling of goods, illegal logging and fishing, coca growing, and a transiting illicit drug trade. Civic State institutions are present in Leticia and Tabatinga but non-existent in Santa Rosa. Indigenous peoples are weakly organised in Leticia and Tabatinga but non-existent in Santa Rosa, Caballococha and El Estrecho, the capital of the Putumayo River on the Peruvian side. 


\section{Güeppí Reserved Zone}

A sparsely populated militarised zone (Ecuador 2,000, Colombia 7,000 and Peru 1,000 people). Indigenous peoples harassed by the "Plan Colombia" and the FARC, the oil transnationals in Ecuador and mining companies in Peru. Little presence of civic State bodies and almost non-existent organised civil society. Nevertheless, the cross border indigenous peoples have managed to gain three Protected Natural Areas from the government: the Güeppí Reserved Zone in Peru, La Paya National Park in Colombia and the Cuyabeno National Park in Ecuador.

\section{MAP Zone}

Not yet militarised, with a significant population in comparison to the other "Triple Borders" (Pando 52,000, Acre 750,000 and Madre de Dios 120,000), and with organised indigenous peoples, riverine settlers, peasant farmers and rural workers, plus a notable presence of State and local government institutions and a strong civil society presence. This civil society presence is partially represented in the MAP Initiative, a coordination of academics, government officials, NGOs and leaders of grassroots social organisations.

\section{Línea de la Concordia}

A militarised zone, largely desert, with very low permanent population (Bolivia 2,000, Chile 2,000 and Peru 1,000), primarily Bolivian Quechua-Aymara inhabitants working in informal cross border trade (smuggling), and being harassed by soldiers and police. There is a presence of illicit drug trafficking and an absence of State bodies or organised civil society.

These geographical areas and their environments have the following basic features:

1) They are being seriously affected by illegal activities and organised crime; for example crop growing for drugs - primarily coca and poppy -, illegal logging, informal mining, trafficking of endangered species, arms trafficking, smuggling and people trafficking.

2) They are highly vulnerable to the impacts of climate change, deforestation, the disappearance of plant and animal species and constant violations of the native indigenous, peasant, forest and urban inhabitants' territorial and cultural rights.

3) They contain biological corridors of immeasurable wealth and cross border Protected Natural Areas, in addition to being major sources of freshwater for human consumption, carbon sinks and a source of enormous traditional knowledge.

4) Highway megaprojects are being or will be built - IIRSA North, Centre and South; as well as energy projects - mining, gas and oil; agribusiness - soya biotrade, biofuel, sugarcane ethanol and large-scale cattle rearing, all of which are affecting the biodiversity, food security, cultures and sustainable economies of a major part of the Amazon basin. 
5) Finally, they are significantly militarised with police garrisons and a proliferation of different forms of public and private corruption, organised crime and generally anti-democratic forms of social and political relations.

Three of these triple-border areas are militarised, neglected by successive governments and with limited rights for indigenous peoples and citizens generally. The MAP Zone is the exception and must not change, although the three governments have held coordination meetings between their armed and police forces to address the issue of the ever greater presence of the illicit drug trade as a consequence of misguided drug policies, transposed from the "war on drugs" imposed by the US government.

\section{Criminal cross border links}

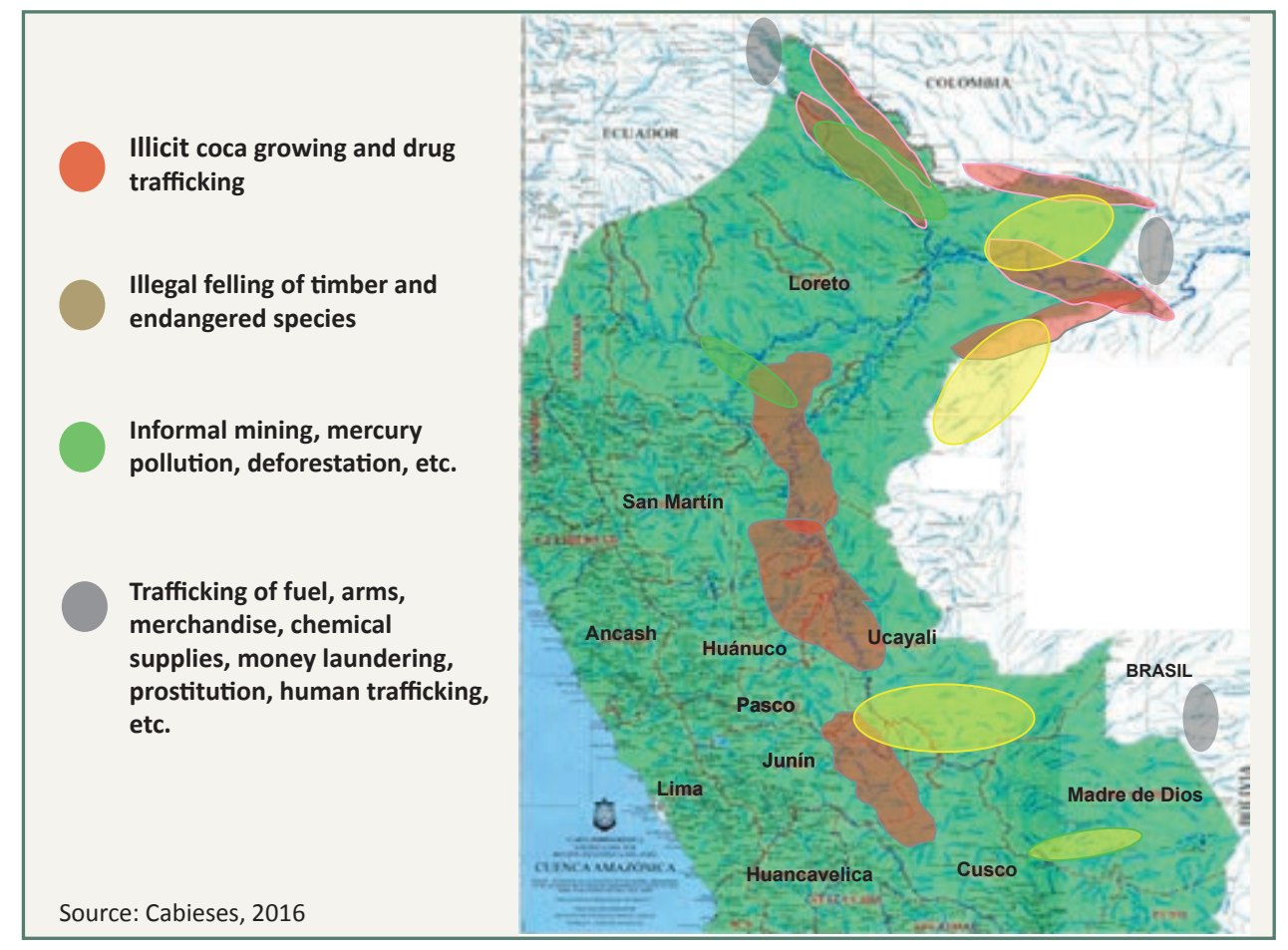

\section{Traditional and beneficial industrial uses of coca}

In terms of these purposes, and how they relate to other illicit uses, in the case of the Amazonian peoples of the Putumayo River in the north-east of the country, we were informed during an interview with Huitoto and Ocaina chiefs in October 2002 in "El Estrecho" that all the communities have "a number of [coca] plants" because "our creator gave them to us, tobacco too, which complements coca and which we call ampiri". 
They added that "coca and tobacco are people and should be respected as such", although they know that "others came and misused them, both coca and tobacco, they turned them into a commodity". One Ocaina chief informed us that there were three types of coca in Putumayo and that they were used both for traditional consumption in the form of "mambeo" (they don't know the "picchado" ${ }^{\prime \prime}$ method) and/or as a source of income for peasant families. According to this informant, every Huitoto or Bora inhabitant has 30 or 40 coca plants for personal and family consumption. They also use coca in the mingas or communal work parties.

The kinds of coca that are grown are: "Coca Huitota", which is harvested every 45 days and which has more "flour" (paste) - albeit less than "Coca Tingo" - and for which a harvest of $12 \mathrm{~kg}$ gives 35 to $40 \mathrm{~g}$ of paste meaning that it is used solely to "trade" with the "chatarreros", Colombian barges that ply the Putumayo River; "Coca Bora", which is also harvested every 45 days, and which has more "oil" and is therefore used solely for "mambeo"; if processed, it gives between 18 and $20 \mathrm{~g}$ of paste per harvest; and "Coca Tingo", which is harvested every 90 days and which has far more "flour" (paste) than the other two, and so is not used for "mambeo" because between 45 to $50 \mathrm{~g}$ of paste can be obtained per harvest. Although its "yield" is less, it is used solely to produce basic cocaine paste because it has "a lot of leaves".

During the workshops, an interesting debate arose regarding the use of coca. While a Peruvian Bora chief called for "the government to legalise coca and enable them to sell it to the 'chatarreros'," a Colombian Huitoto explained that coca should be respected within the context of its traditional use and "should never be legalised" and that "selling it to the 'chatarreros' would be disrespectful as we all know that this coca goes to the drug traffickers". A Peruvian leader with a Huitota mother and an Ocaina father was of the same opinion as the Colombian, saying, "I don't 'mambeo' anymore but my mother does and I don't think coca should be legalised," although he clarified, "the government should help us with alternative markets and products".

A Huitoto myth goes as follows: "In this history of coca there are two paths, as always: good and bad ... Storytellers have said that coca is in some way related to wisdom, that it comes from God. If it is abused, if it is used badly, this aspect is lost... God put the plant at the service of mankind, not for evil nor for it to be abused. Those who handle it badly will perish in evil. Those who handle it well will prosper in good. Using coca properly calms the intelligence and does not leave a person foolish. It makes them serious, kind, progressive, as our ancestors clearly understood." (Kuyoteka, 1997: 188-189).

4. A regional term from Colombia and the Peruvian border to refer to a method whereby coca leaf is toasted and then crushed into a powder and mixed with the ash of Cecropia tree leaves before being used. Common among the Bora, Huitoto and Ocaina.

5. A method that involves masticating or chewing dried coca leaves into a ball between the gum and the cheek to extract the active substances. 
In 1995 I wrote a report entitled "Comercialización de la coca: posibilidades y propuestas" ("The Commercialisation of Coca: possibilities and proposals") (Cabieses, 1996) where I established: the dimensions of the traditional consumption of the coca leaf in Bolivia, Colombia, Peru and other Andean/Amazonian countries; the problems with the so-called alternative development in relation to coca leaf growing; and the beneficial commercialisation and industrialisation of the coca leaf. Twenty years on, I maintain that coca growing is of disproportionate significance to Andean/Amazonian countries, as seen in the production of cocaine for non-medical uses and for illegal drug trafficking. It is therefore necessary to voluntarily reduce these crops, through rural development and without implementing any kind of eradication or fumigation policy. With the support of the State and the private sector, the crops should be reduced to what is strictly essential for traditional consumption and its beneficial industrialisation.

I have and continue to maintain that although it is right and absolutely necessary to nationally and internationally defend the beneficial use of the coca leaf, both traditional and industrial, the proposal for a beneficial industrialisation of coca should not be promoted among farmers as a basis for resolving their income and poverty problems because of the agroecological, socioeconomic and cultural effects it would have on the areas where this plant is grown. It would be environmental, economic and cultural suicide to propose a strategy for prioritising coca crops to these farmers, or indeed any other export crop promoted as part of the so-called alternative development, in areas with such severe agroecological and forest fragility as the high forests of Peru.

The strategy we are proposing is one of sustainable and lasting comprehensive rural development with coca (DRIS-C), which supports an ecological, economic, social and political process for the coca growing areas and their environs - including the migrant labour-producing and poorer highlands, - a process that includes respect for the growing of the coca leaf for its traditional and modern use in the form of industrial products based on this and other plants. This is a strategy that forms part of a model of alternative development to combat poverty, coming from the bottom up, from within, independent, self-focused, aimed at local markets, with the full participation of the population and with respect for the cultural uses of coca production and consumption. This new economy and alternative culture to that of poverty would be based on agricultural and agro industrial diversification, with small areas, as necessary, for coca growing. I have been proposing a strategy for several years that is focused around the following five points:

1) Coca leaf is complex and has three dichotomies: coca is not cocaine (although it contains it), coca producers are not criminals and coca consumers are not drug addicts. Coca also has at least six characteristics not just one: it is a key element of Andean/Amazonian cultural identity; it is socially and customarily cohesive; it is a social lubricant and provides energy for communal work and long journeys; it is the spending and investment currency of the peasant economy; it is the raw 
material for beneficial processing and industrialisation; and it is the raw material for drug production. The latter must be controlled, both socially and by the State, to combat its illegal trafficking.

2) There needs to be an international re-assessment of coca, by removing it from the UN's Schedule One drugs in order to promote external markets, and by internally respecting and promoting its traditional and beneficial industrial use. For both endeavours, there is a need to conduct serious studies into its current cultivation, production and consumption, as well as its future possible beneficial industrial possibilities.

3) Given that there is currently a significant surplus of coca leaf, it is essential to limit and reduce its cultivation and production to what is strictly necessary for traditional consumption and beneficial industrial processing and, naturally, to respect the amount of cocaine needed for therapeutic uses. This means rejecting the "zero coca and coca grower" strategy but promoting a "zero drugs trafficking and illegal cocaine" one.

4) To limit coca growing, sustainable and lasting comprehensive rural development programmes must be promoted with the active participation of famers and local authorities. These programmes must, however, be aimed at building local, regional and national markets and not at producing substitute export products for Free Trade Agreements (FTA), because the high and low Amazon areas are not suitable for export agriculture under the current conditions of globalisation due to their ecological and environmental fragility.

5) The Andean countries must discuss, approve and promote a State policy on the coca leaf and drugs, and not just on drugs with coca being subjected to fumigation and elimination. The US and the specialist UN agencies' policy must not be promoted as it is ineffective and is actually a strategy for controlling the natural resources of the Amazon: gas, oil, water, timber, biogenetic resources, active ingredients of plants and animals, indigenous cultures, ancestral knowledge and so on.

In conclusion, I am in favour of a national and international re-assessment of the coca leaf for its traditional and beneficial industrial uses, including the sale and export of industrial by-products and an expansion of the therapeutic use of cocaine. At the same time, however, I am equally against hiding the immense quantity of coca crops grown for illicit purposes, or the enormous perverse anti-cultural, anti-democratic and criminal business that currently exists with regard to the surplus behind the argument of the "industrialisation of coca", or, worse still, the "war on drugs". This would be a multiple crop and multiple activity model combining different ecological floors, primarily for the domestic market plus a limited export market; if there were to be advantages in this, they would encompass a balanced relationship with nature. The model can be summarised in the following eight points:

1) Rejection of the "war on drugs" through a principle of sovereignty and because it has been ineffective in reducing drug trafficking and abusive drug consumption. 
2) Defence of the production, traditional consumption and legal marketing of the coca leaf.

3) National and international actions to re-assess and decriminalise the coca leaf.

4) Beneficial industrialisation of the coca leaf and promotion of scientific research and of alternative products for internal consumption and export.

5) Programmes of voluntary substitution of surplus crops with the social organisations involved in decision-making.

6) Promotion of sustainable comprehensive rural development projects involving peasant organisations in current coca growing areas and in the areas that are creating the migrant labour that arrives there, supplementing the projects with coca growing.

7) Substantial changes in macroeconomic strategies and policies in favour of agricultural production, rebuilding the food system, promoting production chains with safe and fair markets, rational use of the forests and their biodiversity, binding ecological/economic zonification, and export of competitive products, prioritising social issues.

8) Information, education and prevention of drug use programmes in low-income neighbourhoods and rural towns with high-risk populations, with the involvement of social organisations.

Some of the syndromes that we are seeking to overcome with the DRIS-C strategy are the following:

1) "Public works syndrome", prioritising cement, sand and iron for public works rather than focusing on management and training: there is a great deal of hardware but very little software.

2) "Plant construction syndrome" where processing plants are built but end up as white elephants due to a lack of technical assistance or loans for working capital.

3) "Export syndrome" or the almost exclusive promotion of agri-export products to replace coca crops without considering potential local, regional and national markets.

4) "Model syndrome" in which a template or package of similar measures is imposed instead of respecting the different features of each area in which coca is being grown.

5) "Welfare syndrome" or an addiction to going cap in hand to request public and international cooperation funds with no prior plans or strategic planning.

6) "Money syndrome" or requesting more funds on the premise that the problem can be solved with more money instead of appropriate strategies.

7) "Secrecy syndrome" or a lack of transparency and democracy when making and carrying out project decisions.

8) "Failure syndrome" or an addiction to repeating the same errors and therefore continually failing.

It was due to such syndromes that Dante Deza, a peasant leader from the Upper Inambari, in the Puno forests, stated the following in 1998, when I was work- 
ing in his area promoting a DRIS-C type project with German cooperation (GTZ, now GIZ): "For us, alternative development is when we ask for salt to make salted meat, but instead they give us detergent, saying we don't know how to wash our clothes because we wash them on a stone in the river; when we ask for seeds and credit to plant but they offer us cement and stones to build; when we ask for technical assistance and agrarian training but they give us participatory workshops to obtain information from and about us; when we ask for information on international funds and they say, we can't tell you because it's a secret."

In a similar vein, Azucena Veramendi, Mayor of Cuyaco in Valle del Monzón, Huánuco, states the following: "For us, alternative development means them planting the projects on a table, growing them on a blackboard, harvesting them on a computer and selling them on TV adverts. Alternative development is a $4 \times 4$, i.e. four consultants drafting proposals within four walls."

\section{The Amazon Basin and the Protected National Areas}

The Amazon basin is the largest rainforest on earth and an important source of natural resources and environmental services. It covers an area of 8.2 million square kilometres, including large parts of Bolivia, Brazil, Colombia, Ecuador, Guyana, Peru, Surinam and Venezuela (PNUMA-OTCA-UP, 2009).

UNESCO has established biosphere reserves in the forests of Peru and elsewhere, as in the Manu Biosphere Reserve in Peru or the Yasuní Biosphere Reserve in Ecuador; they form part of humanity's natural heritage as they represent the different habitats on the planet. These reserves have been designed, in some cases, as areas for experimentation, perfecting and demonstrating the union between the conservation of biological diversity and socioeconomic development as well as the maintenance of associated cultural values.

Each country manages and develops strategies for safeguarding these areas, which fall under their own systems of Protected Natural Areas. However, State actions are insufficient due to budget limitations and a lack of defined environmental policies along with the anthropic pressures of recent years, all of which have resulted in a heavy loss of forested areas.

Deforestation in the buffer zones of the biosphere reserves has increased in recent years. For example, in the buffer zone of the Manu National Park, ${ }^{6}$ which covered an area of one million hectares in 2005, some 55,477 ha has now been deforested. In the buffer zone of the Yasuní National Park, ${ }^{7}$ with an area of 656,000 ha, a deforestation rate of 40,000 ha/ year has been recorded.

Degradation can be defined as a decline in forest functions, for example, the forest's function as a carbon store and sink, or its capacity to produce environ-

6. The Manu National Park covers 1,600,000 ha and the Biosphere Reserve 3,000,000 ha.

7. The Yasuní National Park covers an area of 982,000 ha and the Biosphere Reserve 2,500,000 ha. 
mental goods and services, as well as its intrinsic biological diversity. The causes of degradation are attributable to humankind, even when the land is still maintained as a forest. The degradation of the buffer zones has not been assessed but we know there have been losses of forest species due to selective felling or other activities by settlers, impairing the capacity of the forests and their biodiversity.

In these Andean / Amazonian areas, indigenous peoples live alongside riverine settlers, old and new, mostly from the highlands, who put pressure on the natural resources, affecting the biodiversity and environment generally, and thereby contributing to climate change and global warming.

The extreme poverty of the native communities and settlers, along with road, energy and production megaprojects that are being promoted by governments and the private sector, without the necessary environmental impact assessments, are the two main sources of pressure on the forest resources. They create a vicious circle of deforestation-poverty-resource overexploitation-megaprojects-human trafficking-more poverty. Human trafficking and the development of unlawful activities or activities for illicit purposes is a phenomenon that is still localised and small but growing in some Andean/Amazonian regions. Deforestation is caused by extraction, hydrocarbon and monocropping activities in the Amazonian tropical rainforest, small-scale artisanal and illegal mining.

\section{A proposal based around gastronomy}

President Pedro Pablo Kuczynski and his "high-end" technocrats are incapable of considering, for example, the "G" (gastronomic) sector that is being promoted by Gastón Acurio and his chefs. This is perhaps the sector with the greatest prospects and likelihood of sustainability for Peru at national and international level. In this model, the gastronomic/agroforestry / fishery sectors work in coordination with sustainable tourism and biodiversity and with the rational use of resources and peasant family production, in ways that Acurio and his gurus are seeking to establish.

In three notable books, the Peruvian lawyer, historian and scientific researcher Santiago Erik Antúnez de Mayolo Rynning (2011), the neurosurgeon, historian and founder of Peru's Museo de la Nación, Fernando Cabieses Molina (2004), the German archaeologist and historian, Hans Hork Heimer (1958 and 1973), and also the archaeologist, Elmo León Canales (2013), have all borne witness to the contributions of pre-Hispanic agriculture, fishing, animal rearing and cooking to Peruvian and world cuisine. The aforementioned were among some of the scientific precursors to the current chefs and popularisers of Peruvian gastronomy who have launched the proposal for a Chef-Peasant Farmer Alliance. The basis for this gastronomic revolution is, however, the biodiversity and multicultural nature of our variegated territory and its peoples.

As the former Minister of Agriculture and director of the Peruvian Gastronomy Society (APEGA), Luis Ginocchio, argues (2012: p. 21): “This universe of Pe- 
ruvians comprises millions of men and women using and conserving the national biodiversity to cultivate, rear and fish the ingredients that chefs - the cornerstone in disseminating our gastronomy - place on the tables of their restaurants both in Peru and elsewhere". With regard to this Chef-Peasant Farmer Alliance, Ginocchio writes that this "is the result, in essence, of an unparalleled combination, an unprecedented meeting of desires to move forward together, to share challenges and achievements with related industries in the search for flavour, identity and profitability".

Peruvian chef Gastón Acurio goes further, writing: "A unique biodiversity, full of thousands of new products, a cultural diversity that gives them added value, an age-old history and mysticism that adds magic and even more value, and immense underlying social and environmental challenges which, for today's consumer, adds value at the time of purchase. In other words, we have everything. We have everything to be able to conquer the world with a range of food, textile, cleaning and personal care and well-being products that represent a great "Made in Peru" brand that will meet all consumer expectations, both present and especially future; and with these we will transform the lives of our fellow citizens, many of whom now live in poverty, our brothers and sisters of the rural world, turning them into Peruvian citizens who are a part of the country's development and prosperity".

In his most recent article, Gastón Acurio argues that: "Millions of fellow Peruvians now feel their economic opportunities have been undermined, as has their ancestral world vision, the environment that they have looked after for years, their right to be happy as they understand happiness, by those who believe that agricultural commodities such as soya or maize are Peru's economic panacea" (See: http:/ /elcomercio.pe/ opinion/ columnistas/somos-libres-seamoslo-siempre-gaston-acurio-noticia-1717708).

In sum, the geography, ecology, hydrology, climate, cultures and demography of the country demand that we address its specific diversity and variability, and focus on converting it into a gastronomic power.

\section{EEDISS and REDD+ Proposal}

The strategic proposal should be focused on the need to promote programmes and not "projects" - of Sustainable and Lasting Comprehensive Eco-Ethnodevelopment (EEDISS), developed by the native indigenous communities of the Andean/Amazonian regions themselves. It would mean comprehensive, endogenous, sustainable development specific to a particular people - in our case a number of peoples in the same area - in harmony with their ecosystem in order to preserve their life and culture, as well as the survival of ecosystems, within the historic changes, continuities and transformations that are occurring.

The programme should comprise a number of social, institutional and technical/productive projects with the proposal's strategic focus being on the forest conservation and protection programmes that local and regional governments need to promote in relation to the REDD+ (Reducing Emissions from Deforestation 
and Forest Degradation) mechanisms being discussed nationally and internationally. It is commonplace among those discussing these issues that development, based on a dynamic and open concept of human rights, requires an in-depth review of the multiple uses the term has had. There are hundreds of books discussing this issue, one of them by Eduardo Gudynas (2004) of the Latin American Social Ecology Centre (CLAES).

According to Rodolfo Stavenhagen (no date): “...for the indigenous peoples, development above all means satisfying human needs that have largely been denied to them, along with an equitable distribution of the resources and benefits of growth (...) Combatting structural racism consequently becomes a struggle for survival and equity in the cultural and social contexts specific to indigenous peoples. Framing the problem of development from this perspective has led to concepts such as self-development and ethno-development, or development with identity, which is now being promoted by some governments, multilateral agencies and non-governmental organisations".

This concept was already being discussed and its practical application considered at the start of the 1980s (Bonfil Batalla, 1982) and, in recent years, it has even been adopted by the World Bank (Griffiths, 2005) and is being applied in the Andean countries. It was also the hypothesis put forward by the economist Hernando De Soto in a study published following the Bagua massacre of June 2009 (De Soto, 2010). Nevertheless, what we are proposing here has little in common with that proposed by the World Bank or De Soto.

Firstly, the Andean-Amazonian native communities must, as a priority, implement management strategies for their living space aimed at ensuring the food autonomy and security of each community's families. The World Bank's priority, in contrast, is focused on creating a cash income.

Secondly, the idea of own culture is linked to the notion of indigenous autonomy. The Bank, however, is seeking full and total integration into the global market, dominated by financial and industrial multinationals.

Thirdly, for De Soto the issue of Amazonian peoples - as previously with the informal sector and then the coca growers - can be summarised as the need for individual property titles, a reduced role for the State and the elimination of communal relationships. For indigenous peoples, in addition to respect, the issue is rather one of territory in harmonious relationship with nature, the presence of a plurinational State and respect for communal relationships.

Fourthly, the native Amazonian peoples, who have traditionally been forgotten, have begun to be more visible and have mobilised against government policies and decrees for just one reason: respect. The World Bank and De Soto use the indigenous peoples rather than respect them, in at least five different ways:

1) For being different through their unity in Andean-Amazonian diversity, their multilingualism, multiculturality, multinationality and their right to be different. 
2) Because land as a resource is not the same as land as territory which, for indigenous peoples, includes the subsoil, soil and air. The forests and subsoil resources do not "belong to all Peruvians" as the Constitution and governments state but to the human beings living in and on them because the territory is a part of them, of their very bodies. Extracting oil, cutting trees and selling carbon credits is like tearing out a part of their heart and soul.

3) Because they should be consulted voluntarily in a free prior, informed and binding manner, with a right of veto, in application of the Constitution and international agreements, particularly ILO 169.

4) By insulting them and accusing them of being a "dog in a manger", calling them second-class citizens, unpatriotic, narco-blockers ${ }^{8}$ and terrorists, as the government and oil and mining companies did in 2008 and 2009.

5) Because they have their own model of development, community relations and reciprocity, based on a harmonious relationship with Mother Nature, rather than being extractivist and aimed at local markets; in sum their own eco-ethnodevelopment, built on their own terms and rhythms, and not on those imposed by the market.

Sustainable and lasting comprehensive eco-ethnodevelopment (EEDISS) prioritises collective rights without overlooking individual ones. It is based on a balance between these two sets of rights and customary rights. EEDISS is dynamic, not static; it has its own timescales, in line with the opportunities and enormous limitations and failures of the "Western model" of "developmental growth". The clear decadence of the current model, as noted in the six crises above, has opened a path to eco-ethnodevelopmental proposals that are increasingly gaining ground. From the trenches of small farming communities, it has now been made formally explicit in the UN Declaration on the Rights of Indigenous Peoples.

In addition, great progress has been made in the texts of Bolivia's and Ecuador's constitutions, ratified in referenda by a clear majority of their peoples. The fact that a State is recognised as plurinational, in which representatives can be elected by habit and custom, and in which legal pluralism is recognised, is an area of major progress that would have been unthinkable 10 years ago.

The proposed programme would require funding in the form of donations and State subsidies for the first five years- even though this sounds bad in a neoliberal context -, until the necessary institutional structure has been established to: (a) establish socially and culturally profitable businesses with a foothold in local, regional and international markets, based around the sustainable management of forest resources, small-scale organic agriculture, indigenous handicrafts, ecotourism and ecological mining, where appropriate; and (b) qualify for the purchase / sale of credits or carbon credits in a voluntary and / or regulated context.

8. "Narcobloqueadores" - this is the derogatory term used by governments and the US Embassy to refer to coca growers who organise actions against the policy of compulsory eradication of the coca leaf. 
The programme should encompass social/institutional projects and technical/productive activities, both focused strategically on the REDD+ programme:

1) Social projects aimed at meeting the educational, living, health/nutrition and food sustainability needs of native indigenous communities, with their close involvement.

2) Institutional projects focused on strengthening the communities' direct capacities to promote the programme as a whole, with a view to a REDD mechanism and the relationships that will be needed with institutions and businesses outside of their territorial environment.

3) Technical/productive activities aimed at implementing profitable activities, based on limited local resources and on native cultures, in their capacity as gatherers, hunters and fishers.

\section{By way of conclusion}

According to the Aidesep-FPP study, the main deforestation trends in Peru, past and present, are as follows:

- As of 2014, between $8,900,000$ and 10,500,000 million hectares of forest had been felled, approximately $11 \%$ to $13 \%$ of the primary forest. Most of this deforestation can be attributed directly to State and corporate policies that have encouraged the settlement and agricultural development of the Amazon: roads, credit, etc. Most of this deforestation has taken place within a $20 \mathrm{~km}$ radius of the main highways.

- Historic deforestation in Peru has been relatively low compared to other Amazonian countries; less than $0.2 \%$, with an annual average of 123,000 ha between 2001-2012. However, there are indications that this rate may have increased to as much as 250,000 ha / year since 2012.

- With annual deforestation rates of only $0.1 \%$ on lands recognised to the native communities, indigenous territories form an important barrier to deforestation: 75\% of deforestation in Peru has taken place outside of indigenous territories and Protected Natural Areas.

- Commercial agriculture, legal and illegal gold mining and oil palm plantations have become the main direct causes of deforestation, representing more than $20 \%$ of annual deforestation in 2013. Unbridled illegal logging is one of the main causes of forest degradation, which then speeds up subsequent deforestation: $80 \%$ of timber exported is felled illegally.

- The extreme degradation of the forests, their biodiversity and associated ecosystems is also caused by oil and gas spills: oil and gas concessions covered more than $80 \%$ of the Peruvian Amazon in 2012.

- The underlying drivers of deforestation in Peru are the large investment projects in agroindustry; oil palm, timber, mining, dams, hydrocarbons and highways which, together, map out a predatory vision of the Amazon. 
- Endemic corruption, the presence of criminal organisations and only incipient governance in the forest and mining sector all enable high levels of illicit activity. In Madre de Dios, $97 \%$ of the gold produced is done so illegally.

- Currently, 15 million ha, or 20\% of the area of the Peruvian Amazon, enjoys a certain level of recognition as indigenous lands, while another 20 million is subject to customary systems albeit without recognition.

- The criminalisation of indigenous self-determination and of its application when defending rights and territories. In many cases, indigenous demands and complaints of illegal activities fall on deaf ears in the State.

The State is displaying levels of tolerance and apathy in relation to the intimidation, persecution and murder of indigenous leaders by economic interests, as well as in relation to the extractive companies, which are encouraging divisions within the communities and their organisations by means of threats, manipulation and intimidation. Deforestation rates are expected to rise significantly in Peru in the near future due to the irresponsible dogma of imposing ever more irrational and greater economic growth at the cost of the Amazon's equilibrium, along with increased investment in energy and infrastructure projects aimed at meeting national, regional and global demand for energy and consumer products. The illegal/ legal exploitation of gold, expansion of oil palm plantations and construction of more than 50 large-scale dams all represent major threats to the Peruvian Amazon in the immediate future.

I shall end by quoting the Amazonian writer, Róger Rumrrill, who stated the following in his most recent book: "As in the $16^{\text {th }}, 17^{\text {th }}$ and $18^{\text {th }}$ centuries, the Amazon has once more become a Utopia, this time due to its biodiversity and freshwater, energy and also food reserves, all of which could be managed, processed and exploited sustainably through good governance, through indigenous science and technology, culture, education, knowledge, science and wisdom, in particular, and by Amazonian men and women generally, and their extraordinary capacity to adapt to the radical transformations that the world recession and global warming are causing on Planet Earth" (Rumrrill, 2017: 39).

\section{BIBLIOGRAPHY}

ACURIO, Gastón (2016). Sazón en acción: algunas recetas para el Perú que queremos. Lima, July 2016. AIDESEP-FPP (Valqui, Michael, Feather, Conrad and Espinoza Llanos, Roberto) (2014). Haciendo visible lo invisible: Perspectivas indigenas sobre la deforestación en la Amazonía peruana: Causas y Perspectivas. AIDESEP and FPP, November 2014.

ANTÚNEZ DE MAYOLO R., Santiago (2011). La nutrición en el antiguo Perú. Sociedad Científica de Lima. Lima. 
BONFIL BATALLA, Guillermo (1982). El Etnodesarrollo: sus premisas jurídicas, políticas y de organización. In: América Latina: Etnodesarrollo, Etnocidio. Costa Rica. Ediciones FLACSO. BRACK EGG, Antonio (2007). Cambio climático y Amazonía estratégica. In Rumbos de sol E piedra. No. 51.

CABIESES, Hugo (2016). K’Intu - K’Intusqa: Sobre la hoja de coca y su defensa nacional e internacional. Heemskerk-Holanda. Lima, typewritten.

CABIESES, Hugo (2016). Consumo tradicional, industrialización benéfica y DRIS con coca. Talk for the "Drug Crop Production, Poverty, and Development" Forum. Open Society Foundations - OSF. New York.

CABIESES, Hugo (2003). Cifras sobre coca, cocaína y cocaleros. Lima, typewritten.

CABIESES, Hugo (1996). Commercialising coca: possibilities and proposals. Catholic Institute for International Relations CIIR. London. March.

CABIESES Molina, Fernando (2004). Cien siglos de pan: 10000 años de alimentación en el Perú. Universidad de San Martín de Porres-USMP. Lima.

CHIRIF, Alberto (2013). Auges y caídas de las organizaciones indígenas. In: Stefano Varese, Frédérique Apffel Marglin and Róger Rumrrill. Selva vida. De la destrucción de la Amazonia al paradigma de la regeneración. IWGIA, Copenhagen.

DE SOTO, Hernando (2010). La Amazonía no es Avatar. En: http:/ / www.ild.org.pe/es/nativos/la-amazonia-no-es-avatar

DURAND, Francisco (2007). El Perú fracturado. Fondo Editorial del Congreso, Lima.

GASCHÉ, Jorge and Vela, Napoleón (2012). Sociedad Bosquesina. Dos tomos. IIAP, CIAS, CIES. Iquitos.

GINOCCHIO Balcázar, Luis (2012). Pequeña agricultura y gastronomía: Oportunidades y desafíos. APEGA-OXFAM-SOS/ FAIM.GIZ.Lima.

GRIFFITHS, Tom (2005). Los Pueblos Indígenas y el Banco Mundial: experiencias de participación. Forest Peoples Programme. July.

GUDYNAS, Eduardo (2004). Ecología, economía y ética del desarrollo sostenible. Coscoroba Ediciones; CLAES-D3E. Montevideo.

HORKHEIMER, Hans (1973). Alimentación y obtención de alimentos en el Perú prehispánico. Comentarios del Perú 13. UNMSM, Lima.

HORKHEIMER, Hans (1958). La alimentación en el Perú prehispánico y su interdependencia con la agricultura. UNESCO, Programas de Estudio de la zona árida peruana. Lima.

KUYOTEKA, Ángel (1997). Mitología Uitota contada por un Aront "gente avispa". Editorial Loalon, Medellín.

LEÓN CANALES, Elmo (2013). 14000 años de alimentación en el Perú. UNSP. Fondo Editorial. Lima.

MUSSO, Eduardo (2012). "Perspectiva ambiental: vislumbrando al Perú real y concreto". Lima. In: http://blog. pucp.edu.pe/item/158462/perspectiva-ambiental-vislumbrando-al-peru-real-y-concreto

NEPSTAD, Daniel C. (2007). Los círculos viciosos de la Amazonía. Report produced for WWF.

OSPINA, William (2013). América Mestiza: El país del futuro. Penguin Random House, Grupo Editorial Colombia, Bogotá.

PAUTRAT, Lucila (2016). Políticas anticorrupción. Escuela de Gobierno y Políticas Públicas 
de la Pontificia Universidad Católica del Perú PUCP and Universidad del Pacífico. Marzo 2016. In: http:// www.lucilapautrat.net/Publicaciones/Anticorrupcion/CIES/Politicas-Anticorrupcion.pdf.

PNUMA-OTCA-UP (2009). GEO Amazonía: Perspectivas del Medio Ambiente en la Amazonía. United Nations Environment Programme, UNEP. Amazon Cooperation Treaty Organisation ACTO and Universidad del Pacífico - UP. Lima, 2009.

RUMRRILL, Róger (2017). La Amazonía: Sombras y luces. Anka Mayu Ediciones, Moyobamba, San Martín.

STAVENHAGEN, Rodolfo (Undated). El derecho de sobrevivencia: la lucha de los pueblos indígenas en América Latina contra el racismo y la discriminación. Proyecto IIDH/BID sobre actividades preparatorias de la Conferencia Mundial contra el Racismo, la Discriminación Racial y la Xenofobia. Mexico.

UNODC - United Nations Office on Drugs and Crime (2011). El costo económico de la delincuencia organizada en el Perú: Estudio sobre los costos directos que el crimen ocasiona al estado y las familias. https://www.unodc.org/docu ments/peruandecuador//Publicaciones / UNO-DC-costo-crimen.pdf.

UNODC - United Nations Office on Drugs and Crime (2010). The globalization of crime: A transnational organized crime. Threat assessment. United Nations publication printed in Austria Sales No. E.10.IV.6 - June.

UNODC-DEVIDA (2015). Perú: Monitoreo de Cultivos de Coca, Julio 2016. https: / /www. unodc.org/documents / crop-monitoring/Peru/Peru_monitoreo_coca_2016.pdf. 


\title{
THE GROWTH OF OIL PALM IN THE PERUVIAN AMAZON: DEFORESTATION AND LAND TRAFFICKING
}

\author{
Juan Luis Dammert B.
}

\section{Introduction}

Palm oil is not a major industry in Peru and the crop is far from being the main driver of deforestation in the Amazon (PNCBMCC, 2016). Around 80,000 hectares of oil palm has been planted in Peru, accounting for approximately $0.1 \%$ of the Peruvian Amazon and $1 \%$ of its deforested area. Oil palm cultivation has, however, expanded rapidly over the last decade and, more recently, plans have been revealed which, should they to come to fruition, would triple the area covered by this crop. Each of the large oil palm plantations in the Peruvian Amazon has involved the clearing of large areas of forest. Such deforestation tends to occur rapidly, and so aerial photos and satellite images can be spectacular, revealing industrial-scale environmental destruction as opposed to the gradual deforestation that results from most other activities in the region. The rapid growth in this activity, combined with evidence of rapid deforestation and the unlikely (but powerful) prospect of the Peruvian Amazon losing forests to oil palm plantations at a rate similar to Southeast Asia, has triggered environmental alarm bells regarding this crop in Peru.

Cases of deforestation for oil palm plantations in Peru have been widely documented (see, for example, SPDE, 2014; EIA, 2015; MAAP, 2017; Dammert et al., 2012; Dammert, 2015, 2017a and 2017b). Other works have discussed the socio-economic aspects of this crop (Fort and Borasino, 2016), the criteria for its optimal location in the Peruvian Amazon (Glave and Vergara, 2016), the legal and institutional framework supposedly governing the expansion of oil palm in the country (EIA, 2015; Dammert, 2016) and, more recently, the eco-political aspects of agroindustrial expansion more generally (Dammert, 2017b). This article provides an overview of oil palm cultivation in Peru and the deforestation caused by the extensive plantations established in the Amazon over the last decade. The extent to which this model has generated widespread deforestation and the legal mechanisms used for its development are therefore discussed along with the alternative models that have appeared in response to the emerging scandals. The increase in land trafficking as a new way of accessing land for the development of large-scale agricultural projects in the Peruvian Amazon is particularly analysed.

The general argument is contained in the following. There are large areas where - agronomically speaking - it would be possible to continue to expand oil 
palm in Peru; however, these are mostly covered by forest. Although there are significant material advantages to companies setting up in these areas, deforestation scandals have pushed them towards expansion methods alternative to the largescale projects developed on lands directly allocated by the State. The purchase of plots already titled to farmers has, for example, become an extensive practice, and the worst form of this results in land trafficking. This involves actively encouraging land to be titled to individuals or associations who then subsequently sell it on to agricultural businesses. Alongside this, the outsourcing of crop growing to small and medium-sized farms has also been promoted in an effort to try and develop the industry in already deforested areas. Given that the growth of large plantations in the Peruvian Amazon is a matter of constant dispute, however, it is not clear which direction the sector will move in over the coming years.

This article is divided into five sections. The introduction is followed by a section giving a general overview of the industry in Peru. The third section describes a number of controversial plantations that have resulted in vast areas of deforestation in recent years. The fourth discusses how the environmental controversy surrounding oil palm is creating new models of expansion and how these are linked to land trafficking. The last section offers some conclusions.

\section{Oil palm cultivation in Peru}

Oil palm is the most efficient oleaginous crop in the world, producing the greatest amount of vegetable oil per hectare sown. Between 1996 and 2013, the palm oil trade expanded by 500\%. Over this same period, palm oil's share of the vegetable oil market rose from $8 \%$ to 58\% (Corley and Tinker, 2016). Production is concentrated largely in Southeast Asia, where countries such as Indonesia and Malaysia account for more than $85 \%$ of the world's production. Despite this geographic concentration, the industry is constantly seeking new areas of expansion.

In Latin America, the area sown between 2006 and 2013 grew by 73\%. The greatest growth was noted in Mexico (275\%), Panama (187\%), Guatemala (185\%) and Peru (167\%) (Corley and Tinker, 2016: 21). There are vast areas of the Amazon suitable for oil palm cultivation - areas where, agronomically speaking, the plant can grow and produce relatively naturally. Butler and Laurance (2009) estimate that there are 230 million hectares of suitable land in the Brazilian Amazon. Pirker et al., (2016) calculate that there are likely to be 61.5 million hectares suitable for growing this crop in the Peruvian Amazon, i.e. virtually the whole region, with the exception of areas where the slopes are too steep. These estimates do not take into account the costs of fertilising the land and transporting oil from remote areas, and so they need to be taken with some caution. The most noteworthy point, however, is the enormous extent of potentially suitable land for cultivation in Peru.

Agricultural suitability is not the same as agricultural availability, however, i.e. the availability of lands over which there exist no other rights, or where the 
sowing of oil palm is not prohibited (such as protected natural areas) or where lands are not excluded by virtue of their forest cover. Due to these points, Pirker et al., (2016) estimate that the area actually available in the Brazilian Amazon is therefore reduced to 43.4 million ha and, in the Peruvian Amazon, 260,000 ha. In other words, vast areas of Peru that could be sown with oil palm are simply not available, mainly due to their forest cover and to the fact that deforestation is no longer acceptable either in public policies or on the markets, at least not openly.

According to the 2000-2010 National Oil Palm Plan, the total cumulative area sown with this crop in 2000 was 14,667 ha. The National Oil Palm Board of Peru (Junpalma) estimates that currently some 86,000 ha of oil palm have been sown.

Figure 1: Growth in area planted with oil palm in Peru, 2000-2014

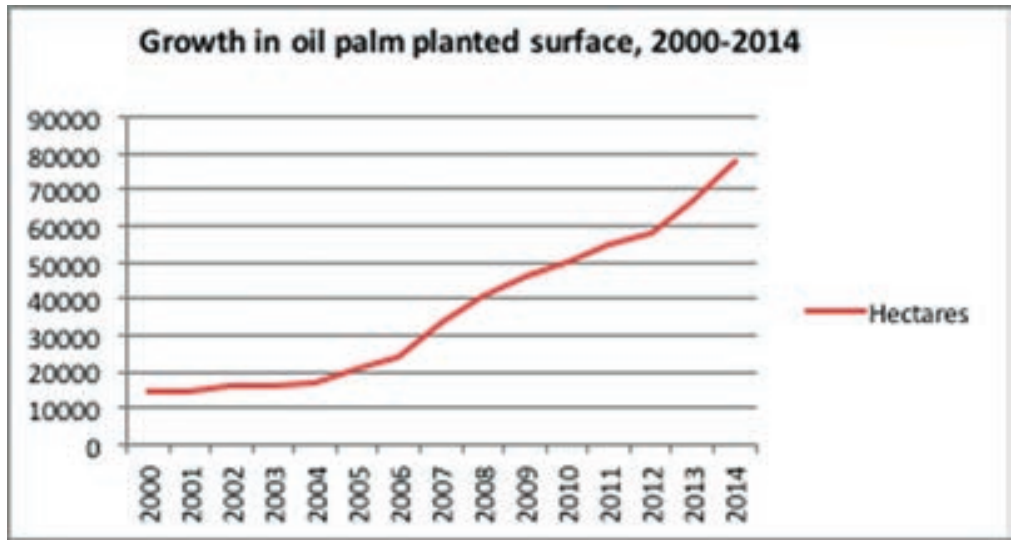

Adapted from JUNPALMA 2017

The Palmas Group (part of the Romero Group - the second most important business group in Peru) is one of the oil palm pioneers in the country and currently the biggest producer. This group has two large plantations: Palmawasi, in Tocache, and Palmas del Shanusi, near Yurimaguas, on the border between Loreto and San Martín. The Palmas Group is fully vertically integrated, selling crude palm oil, industrial products, biodiesel and consumer goods, to name but a few of its products. There are also the plantations of Ocho Sur, previously known as the Melka Group (the name given to the group of companies founded by the American/Czech citizen Dennis Melka, an investor with significant agroindustrial interests in Malaysia) which have two large plantations in Ucayali which cover around 11,000 ha in total. There is also a cocoa project that used to be linked to Melka, currently operating under the name of Tamshi Cacao, which has caused the deforestation of around 2,400 ha in Tamshiyacu, Loreto (see Dammert, 2017a).

The oil palm situation in Peru changed dramatically with the arrival of Melka's money. It represented the arrival of high-risk investments with strong 
links to financial markets, aimed at acquiring as much land as possible. Melka is a businessman who made his career in the financial sector and who has previously invested in agriculture, hotels and telecommunications. Melka has a background in the oil palm plantation business in Southeast Asia, where one of his previous companies, Asian Plantations Limited, made a fortune after investing in Borneo. The company was listed on London's Alternative Investment Market (AIM) in 2009 with a market capitalisation of GBP 22 million, which had increased to GBP 110 million by the time of its purchase by Felda Global Ventures, a Malaysian plantation behemoth. ${ }^{1}$ In Peru, the investor and his partners have developed plantations at a rapid pace. The group has a complex network of companies with inter-related sales and frequent changes of legal representatives that make it very difficult to monitor their activities. The head offices of these companies are based in tax havens such as the Cayman Islands (for a detailed analysis of the Melka Group see EIA, 2015; Salazar, 2014 and Salazar and Rivadeneyra, 2016).

In addition to these two corporate players, medium-sized companies and producer associations play a significant role in Junpalma, accounting for $50 \%$ of the total area sown in the country. These notably include palm oil extraction factories such as Olamsa, Indupalsa and Olpesa, and the producer associations that provide them with fresh fruit, namely Cocepu, Jarpal and Acepat respectively. From the early 1990s on, oil palm producers' associations and their associated extraction factories began to develop the promotion of palm oil as an alternative crop to coca. These projects, supported by the UN Office on Drugs and Crime (UNODC) and international cooperation, gave rise to what is currently known as the "United Nations model", which includes at least five extraction plants controlled by producer associations. Insofar as the most serious cases of deforestation have been linked to large plantations, the remainder of this article will focus on the largest and most controversial projects.

\section{Controversial plantations}

The four projects discussed in this section (Palmas del Shanusi, Plantaciones de Ucayali, Plantaciones de Pucallpa and Cacao del Perú Norte) are controversial for three reasons: they involved large-scale deforestation (as seen from satellite imaging); the legal processes used to access the land and establish plantations in previously forested areas were dubious; and they resulted in social conflicts of various intensities and with differing features.

In the case of Palmas del Shanusi (Palmas Group), established since 2006, it followed the process that was set out in Legislative Decree 653, the Law on Promoting Investment in the Agrarian Sector, and the subsequent requirements of the Forestry and Wildlife Law. A contract was signed in the context of L.D. 653 con-

1. See: http: / / www.bloomberg.com/research/stocks / private/ snapshot.asp?prcapid=82018551 
taining contractual obligations in order for the company to retain ownership of the land. This decree establishes a limit of 10,000 ha for agricultural holdings in the forest. To circumvent this limitation, however, business groups set up more than one company in order to develop contiguous projects over a larger area. The case in question consisted of three adjacent projects: Palmas del Shanusi, Palmas del Oriente and Palmas del Cainarachi. In the case of Palmas del Shanusi, the State awarded the company an area of 7,029 ha; they then bought a further 1,829 ha from landowners in the area. ${ }^{2}$ The neighbouring plot of Palmas del Oriente (the subject of a conflict with sectors of the population from Barranquita and the San Martín Regional Government) covered 3,000 ha, also allocated directly by the State. Finally, the original project included a third directly allocated plot: Palmas del Caynarachi, covering 6,128.4 ha. The company declined this plot, however, claiming that it had been invaded before they could develop it (Dammert et al., 2012).

This project, the second private large-scale plantation in Peru, commenced around 25 years after the first, Palmawasi, which is also owned by the Palmas Group. Of the four plantations considered here, it is the only one that was implemented in accordance with the State's requirements for the allocation of unrestricted lands, although the project was challenged and suffered a series of legal problems. The Palmas Group subsequently bought adjacent land from local farmers in order to extend the plantation; they have since halted this practice, in line with their new sustainability policy. ${ }^{3}$ Figure 2 shows the area deforested over time, estimated at around 15,000 ha.

2. The company subsequently continued to buy land from private individuals in monocropping areas although it is not clear how much land was involved.

3. This new policy can be found at: http: / / www.palmas.com.pe/palmas/el-gupo-palmas-hace-publica-su-politica-de-sostenibilidad 
THE GROWTH OF OIL PALM IN THE PERUVIAN AMAZON: DEFORESTATION AND LAND TRAFFICKING

Figure 2: Deforestation in the area of the Palmas del Shanusi project of the Palmas Group, 2000-2015

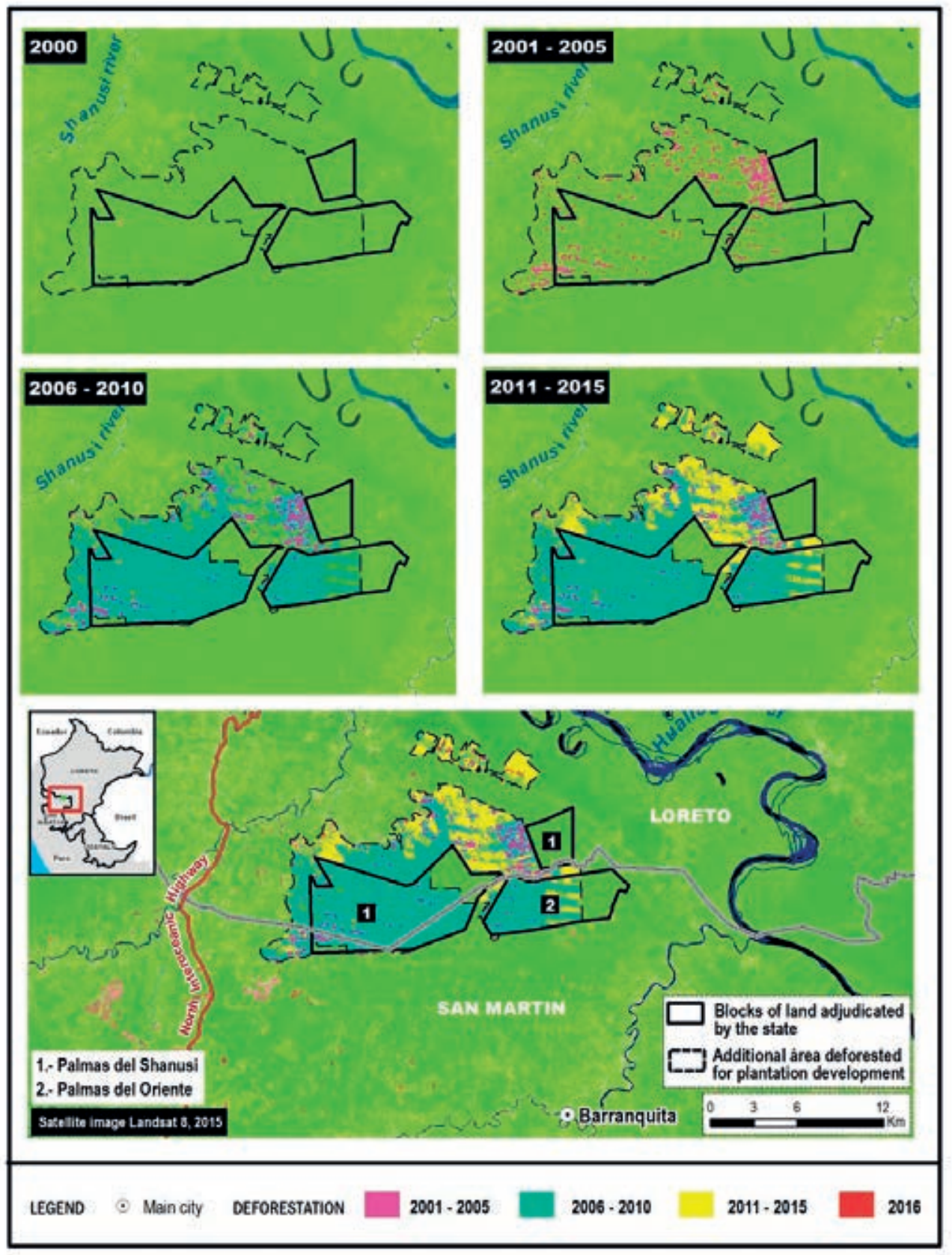


The three projects of the Melka Group - representing the pinnacle of socio-environmental conflict in Peru - have not followed the above procedure but instead show a number of innovative methods. In the case of Plantaciones de Pucallpa, the company bought land from the Palmeras de Tibecocha Association which, although it owned the land deeds, had little physical presence in the area apart from some commercial logging and a few plots of pasture. This association had accessed the land through what can be termed "ghost titles", titles issued not to formalise a spontaneous and de facto occupation of the land, as is often the case, but rather to title groups created expressly for the purpose of titling. This method is typical and involves people linked to the institution responsible for titling, identifying a particular zone and creating an association of close family, friends or others ready to "invest" in the process. They then complete the necessary formalities to register the land in the Public Registry. In the hard case of Tibecocha, the association was formed in 2006, it obtained a unique tax ID (RUC) and the Organisation for the Formalisation of Informal Properties (Cofopri) divided up the land in 2008, after which they began logging. The company subsequently sold all its lands to Plantaciones de Pucallpa in 2012.

Once these sales were complete, and once the company had begun logging, the community of Santa Clara de Uchunya realised that this was affecting land they were claiming as their ancestral territory. As a result the community embarked on a series of actions that has taken them as far as the Constitutional Court. Perhaps the most visible action, however, was a formal complaint submitted against Plantaciones de Pucallpa to the Roundtable on Sustainable Palm Oil (RSPO), focusing primarily on their claim to ancestral territoriality. With the support of the Federation of Native Communities of Ucayali (Feconau), Forest Peoples Programme (FPP) and the Legal Defence Institute (IDL), the community's authorities submitted a complaint indicating that the company was established on the community's ancestral territory and that the rapid expansion of oil palm in the area was directly affecting them. The complaint notes that the company bought the land without the community's free, prior and informed consent, and that the transaction had also resulted in large-scale deforestation, the commercialisation of timber species and the burning of vegetation to facilitate said deforestation. In addition, they referred to the massive deforestation that had taken place without any consultation with the local communities, destroying forests that the communities were using to hunt, fish and gather and which was a source of their medicinal plant and construction materials. The complaint was therefore explicit in highlighting that, in addition to forest and biodiversity protection as an end in itself, it was the livelihoods of the communities in areas where the plantation had been established that were at stake. ${ }^{4}$

4. The details of the complaint and the company's defence can be found here: http:/ / www. rspo.org/members / complaints/status-of-complaints / view/ 88 


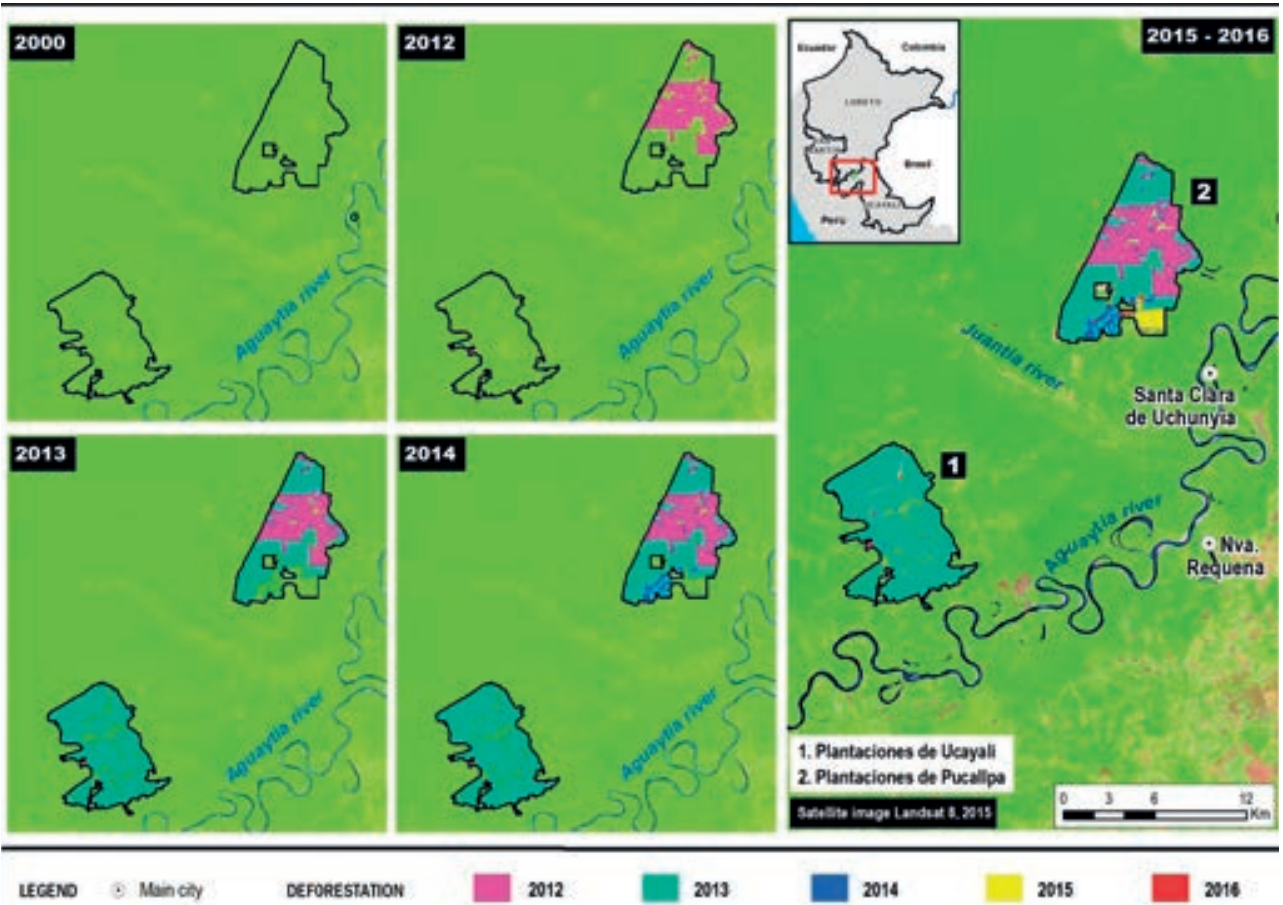

These kinds of social impact are all too common in large-scale projects but Plantaciones de Pucallpa has been the only one where the conflict has been packaged primarily in these terms. The fact that this plantation has affected a native community is key to understanding this dynamic: the organisational, legal and political resources which native communities have access to are greater than those of riverine mestizos settled in the Amazon region (even if they are numerically larger) because their rights are enshrined in international documents such as ILO 169.

On the other hand, in the case of Plantaciones de Ucayali, the Ucayali Regional Sector Directorate (DRSAU) incorporated a plot of 12,481 ha of "unrestricted lands suitable for agriculture" into the State domain following a request from the Ucayali Central Palm Growers Committee (Cocepu). A part of these lands was subsequently sold to Plantaciones de Ucayali. Cocepu submitted a complaint about this but it was dismissed. As part of the sale, the company submitted a Technical Economic Feasibility Study that was approved by the Regional Ucayali Government (GOREU) and there was also a legal report that indicated that the requirements had been met. All this took place at regional level (Dammert, 2015). In reality, the processes and requirements of the Forestry and Wildlife Law had not been followed, and this is one of the main reasons why environmental groups classify this as a case of illegal deforestation. 
In this case, the procedure took place in the context of Law 29151, the General Law on the System of National Assets. The DRSAU insists that it was simply "disposing of real estate" that it owned. Plantaciones de Ucayali's title deeds state that the price was set according to a "valuation conducted by which the lands subject to the direct sale were classified as having a greater use capacity", although we do not know by what procedure or instrument this land classification was undertaken, nor the details thereof (Dammert, 2015).

Finally, Tamshiyacu is a cocoa project being developed by Cacao del Perú Norte, a subsidiary of United Cacao (an undertaking headed by Denis Melka which, after conflicts between investors, changed its name to Tamshi S.A.C.). To date, the company has acquired some 3,985 ha and deforested around 2,380 ha to establish a plantation that is intended, according to United Cacao, to become "the largest cocoa plantation in the world". United Cacao stated that it hoped to sow 3,250 ha on plots it owned in 2017, with plans for a further 3,250 ha on the lands of small farmers affiliated to its Cocoa Strategic Production Association Programme (PAPEC), taking its total to 6,500 ha by 2021. In April 2016, Cacao del Perú Norte entered into negotiations with the Loreto Regional Government to access a further 2,135 hectares through a direct allocation of unrestricted lands, against payment, in an area adjacent to its existing plantation. It should also be recalled that, years previously, this business group had already submitted requests for more than 45,000 ha bordering its plantation for the development of oil palm projects; a request that has not materialised to date. The company has also continued to purchase land directly from farmers both in this and in other areas of the Amazon (Dammert, 2017a: 10). In other words, it was following a systematic strategy of purchasing land in Tamshiyacu. Since the disputes between investors and the change of name to Tamshi S.A.C., however, the new administration has stated that it does not intend to continue expanding the existing plantation. ${ }^{5}$

Much of the area acquired in Tamshiyacu to date came from the purchase of around 2,500 ha from private individuals who had acquired land from the State under Legislative Decree 838. In short, this decree enables those displaced by terrorism, beneficiaries of the Agrarian Reform and people who have been peacefully occupying public lands for more than a year to purchase them at no cost to themselves. These lands were titled as agricultural lands in the mid-1990s and the beneficiaries were largely teachers. This is therefore another case that can be described as "ghost titling". No communal cattle project was being undertaken in the area and only a few of the beneficiaries were working the land on a small scale. To develop their plantation, the company deforested the plots without conducting any environmental impact study and without any authorised change in land use. The company's argument was that the plots had already been titled for agricultural purposes and so there was no need to negotiate environmental permits (Dammert, 2015: 35-36).

5. Pers. comm. from executives of Tamshi S.A.C. in December 2018. 
Figure 4: Deforestation for cocoa growing in Tamshiyacu, Melka Group

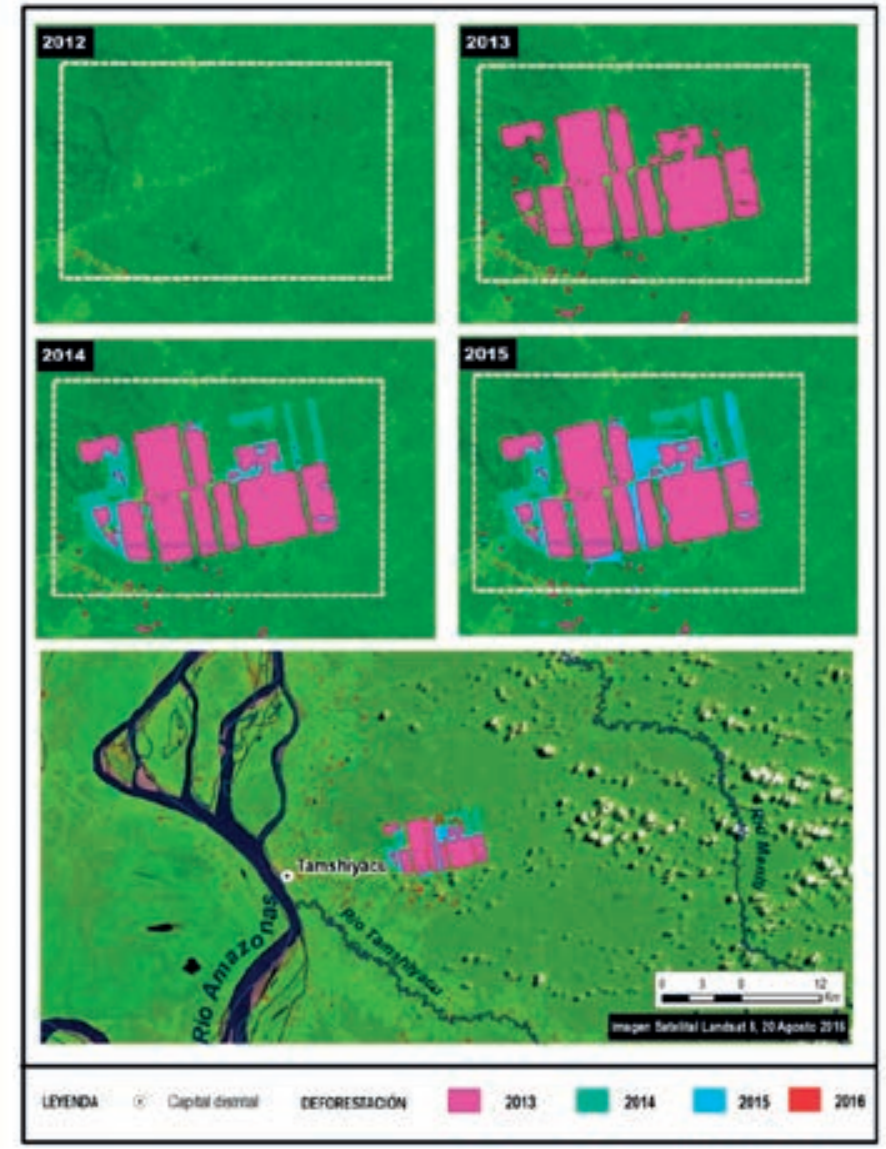

Taken from Dammert, 2017a

As noted, in addition to these four projects, there has been a series of initiatives negotiated over the last few years which have not come to fruition. They account for more than 100,000 ha. In the area of Tamshiyacu alone, where the cocoa plantation is being developed, five Melka companies entered into negotiations for a similar number of additional projects, representing a total of 45,160 ha: Plantaciones del Manití, Plantaciones del Perú Este, Plantaciones de Loreto Este, Plantaciones de San Francisco and Plantaciones del Perú Sur (Dammert, 2015). This shows that the cocoa plantation could well form the launch pad for the largest oil palm plantation in the country. The process initiated by the company for the allocation of more than 2,000 ha in Lot BB, adjacent to the existing cocoa plantation should also be noted, although the company withdrew this application in 2018.

The Palmas Group has also proposed at least four new projects in recent years: Santa Catalina, Tierra Blanca, Santa Cecilia and Manití. These applications 
initially made progress in terms of complying with the requirements but were challenged legally and are now at a standstill. The Palmas Group has now announced a new corporate strategy whereby it will no longer develop plantations if deforestation is required. These plans have therefore presumably been withdrawn.
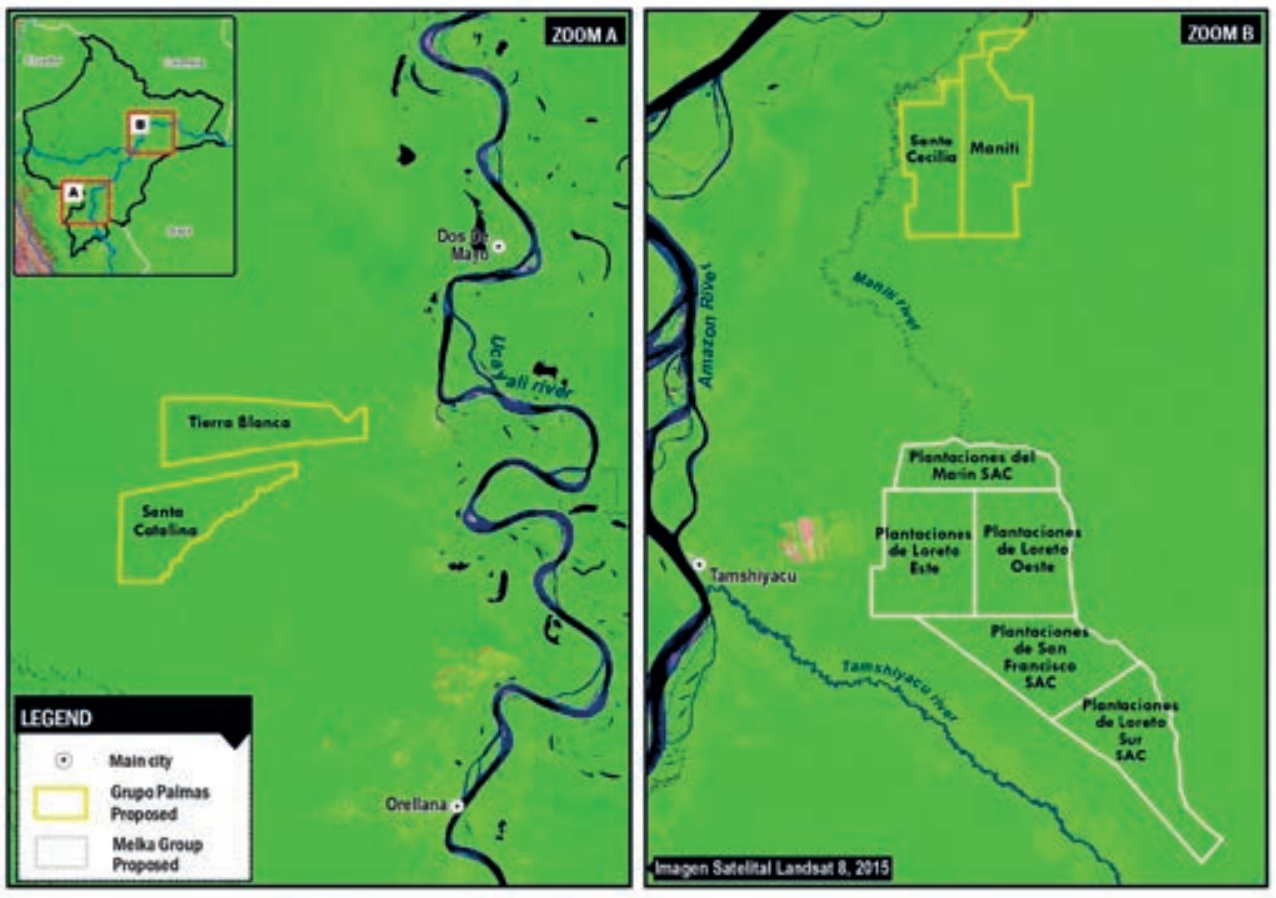

This list of projects is not exhaustive, however. Companies linked to the Melka Group had been planning to expand their activities over a far wider area than that developed to date, although it is difficult to estimate the total size. These companies have actively bought lands directly from rural owners in the Amazon region in recent years, particularly in Ucayali and Loreto. The Environmental Investigation Agency (EIA) recently found that the Group had bought around a further 10,000 hectares in addition to its current plantations. In 2016, United Cacao announced on the London Alternative Investment Market that it had entered into negotiations for a further 12,132 ha of new plantations.

\section{New methods of expansion and the phenomenon of land trafficking}

Replacing tropical forests with oil palm plantations results in serious and documented environmental impacts in terms of greenhouse gas emissions (Sheil et al., 2009; Carlson et al., 2013; Quispe et al., 2009), effects on local microclimates (Luskin and Potts, 2011), loss of biodiversity (Pin Koh et al., 2008; Fitzherbert et al., 2008; 
Sheil et al., 2009) and water bodies (Sheil et al., 2009); and in terms of fire dynamics (Laurance, 2003; Smit et al., 2013; Sheil et al., 2009) and the erosion and loss of soil fertility (Lord and Clay, 2011; Kimmins, 2004: Smit et al., 2013). This is why oil palm is rejected for environmental reasons.

As we have seen, the large plantations of the Peruvian Amazon have resulted in cases of deforestation. If the main criterion for deciding where to locate new plantations is the greatest possible profit, then buying cheap forested lands, clearing them, causing as little harm to the soil as possible and then developing a plantation is more economically attractive than purchasing deforested land, which tends to be more expensive and possibly more degraded. In the broader scheme of large plantations, deforestation is not only caused by the oil palm company but also by the settlement dynamics of the territory surrounding them. Large plantations attract settlers motivated by speculation, the prospect of accessing public services and of becoming economically involved with the companies. This scramble for land around mono-cropping ventures only exacerbates the deforestation of these areas.

The deforestation evidenced in the four projects developed over the last decade and the prospect of even greater expansion going forward, with investors experienced in establishing plantations in Southeast Asia, has created a national controversy that has included complaints to the Public Prosecutor, legal proceedings, cessation orders from Minagri (Ministry of Agriculture and Irrigation), fines imposed by regional governments, formal complaints in the Alternative Investment Market by a group of civil organisations led by the EIA and the formal complaint against Plantaciones de Pucallpa lodged with RSPO by the Native Community of Santa Clara de Uchunya and its partners that was previously mentioned.

Deforestation scandals are creating legal problems and closing off markets, and the companies need to consider these factors when considering their expansion strategies. Deforestation is no longer an acceptable practice by most standards, either public or private. For the practical purposes of the industry as a whole in the country, these conflicts have resulted in a stigmatisation of palm oil as a crop, despite, as already noted, approximately half the area sown being in the hands of small and medium-sized producers, many of whom represent successful cases of poverty reduction and of the substitution of illegal crops with formal production activities.

The oil palm companies are now developing different strategies to face up to these scandals and adapt to the new demands of the oil markets. In 2015, given the lack of domestic markets for nationally-produced palm oil and biodiesel, the oil palm companies created a unified federation (Junpalma) and called for an updating of the National Oil Palm Plan. ${ }^{6}$ In the discussions around approval of this

6. This update, coordinated by Minagri, which began at the end of 2015 and involved a participatory process, was set out in the pre-publication of a plan in July 2016. With the change of government in 2016, the future of the plan remained unclear. Around the middle of 2017, the Ministry of Culture confirmed that the National Plan needed to undergo a prior 
Plan, Junpalma proposed growing oil palm only in deforested areas. Junpalma is also promoting the certification of national production through RSPO as it believes the national industry will consequently be able to access new and larger markets. This certification requires the oil produced to come from plantations that have not caused deforestation or, where this is not possible, that mechanisms have been developed to offset this. Markets are increasingly demanding that palm oil should come from "sustainable" sources. With the prospect of expanding the sale of its production to international markets, the Palmas Group has become a member of the Forest Trust and of RSPO and, as previously mentioned, has published a new strategy whereby it publicly undertakes to ensure that its plantations do not result in deforestation. Along the same line, the Palmas Group is developing an expansion strategy based on developing production chains that include small producers rather than large plantations.

The situation of the Melka Group companies is different. Following the complaints to RSPO regarding the land conflict with the Santa Clara de Uchunya community and the evident deforestation, Plantaciones de Pucallpa announced that it was dropping its oil palm interests and would therefore be withdrawing from RSPO. Both this company and Plantaciones de Ucayali changed their names to Ochosur P and Ochosur U, respectively, claiming that they had been sold. Deforestation continued in the area around the plantations through farmers' associations, of which some were linked to the company and aimed at sowing oil palm. The Group has insisted that its plantations are legal and has put forward the narrative that it is encouraging the development of the Ucayali region, something that environmental NGOs are opposed to due to underlying interests. In the case of Tamshiyacu, however, United Cacao went into administration once Melka had been removed as an executive due to accusations of administrative mismanagement. The new administration then changed its name to Tamshi S.A.C. and announced new policies in the area, including one of no further deforestation.

As narratives and concrete alternatives to deforestation have appeared, however, so have new ways of accessing land that involve the deforestation of plots bought directly from individual owners. Peruvian legislation only permits those lands classified as agricultural to be titled. In terms of the titling of farmers, the land classification criteria have been relaxed so that the lands they are granted implicitly include the permission to deforest (legally this should not be the case but this is what has been happening in practice). It is interesting to note that the expansion of commercial farming has found this (the purchasing of individually titled plots) a simpler way of accessing land. The settler economy (settling on land to farm and then selling it on and seeking more land further afield, where the operation is repeated) and business ventures that also require lands on a larger scale

consultation process, in the context of ILO 169, to which Feconau subsequently submitted an application. The prior consultation process has not been implemented to date. 
are consequently brought together in the scramble for land. This logic results in invasions aimed subsequently at selling the land on to agricultural businesses.

This phenomenon demonstrates a new way of expanding agribusiness. The scandals surrounding the large plantations have meant that the mechanisms for accessing land anticipated to develop large agricultural projects in the Amazon (as set out in Legislative Decree 653 and the Forestry Law) are in practice no longer used for this kind of project. Instead, since around 2011, accessing land for largescale commercial agriculture has focused on the direct acquisition of land titles from small farmers. This has given rise to cases of land trafficking.

Land trafficking is the perverse and systematic use of the State's land titling mechanisms in order to put the land onto the market and make money from it (see Dammert 2018). In general terms, it consists of organising the occupation of land and then developing administrative procedures by which to get that land titled. Once this is achieved, however, they then sell the land on. Their calculation is that the future value of the land will be greater than its current value, and such cases are therefore more frequent in areas where infrastructure is planned or where there is another factor that suggests that the price of land will increase considerably.

Land trafficking is systematic by nature insofar as it creates structures dedicated to obtaining State lands and making money from them. These structures distort the titling mechanism, as they focus on using titling campaigns - aimed at regularising the occupation of peasant farmers' and native communities' territories and thereby providing them with legal security - to access land that can subsequently be sold to the highest bidder. Given their supervision of titling procedures in rural areas, agricultural departments are at the epicentre of the political manipulation of these pressures for land. Cases of this kind have been seen in Tamshiyacu (Dammert 2017a) and also in Ucayali where, at the end of 2018, the regional agricultural director was arrested on accusations of land trafficking because he had facilitated ghost titling for the subsequent sale of the land, as described in this text.

\section{Conclusions}

In conclusion, it can be seen that there has been a significant increase in oil palm cultivation in the Peruvian Amazon in recent years, albeit less than anticipated. Despite the agricultural suitability of large areas of the Amazon, the limiting factor for its greater expansion is that most of the lands are covered by forest. To date all oil palm projects developed in Peru have involved large-scale deforestation and this has resulted in a stigmatisation of the sector. There are, however, now economic and political incentives to encourage the industry to move towards an expansion that does not involve deforestation, although it is not clear if this will be in the general direction of oil palm cultivation over the coming years.

The usual model when faced with deforestation caused by oil palm is to move towards developing the activity in already deforested areas. This effectively 
means encouraging farmers settled in the Amazon to substitute their crops with oil palm and sell the fruits to processing factories, or for the existing companies to buy up deforested land. Deforested land tends to be degraded, however, and therefore unattractive to the industry. Futhermore, given its acidity, it is highly likely that it would qualify as forested or protected land under the current legal framework. In other words, the State should be flexible in its criteria for approving land surveys if the aim is to promote new projects on deforested land where the land is, however, classified as forested.

The idea of sowing oil palm in deforested areas also creates different challenges, such as obtaining cleared land at a price that is not prohibitive for the industry, or of avoiding a widespread land trafficking dynamic in which third parties deforest with the express aim of selling on to companies. These dynamics are difficult to control when the State has very little operational capacity in the rural areas of the Amazon and when one considers that, in addition, the State has historically been a participant, facilitator and legitimiser of the activities that have resulted in the country's deforestation. The future of oil palm in deforested areas is therefore a complex challenge.

The large plantation model developed on forested lands allocated by the State is a declining model. Since the allocation made to Palmas del Shanusi in 2006, all projects have used methods of accessing land other than the procedure stipulated in L.D. 653 and the requirements set out in the Forestry Law. It is unlikely that the Peruvian State will promote large plantations in areas under forest cover in the future. The mechanism that has been extensively used, primarily by companies of the Melka Group, has been that of direct acquisition from titled farmers, arguing that, as they are already titled plots, they are de facto classified as agricultural. In its worst form, this model results in land trafficking that promotes invasions, titling with the complicity of the regional authority and subsequent incorporation of the land into commercial oil palm circuits, either through direct ownership by the companies or third parties.

This proliferation of land trafficking goes hand in hand with the transfer of agricultural, forestry and land titling powers to regional governments, which do not always have the resources and capacities necessary to meet their obligations. There are also gaps in national legislation on accessing forested lands. As argued above, it is far easier for agribusinesses to access lands by purchasing them directly from farmers than by following the State's allocation procedures, which impose stricter conditions. Some parts of the industry have thus viewed land trafficking as a new way of accessing lands and expanding plantations, and the extensive use of this method is eroding the sustainability efforts being made by other sectors of the industry. 


\section{BIBLIOGRAPHY}

BUTLER, R.A. and Laurance, W.F. (2009). "Is oil palm the next emerging threat to the Amazon?". Tropical Conservation Science Vol.2 (1):1-10.

CARLSON, K., Curran, L.M., Asner,G.P., McDonald Pittman, A., Trigg, S.N. and Adeney, J.M. (2013). "Carbon emissions from forest conversion by Kalimantan oil palm plantations". Nature Climate Change Vol. 3, March.

CORLEY, R.H.V. and Tinker, P.B. (2016). The Oil Palm. Fifth Edition. World Agriculture Series. Oxford. Wiley Blackwell.

DAMMERT, J.L., Cárdenas, C. and Canziani, E. (2012). Potenciales impactos del establecimiento de cultivos de palma aceitera en el departamento de Loreto. Cuaderno de Investigación 8. Lima, SPDA. Available at: http:/ / www.actualidadambiental.pe/wp-content/uploads / 2012 / 06 / Cuaderno-8-SPDA-Cultivos-de-Palma-Aceitera-en-Loreto.pdf

DAMMERT B, J.L. (2015). Hacia una ecología política de la palma aceitera en el Perú. Lima, Oxfam.

DAMMERT, J.L. (2016). "Promoción y regulación ambiental de la palma aceitera en el Perú: Aspectos legales e institucionales". In:Fort, R. and Borasino, E. (eds.). ¿Agroindustria en la Amazonía? Posibilidades para el desarrollo inclusivo y sostenible de la palma aceitera en el Perú. Lima, Grade. Available at: http://www.grade.org.pe/wp-content/uploads/LIBROGRADE_palma.pdf

DAMMERT, J.L. (2017a). Acaparamiento de tierras en la Amazonía peruana: el caso de Tamshiyacu. Lima, WCS.

DAMMERT Bello, J.L. (2017b). Contested Booms. The Politics of Oil Palm Expansion in the Peruvian Amazon. Doctoral thesis from the Graduate School of Geography, Clark University, Massachusetts. Available at: https: / / pqdtopen.proquest.com/doc/1929526996.html?FMT=ABS

DAMMERT, J.L. (2018). Land Trafficking: Agribusiness, Titling Campaigns and Deforestation in the Peruvian Amazon. Talk given to the Annual World Bank Conference on Land and Poverty. Washington, D.C. March 2018. Available at: https://www.conftool.com/landandpoverty2018 / index.php / 06-09-Dammert-377_paper.pdf?page=downloadPaper\&filename=06-09-Dammert-377_paper.pdf\&form_id=377\&form_version=final

EIA (Environmental Investigation Agency). (2015). Deforestation by Definition. The Peruvian government fails to define forests as forests, while palm oil expansion and the Malaysian influence threaten the Amazon. Environmental Investigation Agency. Available at: http:// eia-global.org/news-media/ eia-report-exposes-illegal-deforestation-of-peruvian-amazon-for-palm-oil-cu

FITZHERBERT, E., Matthew, B., Struebig, J., Morel, A., Danielsen, F., Carsten, A., Brühl, P., Donald, F. and Phalan, B. (2008) "How will oil palm expansion affect biodiversity?" Trends in Ecology and Evolution Vol.23 No.10.

GILBERT, N. (2012). "Palm-oil boom raises conservation concerns. Industry urged towards sustainable farming practices as rising demand drives deforestation". Nature Vol. 4875 July.

GLAVE, M. and Vergara, K. (2016). “Modelos de localización de áreas potenciales para el cultivo de palma aceitera sostenible en el ámbito amazónico del Perú". In Fort, R. and Borasino, E. (eds.).¿Agroindustria en la Amazonía? Posibilidades para el desarrollo inclusivo y sostenible de la palma aceitera en el Perú. Lima, Grade. 
JUNPALMA (Peruvian National Oil Palm Board). (2017). Agroindustria de la Palma Aceitera: Alternativa Sostenible que Promueve Desarrollo socioeconómico en la Amazonia. Lima.

JUNPALMA. Available at: http://junpalmaperu.org/files/Agroindustria-de-la-palmaaceitera-en-Peru.ENERO2017.pdf

JUNPALMA. (2016). Estadística de la Palma Aceitera al 2014. Lima, JUNPALMA.

KIMMINS, J.P. (2004). Forest Ecology: A Foundation for Sustainable Management, 3rd Edition. Prentice Hall.

KOH, L.P. and Wilcove, D.S. (2008a). Is oil palm agriculture really destroying tropical biodiversity? Conservation Letters 1: 60-64

$\mathrm{KOH}$, L.P. and Ghazoul, J. "Biofuels, biodiversity, and people: Understanding the conflicts and finding opportunities". In: Biological Conservation 141 (2008) 2450-2460. p. 2455.

KONGSAGER, R. and Reenberg, A. (2012). Contemporary land-use transitions: The global oil palm expansion. GLP Report No. 4. GLP-IPO, Copenhagen.

LAURANCE, W.F. (2003). Slow burn: the insidious effects of surface fires on tropical forests. Trends in Ecology and Evolution 18(5): 209-212.

MAAP (Monitoring of the Andean Amazon Project). (2017). Portal http:/ / maaproject.org/ en/

MINAG. (2001). Plan Nacional de Promoción de la Palma Aceitera 2000-2010. Lima, MINAG.

PIRKER, J., Mosnier, A., Kraxner, F., Havlík, P. and Obersteiner, M.. (2016). What are the limits to oil palm expansion? Global Environmental Change 40 (2016) 73-81

PNCBMCC -National Forest Conservation Programme for Climate Change Mitigation. (2016). National Forests and Climate Change Strategy. Lima, MINAM. Available at: http:/ / www.bosques.gob.pe/archivo/enbcc-ds-007-2016-minam.pdf

QUISPE, I. et al., (2009). Impactos ambientales de la producción de biocombustibles en la Amazonía peruana. Análisis de ciclo de vida de la palma aceitera y Jathropa curcas. SNV, WWF, PUCP.

SALAZAR, M. (2014). Reporte Nacional Tras la Marca: Estudio Exploratorio sobre Inversiones de Origen Malayo en el Sector de Palma Aceitera. Unpublished document prepared for Oxfam.

SALAZAR, M., Rivadeneyra, D. (2016). Amazonía arrasada. El grupo Melka y la deforestación por palma aceitera y cacao en el Perú. Convoca/OXFAM/Kené. Lima, Peru.

SHEIL, D., Casson, A., Meijaard, E., van Nordwijk, M., Gaskell, J., Sunderland-Groves, J., Wertz, K. and Kanninen, M. (2009). The impacts and opportunities of oil palm in Southeast Asia. What do we know and what do we need to know? Occasional paper No. 51. CIFOR (Center for International Forestry Research), Bogor, Indonesia.

SMIT, H.H, Meijaard, E., van der Laan, C., Mantel, S., Budiman, A., et al., "Breaking the Link between Environmental Degradation and Oil Palm Expansion: A Method for Enabling Sustainable Oil Palm Expansion". PLoS ONE 8(9): e68610. doi:10.1371/journal.pone.0068610, 2013

SOCIEDAD PERUANA DE ECODESARROLLO (SPDE). (2014). Observatorio de biocombustibles en el Perú: www.biofuelsobservatory.org 



\section{FIGHTING ILLEGAL LOGGING IN PERU: \\ THE GOVERNMENT'S STEPS FORWARD AND THE INDUSTRY PUSHBACK}

\section{Julia M. Urrunaga B.}

"The dirty money coming to our economy is not coming only from corruption and drug dealing anymore. Now it also comes from illegal mining and illegal logging. These illegal activities have started to take over our territory and to penetrate politics due to the lack of a State capable of bringing order, basic services and development opportunities to our regions." 1

Peru's former President of the Cabinet of Ministers, Cesar Villanueva, on his first speech to the Peruvian Congress on May $2^{\text {nd }} 2018$

For the last couple of decades, it has been public knowledge that the timber being harvested, traded and exported from Peru has a high risk of being illegal. Building upon the extensive investigative and policy work conducted by civil society, academia, the indigenous organizations and a few governmental agencies, Peru's customs authority (Sunat) ${ }^{2}$ initiated a special operation in $2014^{3}$ aimed at coordinating the work of different institutions to identify and stop the national and international trade in illegally logged timber. The amount and impact of the data revealed through Operation Amazonas would bring Peru to the critical crossroads it is at now.

A couple of years previously, The Laundering Machine, a multiannual investigative report published by the Environmental Investigation Agency - EIA (the international non-profit organization whose work in Peru I have been leading for the last decade), proposed a methodology to verify the legal - or illegal - origin of the timber, bringing together different pieces of originally isolated information collected and produced by different agencies of the Peruvian government and - based on this data - providing documented evidence of the illegal origin of hundreds of shipments of timber exported from Peru to the United States between 2008 and

1. Villanueva, Cesar. May 2, 2018. Speech at Peruvian Congress. http:/ / www.pcm.gob.pe/ wp-content/uploads/2018/05/discurso-de-investidura-del-presidente-del-consejo-de-ministros-cesar-villanueva-ante-el-congreso-de-la-republica.pdf

2. Superintendencia Nacional de Aduanas y de Administracion Tributaria, SUNAT. http:/ / www.sunat.gob.pe

3. WCO. "Trade in illegal timber target of WCO and INTERPOL supported operation in Peru". July 25, 2014.

http: / / www.wcoomd.org/en/media/ newsroom/2014/ july/ trade-in-illegal-timber-target-of-wco-and-interpol.aspx 
2010. ${ }^{4}$ The picture was not pretty but, even worse was that - due to data limitations - this report focused mainly on the trade in timber species protected under the international convention for endangered species, CITES, which should imply additional provisions to guarantee a legal origin. ${ }^{5}$ If The Laundering Machine could document hundreds of CITES permits that "validated" the international trade in protected yet illegally logged timber species, how bad might the situation be for the harvest and trade in non-internationally protected timber species? A few years later, Sunat's Operation Amazonas was to use the same methodology proposed by The Laundering Machine to document dramatic levels of trade in and exports of laundered illegally logged timber of many more species.

In 2015, based on Sunat's special operation and data, the United States stopped and destroyed two different shipments of illegal Peruvian timber that had arrived at its borders and, since 2016, it has started paying special attention to timber shipments coming from Peru as a way of implementing the U.S. Lacey Act: a law that makes it illegal to import to the U.S. timber that has been harvested or traded in violation of the laws of the country of origin. ${ }^{6}$ The success of this operation has generated a strong lobby from the industry to modify national regulations and procedures in order to try and make it impossible to connect any future shipment with the point of harvest of the timber - instead of trying to make sure that no timber with an illegal point of harvest is traded.

More recently, in the last couple of years, the office of the United States Trade Representative, in charge of U.S. foreign trade, banned two Peruvian timber exporters after the Peruvian government provided official evidence that they were exporting illegally logged timber to the United States. Inversiones La Oroza SRL

4. Urrunaga et al., The Laundering Machine. EIA, 2012. https:/ / eia-global.org/reports/ the-laundering-machine

5. 2015, MINAM. Cites en Peru. Conservando nuestras especies silvestres. http:/ /www. minam.gob.pe/diversidadbiologica / wp-content/ uploads / sites / 21 / 2014 / 02 / folleto -cites-19.06.15.pdf

6. For detailed official information about the Lacey Act, see the United States Department of Agriculture: http:/ / www.aphis.usda.gov/aphis/ourfocus/planthealth/import-information/sa_lacey_ act/ct_lacey_act/!ut/p/z1/tZJLc4IwFIV_i4sumSSKBJZAGbBV21ERyIaJESQtLyHa21_fyHSmr1HrotkkJ7lncs98FxAQAILSPd9QwauS51JHRIunyHahrqKx69wiaHrG6N7DGrQNDIKuYPyg2siaQ7k7FjSdGZ44zqgP0QCQ6_xLT5P-hb-Y6sgaGf2_-eGJZcJL_iUggNSMr0EEMdRhqmKFaamuqNQYKitN0xREcTLESKVwvTpWs1LUIgMRrTPexqwqRVKKOOerhjaHG9jSuNo1cVqxXdupOqfyPUtoLrLughd11YjumFOWHGLKpGLiU33EOtM3OZ86ODZ6Goyr988XdOR-FPxGc6mLSKbAJ1M8DkGw58kL8MuqKeSwza9k4UFwd4mvHGD-tN0SU3I7knoVIPxPcPK_fjOxJxuZhIpM4WVagfCrAYTfDHXh-36hDw7K88x7s6aKG-it2eu9A_xLGKQ! / dz / d5 / L2dBISEvZ0FBIS9nQSEh / ?urile=wcm\%3Apath\%3A\%2Faphis_content_library $\% 2 F s a$ our_focus $\% 2$ Fsa_plant_health $\% 2$ Fsa_import $\% 2$ Fsa_lacey_act $\% 2$ Fct_lacey_act

7. Urrunaga, Julia et al., Moment of Truth. EIA, January 2018. https:// content.eia-global. org/posts / documents / 000/000/694/ original/MomentofTruth.pdf?1520443534 
was banned in $2017^{8}$ and Inversiones WCA EIRL in 2019. ${ }^{9}$ Both companies had previously been identified by EIA - both in The Laundering Machine (2012) and Moment of Truth (2018) - as trading illegally logged timber to different destinations worldwide, including the U.S. In addition, EIA reports have documented that several other Peruvian exporters are operating just like the companies that have already been banned and are continuing to conduct their business as usual. ${ }^{10}$

And this is how Peru has arrived at a critical crossroads: on the one hand, it has proved that it has the capacity to identify and stop the trade in illegally logged timber from its valuable natural forests. On the other, the industry has proved its powerful influence to get the government to modify and reduce standards in order to make it harder to document the real origin of the timber, be it legal or illegal. ${ }^{11}$ The question is: what path will Peru take? The long term one, aimed at preserving its natural forests and resources for the sake of future generations, the environment and the planet? Or the short-sighted one, aimed at keeping the industry and exporters happy today, at the cost of the destruction of the forests and biodiversity, the violation of local and indigenous communities' human rights, a proliferation of corruption and a potential ban on Peruvian timber on the international - and also more profitable - markets?

\section{The size of Peru's illegal timber sector}

There are no official figures on the extent of illegal logging in Peru but an analysis of the (limited amount of) available data reveals that illegality in the sector is greater than the legal trade. ${ }^{12}$ While, for at least the last couple of decades, it has been widely known that a large percentage of the timber harvested, traded and exported from Peru is at high risk of being of illegal origin (different public and private institutions have used numbers ranging from between $60 \%$ to over $90 \%$ ), the official position for a large sector of the government and industry has been that there is no hard evidence to prove it. ${ }^{13}$

8. USTR statement, October 19, 2017: https://ustr.gov/about-us/policy-offices/press-office/ press-releases / 2017 / october/ ustr-announces-unprecedented-action

EIA press release: https://eia-global.org/press-releases/strong-USTR-action-adds-to-Increasingly-serious-consequences-for-International-timber-smugglers

9. USTR announcement, July 26, 2019: https://ustr.gov/about-us/policy-offices/press-office / press-releases / 2019/july/ustr-announces-enforcement-action

EIA press release: https: / / eia-global.org/press-releases / 20190726-us-blocks-peruvian-illegal-timber-exporter

10. For a list of Peruvian exporters and international importers involved in the trade in illegally logged timber, see "Moment of Truth", chapters 4 and 7. https: / content.eia-global. org/posts / documents / 000 / 000 / 694/ original/ MomentofTruth.pdf?1520443534

11. MOT

12. Cite Moment of truth and resolution against Inversiones La Oroza

13. MOT 
After The Laundering Machine (2012) proved with official documents that over one-third ${ }^{14}$ of the Peruvian CITES timber species exported to the U.S. between 2008 and 2010 were of illegal origin, EIA's next investigative report, Moment of Truth (2018), presented more recent and more dramatic evidence for many more timber species. While it has been extremely challenging to access relevant and reliable data, for cases where we have been able to do so, we have identified several timber export shipments in which over $90 \%$ of the produce was of documented illegal origin. ${ }^{15}$

According to the World Bank, $80 \%$ of Peru's timber exports are of illegal origin ${ }^{16}$ but officers from the Peruvian forest sector claim that there is no evidence to support that figure. However, a well-documented 2018 study from the Peruvian government institution in charge of investigating asset laundering in the country, the Financial Intelligence Unit (Unidad de Inteligencia Financiera - UIF), found that, in more recent years, over $60 \%$ of the Peruvian timber sector's assets have been of illegal origin (60\% for 2016, 65\% for 2015). ${ }^{17}$ When some forest sector officers tried to complain, arguing that this number was overestimated, the authors of the UIF study - based, among other things, on surveys and interviews with industry, government and civil society, as well as disaggregated GDP data analysis - explained that the real figure was actually likely to be higher since they had not included many highly questionable cases where the data or the evidence was not complete. The UIF report also concludes that Peru's production of illegal timber in the last 5 years has been over 1,100,000 cubic meters per year - which implies the illegal harvesting of around 150,000 natural forest trees per year, degrading some 300,000 hectares of natural forests every year. ${ }^{18}$ "The illegal timber is introduced to the market in an entirely illegal way or gets formalized through false information. In both cases, the corruption that is widespread in the main timber harvesting areas is the main factor facilitating and promoting the illegal timber trade". ${ }^{19}$

Osinfor, the Peruvian government office in charge of overseeing timber harvesting activities in the country, has been documenting (through verification

14. Between the lack of transparency of some offices and the lack of budget from others to produce more abundant data, EIA gained access to verify the legal (or illegal) origin of just some of the shipments. From what we could see in the documents and in the field and from multiple testimonies gathered, we have reason to assume that, if there had been more data, the percentages of illegality would have risen dramatically.

15. MOT

16. World Bank, Justice for Forests (complete citation). 2012

17. uif study (complete citation) http://www.sbs.gob.pe/portals/5/jer/estudio-analisis -riesgo/ers\%20madera\%20-\%20informe\%20final.pdf

18. Osinfor, 2019. https:/ / www.osinfor.gob.pe/wp-content/uploads/2019/06/RESOLUCION -DE-JEFATURA-00049-2019-OSINFOR-01.1.pdf Resolución de Jefatura 049-2019-OSINFOR. "Criterios para estimar la gravedad del daño por la comisión de infracciones en material forestal." Lima, 11 de junio del 2019.

19. UIF p. 80 
in the field) and reporting high levels of illegal harvesting and timber laundering for years, with little reaction from the country's other authorities - until Operation Amazonas used it to document illegalities, whereupon other countries started taking action. For the period 2014 - 2017, Osinfor documented yearly percentages of illegally logged timber varying from between $67 \%$ to $88 \%$ of the total timber being produced in the country. ${ }^{20}$

At the moment of writing this paper, U.S. cooperation is working with the Peruvian government to design a methodology by which to estimate the size of the Peruvian illegal timber sector. While one might or might not agree with the methodology or with the figures it will come up with, it is important for the country to have an official and transparent way of estimating the size of its illegal timber production and trade so that, first, the methodology can be reviewed and discussed (and potentially criticized and improved) and, second, there is a number that can be analyzed over time, revealing trends and, hopefully, progress.

\section{How the illegal timber gets laundered}

Simplifying the process for the sake of the non-specialist reader, the Peruvian regulations offer two main paths to gain legal access to natural forests for timber harvesting: permits (for indigenous communities and farmers with rights over forested lands who want to harvest timber for commercial purposes) and concessions (for those who do not have rights over forested land and request access to government owned land).

"Timber in Peru can be extracted legally from several different types of natural forest sources. Historically predominant among these are Permanent Production Forests - land in the public domain that has been granted by the Ministry of Agriculture in the form of concessions - and indigenous community forests. But logging may also be authorized on private properties and increasingly in local forests, areas granted by the regional governments to organized community groups officially recognized by their municipalities. Under Peruvian law, all of these legal arrangements for timber harvest rights are called "titulos habilitantes"; in this report, the term "logging contracts" is used for ease of understanding. (Other sources subject to different permitting processes include land authorized to be deforested for infrastructure, roads, mines, etc. and planted trees on private properties, either in plantations or agroforestry systems such as wind barriers.)" 21

A timber concession is granted to a private actor, after a public bidding process, for a period of 40 years. Each year the concessionaire can only harvest on

20. El Comercio. https:/ / elcomercio.pe/peru/60-madera-movilizada-peru-2017-tuvo-origen-ilegal-noticia-558040

21. MOT, p. 8 
a specific plot of the concession, which has to be pre-approved by the national or regional authority (depending on the level of decentralization of the national governmental structure for the specific jurisdiction). Similar rules apply to the other forms of timber contract in the country.

To obtain the legal authorization to harvest timber from a specific plot of forest, whoever holds a right over the land - concessionaires, communities, local forest managers or private property owners - must produce and submit an Operational Plan (PO, according to its acronym in Spanish) that includes a detailed forest inventory identifying and georeferencing each and every one of the trees to be cut and those to be left standing as seedling trees. (Until recently, the PO only covered a year of operations; with the most recent Forest Law, it can now cover up to three years. ${ }^{22}$ ) This PO must be produced and signed by a private forest engineer - who must hold an active registration with the professional association for engineers ( $\mathrm{Co}$ legio de Ingenieros) and be pre-approved by the national forest authority - and then it must be verified and approved following a field visit from a regional government officer to validate the veracity of the PO's forest inventory.

Once the PO is approved, the concessionaire receives the equivalent of a checking account with a positive balance that details the number of trees and cubic meters that he will be able to harvest and trade for each of the commercial timber species documented on the PO's forest inventory as verified and approved by the regional forest authority.

On paper, the Peruvian system seems detailed and focused and with different levels of checks and balances that would make illegal logging hard and inefficient. But what happens in reality - as was documented in plenty of case studies in The Laundering Machine ${ }^{23}$ - is that a large number of the forest inventories are entirely or mostly fabricated.

Once the concessionaires or permit holders have authorization to harvest and trade a number of non-existent trees that are supposedly on their land, they basically use the papers to launder illegally harvested timber and make it appear - on paper - as if the timber had come from a legal point of harvest. In order to detect this illegal validation of non-existent trees - which thus far has required the collusion of at least three different actors - the timber company, the forest engineer and the regional government authority - one must compare the timber paperwork for any specific shipment with the situation at the point of harvest declared in the papers.

How do you verify the situation at the point of harvest? The Peruvian government's Agency for Supervision of Forest and Wildlife (Osinfor) ${ }^{24}$ has, among other responsibilities, the task of going into the field to verify the legality of the

22. Peruvian Forest Law 29763.

23. Urrunaga, 2012. The Laundering Machine.

24. Osinfor. Organismo de Supervision de los Recursos Forestales y de Fauna Silvestre. https:/ / www.osinfor.gob.pe 
harvest activities undertaken by the concessionaires. Osinfor's field supervisors are supposed to locate and measure the stumps of the trees that were georeferenced for harvesting in order to verify that the volume reported as harvested and traded by the concessionaire matches the evidence found in the field. In many cases, however, they cannot find the stumps or the trees. In some cases, the trees are still standing although the paperwork reports that they have already been traded. In others, the area where the trees were mapped as being is just a very large swamp with no trees at all. Over the years, Osinfor has documented many hundreds of fabricated forest inventories corresponding to timber harvest contracts that have - on paper - harvested and traded tens of thousands of non-existent trees.

The methodology developed for The Laundering Machine consisted of comparing the $\mathrm{PO}$ or point of harvest declared by the exporter with the Osinfor field report for that same $\mathrm{PO}$ or point of harvest. While it sounds easy and straightforward, the first challenge was to obtain the data to be compared. Peru has a good transparency and access to information law ${ }^{25}$ but some public offices do not have the budget or staff to deal with the requests and others still do not like the idea of sharing their data. It took EIA over 9 months of struggling with the forest authority to gain access to thousands of pages of blurred photocopies which, according to Peruvian law, should have been delivered in a week. The second challenge was to read those blurred photocopies and manually type all the relevant information into an Excel sheet.

In addition, one of the big challenges of the data analysis for The Laundering Machine was that the forest authority claimed that they only had records connecting export containers with points of harvest for the timber species protected under the CITES ${ }^{26}$ Convention, which for Peru are mahogany and Spanish cedar. Another major challenge here was that many of the POs declared as points of harvest for the timber in the alluded shipments had not been verified by Osinfor. This was in part because Osinfor has a limited budget, and many of the places are very hard to reach, but also in part due to the regional government not informing Osinfor on time (within a maximum 15 days, according to Peruvian legislation ${ }^{27}$ ) about the new POs being approved. If a PO is not reported to Osinfor, the PO does not exist for Osinfor, Osinfor will not verify it and, therefore, it will never come up as part of Osinfor's Red List.

For Operation Amazonas 2014, 76.5\% of the points of harvest declared by the exporters did not exist in Osinfor's system, which means that the regional authority that approved them never informed Osinfor about them. For the first three

25. Peru, Ley 27806, Ley de Transparencia y Acceso a la Informacion Publica. August 2, 2002. https: / / www.peru.gob.pe/normas/docs / LEY_27806.pdf

26. Cites. Convention on International Trade in Endangered Species of Wild Fauna and Flora. https: / / www.cites.org

27. Second complementary disposition of the Regulations to Legislative Decree 1085. 
months of Operation Amazonas 2015, this percentage was up to $100 \% .{ }^{28}$ By using papers from contracts that had not been reported to Osinfor, the exporters could rest assured that no red flags would come up were anyone to check Osinfor's database SIGO. ${ }^{29}$

In contrast to The Laundering Machine, Operation Amazonas could access the point of harvest information for all the species being exported from the Peruvian port of Iquitos. Sunat, being the taxes and customs authority, can conduct special operations and request additional documents, so they asked the exporters to share the transport guide (GTF), the document that must accompany the timber when it is being transported from one place to another. While Peruvian legislation still does not require the exporter to include this GTF as part of the export documentation although the Peruvian government committed to do so in November $2016^{30}$-Sunat can still request the companies share them.

Operation Amazonas, led by Sunat with the support of Osinfor and the Environmental Prosecutors Office, FEMA, followed a basic three-step approach: first, collect the data at the point of export (the Amazon river port of Iquitos); second, send the data to Osinfor, asking them to crosscheck with the results of their field verifications; and third, if field data shows timber laundering, communicate with the country of destination, particularly if they have a demand side policy.

\section{Demand side policies and "Good Faith"}

According to Peruvian legislation (Law 29763, Article 126): “All people are obligated, under the requirement of the forest authority, to prove the legal origin of any forest and wildlife product or species. All people who hold, transport and trade a forest or wildlife product or species whose legal origin cannot be proved under the authority requirement, is subject to seizure of the product, as well as the application of the sanctions defined by this law and its regulations, regardless of the knowledge or not of the illegal origin of the products".

The Peruvian law clearly defines that the key aspect is the "legal origin" and not the papers that accompany the product and which could be based on false information. It also makes it explicit that whoever holds, transport or trades the

28. Osinfor (October 2015). Resultados de las supervisiones y fiscalizaciones efectuadas por el Osinfor en el marco del Operativo Internacional "Operacion Amazonas 2014", p.9 and p.48. 29. For EIA's 2012 report, all the Osinfor data was obtained either in photocopies or pdf format. Now Osinfor has a publicly available database that gets updated daily: SIGO.

30. In a joint statement from November 2016, between Peru and the US foreign trade authorities, Peru committed to modify its timber exports documentation in order to include information that would allow to conduct effective traceability for the timber and timber products. Peru committed to implement this modification by the first quarter of 2017. It has not been implemented yet. For the joint statement, see: https: / / ustr.gov/about-us / policy-offices / press-office / press-releases / 2016/ november/ joint-statement-meetings-peru-us 
product has the responsibility to prove and answer for the origin of the product and, if the legal origin cannot be proved, whoever is in possession of the product is responsible, even if they did not know of the illegal origin of the product.

Exporters of Yacu Kallpa illegal timber, $2015^{31}$

\begin{tabular}{|c|c|c|c|c|c|c|c|c|c|}
\hline Peru exporter & $\begin{array}{l}\text { Volume ( } \\
\text { YK-2 }\end{array}$ & $\begin{array}{l}\left(m^{2}\right) \text { of illes } \\
\text { on ship } \\
\text { YK-4 }\end{array}$ & $\begin{array}{c}\text { gal timber } \\
\text { YK-5 }\end{array}$ & $\begin{array}{l}\text { Total } \\
\text { timber } \\
\text { verified } \\
\text { illegal (m') }\end{array}$ & $\begin{array}{l}\text { Total } \\
\text { timber not } \\
\text { verifited } \\
\text { (in') }\end{array}$ & $\begin{array}{l}\text { Total timber } \\
\text { verifled or } \\
\text { presumed } \\
\text { legal (m?) }\end{array}$ & $\begin{array}{l}\text { Grand Total } \\
\text { (verified illegal } \\
\text { or legal * not } \\
\text { verified) (m') }\end{array}$ & $\begin{array}{c}\text { \% } \\
\text { verified } \\
\text { iliegal of } \\
\text { total }\end{array}$ & $\begin{array}{c}\% \\
\text { werified } \\
\text { illegal of } \\
\text { werified }\end{array}$ \\
\hline INVERSIONESLA CROZASRLL & $3,282.78$ & $4,02.02$ & 2,74570 & $10,130,50$ & $\pi 23.362$ & 375,794 & $\pi, 62966$ & 8745 & $96.4 \%$ \\
\hline INVERSIONES WCA EIR.L. & 884.93 & 2.826 .86 & 2.735 .14 & 6.446 .92 & 177,155 & 591.907 & $7,215.98$ & 89.35 & $916 \mathrm{~s}$ \\
\hline CORPORACION INDUSTRIAL FOAESTAL SAC. & 719.95 & 1,42896 & 142.63 & 2.290 .74 & 890.793 & 257.489 & 3.429 .02 & $66.8 \mathrm{~s}$ & $89.9 \%$ \\
\hline SICO MACERASSAC. & 350.32 & 459.24 & 683.08 & 1,49264 & 12.434 & 229.44 & 1,73452 & $86, \%$ & 86.75 \\
\hline CORPORACIOON MADERERA LORETOSAC & 21.84 & 747.25 & 35717 & 126.25 & 48245 & & 1608.70 & $70.0 \mathrm{~K}$ & $100.0 \%$ \\
\hline TREALAY IOUITOS SAC. & 96.51 & 358.02 & 685.23 & 139.76 & 174019 & $2334 \pi$ & 1,48725 & 76.68 & $83.0 \%$ \\
\hline CORPORACON INECREST MC SAC. & & & & 1.27272 & & & 127.72 & $100.0 \%$ & $100.0 \%$ \\
\hline SCAVINO MADERASEIRL & & 58605 & 507.57 & $1,063,62$ & 822 & & $1,145: 82$ & 92.82 & $100.0 \%$ \\
\hline LAMINADOS Y KANUFACTURAS DE MADERA & 336.00 & 9000 & & 426.00 & 200 & 270 & $896 \infty 0$ & 475: & 6125 \\
\hline GREEN GOLD FORESTRY PERUSAC & & 4530 & & 45,30 & & 477.907 & 523.21 & $87 \%$ & $87 x$ \\
\hline EXMVAL EIRL. & 35208 & & & 35208 & $35.6 n$ & & 387.76 & $90.8 \%$ & $1000 \%$ \\
\hline INDUSTRIAS MACEX EIRL & 45.86 & 135.18 & 900 & $2 m .14$ & & & 277.4 & $100 \mathrm{os}$ & $1000 \mathrm{~s}$ \\
\hline MADERAS DE LA SELVA PERUANA SAC. & & 148.43 & & 148.43 & 36.632 & & 185.07 & 8025 & $1000 \%$ \\
\hline INDUSTRIALL MADERERA ZADOTE SA. & & 99.81 & & 99.81 & & 79.783 & 179.59 & $55.6 \%$ & 55.65 \\
\hline MADERAS IMPFEGNADAS TROPICALES SAC. & & & 38.6 & 38.16 & & & 38.16 & $1000 \%$ & $1000 \%$ \\
\hline Totals & $6,090.26$ & $10,996.31$ & $7,990.78$ & $26,355,06$ & $3,144.72$ & $2,515.79$ & $32,015.58$ & $82.3 \mathrm{~K}$ & 91.3\% \\
\hline
\end{tabular}

Chart info: This chart shows the amounts and percentages of illegally logged timber that could be documented for the three shipments of the Yacu Kallpa vessel - the one transporting the timber from Iquitos to Houston, with optional stops on the way in or out - that formed part of Operation Amazonas 2015. The chart was originally published in EIA's Moment of Truth in 2018.

This is actually compatible with what has been called "demand side policies", such as the United States' Lacey Act or the European Union Timber Regulations, which declare it illegal to import to their countries products harvested in violation of the country of origin laws. For these demand side laws, the issue at stake is the legal or illegal origin of the timber, despite what the accompanying documentation may claim. These norms are aimed at reinforcing the national legislation of the countries of origin, and also at making sure that the field is leveled for other exporters or importing country producers, with no illegal products coming to compete unfairly.

31. MOT page 36. 
When confronted with evidence documenting illegal timber in specific containers related to specific exporters and importers, such as from The Laundering Machine, Operation Amazonas, or Moment of Truth, the traders argue that they acquired the product "in good faith" and with official documents. It has to be clear to everyone that the illegal origin of the timber is one thing and the papers based on fake information that are used to launder that illegally logged timber quite another.

As was demonstrated a few years ago by a documentary produced by $\mathrm{Al}$ Jazeera, "Peru's Rotten Wood," 32 there is a non-secret market for papers with which to launder the timber. The papers are not fake, the papers are official, but they are based on fraudulent information and, therefore, are meaningless.

An undercover investigation conducted by the international NGO Global Witness, entitled "Buyers in Good Faith" 33 includes an undercover video ${ }^{34}$ that shows several of the timber traders involved in the Yacu Kallpa case bragging about dealing in illegal timber and claiming that everybody involved knows about it.

A more recent report by the NGO Center for International Environmental Law (CIEL), "Authorized to Steal," ${ }^{35}$ singles out the actors responsible throughout the supply chain for illegal timber, identifying names and including pictures of the forest engineers from the private sector that have been producing fake forest inventories, as well as of the regional government officers validating them and, therefore, facilitating the illegal timber trade and laundering.

At this point, with the extent of academic, journalistic and civil society publications available on the real situation of Peru's timber sector, no one linked to the sector can claim that they are not aware of the very high risk of illegality. The results of Operation Amazonas for 2015 show timber shipments from Peru to Mexico and the U.S. with percentages of illegality that fluctuate between $85 \%$ and $100 \% .{ }^{36}$

\section{Industry pushes back to interrupt traceability}

As soon as the effects of Operation Amazonas started resulting in legal actions in the U.S., Mexico, the Dominican Republic and Brazil, a part of the Peruvian timber industry began lobbying to weaken Peruvian timber regulations and institutions, starting with Osinfor. The data from Osinfor field verifications proved to be key in validating

32. Al Jazeera. "Peru's Rotten Wood". August 12, 2015. https:/ / www.aljazeera.com/programmes / peopleandpower / 2015/08/ peru-rotten-wood-150812105020949.html

33. Global Witness. "Buyers in Good Faith". https://www.globalwitness.org/en/campaigns / forests / buyers-good-faith/. November 2017.

34. Global Witness. "Peruvian Timber Exporters Expose - the Video Evidence" https: / www. globalwitness.org / en / campaigns / forests / peruvian-timber-exporters-expose-the-video-evidence/ November 2017.

ing-the-independence-of-osinfor

35. CIEL. "Authorized toSteal".July 2019.https:/ / www.ciel.org/ wp-content/up-loads/2019/07/ Authorized-to-Steal-July-2019.pdf35.

36. MOT, p. 36 
or not the real legal origin of a timber product and, according to the industry, Osinfor was being too severe. When it became clear that the President of Osinfor at that time was not willing to soften the implementation of the law, they began lobbying to get rid of him and to remove the institution's independence. In January 2016, Osinfor's president had his contract terminated abruptly and without cause. ${ }^{37}$ The argument given by the executive branch in the midst of a strong reaction from civil society, the media and even international cooperation, was that it was time to open a new public process to select a new president. By July 2019, three and a half years later, the government had still not appointed a formal new president for Osinfor.

During those three and a half years, Osinfor has also suffered many threats to weaken and reduce the institution, ${ }^{38}$ culminating eventually, in late 2018, in its independence being removed when it was relocated from being an independent body under the Presidency of the Council of Ministers (PCM) to the Ministry of MINAM, further creating a number of immediate and potential conflicts of interest. ${ }^{39}$ The interim President of Osinfor and his closest advisors submitted a letter of resignation explaining that the relocation implied a loss of independence that they could not accept. There was also a strong reaction from the media, civil society and international cooperation but, for a while, the Peruvian government stood strong. Osinfor's independence was one of the commitments of the U.S.-Peru TPA, however, so the U.S. started a dispute under the trade agreement, demanding Osinfor be returned to the PCM. ${ }^{40}$ This did eventually happen. Now, however, there is a new threat hanging over Osinfor: a regulation that had never been implemented, that allowed Osinfor to hire third-party field supervisors for very specific situations and under very specific procedures, has been modified to make it more of an everyday option with no special requirements. ${ }^{41}$ Given the previous systematic

37. EIA. "EIA denounces termination of Peruvian Forest Oversight Body President". January 15, 2016. https: / / eia-global.org/ press-releases/eia-denounces-termination-of-peruvian-forest-oversight-body-president

EIA. "EIA: Peru must guarantee safety of former forest inspector and his family, verify legal origin of timber exports. April 19, 2017. https://eia-global.org/press-releases/peru-must-guarantee-safety-for-former-forest-inspector

38. EIA. "Alert: Peruvian government threatening the independence of Osinfor". September 12, 2018. https://eia-global.org/press-releases/alert-peruvian-government-threatening-the-independence-of-osinfor

39. EIA. "Alert: The Peruvian government backs down in the ght against illegal logging". December 18, 2018. https: / / eia-global.org/ press-releases / 20181218-osinfor-pr-en

EIA. "Peru's ght against illegal timber trade at risk as authorities weaken rules and regulations". February 7, 2018. https:/ / eia-global.org/press-releases/perus- ght-against-illegaltimber-trade-at-risk-as-authorities-weaken-rules-and-regulations

40. USTR. “USTR Requests First-Ever Environment Consultations Under the U.S.-Peru Trade Promotion Agreement (PTPA)". January 4, 2019. https: / / ustr.gov / about-us / policy-o ces / press-office/ press-releases / 2019/january/ustr-requests-first-ever 41. Peru. Decreto Supremo 126-2019-PCM. https: / / www.gob.pe/institucion/ pcm/ normaslegales / 285385-126-2019-pcm July 12, 2019 
attempts to weaken and control Osinfor, there is a valid concern as to who will be hired and how. If an interested party can introduce a number of independent field supervisors, it could potentially control the results of the field reports. This is again a very dangerous decision, at a critical time.

Chart info: This chart, originally published as part of Moment of Truth, shows the analysis of 2,427 transport guides (GTF) that were provided by timber exporters to Serfor as evidence of the origin of their timber products to be exported from the Pacific port of Callao to different destinations around the world. This data corresponds to 2015 and was obtained from Serfor. When EIA requested similar data for 2016 and 2017, the official response was that it was not being collected any more. Crosschecking the GTF information with Osinfor's field verifications, it is clear that the chain of custody of most of the Peruvian exporters is contaminated with illegal timber. A Red GTF corresponds to a PO that Osinfor has identified as a source of timber laundering. A Green GTF corresponds to a PO that justifies a legal origin. The risk categories were developed by EIA, according to the methodology explained on the attached chart. These results may be the reason why the industry and Serfor were lobbying to eliminate the data that would allow this analysis to be updated. ${ }^{42}$

\section{Risk categories for point-of-harvest papers in Callao 2015 data}

\begin{tabular}{|c|c|c|}
\hline $\begin{array}{l}\text { Total GTFs not supervised } \\
\text { or undefined }\end{array}$ & Factors considered for risk level & 1636 \\
\hline Low Risk & all the previously supervised POAs are in green & $36 \%$ \\
\hline Mid Risk & $\begin{array}{l}\text { at least one and up to } 50 \% \text { of previously supervised POAs are in red } \\
\text { the logging contract has never been supervised before } \\
\text { information on GTF submitted by the exporter is illegible }\end{array}$ & $20 \%$ \\
\hline High Risk & $\begin{array}{l}\text { over } 50 \% \text { of the previously supervised POAs are in red } \\
\text { the logging contract has been annulled by the authorities due to } \\
\text { severe infractions } \\
\text { the logging contract does not exist in SIGO } \\
\text { there is no information about the logging contract or the GTF }\end{array}$ & $44 \%$ \\
\hline
\end{tabular}

42. MOT. Methodology chart: page 57. Exporters chart: page 58. 


\section{Exporters of illegal and high-risk timber}

\begin{tabular}{|c|c|c|c|c|c|c|c|}
\hline & EXPORTER & \# GTF & Red GTF & Green GTF & \# Low risk & \# Mid risk & \# High risk \\
\hline 1 & Maderera Bozovich SAC & 419 & 62 & 76 & 94 & 88 & 99 \\
\hline 2 & Inversiones La Oroza SRL & 271 & 57 & 38 & 39 & 52 & 85 \\
\hline 3 & Peruvian Flooring SAC & 219 & 5 & 26 & 159 & 15 & 14 \\
\hline 4 & Inversiones Técnicas Maderables SAC & 112 & 4 & 46 & 34 & 10 & 18 \\
\hline 5 & Consorcio Maderero SAC & 97 & 17 & 3 & 2 & 5 & 70 \\
\hline 6 & Maderera Rio Acre SAC & 90 & & & 88 & & 2 \\
\hline 7 & Negociación Maderera Travi Satipo SRL & 71 & & 40 & 2 & 29 & \\
\hline 8 & Maderera Pacífico International SRL & 68 & 36 & 16 & 3 & 5 & 8 \\
\hline 9 & Maderera Diaisi EIRL & 67 & 8 & & 4 & 5 & 50 \\
\hline 10 & Maderera Cinco Estrellas SAC & 65 & 34 & 2 & & 7 & 22 \\
\hline 11 & JR Muye Investment SAC & 63 & 16 & 7 & & 3 & 37 \\
\hline 12 & Industria Forestal Huayruro SAC & 51 & 4 & 40 & 1 & & 6 \\
\hline 13 & Hermanos Forestal SAC & 45 & 20 & & & & 25 \\
\hline 14 & E \& J Matthei Maderas del Perú SA & 45 & 11 & 3 & 17 & 2 & 12 \\
\hline 15 & Logistica Maderera Selva SCRL & 45 & 7 & 1 & 2 & 4 & 31 \\
\hline 16 & Lumat Maderas SAC & 41 & 2 & 9 & 4 & 2 & 24 \\
\hline 17 & Maderap SAC & 40 & 12 & 3 & 2 & 13 & 10 \\
\hline 18 & Industrias Madex EIRL & 39 & 13 & 5 & & 11 & 10 \\
\hline 19 & Arbe Lumber SAC & 38 & 2 & 3 & 15 & 6 & 12 \\
\hline 20 & Aserradero Espinoza SA & 37 & & & 37 & & \\
\hline 21 & Grupo Vargas Negocios Amazónicos SAC & 31 & 1 & 3 & 9 & & 18 \\
\hline 22 & SUTAY Company SRL & 30 & 13 & 2 & 3 & & 12 \\
\hline 23 & Corporación Maderera Loreto SAC & 27 & 7 & 3 & 4 & 4 & 9 \\
\hline 24 & Peruvian Woods Company EIRL & 27 & 2 & 8 & 7 & 4 & 6 \\
\hline 25 & Olinda Shuña Perez & 23 & 5 & 6 & & 5 & 7 \\
\hline 26 & Corporación Industrial Forestal SAC & 25 & 11 & & & 10 & 4 \\
\hline 27 & Corporación Forestal Claudita SAC & 21 & & & 21 & & \\
\hline 28 & IMK Maderas SAC & 20 & & & 6 & 3 & 11 \\
\hline 29 & Inversiones WCA EIRL & 20 & 5 & & & 3 & 12 \\
\hline 30 & Maderera Vulcano SAC & 20 & 1 & 5 & 4 & 3 & 7 \\
\hline 31 & KMU Peru SAC & 19 & 3 & 8 & 3 & 1 & 4 \\
\hline 32 & Industrial Ucayali SAC & 17 & & & 7 & 1 & 9 \\
\hline 33 & Casa Ideal Constructores SAC & 17 & 3 & 1 & 2 & 7 & 4 \\
\hline 34 & Tender SAC & 16 & 1 & 5 & & 3 & 7 \\
\hline 35 & King Forest SAC & 16 & & 9 & & 1 & 6 \\
\hline 36 & Santa Angela Group SAC & 14 & 3 & 7 & 2 & & 2 \\
\hline 37 & Industria Forestal Iquitos SRL & 12 & 1 & 1 & & & 10 \\
\hline 38 & Aserradero Denis SAC & 12 & 1 & & 2 & 3 & 6 \\
\hline 39 & Peruvian International Trading Co., Ltd. & 11 & & & 10 & 1 & \\
\hline 40 & Podium Forestal SAC & 10 & 6 & 2 & & & 2 \\
\hline 41 & International General Trade SAC & 10 & & 1 & & 3 & 6 \\
\hline 42 & Weiman SAC & 9 & 6 & & 2 & 1 & \\
\hline 43 & Super Pisos SA & 9 & & & 2 & & 7 \\
\hline 44 & Global Wood SAC & 8 & & 4 & 4 & & \\
\hline 45 & LH Timber Company SAC & 7 & 3 & & & & 4 \\
\hline 46 & Aserradero Victoria SAC & 6 & & & & 2 & 4 \\
\hline 47 & Comercial Maderera del Cuadro SAC & 6 & & & & & 6 \\
\hline 48 & Comercio Internacional Amazónico EIRL & 6 & 3 & & & 1 & 2 \\
\hline 49 & Maderera DGP SAC & 6 & 4 & & & & 2 \\
\hline 50 & Hongxing SAC & 5 & & 3 & & 1 & 1 \\
\hline 51 & DMEXP SAC & 5 & & & 1 & & 4 \\
\hline
\end{tabular}




\begin{tabular}{|c|c|c|c|c|c|c|c|}
\hline 52 & NCS American Forestal SAC & 5 & 2 & & & & 3 \\
\hline 53 & Inversiones de la Selva Peruana Nathaly SAC & 4 & & 4 & & & \\
\hline 54 & Enterprise Forestal e Inmobiliaria SAC & 4 & 1 & & 2 & & 1 \\
\hline 55 & Pacific Wood SAC & 4 & & & 4 & & \\
\hline 56 & Grupo WAYUAN SAC & 4 & & & & 3 & 1 \\
\hline 57 & International Santa Fe SRL & 4 & 1 & 1 & & 1 & 1 \\
\hline 58 & Corporación Tori SAC & 2 & & & & 1 & 1 \\
\hline 59 & Green Gold Forestry Peru SAC & 2 & 2 & & & & \\
\hline 60 & Global Wood Company SAC & 2 & 1 & & & 1 & \\
\hline 61 & Inversiones Generales Ximjolo SAC & 2 & & & & 2 & \\
\hline 62 & CKD Trading SAC & 1 & 1 & & & & \\
\hline 63 & King Lumber Company SAC & 1 & & & 1 & & \\
\hline 64 & Triplay Iquitos SAC & 1 & & & & & 1 \\
\hline 65 & Metals Precious SAC & 1 & 1 & & & & \\
\hline 66 & Ego Wood SAC & 1 & 1 & & & & \\
\hline \multirow[t]{2}{*}{67} & LOEB \& Ximena EIRL & 1 & 1 & & & & \\
\hline & Grand Total & 2427 & 400 & 391 & 599 & 322 & 715 \\
\hline & $\%$ out of total & & 17 & 16 & 25 & 13 & 29 \\
\hline
\end{tabular}

Source: Callao 2015 database

Over the last decade in Peru, the way to verify legal origin has been by requesting from the trader or the exporter the documents that connect their timber to the point of harvest (timber transport guides, GTF in Spanish) and then crosschecking that information with Osinfor's field verification of the real situation at the point of harvest. After the impact of Operation Amazonas - in addition to the attempts to weaken and control Osinfor - the Peruvian timber industry and the Peruvian forest authority, Serfor, focused on dismantling traceability from the point of harvest. ${ }^{1}$ Since they were facing problems due to the evidence that kept demonstrating that there was illegally logged timber in their chain of custody, instead of cleaning it up, the easy way out seems to have been to try to dismantle any options to connect sawn timber to its point of harvest.

\section{Blurring the origin}

Initially, both Serfor and the industry (the association of exporters, ADEX, and the national society of the industry, SNI) claimed that traceability to connect sawn timber to the point of harvest was simply impossible. ${ }^{44}$ Soon after, they began to promote a new approach that divided traceability into two phases: a first phase con-

44. Letter signed by Erik Fischer Llanos (ADEX) and Alfredo Biasevich Barreto (SNI) addressed to Walter Cárdenas Mendoza, Superintendent of Sunat, ref. modifications to DAM format. March 29, 2017. https: / content.eia-global.org/assets/2017/ momentoftruth/25.+CARTA+ADEX+-+SNI-+TRAZABILIDAD.pdf

Serfor comments on Sunat's proposed revisions to DAM. March 29, 2017. https: / / content. eia-global.org/ assets / 2017 / momentoftruth / 26.+Informe+Tecnico+034-2017-SERFOR-DGPCFFS-DPR.pdf 
sisting of point of harvest traceability from the forest to the sawmill, and a second phase that eliminates the connection with point of harvest as soon as the timber arrives at the sawmill, and only continues with what is called a mass balance approach (comparing the volumes of what comes in and what goes out) so that there is no way to connect the timber leaving the sawmill with its point of harvest. Considering that Peru only allows for the export of timber that has already been sawn, this would mean that no piece of timber coming out of the country could be linked to point of harvest and, therefore, to a verified legal (or illegal) origin.

It is no secret that several of the institutions fighting illegal logging and its trade in Peru have opposed this approach in multiple meetings and even with letters and written comments to Serfor. Most recently, Osinfor produced a thorough report - sent to Serfor and the FEMA - asserting that the new (but not yet implemented) 2017 Libro de Operaciones (the operational books that keep records of what is being harvested or produced, recording what comes in and what goes out) runs directly counter to the Forest Law and its regulations. The report also concludes that "given the public evidence of illegality and informality in the sector, where a significant volume of non-justified timber arrives at the primary transformation plants, the mass balance approach will not guarantee legal origin of the timber from point of harvest; on the contrary, it will prevent the traceability of the whole chain of custody". ${ }^{45}$ Osinfor has also questioned the yield formulae being applied for the mass balance approach, arguing that they do not correspond to real yields and allow for the laundering of illegal timber. The yield formulae are the percentages used to estimate what volume of sawn timber should result from processing a given volume of round timber or logs. If the yield formulae are too high, it means there is room to add more unregistered illegal logs to the mix. "Serfor's approach could create a perverse incentive for the continuity of illegal practices, since it will jeopardize the criminal investigations being conducted by the FEMA and the police to detect those responsible for environmental crimes and will leave the door open to illegalities and informalities that have the appearance of legality." 46

Additionally, in its report, Osinfor also explains that, after comparing the data from their field verifications with the data from Serfor's publication, "Peru Forestry in Numbers, $2015^{\prime \prime},{ }^{47}$ it is evident that over $50 \%$ of the timber that leaves the sawmills is coming from illegal harvesting. The same publication by Serfor also claims that $84 \%$ of the national timber production for 2015 was sawn timber -

45. Osinfor. Informe N. 027-2018-OSINFOR/08.2. April 17, 2018. Included in Oficio N. 058-2018-OSINFOR/01.1, addressed to FEMA's coordinator, Flor de María Vega, April 25, 2018 and in Oficio N. 062-2018-OSINFOR/01.1, addressed to Serfor's Executive Director, John Leigh, April 30, 2018.

46. Osinfor. Informe N. 027-2018-OSINFOR/08.2. April 17, 2018. Included in Oficio N. 058-2018-OSINFOR/01.1, addressed to FEMA's coordinator, Flor de María Vega, April 25, 2018 and in Oficio N. 062-2018-OSINFOR/01.1, addressed to Serfor's Executive Director, John Leigh, April 30, 2018.

47. Serfor. Anuario Forestal "Perú Forestal en Números 2015”. Lima, Peru. December 2016. 
and not the more elaborate products that part of the industry argues would make traceability more challenging. Osinfor has expressed its concerns given that its field verifications for 2017 found that $67 \%$ of the timber being mobilized was of illegal origin and could be laundered by the system at any moment. A few months after Osinfor produced these strong documents opposing Serfor and the industry, the independence of the institution was removed by relocating it under the Ministry of the Environment. ${ }^{48}$

\section{Jeopardizing the Peruvian timber sector}

Serfor's document $N^{\circ}$ 003-2018-MINAGRI-SERFOR-DGPCFFS/DPC claims that Osinfor's traceability model is not feasible. It is, however, hard to understand how and why Serfor started arguing in early 2017 that it was impossible to connect point of harvest to a shipment of timber to be exported given that, in mid-2016, the Peruvian government had produced a special report for the U.S. government, in response to a formal request for legal origin verification for a timber shipment based on a mechanism defined by the U.S. - Peru bilateral trade agreement. ${ }^{49}$ For that report, the Peruvian authorities - including Serfor - requested the documentation on point of harvest from the exporter and verified legal origin by going to the field to check the situation of the specific plots. Serfor still has to explain what changed so radically between mid-2016 and early 2017 to make this traceability of legal origin suddenly impossible.

With a system that can only connect timber exports to the sawmill and not to point of harvest, and given the multiple concerns expressed by Osinfor and the other Peruvian authorities regarding the proposed model, Peruvian timber could be banned from international markets that have higher standards and which are requesting verification of legal origin for the timber being imported, as is the case of the United States and the European Union, among others. Even China could apply some restrictions, given that an important amount of the timber this country imports is not for local consumption but for processing and re-export to countries with high legal standards. If China wants to export to those markets, they may have to demonstrate that no illegal timber is contaminating their chain of custody.

49. While the report produced by the Peruvian government was not made public, the U.S. government produced a public briefing reacting to the Peruvian government's report and commenting some of its results. See the US government briefing here: Interagency Committee on Trade in Timber Products from Peru. "Statement Regarding July 2016 Timber Verification Report From Peru". August 17, 2016 https:/ / ustr.gov/ sites/default/files/Timber-Committee-Report-8172016.pdf See the letter from the U.S. government requesting the Peruvian government to conduct the verification here: United States Trade Representative. “USTR Requests Peru Timber Verification”. February 26, 2016. https: / / ustr.gov / about-us / policy-offices / press-office / press-releases / 2016 / february / ustr-requests-peru-timber 
The U.S. government has already used the tools of the U.S.-Peru Trade Promotion Agreement included in the Annex on Forest Sector Governance ${ }^{50}$ to demand the Peruvian government verify the legal origin of timber shipments being exported from Peru to the U.S. The results have been concerning, and the USTR has already banned two of the companies identified with illegal timber in their chain of custody. The most recent public statements of the USTR have also expressed increasing frustration over the Peruvian government's failure to do enough to stop the illegal timber trade, ${ }^{51}$ despite over 90 million dollars having been received from the U.S. government in cooperation for forest sector governance. ${ }^{52}$ The reality, however, is that many more companies that are exporting to the U.S. have been documented as trading illegally logged timber. ${ }^{53}$ Will the USTR end up banning all those companies? Will the USTR at some point decide to block all timber from Peru? Will other countries start following the lead of the U.S. and begin banning Peruvian timber exporters as well? Is Peru willing to run the risk of being banned from the international timber markets in order to benefit a few questionable short-sighted businesses that are not even bringing real development to the local people?

\section{Conclusions and recommendations}

We all understand that eliminating illegal logging is not an easy task. Stepping back from the improvements achieved through the efforts of the last decade is clearly not a valid or reasonable option for Peru, however. It is crucial for the future of Peru's forest sector that the government continues to support the independent institutions that have been key in publicly known cases (Osinfor, FEMA, Sunat, Procuraduría MINAM), making sure that all of them - and not just one - keep implementing a system of checks and balances over the private and public actors involved, while stepping up with a strong position against any attempts to weaken effective traceability.

50. US-Peru Trade Promotion Agreement. Chapter 18. Annex 18.3.4 Annex on Forest Sector Governance. https://ustr.gov/sites/default/files/uploads/agreements / fta / peru/asset_ upload_file953_9541.pdf April 12, 2006.

51. As examples, see: July 2019: https://ustr.gov/about-us/policy-offices/press-office/ press-releases/2019/july/ustr-announces-enforcement-action January 2019: https://ustr. gov / about-us / policy-offices / press-office / press-releases / 2019/ january / ustr-requestsfirst-ever October 2017: https: / / ustr.gov / about-us / policy-offices/ press-office/ press-releases / 2017 / october/ustr-announces-unprecedented-action August 2016: https://ustr.gov/ about-us / policy-offices / press-office / press-releases / 2016 / august/ us-timber-committee-reacts-peru-timber-verification

Also see: EIA “U.S. Government report confirms imports of illegal timber from Peru. August 18, 2016. https://eia-global.org/press-releases/us-government-report-confirms-imports-of-illegal-timber-from-peru

52. U.S. Trade Representative Michael Froman. “Combatting illegal timber trade in Peru: views from Ucayali." 2016. https:// ustr.gov/about-us/policy-offices/press-office/ blog/2016/may/combatting-illegal-timber-trade-views-from-ucayali-peru

53. For some names of exporters and importers trading illegally logged timber, check Moment of Truth, chapters 4 and 7. 
Illegal timber is not something that one can hide in a suitcase and take out of the country without anyone noticing. One has to be able to launder the illegal timber with documents that simulate legality. The number of individuals in Peru facilitating the production of documents with which to launder illegal timber number a couple of hundred and are easy to identify. Targeting these actors with strong dissuasive sanctions would be a straightforward and low cost process for the Peruvian government. It is hard to understand why most of them continue to act with impunity, in spite of the abundance of public information available from governmental agencies, civil society investigative reports and the media.

Alongside this, traceability and transparency must be promoted in a way that can incorporate many more hands and brains in the fight against illegal activities in the Amazon. A traceability system based on easy to use applications, and which allow citizens to monitor timber trucks as they pass by on the highway, for example, is an alternative that has achieved a high level of engagement in places such as Romania, ${ }^{54}$ far distant from Peru but similar in that their civil society is also tired of the flagrant corruption and forest destruction. The indigenous communities whose forests are being logged by third parties that are harvesting many times more than allowed or in places other than allowed and not paying the fees to the government, often have to deal with illegal logging scams and, in addition, receive sanctions from the government. If they had a simple app to develop a forest inventory that they could then monitor from their own communities, several of these issues could be prevented or solved. Different NGOs around the world - including EIA - are working in coordination with local actors to develop these kinds of tool which, hopefully, will also be embraced by local and national authorities.

On May $2^{\text {nd }}$ 2018, when Vice President Martin Vizcarra had just assumed the Presidency of Peru after his predecessor was removed in the midst of a corruption scandal, Vizcarra's first President of the Cabinet of Ministers, Cesar Villanueva, stated in his first speech to the Peruvian Congress that "the dirty money coming into our economy is no longer coming only from corruption and drug dealing. Now it is also coming from illegal mining and illegal logging. These illegal activities have started to take over our territory and to penetrate politics due to the lack of a State capable of bringing order, basic services and development opportunities to our regions." ${ }^{55}$ It sounded promising, as if the new government were planning on taking action against these mafias that are taking over the country. So far, however, the country has seen no sign of any effective confrontation. Peru still lacks the motivation of a determined political will, from the highest level of government, to

54. Micu, Bogdan. TEDxBucarest. "Using technology to fight illegal logging." May 2017. https: / / www.youtube.com/watch? $\mathrm{v}=\mathrm{fMhHymBa1KE}$

55. Villanueva, Cesar. May 2, 2018. Speech at Peruvian Congress. http:/ / www.pcm.gob.pe/ wp-content / uploads / 2018/05/ discurso-de-investidura-del-presidente-del-consejo-de-ministros-cesar-villanueva-ante-el-congreso-de-la-republica.pdf 
empower and reinforce the work of a handful of brave officers who are risking their careers and theirs lives to fight Peru's still flagrant illegal timber trade.

Eliminating pieces of the jigsaw in order to blur the distinction between legal and illegal timber will only backfire. The new forest authorities in the country seem to have understood this situation and now appear to be working in this direction. The long-term vision - implying a sustainable use of the natural forests and resources for the sake of future generations, the environment and the planet - will hopefully win over the short-sighted one - allowing the industry and exporters to do what they want now, at the cost of environmental destruction and violations of human rights. Peru must understand that, for the sake of its forests, but also for the sake of its timber industry, transparency is the only route.

\section{Illegal logging in Peru's Criminal Code}

These are some of the most relevant articles in Peru's Criminal Code regarding illegal logging and timber laundering.

Article 310.- Crimes against forests and forest formations: Anyone who, without a permit, licence, authorization or concession granted by a competent authority, destroys, burns, damages or fells, in whole or in part, forests or other forest formations, be they natural or plantation, shall be punished with a prison sentence of no less than four and no more than six years and with community service of forty to eighty days.

\section{Article 310-A.- Illegal trafficking in timber forest products}

Anyone who obtains, gathers, stores, processes, transports, conceals, guards, markets, loads, offloads, imports, exports or re-exports timber forest products or specimens when they are aware of or can assume their illegal origin shall be punished with a prison sentence of no less than four and no more than six years and between one hundred and six hundred day fines.

\section{Article 427.-Falsification of documents ${ }^{56}$}

Anyone who, in whole or in part, produces a false document or falsifies a true document such that it may give rise to a right or duty or serve to prove an event, with the aim of using the document, shall be punished, if any harm results from

56. It is important to note here that harm to the legal asset may be multifaceted, as in the case of environmental crimes; and that it is infringing, in a more concrete sense, the reliability and security of legal traffic, which deserves special attention, given that the aim is to try to protect something with this legal asset which, although by definition is more tangible and less generic than can be understood by public faith, is also a way of assuming a certain moment of consummation. See https://legis.pe/en-que-momento-se-consuma-el-delitode-falsedad-documental-legis-pe / 
its use, to a prison sentence of no less than two and no more than 10 years and between thirty and ninety day fines if it is a public document, public record, original title or any other document transmissible by endorsement or to the bearer and with a prison sentence of no less than two and no more than four years and one hundred and eighty to three hundred and sixty-five day fines if it is a private document.

Anyone who uses a false or falsified document as if it were legitimate, if any harm results from its use, shall be punished, where appropriate, by the same penalties.

\section{Article 428.-Ideological falsehood}

Anyone who inserts or has inserted, in a public instrument, false declarations concerning events that are intended to be proven with said document, with the aim of using it as if the declaration were true, shall be punished, if any harm results from its use, with a prison sentence of no less than three and no more than six years and with one hundred and eighty to three hundred and sixty-five day fines.

Anyone who uses the document as if the content were accurate, if any harm results from its use, shall be punished, where appropriate, with the same penalties. 


\section{FORESTS AND INDIGENOUS PEOPLES FACING CLIMATE CHANGE AND GLOBALISATION}

\section{José Álvarez Alonso}

The way Peru views the Amazon (from Lima and other coastal and Andean cities) has traditionally been through the prism of its agricultural and livestock farming potential, its land, and with a clear policy of expanding the agricultural frontier. This has been followed by various waves of extractive activity relating to one commodity or another, depending on market demand at the time: rubber, animal skins, fine woods, oil, gold... The forests and their inhabitants, the Amazonian peoples, have been either ignored or seen as a hindrance to a development model intent on replicating coastal and Andean methods of production.

Several million hectares of deforestation later, with hundreds of millions spent on penetrative highways, unpaid agricultural loans and hundreds of failed development projects, there are growing questions as to this development model, not only from the academic community but also from the Amazonian communities themselves. Ever more frequent and destructive "natural disasters" (floods, drought, landslides), a result of climate change expedited by unbridled deforestation, are a reminder of the externalities of an anti-Amazonian development model.

President Belaunde once described the Amazon as "the breadbasket of Peru". He was fascinated by what he had seen in central Huallaga: wide expanses of fertile plain in which different cash crops were thriving in place of virgin forest. His vision of Amazonian development can be summarised in the phrase "rice and steak", in which he envisaged extensive rice paddies alongside pastureland dotted with plump cattle... During both his first and second term in office, he vigorously promoted the settlement of the Amazon by Andean settlers under the slogan "land with no men for men with no land", and he promoted highway construction to support this, particularly the Marginal de la Selva Highway. And yet the deep, fertile alluvial soils of central Huallaga are not the norm but rather the exception in the Peruvian Amazon: most of the non-floodplain lands are acidic, poor in nutrients and with a very low cation exchange capacity; add this to high rainfall and temperatures and relatively high humidity and the land become rather inappropriate for agriculture or cattle rearing.

The most serious error in Belaunde's vision, however, was not productive but social: the so-called "myth of the empty Amazon", in addition to the "savage opposed to development", has resulted in the most perverse of all Amazonian myths. It has had a tremendous impact on the indigenous communities and continues to do so to this day. This fateful vision can be summarised in the words 
of Belaunde himself, published in the daily newspaper Expreso in 1981: "It is absurd to think that places with 70 or 80,000 hectares should be set aside for 20 or 30 native families. These families live a primitive life and we need to re-settle them on adequate land for permanent crop growing..." (cited by Trapnell, 1982).

Belaunde was not, however, the only one to make such mistakes. The recent history of the continental Amazon is a story of resounding failures on the part of those attempting to establish a development model copied from temperate regions. They have squandered fortunes and destroyed vast forests in the belief that cash crops could be grown in the Amazon as done at other latitudes. The first and possibly most famous case was that of the car magnate Henry Ford, the richest man in the world at the time, who tried to establish an enormous plantation and industrial rubber plant in the Brazilian Amazon at the end of the 1920s: the dystopian Fordlandia. The remains of this debacle can still be seen in the middle of the forest to this day (Grandin 2010).

Almost 40 years later, another American magnate, Daniel K. Ludwig (the richest man in the world in the mid-1970s), also resoundingly failed in his attempts to establish the largest pulp mill in the world at the mouth of the Amazon: the Jari Project. The Brazilian government sold him $6,500 \mathrm{~km}^{2}$ of forest, much of which he replaced with Gmelina arbórea, a tree native to Asia, in addition to pine and eucalyptus. Ludwig built $4,000 \mathrm{~km}$ of roads, $70 \mathrm{~km}$ of railway lines and imported an enormous floating pulp mill from Japan (valued at USD 269 million).

After little more than two decades and more than a billion dollars later, and despite state-of-the-art technology introduced both into the plantations and the processing plants, the project had virtually collapsed. Ludwig transferred ownership to a group of Brazilian businessmen free of charge, who in return took over hundreds of millions of dollars of debt. The project is described by experts as one of the most shameful failures in the history of $20^{\text {th }}$ century engineering (McIntyre, 1980).

\section{The "Amazonian Factor"}

A number of experts believe that the failure of these and other Amazonian development projects is largely down to the so-called "Amazonian Factor": the combined effect of poor nutrients and high soil acidity, high precipitation (which washes both nutrients and agrochemicals out of the vegetation and soil), relatively high humidity (which encourages the proliferation of certain pests, particularly fungi), high temperatures, and plagues of insects brought on by the previous factors, not to mention a wide range of tropical diseases.

Today, an additional series of constraints has been added to the "Amazonian Factor", further limiting the agribusiness development model that has been imposed on the Amazon. There is what can be known as the "Climate Change Factor", due to international commitments made to protect the Amazon forest in order to reduce $\mathrm{CO}_{2}$ emissions; the "Market Factor" caused by consumer trends 
and international market demand, which increasingly restricts the purchase of products from deforested areas and which prioritises natural products that have a low carbon footprint and meets socio-environmental standards. And, in the case of the Peruvian Amazon, where indigenous communities and Amazon river dwellers make up the majority of the population, there is also what can be known as the "Socio-cultural Factor". A brief overview of these factors will be discussed in the following paragraphs.

\section{Climate Change Factor}

The commitments made by Peru and other countries to reduce $\mathrm{CO}_{2}$ emissions seriously limit any project or programme from expanding the agricultural frontier at the expense of the forest. There is ever greater evidence of the role the Amazonian forests play in mitigating global climate change: as a carbon sink, as a provider of ecosystem services - protecting the soil and regulating hemispheric climate, for example, not to mention the fact that the Amazon basin is home to $20 \%$ of the planet's unfrozen fresh water and the most extraordinary biodiversity.

Peru has undertaken to reduce deforestation and to preserve its Amazonian forests through various international agreements (including Rio +20 and the Paris Climate Agreement). The new Forest and Wildlife Law, Law No. 29763, protects forestry heritage as a whole, prohibiting its use for agriculture, and establishes very clear controls relating to any change of use, which must be approved by the Ministry of the Environment (MINAM).

\section{Market/Globalisation Factor}

There are still some people in Peru (happily a declining number) who continue to dream of large investments and enormous monocrop plantations in the Amazon. They circulate "official" maps showing the oil palm corridors: the Ministry of Agriculture had planned to establish more than ten million hectares some years back between Loreto, Ucayali, San Martín and Huánuco, where there are now some 60,000 hectares of oil palm. The new forestry / environmental regulations and Peru's international commitments to reduce carbon emissions, combined with the low productivity of the plantations in most of the areas where they have been promoted, not to mention ever more demanding markets, have brought many of these projects to a halt.

As a consequence, both the "National Sustainable Palm Oil Development Plan", approved by MINAGRI in 2016, and the "National Sustainable Palm Oil Development Plan 2017-2022", promoted by the National Palm Oil Board - Jun Palma Perú, include measures to ensure crop sustainability, to comply with Peru's strict forestry regulations (protecting the forests) and to meet international standards that will enable access to markets. The palm oil producers are promoting RSPO certification (Roundtable on Sustainable Palm Oil), which includes clear actions to prevent the felling of forests. 
At the start of 2017, representatives of Grupo Palmas, owner of the largest oil palm plantations in Peru, and which until recently had plans to extend their plantations in Manití (Lower Amazon) and Tierra Blanca (Lower Ucayali), submitted their "sustainable palm" plan to the Ministry of the Environment. In addition to clearly establishing that they would not extend their plantations at the expense of primary forest nor purchase land from farmers who had done the same (they had been reported for this practice in the past), this included measures to "compensate" for the loss of forests caused by their plantations in the Shanusi River basin, on the border with Loreto and Ucayali, through reforestation and support for forest conservation.

This is not a passing whim for a company that is seeking to do some "greenwashing": most large multinational food and cosmetics companies have been making similar commitments and taking measures to guarantee the sustainability of their supply chains and to avoid negative environmental and social impacts for years. The first was Nestlé, who clearly learned from the lesson of European consumers' relentless boycotting in response to their promotion of milk formula in place of breastmilk, and then of chocolate made from cocoa produced in African plantations using child labour. Since 2010, Nestlé has stopped purchasing products derived from the felling of forests, and from organisations using child labour, among other things.

Other large companies, including Cargill, Unilever, Danone, Kraft and PepsiCo have followed suit, making similar commitments. It will very soon be extremely difficult for any company that fells tropical forests to find a market for their palm oil, cocoa, coffee or any other commodity. This is a global trend in both food and cosmetic industries and is in response to consumer pressure.

\section{Socio-cultural Factor}

In a study conducted by the PROCREL Support Project (Programme of Support to Regional Conservation Areas in Loreto) in 2011, it was shown that the majority of the oil palm plantation workers in Loreto and San Martín were not local but of Andean origin (primarily from the northern mountains, including the Piura mountains). When management were asked why they were not hiring local staff they gave evasive responses about the "job profile".

The anthropologist Jorge Gasché has studied the Amazonian "profile" in some depth and has shed light on the myth of the "lazy" indigenous person: his conclusion is that Amazonian peoples are not "farmers" but rather "forest dwellers", managing a diverse ecosystem in which the key resources for their subsistence (bush meat, fish, fruit) are largely unpredictable... (Gasché \& Vela, 2012). Their activities are therefore diversified, and their traditional strategies for ensuring their future and for reducing uncertainty have been not to accumulate (land, cattle, etc.) but rather to establish lasting relationships of cooperation and reciprocity within their close social environment, the so-called "extended family". 
Although some of these cultural features have been gradually changing as Amazonian peoples become increasingly more integrated into national society and the economy, most Amazonians have not adapted to the ways of working or to the demands of industrial agriculture and large-scale cattle farming. The vast majority of failed "productive" projects in the Amazon are testament to this. Even if it were legally and commercially viable, investment in forest monoculture would therefore not provide jobs for Amazonian peoples, as some have tried to justify: these crops do not contribute to improving the lives of local people because they end up using imported labour (from the Andes or the coast) and promoting greater emigration into the forest

The problems caused by emigration into the Amazon are well-known: given the low profit margin on farming, many become involved in unlawful activities such as drug trafficking and illegal mining. The failure of the agribusiness development model in the forest has probably been partly responsible for the proliferation of different unlawful activities such as drug trafficking, illegal mining and logging, all of which are causing more degradation of the forests and water bodies, and contributing to the impoverishment of communities that depend on their ecosystem goods and services.

\section{The failure of a development model and its consequences}

The key to failed development in the Peruvian Amazon can be summarised thus: the promoters of this development focused their "attention on the land", promoting agribusiness alternatives when most of the Amazon's soils are poorly suited to agriculture and have other limitations (gradient, seasonal flooding, poor drainage). The real wealth, however, lies in the forest and its associated ecosystems (water bodies, Amazon wetlands) and in Amazonian cultures, which are more closely linked to forest, wildlife and aquatic resource management than agriculture.

Traditionally, the main source of the communities' livelihood, even those used for commercial purposes, has lain in the wildlife, forest and aquatic ecosystems (Pyhälä, 2003). Although clearly, some resources that are more appreciated by the communities (such as large animals and some species of fish) or those which have a market demand (especially valuable woods) have suffered serious extractive pressure, the Amazon still possesses enormous resources, many of which are either under-utilised or not used at all, and whose production potential for personal as well as market consumption is still largely undeveloped.

Road construction, undoubtedly an effective factor of development in connecting to the market and supplying services to rural populations, is becoming an enormous waste of resources in the Amazon (particularly in the lowland rainforest) and a serious threat, not only to the region's ecosystems and societies (whose vulnerability to extreme climate events has increased with deforestation and ecosystem degradation), but also to national security, given that without a sustainable production base the only things that occur are deforestation, trafficking in land, 
timber, wildlife and other resources, and illicit activities (illegal mining, drug trafficking and narcoterrorism). The lack of alternatives for the commercial exploitation of the standing forest's resources incites many Amazon dwellers, especially settlers, to cut down the forests and plant cash crops, despite their low profitability and high environmental impact.

\section{Deforestation and climate change}

The consequences of this one-sided vision of development in the Amazon have been tragic both for the local people and for the ecosystem. Settlement and the expansion of the agricultural frontier have resulted in the deforestation of some nine million hectares of forest. Saddest of all is that several million hectares have been felled in vain, as around $70 \%$ of that land has now been abandoned, and the remainder is of very low productivity (Dourojeanni, 1987; 1990; Brack, 2004).

Illegal gold mining has devastated thousands of hectares of forest, particularly in Madre de Dios, and has polluted the rivers of a number of Amazonian regions with mercury and other toxic substances, again, particularly in Madre de Dios. There are also other sources of this contamination: the chemicals used to grow and process coca leaf crops, opencast mining in the Andes, both in Peru and Ecuador, oil spills in the lowland rainforest... (Brack et al., 2011). Despite Peru's commitment to reduce deforestation to zero by 2020, some 50,000 hectares of primary forest continues to be lost every year, to which must be added an unknown number of hectares of secondary forest that have been felled again to establish crops or pasture (Figure 1).

Figure 1

\section{Deforestation in Peru 2001 - 2016}

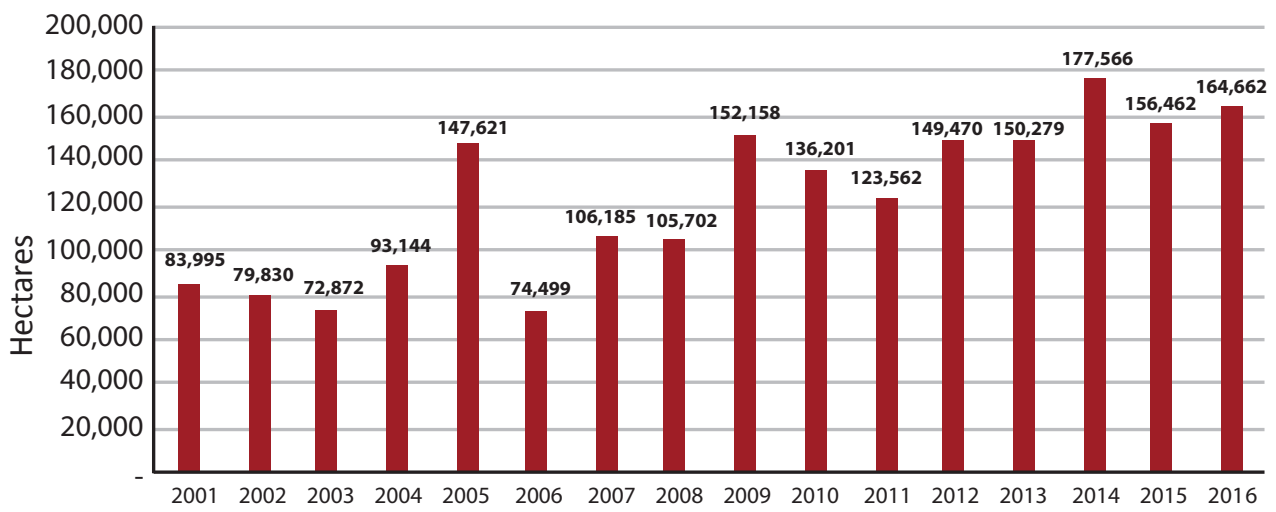

Source: National Forest Programme for Climate Change Mitigation - MINAM 2017 
The extreme (climate change-related) droughts that have blighted the Amazon over the last two decades (2005, 2010 and 2016) have not only encouraged extensive forest fires but have also caused serious damage to the forest canopy structure, killing numerous emerging trees and intensifying forest degradation. Experts anticipate that these droughts will become commonplace over the coming century.

The deforestation of the Amazon has not only resulted in serious erosion of the biological diversity; it is also affecting the regional climate, and contributing to global climate change. Some experts predict that the Amazon forest will have given way to savannah-type vegetation by the end of the century. A number of modelling studies indicate that the Amazon will have two critical points or thresholds: a $4^{\circ} \mathrm{C}$ increase in temperature, and deforestation of more than $40 \%$ of forest cover. If either of these thresholds is surpassed, this could result in a huge process of "savannisation", particularly in the seasonally dry areas to the south and east of the region. The Amazon has already warmed up by $1^{\circ} \mathrm{C}$, and deforestation has already reached 20\%. (Nepstad et al., 2008; Nobre et al., 2016).

\section{Map 1}

\section{Amazon Forest to 2030}

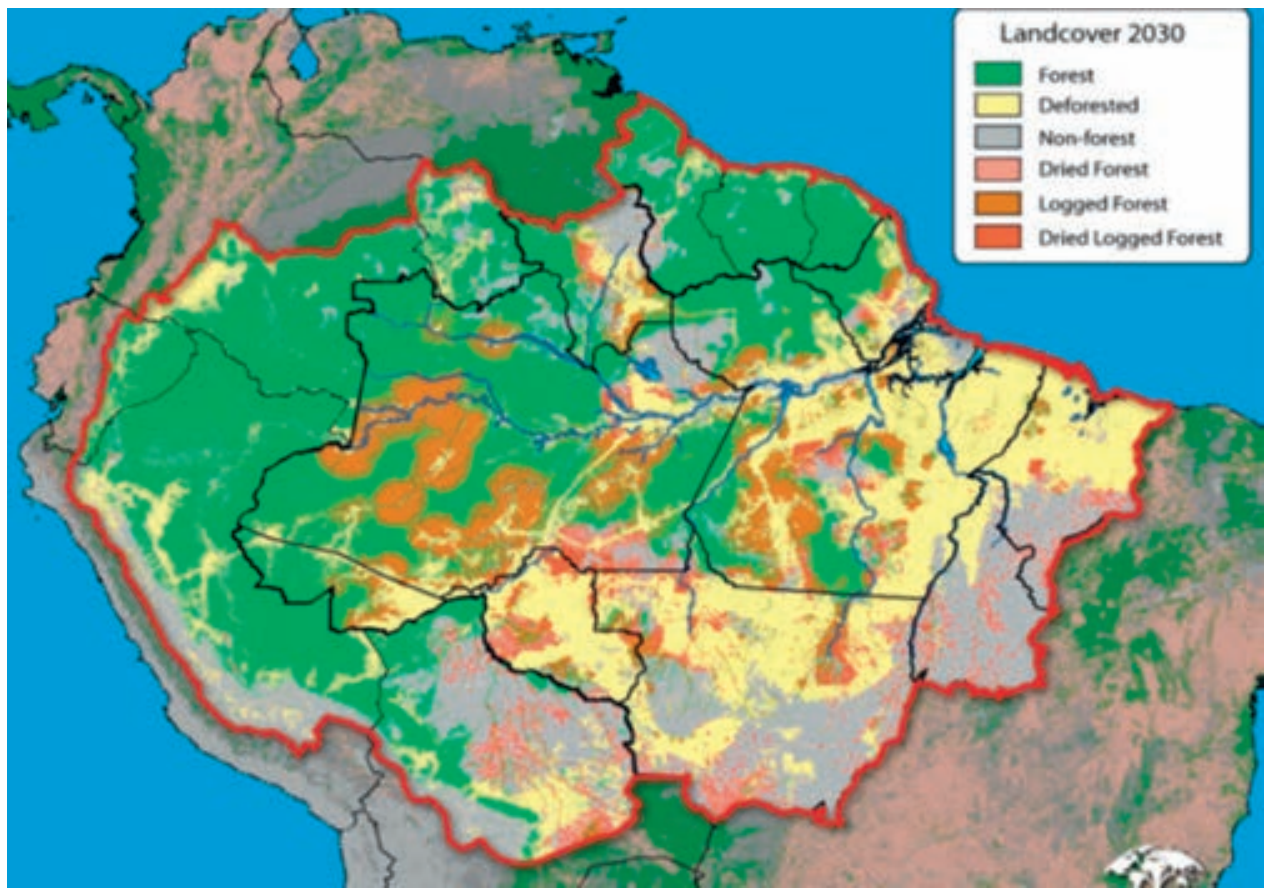

Source: Nepstad et al., 2008. The grey, yellow red and orange sections show areas damaged by drought, deforestation or logging, with 55\% of forests damaged by 2030 .

There is increasing evidence that the Amazon forest is acting as a regulator of regional and even hemispheric climate. In fact, in addition to absorbing solar 
energy and recycling rainwater through evapotranspiration (experts calculate that some $50 \%$ of rain is "convection" and produced through the condensation of water vapour evapotranspired by vegetation), it is now known that trees emit aromatic microparticles or aerosols that act as biogenic nuclei condensing the water vapour in the immense Amazon forest; an area where other condensation nuclei (generally dust microparticles) are very scarce. In other words, if we continue to fell the Amazon forest at the current rate, in coming decades there will be a dramatic decline in the region's rainfall (Cox et al., 2008).

\section{Degraded forests and aquatic ecosystems}

Deforestation is not the only problem for Amazonian forests: a series of extractivist waves (rubber, animal skins, timber, oil and gold) has resulted in the depredation and degradation of the ecosystems, as well as social degradation and misery for the Amazonian peoples whose economy depends on the health and productivity of those ecosystems.

To the amateur eye, and seen from a plane, most of the Peruvian lowland forest appears to be well preserved, with relatively limited areas of deforestation. However, a large proportion of the forests and associated water bodies is not healthy: the majority of areas that are most accessible from rivers and roads, and those closest to the population centres, have been exploited (logged for commercially valuable wood) and the large animal populations, most prized by game hunters, have been exterminated or reduced to very low levels (Peres \& Palacios, 2007). The situation is similar for the most valuable fish and other aquatic resources (García et al., 2008; Álvarez \& Shany, 2012). In addition, new remote detection technologies have demonstrated that selective felling, largely illegal, is not only degrading the forest but also significantly contributing (by more than $47 \%$ ) to the carbon emissions attributed to deforestation (Asner et al., 2010).

The degradation of the Amazon's ecosystems has serious ecological and socio-economic impacts. From an environmental point of view, the local extirpation of some species decreases the resilience and productivity of the ecosystems which, in some cases, stop functioning: for example, there is already evidence that excessive hunting of wild animals (many of which are agents of seed dispersal or vegetative control) is affecting the forest dynamic, changing the composition of species and causing erosion of the biodiversity (Terborgh et al., 2008).

The worst impacts, however, are socio-economic: the forests and their associated aquatic systems are the main sources of livelihood for local communities and their degradation has resulted in growing rates of chronic child malnutrition, pernicious anaemia and poverty. Chronic child malnutrition in indigenous communities in 2014 stood at $55.3 \%$ compared to $15.8 \%$ among the non-indigenous population (INEI, 2014). This situation is seriously jeopardising their development possibilities and pushing many young people to emigrate and / or become involved in unlawful activities. 


\section{So what can be done in the Amazon?}

If not agriculture (be it through introduced species such as oil palm or coffee, or native species such as cocoa, sacha inchi or palm heart) or cattle rearing, both of which have expanded hugely over the last two years with loans and deforestation, what can be promoted in the Amazon to generate income for the local population without alienating them from their culture and forms of social organisation, and without destroying or polluting the ecosystems that form the basis of their subsistence economy? The response is so obvious that it has perhaps been overlooked by the planners who have spent years promoting failed development projects: the forest and its associated aquatic ecosystems.

When we talk of the forest we are referring not only to its timber, which in Loreto and Ucayali is in serious trouble due to persistent illegality, with a number of markets now closed to the industry as a result. This industry has clearly not brought prosperity to those Amazonian communities involved in logging, as they have seen their territories degraded and have ended up poorer than they were to begin with, with no wood and no wild animals in their territories. Moreover, the medium-term prospects for the traditional forestry industry (large-scale, mechanised, focused on red and hard woods) are not very encouraging: there is increasing evidence that this model of forest exploitation is unsustainable as it would require cutting cycles much more frequent than at present, making the activity unprofitable $^{1}$ (Nasi \& Frost, 2009; Zimmerman \& Kormos, 2012; Richardson \& Peres, 2016). When we talk of the forest as a source of wealth, we are referring to the enormous variety of resources, particularly non-timber, that can be extracted from a standing forest and which have current or potential market demand (Dubois, 1996; Butler \& Laurance, 2009).

There are many voices calling for a new Amazonian development paradigm that would conserve the forests (incorporating advances in science and modern technology in order to develop products and services with high added value) beyond the current attempts to promote the creation of parks and reserves and to encourage agricultural intensification in areas already being cultivated, as a strategy to avoid extending the agricultural frontier (Nobre et al., 2015). This strategy of "agricultural intensification", which has already received enormous investment, has seen modest results in Peru and other countries, as demonstrated by persistently high rates of deforestation. Many people believed that if agriculture were made more profitable in areas already under cultivation it would help reduce deforestation but it has, instead, become a perverse incentive that has promoted yet more migration to the Amazon and an expansion of the agricultural frontier (Phelps et al., 2013; Carrasco et al., 2014).

1. Some intensively logged Amazonian trees can be of an astonishing age. A shihuahuaco (Dipteryx spp.) 1.20 metres in diameter at its base, for example, may be between 1,000 and 1,200 years old. The cutting cycles in concessions are every 20 years. (Chambers, J.Q., Higuchi, J.P. Schimel. 1998. Ancient trees en Amazonia. Nature 391:135-136.) 
The few development projects that have been successful within Amazonian communities are those that have sought to strengthen the communities' traditional methods of production and traditional organisation i.e. projects based on improving the management, processing and marketing of the natural forest resources: its flora, fauna and hydrobiology. However, very little has been invested in this regard, either by the State or by non-governmental organisations and international cooperation, and, as mentioned previously, this has focused primarily on supporting agriculture and cattle farming. Projects in the interior and the buffer zone of some protected natural areas supported by SERNANP (National Protected Natural Areas Service) and some cooperation organisations are the exception in this regard.

\section{Creating favourable conditions}

Promoting bio-business in Amazonian communities means creating favourable conditions to ensure that they are linked equitably, advantageously and competitively with ever more globalised markets. These conditions include formalising ownership of and access to forest resources, improving management and biodiversity product processing capacity, and improving organisational skills and links with the markets. Very little has been invested in creating what could be called "a productive Amazonian ecosystem".

One of the consequences of this lack of investment in forest resource management is rampant informality. Most community exploitation of forest and wildlife resources for commercial gain is currently informal. One reason is the complexity and high cost of formalising the process: a forest permit to exploit forest resources, either timber or non-timber (for example, wild palm fruits), can cost approximately USD 10,000 (Y. Guzmán, pers. comm.). There are very few communities that have current forest permits and, when they do, they have neither the capacity nor the tools to exploit them sustainably and profitably. Most communities with permits obtained them through an agreement with logging companies, who frequently buy their wood at derisory prices and leave the communities in debt to SUNAT (due to unpaid taxes) or with legal problems because they are using the permits to launder wood from other areas.

Another cause of this informality lies in the fact that most of the communities do not even hold the title deeds to their territories in order to negotiate a forest permit. It is currently very costly for an Amazonian community to obtain a property title: it can take several years and cost USD 15,000 or USD 20,000. The State has recently been promoting titling projects for some indigenous communities and considering proposals for simplifying the process. There are, however, no similar plans to formalise the territory of traditional resource use and exploitation for the ribereñas or mestizas communities, who make up the majority.

The problems of resource depredation, illegal felling, hunting and fishing, and ecosystem degradation are closely related to the bureaucratic barriers to formal- 
isation and the lack of investment in forest resource management, both on the part of the State and the cooperation organisations. To this must be added the lack of community capacity to integrate into the production chains and link to global markets as competitive businesspeople. The formalisation and operation of small community-based companies has come up against so many obstacles that very few continue to promote their business venture, or they fail after a very short time. This is a perfect scenario for producing the so-called "tragedy of the commons" (Hardin, 1968).

Different studies have shown that there is far less deforestation in titled territories or in those with clear access rights, than in freely accessible ones: for example, a recent study headed by the IADB showed that forest degradation is two-thirds less in territories managed by native communities than in State-owned areas (Blackman et al., 2017).

To these barriers must be added a lack of relevant knowledge of the forest and wildlife resource potential and of the opportunities existing in global markets, which are increasingly demanding natural products from ecosystems managed by communities through certified and fair value chains. The active ingredients in many Amazonian resources are still only partly known, if at all, and the same can be said for the technical aspects of their management or cultivation and processing, not to mention the market demand and business opportunities. Virtually nothing has been invested in Peru to close this knowledge gap.

All these obstacles have furthermore restricted private sector investment in value chains based on biodiversity resources. Very few companies have shown any interest to date in investing in bio-business development in the Peruvian Amazon, unlike in Brazil, where there has been investment; for example, the company Natura recently opened a cosmetics and nutraceuticals products factory using Amazonian resources in Belem do Pará, with investment of more than USD 300 million.

It should be noted that the market economy is rapidly making inroads into the Amazon region but local communities, particularly indigenous peoples, are being overlooked and ending up as poorly paid manual labourers for foreign investors, particularly in the areas of illegal logging, oil or mining companies. Many young people are emigrating to the cities in search of a better life, where they end up swelling the ranks of the unemployed or occupying poorly paid positions (motorbike taxi drivers, street hawkers, domestic workers, etc.).

Although the "company" is an institution foreign to Amazonian culture, some successful experiences show that indigenous and ribereña populations can also be productively involved in business, particularly in bio-business, in ways that are compatible with their culture and traditional forms of organisation and production, with the aim particularly of managing and processing forest plant and wildlife resources, as noted above.

In recent years, an unusual interest has emerged among indigenous communities and organisations with regard to bio-business as a development alternative that is more in line with their world vision and "life plans". For example, the 
Inter-ethnic Association for the Development of the Peruvian Amazon (AIDESEP) has created an Indigenous Economic area, aimed primarily at bio-business, and an Indigenous Peoples' Chamber of Commerce has also recently been created in Peru, grouping together around 20 community ventures that are striving to get ahead with businesses based on biodiversity resources.

\section{Biodiversity as a basis for Amazonian development}

Despite the depredation suffered by Amazonian ecosystems over the last century, they are still home to many biodiversity resources that not only have the capacity to contribute to food security but also to market potential, both internal and external. This could be managed and marketed with added value thereby contributing to substantially improving the economy of Amazonian communities. For example, with proper management, fishery resources and many species of wildlife could be recovered within a reasonable period of time. A number of Amazonian palm fruits that grow in abundance are known for their extraordinary nutritional, nutraceutical, medicinal and cosmetic properties, and products could be produced that are of growing demand among consumers; some have already been introduced successfully onto the international market.

To cite the example of wild palm: while people continue to fell trees to grow an introduced species that has serious socio-environmental limitations, there is an enormous variety of fruits produced by different palm species and other unexploited trees that could very easily meet market demands for food and natural cosmetics, while also providing sustainable and culturally-relevant sources of work and income to thousands of Amazonian communities. The abundant wild palms of the Peruvian Amazon include, in particular, the aguaje palm (Mauritia flexuosa), with between 6 and 7 million hectares of dense coverage in Peru. Others whose fruits are already used in Amazonian countries to produce different food and cosmetic products, include the huasaí (Euterpe precatoria), the ungurahui (Oenocarpus bataua), the huicungo (Astrocaryum murumuru), the puma yarina (or Amazonian oil palm; Elaeis oleifera), and the shapajas and sebones (Attalea spp.): in all no less than three to four million trees the fruits of which are currently unused in the forest.

A number of Brazilian companies have been able to benefit from the growing consumer interest in natural products and move billions of dollars per year into bio-businesses based on Amazonian resources, particularly the so-called "superfruits", such as acerola, guaraná, acaí, copoasú, Brazil, cashew and babassú nut; some are now even becoming commodities. The aforementioned company Natura, a specialist in natural cosmetics, many of them Amazonian, has flooded the Brazilian market and that of many other countries with its products.

Very few Amazonian products are marketed outside the Amazonian region of Peru, and then only on a very small scale. Some recent experiences show that it is possible for Amazonian communities to be profitably and sustainably involved 
in bio-business. One example is the Support Programme for Regional Conservation Areas in Loreto (PROCREL, now DICREL), which has managed to help dozens of families to escape poverty by exporting handicrafts made using "chambira" (Astrocaryum chambira) palm leaves to markets in the capital and the US (Álvarez \& Shany, 2012). Another example of success is the community management of hydrobiological resources in the Pacaya Samiria National Reserve, including paiche (Arapaima gigas), arowana fingerlings (Osteoglossum bicirrhosum), and broods of river turtle (Podocnemis unifilis), among other things.

The case of the Yellow-spotted river turtle is emblematic: from being on the verge of extinction, turtle populations have recovered so much - thanks largely to local community management - that, in 2016, 575,228 hatchlings were released and another 614,717 sold legally. In addition, more than a million "unviable" eggs were consumed in the communities or sold locally (MINAM, 2017). This is an extraordinary example of how to increase the value of a natural resource so that it benefits local communities and contributes effectively to its recovery and conservation.

Other similar projects have had recent success, such as the project promoted by PROFONAMPE (Fund for the Promotion of Peru's Protected Natural Areas) in Datem del Marañón (Pastaza - Morona Project) with various Awajún and Kichwa communities who are harvesting and processing wild palm fruit (particularly aguaje, Mauritia flexuosa, and ungurahui, Oenocarpus bataua) and with the Candoshi people, who have created a highly interesting production chain, based on the management and marketing of the fishery resources of Lake Rimachi (Musa Karusha). Various management groups in these communities are marketing products that add value to these resources. One community in the Upper Marañon (Chapís, of the Awajún people) has a small processing plant and is exporting aguaje and ungurahui oil to Europe (Y. Guzmán, pers. comm.).

There is a multitude of forest and aquatic resources that communities could sustainably exploit if there were sufficient investment in the various stages of the production chain, thereby creating food security and family incomes; many of these communities could find markets in developed countries, benefiting from current market trends.

In addition, the enhancement of biodiversity resources would significantly contribute to the conservation of Amazonian ecosystems. Pilot projects in recent years (particularly in Loreto, with the "productive conservation" strategy) have demonstrated that ecosystems are much better preserved when the communities are benefiting economically from plant and wildlife resources (Álvarez \& Shany, 2012).

There are studies that show that the exploitation of standing forest is profitable, even more than any other kind of legal use, if combined with environmental service payments (particularly carbon capture) and the sustainable management of non-timber forest resources (Figure 2). 
Figure 2

Net value of various forms of land use in tropical forests

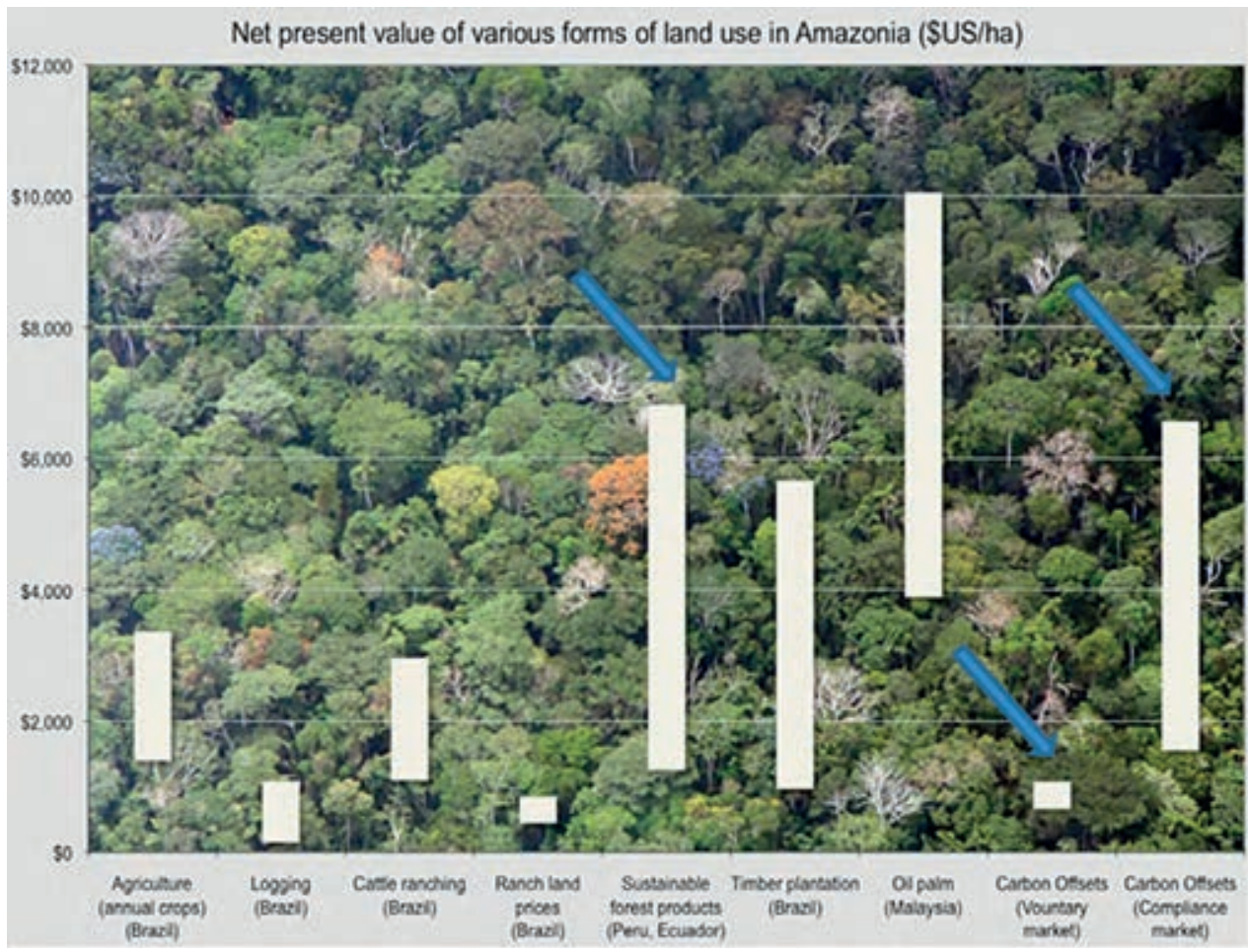

Source: Butler \& Laurance, 2009

Butler \& Laurance's study only includes current experiences of bio-businesses, which are very limited. If money were invested in enhancing the value of other resources, such as the palm fruits mentioned above, the profitability per hectare would increase significantly.

As regards the food security of Amazonian populations, there have been highly successful experiences with communities that have managed to recover their fishery and wildlife resources, and, consequently, to improve their diet and nutritional indicators. These have occurred primarily around protected areas, where there has been a specific concern for the recovery and conservation of natural ecosystems. One example is that of the Tamshiyacu - Tahuayo Regional Conservation Area in Loreto, where organised communities have been managing key resources according to their own internal rules for years, controlling access to illegal extractors, establishing harvest quotas for scarce resources and avoiding destructive practices (Figure 3). As a result, fishery and wildlife resources that are extremely scarce in other areas have recovered significantly, as in the case of the fishery resources of the Yanayacu basin (Regional Conservation Area of the Tamshiyacu and Tahuayo Rivers - ACRTT) (Figure 4). 
Figure 3

Reduction of destructive fishing activities in the ACRTT

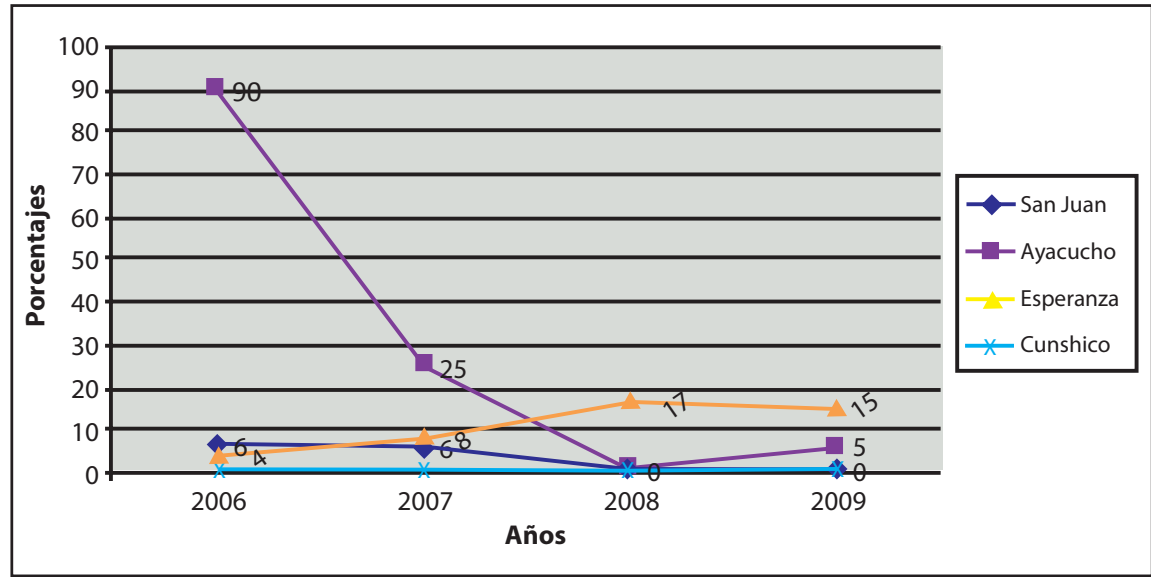

Source: PROCREL 2011

Figure 4

Capture per unit of fishing effort in the Yanayacu basin - ACRTT

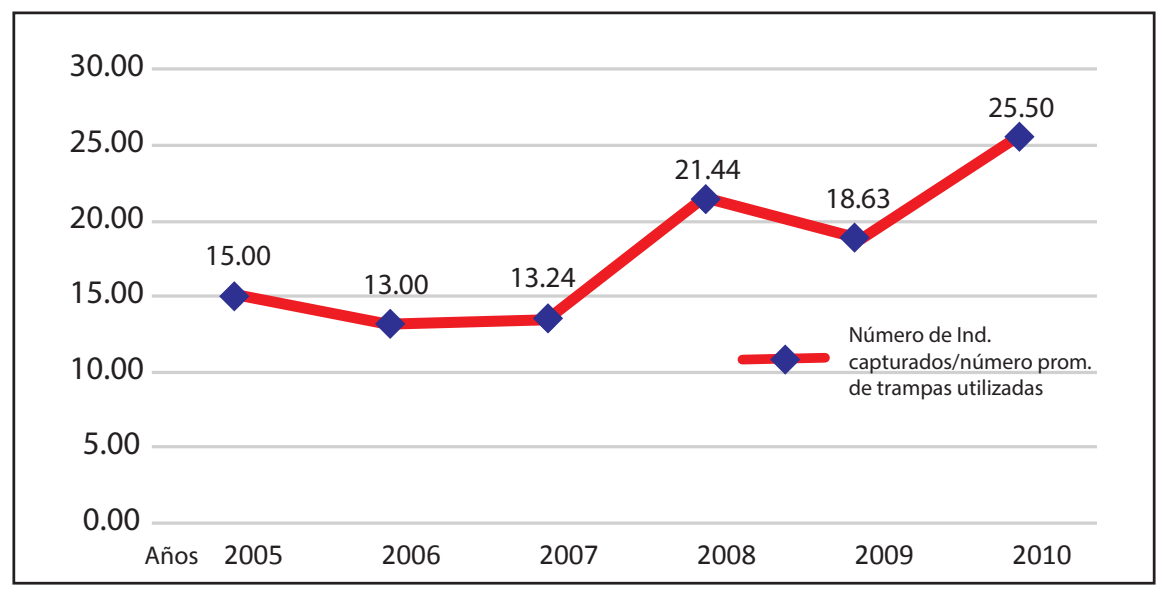

Source: PROCREL 2011

Chronic child malnutrition and pernicious anaemia have declined significantly in the communities living in the buffer zone of the ACRTT. This is most likely due to the recovery of fishery and wildlife resources as well as to improvements in family incomes due to the bio-businesses that many families are involved in. In comparison, the rest of the region and the Amazon generally, particularly indigenous communities, have seen these rates remain virtually static in recent years despite all the efforts and enormous State investment through different social programmes (Figures 5 and 6). 
Figure 5

\section{Anaemia and chronic malnutrition among children in the ACRTT}

Graph 6: Anaemia in under 12s, 2011-2014.

Esperanza Health Post, ACRTT. ACR Comunal Tamshiyacu Tahuayo.

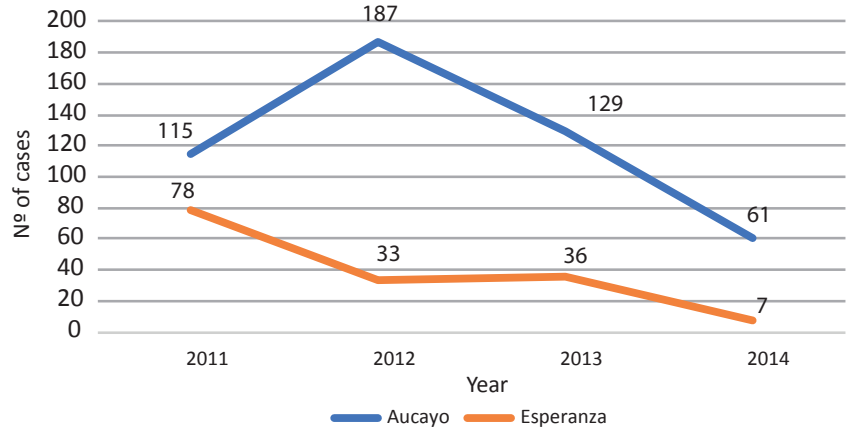

Graph 7: Malnutrition in under 12s, 2012-2014. Esperanza Health Post, ACRTT. ACR Comunal Tamshiyacu Tahuayo.

Source: DIGESA (General Directorate of Environmental Health of Loreto Peruvian Ministry of Health) 2015; PROCREL (Programme of Conservation, Management and the Biological Diversity in the Peruvian Department of Loreto) 2015.

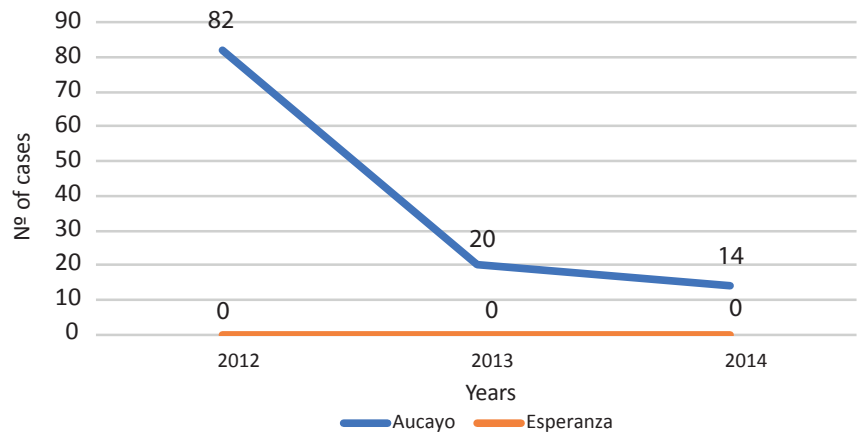

Figure 6

\section{Trend in chronic child malnutrition in Loreto}

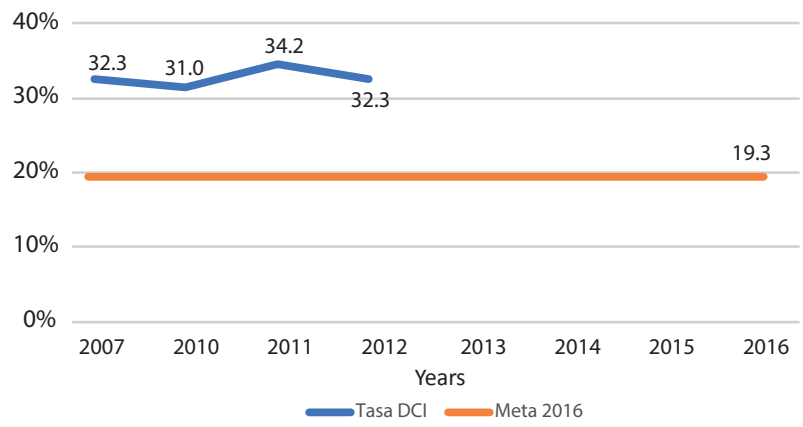

Source: MIDIS 2016. http://www.midis.gob.pe/images/direcciones/dgpye/reporte_loreto.pdf 
In terms of timber resources, given that the global markets for tropical hard woods will probably gradually dry up (as has been noted, their exploitation is scarcely sustainable), the best opportunities will be in community forest management, particularly fast-growing trees which prefer to grow in seasonal floodplain forest (tahuampas) along the banks of the Amazon's rivers. The Loreto and Ucayali regions are developing a proposal to facilitate the community management of five fast-growing species: cumala (Virola pavonis, V. spp.), bolaina (Guazuma crinita), capirona (Calycophyllum spruceanum), marupá (Simarouba amara) and carahuasca (Guateria elata). These species have very short cutting cycles (between seven to 15 years) and at least four of them regrow once the tree has been cut, which aids and vastly speeds up forest replacement and management.

Hard woods with added value offer another window of opportunity, particularly in terms of the production of useful objects (trays, bowls, and plates), toys, jewellery and other wooden pieces, etc. Some Amazonian communities are already producing hard wood handicrafts from a dozen or so species that have excellent graining and textures. Most significant of all is the fact that these handicrafts can be made using the thousands of trees that fall in the forest or that are submerged in the rivers and streams, given that the heartwood or hard core (known locally as shungo) can remain intact for many years and even acquire attractive hues when it has been submerged for some time. With the production and sale of these kinds of handicraft, a family can obtain sufficient income to cover their outgoings for a year or more from just one trunk.

\section{Proposal}

The proposal is to enhance the value of promising resources from Amazonian biodiversity in order to improve local food security, mitigate chronic child malnutrition and combat poverty. This will be done by creating the conditions in which to develop environmentally-sustainable and culturally-relevant bio-businesses that can reduce vulnerability to climate change and contribute to the productive conservation of Amazonian forests, thereby creating resilience to the extreme conditions that result from climate change. This approach would contribute to strengthening an integrated human development focus based around a community's own territory in terms of "expanding the opportunities for people to lead the life they cherish" (UNDP, 1990).

This effort requires many allies: the State needs to be involved, as does the private sector and international cooperation, because substantial resources are needed to create the conditions that will enable and strengthen the capacity to sustainably develop production chains based on innovative products, largely wildlife-based. Significant investment is also required to promote the appropriate management of natural ecosystems (forests and associated aquatic ecosystems are currently subject to severe, largely unsustainable, and, in many cases, illegal ex- 
tractivist pressure) and the social ecosystem (communities in extreme poverty and with serious limitations in terms of connecting competitively to global markets). Interventions aimed at recovering key resources in over-exploited ecosystems, particularly fishery resources, populations of aquatic turtles and wildlife in general are needed if we are to contribute to the food security of local communities.

It is up to the State to establish simple, formal and cheap mechanisms for accessing the biodiversity resources that are aligned with the environmental and social reality of the Amazon, including the formalisation of property, business and access rights to the resources (particularly local community lands but also via the different operating licences envisaged in the current Forestry Law and its regulations, as concessions for managing non-timber forestry resources, local forests and more). The same goes for management plans; these are essential for any commercial exploitation of a natural resource, according to the law.

The challenges:

- To productively conserve the forests and associated aquatic ecosystems, meeting Peru's commitments and creating resilience to climate change, while at the same time generating resources and incomes to combat poverty and chronic malnutrition among Amazonian communities.

- To enhance the value of biodiversity resources to the benefit of the population; this includes public and private financing to promote the recovery and management of the ecosystems and their resources, and to strengthen value chains, focusing on exploitation of standing forest.

- To bring biodiversity resource management approaches and models into line with the reality in Peru, and particularly that of the local Amazonian populations, by promoting:

- The formalisation of property and business rights among the Amazonian communities, and strengthening their capacity to integrate productively, fairly and advantageously into global markets.

- Administrative simplification to facilitate communities' formal access to forest resources.

- Participation in decision-making and resource management; and

- Fair and equitable distribution of the benefits resulting from biodiversity resource exploitation.

The conditions that will enable sustainable production chains to be promoted with communities in the area of bio-business include but are not limited to the following:

a) Territorial security for communities, which will enable them to manage the resources and to exclude outsiders and unsustainable uses; this can include both titled territories, where appropriate, and different methods of conserving spaces that enable the direct use of the resources (such as communal reserves, regional conservation areas, national reserves, conservation concessions, etc.) and 
management methods (forest concessions, particularly for non-timber forest resources, local forests, etc.).

Both territorial titling processes and the formalisation of other methods of conservation or resource management are costly and take a great deal of time. Substantial resources are required but these processes also need to be simplified and made less expensive.

b) Formalisation of management activities: this includes the formal setup of management groups and forestry (or hydrobiological resource) licences. The requirements for obtaining the approval of management plans are currently costly, complex, and take a great deal of time and resources, which is why very few communities or community members operate formally. These requirements need to be simplified for the communities and brought into line with their capacities via an adaptive and culturally-relevant approach.

c) Training and equipment for management, control and surveillance: to ensure the sustainability of resource exploitation (forest and hydrobiological), communities require capacity building (organising and training of management groups), both for resource management, and for control and surveillance, in order to dissuade outsiders and to put a stop to unsustainable extraction activities. Equipment includes communication and surveillance equipment (radios, torches), logistical equipment (boats and engines for patrolling, etc.) and the necessary equipment for managing and harvesting (for example, palm fruit harvesting requires putting a stop to the practice of felling palm trees to harvest fruit, and providing the management groups with equipment to climb the trees as well as training on its use). This task is very important in terms of improving food security because it enables the recovery and sustainable exploitation of key resources for communities, such as fishery and wildlife resources.

d) Initial processing and coordination with markets: adding local value, when possible, helps to improve the profitability of management activities and creates greater incentives to conserve forest. Market coordination under equal and fair conditions, in accordance with national and international regulations, is essential to guarantee the traceability and entry into niche market opportunities. Both issues require substantial investment and support for communities in the medium-term as a minimum.

e) Facilitation of formal business rights: it is excessively costly to formally establish rural community microbusinesses or producer associations, and there is a series of difficult or impossible bureaucratic hurdles to overcome. In practice, many remote Amazonian communities are unable to access the Registro Único de Contribuyentes (RUC or Single Taxpayers Registry) and cannot record the authority of the community's legal representative in public registries because the requirements are designed for city dwellers (water or electricity statements; deadlines that communities without good transport routes are unable to meet, etc.). It is essential to bring the regulations into line with the reality of communities and to promote 
training for their organisations, businesses and economic activities, which will clearly create conditions far more favourable to a more equitable and fairer integration with the markets.

Such an initiative, driven significantly by the State's different investment programmes and projects, with cooperation support and in alliance with the private sector (which will help promote environmentally, socially and economically sustainable production chains based on biodiversity resources, closing the gaps and bottlenecks mentioned previously), could change the history of the Peruvian Amazon. This is a region that is currently lagging behind national development, with stagnating and falling social indicators as well as scourges such as illegal mining, drug trafficking, unlawful felling and the loss and degradation of forests, but with the potential to become a hub of sustainable development and a net provider of ecosystem services for the world (carbon capture, hydraulic and climate regulation among others).

\section{BIBLIOGRAPHY}

ÁLVAREZ, A., Shany, J. \& N. (2012). Una experiencia de gestión participativa de la biodiversidad con comunidades amazónicas. Rev. Perú. Biol. 19(2): 223 - 232.

ASNER, G.P., Powell, G.V.N., Mascaro, J., Knapp, D.E., Clark, J.K., Jacobson, J., Kennedy-Bowdoin, T., Balaji, A., Paez-Acosta, G., Victoria, E., Secada, L., Valqui, M. \& Hughes, F.R. (2010). High-resolution carbon stocks and emissions in the Amazon. Proceedings of the National Academy of Sciences USA 107: 16738-16742. - doi: 10.1073/ pnas.1004875107.

BLACKMAN, A., Corral, L., Santos Lima, E. \& Asner, G.P. (2017). Titling indigenous communities protects forests in the Peruvian Amazon. PNAS vol. 114 no. 16 4123-4128, doi: 10.1073 / pnas.1603290114.

BRACK EGG, A. (2004). Biodiversidad, pobreza y bionegocios. UNDP. Lima.

BRACK, A., Ipenza, C. Álvarez, J. y Sotero, V. (2011). Minería aurífera en Madre de Dios y contaminación con mercurio. Una bomba de tiempo. Ministry of the Environment, Lima, April 2011.

BUTLER, R.A. \& Laurance, W.F. (2009). Is oil palm the next emerging threat to the Amazon? Tropical Conservation Science. Vol. 2 (1):1-10.

CARRASCO, R.L., Larrosa, C. Milner-Gulland, E.J. \& Edwards, D.P. (2014). A double-edged sword for tropical forests. Science. 346, 38. DOI: 10.1126/ science.1256685.

COX, P.M., Harris, P.P., Huntingford, C., Betts, R.A., Collins, M., Jones, C.D., Jupp, T.E., Marengo, J.A., Nobre, C.A. (2008). Increasing risk of Amazonian drought due to decreasing aerosol pollution. Nature. 8; 453 (7192): 212-5. doi: 10.1038/nature06960.

DOUROJEANNI, M. (1987). Aprovechamiento del barbecho forestal en áreas de agricultura migratoria en la Amazonía peruana. Rev. Forestal del Perú. 14(2):15-61.80 Bosques y pueblos indígenas frente al cambio climático y la globalización (1990) Amazonía, qué hacer. CETA. Iquitos. 
DUBOIS, J.C.L.(1996). Uses of wood and non-wood forest products by amazon forest dwellers. Unasylva - No. 186 - Forest-dependent people. Vol. 47 - 1996/3.

GARCÍA, A., Tello, S., Vargas, G. \& Duponchelle, F. (2008). Patterns of commercial fish landings in the Loreto region (Peruvian Amazon) between 1984 and 2006. Fish Fisiol. Biochem. Vol. 35, 1: 53-67.

GASCHÉ, J. y Vela, N. (2012). Sociedad Bosquesina, Tomo I. Instituto de Investigaciones de la Amazonía Peruana- IIAP, Iquitos. 292 pp.

GRANDIN, G. (2010). Fordlandia: The Rise and Fall of Henry Ford's Forgotten Jungle City. Metropolican Books, N. Y.

HARDIN, G. (1968). The Tragedy of the Commons. Science. 162: 1243-1248.

INSTITUTO NACIONAL DE ESTADÍSTICA E INFORMÁTICA (INEI). (2014). Family Demographic and Health Survey-ENDES, (2014). Cited by MIDIS (2016), Estrategia de Acción Social con Sostenibilidad.

MCINTYRE, L. (1980). Jari: A Billion Dollar Gamble. National Geographic. Vol. 157 no. 5. pp. 686-711.

MINAM. (2017). Dictamen de extracción no prejudicial de taricaya (Podocnemis unifilis) en la Reserva Nacional Pacaya - Samiria. Informe para emisión del permiso de comercialización de crías de taricaya.

NASI, R. \& Frost, P.G.H. (2009). Sustainable forest management in the tropics: Is everything in order but the patient still dying? Ecology and Society. 14: 40.

NEPSTAD, D.C., Stickler, C.M., Soares-Filho, B. \& Merry, F. (2008). Interactions among Amazon land use, forests and climate: prospects for a near-term forest tipping point. Phil. Trans. R. Soc. Bull. doi:10.1098/ rstb.2007.0036. Published online: http:/ / www.csr.ufmg.br/ britaldo/Nepstad_etal_08_PTRS.pdf.

NOBRE, C.A., Sampaio, G., Borma, L.S., Castilla-Rubio, J.C., Silva, J.S. \& Cardoso, M. (2016) Land-use and climate change risks in the Amazon and the need of a novel sustainable development paradigm. PNAS 113 no. 39, 10759-10768, doi: 10.1073/pnas.1605516113.

OSTROM, E. (2001). Reformulating the commons. En Burger, J., Ostrom, E., Norgaard, R. , Policansky, D. and Goldstein, B. (eds.). Protecting the commons: a framework for resource management in the Americas. Washington, D. C., Island Press, pp. 17-41.

OSTROM, E. (2009). Beyond Markets and States: Polycentric Governance of Complex Economic Systems. Nobel Prize Lecture on 8 December 2009 at Aula Magna, Stockholm University.

PERES, C.A., and Palacios, E. (2007). Basin-wide effects of game harvest on vertebrate population densities in Amazonian forests: implications for animal-mediated seed dispersal. Biotropica. 39:304-315.

PHILLIPS, O. et al. (2009). Drought Sensitivity of the Amazon Rainforest. Science. 323, 1344. DOI: $10.1126 /$ science. 1164033.

PNUD. (1990) Informe sobre el desarrollo humano (1990). UNDP. Tercer Mundo Editores, Bogotá. PROCREL. (2011). Informe técnico de monitoreo participativo en la zona de amortiguamiento del Área de Conservación Regional Comunal Tamshiyacu-Tahuayo. Informe Técnico Programa de Conservación, Gestión y Uso Sostenible de la Biodiversidad en la Región Loreto - PROCREL. Iquitos.

PROCREL. (2015). Informe Técnico del Programa de Conservación, Gestión y Uso Sostenible de la Biodiversidad en la Región Loreto - PROCREL. Iquitos. 
PYHÄLÄ, A. (2003). Productive Conservation in Amazonia: Institutions, Participation and Markets. PhD thesis submitted to the School of Development Studies, University of East Anglia, U.K.

RICHARDSON, V.A. \& Peres, C.A. (2016). Temporal decay in timber species composition and value in Amazonian logging concessions. PLOS ONE, July 2016 DOI: 10.1371/journal. pone.0159035.

SASSAN, S. et al. (2013). Persistent effects of a severe drought on Amazonian forest canopy. www.pnas.org/cgi/doi/10.1073/pnas.1204651110.

TERBORGH, J., Nuñez-Iturri, G., Pitman, N.C.A., Cornejo Valverde, F.H., Álvarez, P., Swamy, V., Pringlle, E.G. and Timothy Paine, C.E. (2008). Tree recruitment in an empty forest. Ecology, 89(6): 1757-1768.

TRAPNELL, L. (1982). El Tambo: por el camino del despojo y la destrucción. Amazonía Indígena. 4: 22-29.

ZIMMERMAN, B.L. \& Kormos, C.F. (2012). Prospects for Sustainable Logging in Tropical Forests. BioScience 62 (5): 479-487. DOI: https:/ / doi.org/10.1525/ bio.2012.62.5.9. 


\title{
AUTONOMOUS TERRITORIAL GOVERNMENT OF THE WAMPIS NATION
}

\author{
RECOVERING SOCIO-HISTORICAL AUTONOMY, BUILDING A COMMON \\ FUTURE
}

Shapiom Noningo

\section{Background}

The process of defending the territorial and other rights of the Wampis Nation is not a new one. During the colonial era, and even as far back as the time of the Incas, many Wampis leaders undertook heroic actions to defend their territory. By way of illustration, the actions of the leaders and warriors Sharian, Tsamarain and Kirup against rubber tappers and leather extractors are noteworthy, and against the soldiers who abused the Wampis people and their families, tarnishing their dignity and honour. They took the first actions of protest in order to defend the dignity and human rights of their families. The first local indigenous organisations emerged in the 1970s. One of these, the Aguaruna and Huambisa Council (CAH), in the northeast of Peru, took up their territorial claim in an organised and systematic way, taking advantage of Law Decree DL N 20653 issued at that time by the de facto President Juan Velasco Alvarado. This law meant that the process of registration, titling and expanding the Communal Territories could commence, and it was subsequently proposed that the State should create a Communal Reserve - under DL N 22175 - as the final stage of territorial consolidation. This was the Aguaruna and Huambisa Communal Reserve (1985). This was how the Wampis and Awajún communities attempted to achieve territoriality. Later, the concept of "territoriality" appeared for the first time, in a more legal and strategic way, in the book "The Indigenous Peoples and their Territory are One" (published by COICA and OXEAN America, 1991).

From that date on, local and regional organisations began to expand the titling process and made their demands for their ancestral territories known more loudly, demanding integral territories i.e. ownership by each peoples and not by community. Each region generally took this process forward in its own way. For example, CORPI SL (Regional Coordinator of Indigenous Peoples - San Lorenzo) and ORPIAN-P (Regional Organisation of the Indigenous Peoples of the Northern Amazon of Peru) followed the path of territorial recovery (territoriality).

As the final step in their socio-territorial demands, the Wampis Nation initiated a collective debate around the production of the Statutes of Autonomous Govern- 
ment in an initial meeting of the Wampis of the two basins, with the technical assistance of Dr. Pedro García ${ }^{1}$ who acted as the facilitator of the process. This process later continued in Kanus, where a first draft was completed and shared with the Kanus (Santiago River Basin) and, finally, in Kankaim (Morona River Basin), in the Alegría community (28-30 June 2015).

Through this historical process, the Wampis Nation agreed to create a government for all of the people (the Wampis Nation), higher than all of the communal, basin and organic levels hitherto established. They decided, by consensus, to establish an Autonomous Territorial Government (Provisional Government), with all the responsibility this entails. This historic event of great significance for the Wampis Nation took place on 29 November 2015.

In conclusion, it can be seen that the territorial claim process has not come about as an invention of politicians or academics, nor at the request of a specific leader, but is something that has only arisen in the last few years amongst indigenous peoples themselves. It has clearly not been at the direct or indirect suggestion of "external agents". This process is an historical, social, natural, genuine and legitimate process, free from outside ideologies. It is a process that has been taken up by members of the Wampis Nation to build their common future, a collective vision as a people, and to finally achieve Tarimat Pujut, "good living, a pleasant or full life".

\section{Formal beginnings of the Wampis Nation's autonomy}

This section expands on the above, given that the Wampis Nation decided to speed up this process of territorial recovery. They then, in coordination with CORPI SL, began preparing the technical (legal and anthropological) files, as set out in international treaties, that initiate the formal negotiations aimed at recognising their autonomy within the framework of self-determination as Original Peoples or Nations.

With their efforts redoubled from 2008 on, this process was positively received, obtaining financial support through international cooperation to help draft and finetune the technical files in support of integral territories for peoples such as the Candoshi, the Awajún, the Wampis and the Chapra.

The Wampis Nation commenced a discussion and process for drafting the Statutes of Autonomous Government in 2014, at an initial meeting of the Wampis of the two river basins. Dr. Pedro García acted as the facilitator in the Morona River Basin, and the text of the first draft was completed in the Kanus River Basin and shared with the Kanus once more. The Statutes were finally validated in an assem-

1. Pedro García Hierro (1946-2015), Spanish lawyer who took Peruvian nationality, arrived in Peru in 1971 to work in the Cenepa River Basin (Upper Marañón River) in support of the communities. His work, along with that of his co-workers, resulted in the creation of the Aguaruna Huambisa Council. He worked until his death supporting indigenous organisations in the Amazon and other parts of the world to claim their collective rights, especially to territory. 
bly held in the community of Nueva Alegría, in the Kankaim River Basin (28-30 June 2015). This same assembly also agreed to establish a commission to share the Statutes among all the Wampis communities of the Kanus and Kankaim River Basins. This commission comprised equal numbers of well-known individuals from each of the two river basins. Its hard work lasted for four months.

From July to November 2015, the commission visited almost all of the Wampis communities in the Kankaim and Kanus River Basins, holding assemblies in each of them. The agreements reached were set out in communal records. Each community that was visited approved the constitution of the Autonomous Territorial Government of the Wampis Nation and the integral management of the territory by acclamation. Finally, it was stated that they wished to maintain the socio-political unity of all members of the Wampis Nation.

In this historical process, the Wampis Nation agreed to take responsibility for the Autonomous Government of the Territory (GTANW) on 28 November 2015. The First Summit, held in the community of Soledad, in the Kanus River Basin, was undoubtedly an event of great historical significance in the struggle for their territorial claim, autonomy and self-determination as an original Amazonian people.

\section{Location and area}

The boundaries of the traditional Wampis territory are:

a) To the north, the border with Ecuador where our brothers the Shuar people live.

b) To the south, the mouth of the Santiago-Kanus River (where it meets the Marañón River), bordering the territories of the Awajún communities of Domingusa and Marañón, the town of Borja, the Awajún community of Ajachim, and as far as the hamlet of Colpa Unidos in the Lower Morona.

c) To the west, the Awajún communities of the Cenepa River, in whose headwaters the Wampis communities of Putuim and Wichim are located, and the Cóndor Mountain Range on the border with Ecuador.

d) To the east, the Morona-Kankaim River Basin until it meets the territories of the Chapra and Achuar peoples and Riverine villages (there are records of adjoining areas).

According to the occupation and traditional use that has been maintained to date by those who live here, the area of the entire territory of the Wampis Nation or Iña Wampistí Nunke comprises 1,327,770 hectares, of which 448,627 hectares are now officially demarcated (this figure includes titled land and those ceded in use). A further 879,143 hectares are still pending titling. The map of the Integral Territory of the Wampis Nation, the toponymy and cartography, form part of the Statutes, in accordance with Article 14(1) of ILO Convention 169 (Legislative Resolution 26253) and Articles 25 and 26(3) of the UN Declaration on the Rights of Indigenous Peoples. 


\section{The original reasons for and the final goal of the GTANW}

The self-recognition and self-affirmation of our territories (titled and ancestral) is based on our continued socio-historical and cultural existence. This relates to recognising the existence of indigenous peoples as original peoples prior to the formation of the nation-state, in this case the Republic of Peru. Its self-proclamation states that the Wampis Nation exists in and of itself, permanently, regardless of the will of the Peruvian State. This does not imply any renunciation of Peruvian nationality. On the contrary, it reinforces the people as one of the member nations of Peru.

The second aspect of this proclamation relates to self-recognition of the Wampis traditional territory, Iña Wampistí Nunke, defined as "the area between the Kanus (Santiago) and Kankaim (Morona) River Basins and the headwaters of the Cenepa River" ${ }^{2}$ This territory includes both titled lands and other areas not yet titled to the communities, but which, "are owned by the Wampis Nation by right of occupation and traditional and ancestral use, in accordance with international treaties and international jurisprudence". This territorial definition includes the area of the Kampankis Mountain Range and its eastern and western foothills, declared by the State in January 1999 as a reserved area. Kampankis, which does not yet have a final classification, sits at the heart of the traditional Wampis territory and links the Kanus and Kankaim River Basins.

The third aspect of this proclamation relates to the "commitments and responsibilities that are incumbent upon the present generation of Wampis in relation to future generations", which are enshrined in the formation of the Autonomous Territorial Government and the actions of all members of the Wampis Nation. Among these commitments and responsibilities is a clear requirement "to govern the territory in the general interest, to protect it from external aggression, maintain a healthy environment, claim collective rights when required, and define the structures of government, participation and external representation in accordance with the right to autonomy and customary law of the Wampis Nation."

As a political actor with deep historical roots, the Wampis Nation proclaims its continuity and demands its right to a self-recognised territory, as well as the right to exercise autonomous government over said space. The Wampis Nation has established its Autonomous Territorial Government and submitted files with additional studies to support its right to territory. In this sense, the Wampis seek to ensure the continuity of the biophysical and socio-cultural existence of their people: their language, culture and identity. This assurance is based on ownership of the lands, territories and nature generally, which are key elements. At the same time, they seek to control the serious impacts of commercial and economic activities, the policies and methods of which are typical of the neoliberal capitalist

2. This and the other quotes have been taken from the Statutes of the Wampis Nation Autonomous Territorial Government. 
system, which is massively affecting the welfare of humanity with serious negative consequences for nature.

Faced with this situation, the Wampis Nation has concluded that it is essential to exercise the special rights enshrined in the various national and international legal instruments immediately, demanding fair and necessary compliance with democratic norms. Under this principle and approach, the Wampis Nation will strengthen its system of social management, demanding that public institutions and the State comply with the aforementioned legal standards.

Another important reason is the desire to implement real and genuine territorial governance, i.e. to exercise effective and urgent management of the internal socio-cultural, economic and educational affairs of the Wampis Nation and, alongside this, to manage its external affairs, building a positive relationship with the State and the different levels of government. In conclusion, for the Wampis, governance means taking responsibility for collective and effective control of both internal and external aspects, a common vision and autonomous development, based on the participatory self-diagnosis of the people. In other words, it means building an instrument for the social management and guidance of internal issues and issues with the State (Strategic Plan), from which a contribution will be demanded from the State for large-scale social, economic and cultural demands, etc.

\section{Overall goal of the GTANW}

The goal is to achieve Tarimat Pujut ("good living, pleasant living, a full life").

Among the benefits of the GTANW are the following:

- It ensures the continuity of culture and of the biophysical existence of the Wampis Nation.

- It enables the management and achievement of Tarimat Pujut, a model for management and self-development.

- It provides the ability to independently drive forward the collective destiny of the Wampis Nation.

- It provides effective and guaranteed contributions to the global problem of climate change.

- It works as a ballast for the effective solution of socio-environmental conflicts.

- It involves the collective and participatory construction of a common destiny and for the development and achievement of Tarimat Pujut.

- It offers the possibility of participating in the country's regional and national issues, in areas such as climate change, democracy, good governance, public policies and hunger (Agenda 2030 Sustainable Development Goals / SDGs), and provides the collective capacity to do so.

- It establishes the Wampis Nation as an important political actor in matters of political participation and other aspects. 


\section{Intercultural interaction with the Peruvian State and its services}

Proper administration involves a positive, creative, proactive and future relationship with the State and its different levels of government: the Wampis Nation, proactive, demanding and democratic citizens, committed to the effective implementation of laws favourable to citizenship generally, and particularly to indigenous peoples.

Some key elements of the GTANW Statutes:

a) Territorial integrity. This refers primarily to two aspects:

- The whole of the historically-managed habitat (Article 23: Unity and integrity of the Wampis territory).

- The integrity of different spaces: cosmic space, land and water (Art. 21: Cultural definition).

- The unity and indivisibility of the territory is expressly recognised in Article 27 of the GTANW Statutes.

b) Natural Resources and the subsoil. According to the Statutes, subsoil extractive industries are not a priority for the Wampis Nation's development (Article 32, second paragraph).

c) Autonomy. This refers to decision-making capacity with regard to achieving Tarimat Pujut. This is a capacity that has been lost since coming into contact with Western society and which has been exacerbated under the Republic.

\section{Territorial hegemony, experiences and lessons learned from the past year}

- Homogeneous territory. Our starting point is the reality that our territory is not homogeneous because there are at least two mestizo settlements and even military bases within it. These do not form obstacles to the construction and consolidation of the Wampis' territorial autonomy and governance, however. Our plan is to build an area of peace and harmony in which to coexist, which is why we are creating positive and de facto relationship protocols. We are currently engaging in dialogue with this aim.

- Regarding our experience over the last year, some progress can be noted: internal sharing and dissemination within the communities is relevant and essential. We ourselves need to understand and own our Statutes before we can obtain State recognition. We must exercise our territorial rights and autonomy.

- Some lessons learned. Not everything is rosy. Not all Wampis think and act the same. There are critical, doubtful, distrustful groups, even detractors, but this is all part of the learning and growing process, with the aim of promoting our autonomy more enthusiastically and more resoundingly every day. 
- Initiatives of other Amazonian indigenous peoples in Peru to date: Achuar, Candoshi and Shawi.

- Initiatives of indigenous peoples from other countries and continents: cases of Bolivia, Ecuador, Panama, Greenland and Norway.

\section{Challenges}

The most important challenge to strengthening and consolidating the GTANW is that of ensuring the proper management of internal affairs. It is about building our own capacities (family, communal and organisational) through the creative empowerment of the GTANW process in order to achieve our final goal: "Tarimat Pujut". A second but no less important challenge is that of building creative and positive relationships between the Wampis Nation and the State and civil society more generally. These are two very complex but necessary and unavoidable processes.

\section{Summary of the GTANW Statutes}

The Statutes of the Autonomous Territorial Government of the Wampis Nation comprise eight headings and 94 articles, plus four transitory provisions. The following gives a very brief overview of their content.

\section{Self-determination and autonomy}

The first 11 articles refer to the context of self-determination within which the Wampis Nation and the Autonomous Territorial Government have been established, in the political and legal sense of the autonomy process, and in the context of international treaties. They deal with designation, identity, language, links to territory, future vision, culture, education, health care and food security, as well as setting out the basis for intercultural dialogue and designating the temporary seat of the Autonomous Territorial Government.

Article 10 expressly states: "The men and women of the Wampis Nation are also Peruvian citizens and enjoy all the rights and duties of other citizens on an equal footing. Respect for the Peruvian State and its representatives and a mutual relationship with our authorities are recognised as the basis for a peaceful and productive coexistence with Peruvian society. The Constitution of Peru and the international human rights treaties that supplement it form a framework which, together with these Statutes, are recognised and respected by our people".

\section{Rights and duties}

Articles 12 to 17 set out the rights of the Wampis Nation, communities and people. The collective rights of members of the Wampis Nation are framed within the international agreements, commitments and human rights treaties agreed or rat- 
ified by Peru. These include the right to self-determination, by which they freely determine their political state; the right to claim their identity and to belong to an indigenous people; to autonomy and self-government within their territories; to preserve, reinforce and control their own political, legal, economic, social and cultural institutions; to have a language of their own that is officially recognised and respected; to have a territory that guarantees the rights resulting from its traditional occupation; to determine, together with the State, their territory and to rely on effective measures to resolve their territorial claims; the right to reparation and / or restitution of lands and resources that have been confiscated, occupied, used or damaged without their prior, informed and free consent; the right to establish their own development priorities; the right to participate in public affairs and in any initiative that may affect them, including the benefits of any activity that takes place on their territories; and the right to free, prior and informed consultation and, where appropriate, consent to any State initiative that may directly affect their rights. The Autonomous Territorial Government of the Wampis Nation is the representative organisation called to accept, promote, organise and direct, together with the relevant Peruvian State authorities, all consultation processes related to the exploitation of subsoil resources or projects which, given their magnitude or impact, could affect the integral territory of the people.

The right to coordinated and systematic action from the Peruvian State to ensure the effective implementation of their rights is also demanded, along with: the right to establish programmes and technical bodies according to the autonomous government's needs and to run their own educational institutions and to jointly administer the health services with the Peruvian State; the right to have the Peruvian State take the necessary action to facilitate cross-border indigenous peoples' contact with other members of their own people or with peoples or nations related to the Wampis Nation, including activities of a spiritual, cultural, political, economic and social nature; the right to approach international bodies as a people or nation, for the protection of their rights; the right to technical and financial cooperation for the implementation of their collective rights; and that the Peruvian State should contribute the resources for the autonomous initiatives of the Wampis Nation in the cases provided by law and treaties, among others. These rights of the Wampis Nation are also the rights of the communities and all their members.

With reference to the communities, they have the right to be included in the integral territory of the Wampis Nation on an equal footing with other communities and to exercise and implement the autonomy recognised by the Political Constitution of Peru (administrative, economic, territorial and occupational, jurisdictional and governmental) in all internal affairs, provided that their decisions do not fall within the powers of supra-communal bodies in accordance with the Statutes themselves. With these limitations, the Statutes recognise the right of communities to elect their authorities, issue rules, make use of their resources and decide the internal system of land distribution, resolve conflicts, participate in the election, 
control and monitoring of the Autonomous Territorial Government, receive support and benefit fairly from any advantages coming from collective initiatives and projects approved in line with the Statutes.

The Statutes also specify the rights of individual members of the Wampis Nation, and protect Wampis women, girls, boys and youths, encouraging their involvement in collective and governance issues. The Statutes encourage the involvement of women and young people in public affairs and governance bodies, setting aside a number of positions of direct representation for them in these areas.

Article 18 highlights that it is the Autonomous Territorial Government's duty to guarantee the exercise of these rights.

Articles 19 and 20 specify the duties falling to the communities and the women and men of the Wampis Nation.

\section{Territory and territorial organisation}

Articles 21 to 27 refer to the territory of the Wampis Nation, Iña Wampistí Nunke. They focus on a cultural definition of the territory, and affirm its unity and integrity as a necessary condition for guaranteeing "good living". This is to include decent subsistence and appropriate development, autonomy and self-determination, as well as the food sovereignty and security of Wampis families. This should be done by encouraging social, economic, political and cultural relationships that guarantee the protection and appropriate management of nature and the environment.

They also set out the commitments and responsibilities that fall to each generation of Wampis for future generations in terms of protecting their territorial legacy, a central aspect of the existence of the Wampis as a nation, and their collective rights.

These articles also note the duties and guarantees that the Peruvian State must provide to the territory of the Wampis Nation, including the inviolability of territorial ownership. For its part, Article 27 states that the Wampis Nation: "respects the unity and indivisibility of the Peruvian State and respects and defends the integrity of the territory of Peru and the provisions set out in international agreements and treaties ratified by Peru".

Articles 28 to 31 refer to the territorial organisation of the Wampis Nation, based around the existence of basins, sub-basins and communities. They also refer to territorial planning on the basis of a cultural vision that will provide a future management plan for the territory's resources, and how this will need to be respected when planning the territory's management and deciding the economic activities to be undertaken by exploiting the territory's resources. They further indicate that the territory of the Wampis Nation will maintain mutually cooperative relationships with the district and provincial authorities within its jurisdiction, respecting their authority. This will involve close coordination with the municipal structures to ensure social and economic development, and participation in the planning, management, budgeting, evaluation and monitoring of public expenditure. 


\section{Governance: external and internal dimensions}

Articles 32 to 39 develop the external dimension of territorial governance, establishing consultation as a key instrument in the exercise of autonomy and governance. They also explicitly refer to areas under special regimes that have been established by the Peruvian State, declaring that there is no waiver of pre-existing rights, and noting the necessary coordination with the Peruvian State to develop a management plan that allows the recovery, modernisation, systematisation and definition of a traditional management model for the hills on either side of the mountain range. They also declare the Kampankis and Kampankisa Murari hills as spiritual centres of the Wampis territory and part of their own cultural and spiritual heritage where the vital processes that allow for the reproduction of the territory's biodiversity are developed.

Articles 40 to 45 develop the internal dimension of territorial governance. For this, the uses of the territory, skills, ways of protecting communal forests, basin headwaters and water resources are all laid out. With regard to the Awajún communities located on the Wampis territory, the Statutes state that they will be respected, endeavouring to maintain relationships of harmonious coexistence, friendship and good neighbourliness.

\section{Self-government and structure of the Autonomous Territorial Government}

The principles of self-government are also defined: the indivisibility of the institutional representation of the Wampis Nation, democracy, gender equality, ethical transparency and accountability, culture, holistic vision and conservation, collective well-being, justice, interculturality, self-determination and the recovery of knowledge and ancestral wisdom in the search for well-being.

Articles 47 to 49 define the structure of the Autonomous Territorial Government, making Uun Iruntramu the Supreme Governing Body, comprising representatives from the member communities in the form of the Irunin elected in their respective assemblies. In turn, the Central Executive Government is the body responsible for the government and administration of the Autonomous Territorial Government, with the Pamuk as head and the Pamuka Ayatke as vice president.

Governments are also established for each basin, the highest authority of each being the assembly or Matsatkamu Iruntramu. The Council of Elders is also established as an ad hoc body of the Autonomous Territorial Government, made up of recognised and notable people known for their experience, moral strength and vision as advisors. In the communal sphere, the highest authority is the assembly, formed of competent community members as recorded on a Register, with a Governing Board being the body responsible for government and administration. Articles 50 to 72 of the Statutes list the powers and functions of these governing bodies; they also define sole, shared and parallel responsibilities. 


\section{Internal Justice and Social Control}

Articles 73 and 74 refer to the validity of the customary norms of social control and the system of sanctions in the communal, basin and central bodies.

\section{Electoral system and election of authorities}

Articles 75 to 80 establish the formation of Usuikartin for the election of the Autonomous Territorial Government's authorities and with responsibility for issuing records. They also set out the ways in which organised participation will be decided in elections for the municipal, regional and national authorities. 



\title{
DEFORESTATION IN TITLED NATIVE COMMUNITIES 2000-2015: THE CASES OF THE INDIGENOUS AWAJÚN PEOPLES OF ALTO MAYO AND THE KAKATAIBO PEOPLES OF THE CENTRAL FOREST
}

\author{
Sandra Ríos Cáceres, Ermeto Tuesta and Richard Chase Smith
}

The fact that Peru is one of the ten most megadiverse countries in the world is due primarily to the diversity of its Amazonian forests. These forests comprise a great wealth of tree species, along with thousands of other plant, insect, animal and fish species that also dwell there. This same forest has been inhabited for at least the last 10,000 years by indigenous populations who have learnt to live in harmony with the biodiversity, through ancestral practices that have become appropriate ways of managing natural landscapes and resources (Summers and Ríos, in Smith and Soria, 2017).

The threats to these Amazonian forests have been growing over the course of the last two centuries. Around the end of the $19^{\text {th }}$ century, tracks began to be constructed for mule transportation, such as the Pichis Way, which connected Lima to navigable Amazonian rivers and then on to Europe. In the $20^{\text {th }}$ century, during the 1920s-40s, the first roads for motorised vehicles established a basis from which, over the 1960-1990 period, the Marginal Highway (Carretera Marginal) and its branches would be consolidated. This infrastructure encouraged huge settlement programmes, with the overriding and clear objective to develop agricultural and, in some areas, fishery activities. Throughout the whole history of this "conquest", primary forests were lost at an ever increasing rate. (Smith and Ríos in RAISG, 2015).

The negative impact of this history of forest penetration on the biodiversity might not have been so serious if it had been managed from a different perspective; from that of clear policies and plans promoting sustainable usage, along with equitable economic growth for the region. The conquest was a chaotic one, however, with uncontrolled clearing of large areas of forest and pillaging of resources. For many who migrated to the Amazon in the hope of a better quality of life for their families, the colonial dream resulted in disillusion, unless they became involved in more profitable activities with criminal connotations. Large areas of forest are continuing to be destroyed and burned despite international commitments made by recent governments, such as "Zero Deforestation by 2021", a timeframe that has now been extended to 2030 .

Deforestation in the Peruvian Amazon is continuing rapidly. According to official figures, between 2000 and 2017 alone, 2,130,122 ha were deforested (MINAM, 2018). According to MINAM (2017), only 17\% of the deforestation occur- 
ring between 2000 and 2015 took place in titled native communities. These figures concur with those published by the Instituto del Bien Comun and the Red Amazónica de Información Socioambiental Georeferenciada regarding deforestation between 2000 and 2015 (RAISG, 2016).

The causes of deforestation differ in terms of their distribution and intensity throughout the whole of the Amazonian region and Peru (RAISG, 2015). While one of the main problems in the Madre de Dios region is illegal mining, in the case of Alto Mayo, in San Martín, it is the trafficking of land for agricultural activities that is the predominant issue; in the Codo de Pozuzo, in Huánuco, it is the invasion of cattle farmers in search of pastureland; and in Aguaytía, in Ucayali, it is invasions for increased farmland on which to grow agricultural and illegal crops. The list goes on and varies according to the different Peruvian Amazonian regions.

What is happening to the titled native communities in those areas being deforested? To answer this question, we will focus on the communities of two indigenous peoples: the Awajún of Alto Mayo and the Kakataibo of the Central Forest (Selva Central).

\section{Deforestation in the indigenous territories of the Awajún of Alto Mayo and the Kakataibo of the Central Forest}

The indigenous peoples of the Peruvian Amazon have suffered the relentless practice of the invasion of their lands and incessant deforestation of their forests. This history has forced them into a constant struggle to defend their territory and their fundamental rights.

As the pressures and threats have increased in number and variety, so the indigenous peoples have evolved. They have acquired spaces that have enabled them to recover part of their territories and to gain respect for their rights, making them ever more visible. For example, with the signing of ILO Convention 169, many communities began to raise the issues of territory, identity, language, culture and their own ways of relating to other indigenous peoples.

They have gradually taken ownership of legal and technical mechanisms, and this has led the indigenous movement to think about producing their own standards and norms, resulting in the need to come up with a plan for territorial management from an indigenous perspective. Such management will need to legally consolidate all forms of use, ownership and management of the territorial space of each indigenous community, as well as to enshrine self-determination, as noted in the UN Declaration on the Rights of Indigenous Peoples.

A large part of the Amazon region is currently involved in public and private sector initiatives which are developing and implementing projects aimed at generating profitable or alternative produce; however, they generally have no continuity, and do not receive any technical advice on how to manage them. The picture is not clear because, while some State sectors are promoting resource con- 
servation, others are encouraging their exploitation, indicating that the projects are in the national interest, by generating income for the State and for local populations. The State's initiatives on indigenous territories have generally failed and resulted in chaotic situations, however, with the result that large areas have been deforested and the local population have received only meagre incomes (Álvarez, in Chirif, 2018).

\section{The Awajún of Alto Mayo}

A group of Awajún people have been settled in the region of San Martín and the provinces of Rioja and Moyobamba for more than 100 years. Their communities have been titled since 1975, shortly after the enactment of the first Law on Native Communities in 1974 (Tuesta, 2018. Unpublished). Three decades ago, some of their leaders encouraged the processes of internally parcelling their territories: although the land remained communal, each plot holder would henceforth be able to negotiate the logging of their plot individually and, later, also the renting of their land to agricultural investors (Chirif, 2018).

It is essential to note the important role played in this process by the highway completed at the start of the 1980s and paved in the 2000s. It is today one of the three main arteries connecting the coast to the forest. This is the Marginal Highway, now known as the "Fernando Belaunde Terry" highway, forming the IIRSA Norte which connects the river port of Yurimaguas to the seaport of Paita, in Piura.

When the first Awajún native communities in Alto Mayo managed to secure their territories through collective property titles in the 1970s, some State institutions, together with some civil society organisations, began to promote agricultural activities within them. In the communities of Bajo Naranjillo and Shampuyacu, they encouraged deforestation in order to sow soya and, later, as this was not an ideal crop for this area, rice. The Awajún did not have a tradition or any knowledge of growing rice, however, and were not provided with any support, such as linking into nearby markets to sell their produce. From the 1980s on, migrants began to arrive in the area from Cajamarca (Chirif, 2018), and they asked the Awajún to rent them their land for a three-year period at a payment of 500 sols per hectare. This use of the communal territory, under norms established by each community, became a way of generating income that would cover the community members' health, education, food and travel costs (Tuesta, 2018. Unpublished).

These agreements with the settlers, which have since extended over several decades, have resulted in a major increase in the rate of deforestation in the communal areas of the 14 Awajún communities in this zone. This, in turn, has meant that, between 2000 and 2015, the Awajún experienced the highest level of deforestation within their titled native communities of all indigenous groups, with a total deforested area of 76,752 ha. The loss of forest cover in the 14 Awajún communities living in the Alto Mayo zone is 36,895 ha, i.e. $48 \%$ of the total area deforested by the 193 Awajún titled native communities in the country (See Map 1). 
Map 1

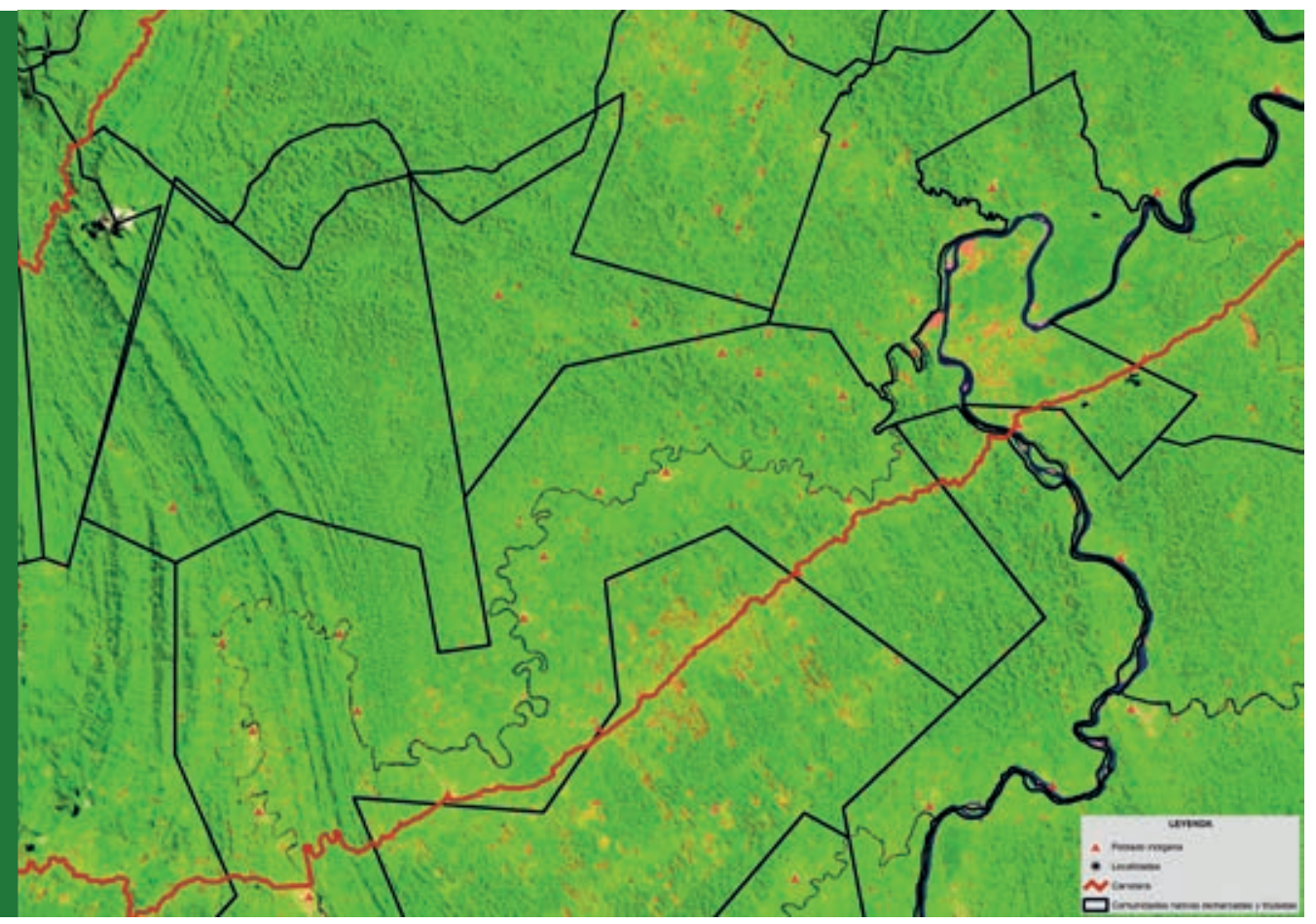

The titled Awajún communities of Alto Mayo with the greatest deforested area are Huascayacu, Shimpiyacu, Alto Mayo, Bajo Naranjillo, Shampuyacu and Morroyacu. According to data from the IBC (2014), the native community with the most deforestation between 2000 and 2010 was Huascayacu, registered in 1975 and titled in 1998 and which, over the period in question, suffered an average loss of 500 ha of forest cover per year.

\section{The Kakataibo of the Central Forest}

The communal territory of the Kakataibo indigenous people is crossed by the "Federico Basadre Highway", which connects Pucallpa to the mountains, the Central Forest and Lima. This highway makes the area easily accessible and thus a destination for settler migration which, along with other causes and factors, has resulted in the extensive deforestation of the zone (Ríos, 2014). It is an area subject to significant pressures and threats due to oil fields, mining concessions, forest concessions and plots of illegally-sown coca.

The main causes of deforestation within the Kakataibo native communities, as identified by the leaders themselves, are invasions onto their land and the trafficking of land for agriculture, cattle rearing and illegal crops (Ríos, 2014). The controversial renting of land by a certain group of community members against the wishes of own leaders is another cause of deforestation. At the same time, there has also been an interest on the part of other community members to replicate the State's and international 
organisations' illegal coca eradication and poverty reduction programmes through the promotion and granting of economic incentives to plant oil palm and fruit crops such as papaya or cocoa, or to develop cattle farming, etc. (Ríos, 2014.)

Some 10,306 ha were deforested in eight titled Kakataibo communities over the 2000-2015 period. The highest rate of deforestation was noted in the Puerto Nuevo community, located to the south of the Federico Basadre highway, in the districts of Codo del Pozuzo and Puerto Inca, the province of Puerto Inca, Huánuco, and in the Irazola district, Padre Abad province, Ucayali region.

Deforestation in the Puerto Nuevo community reached its highest figures in 2005 and 2016 (see Map 2). During these years, the Kakataibo's complaints of invasions of their territory increased considerably; unfortunately, the conflict led to violent clashes with the invaders, resulting in the deaths of community members, including a two-year-old boy. ${ }^{1}$

\section{Map 2}

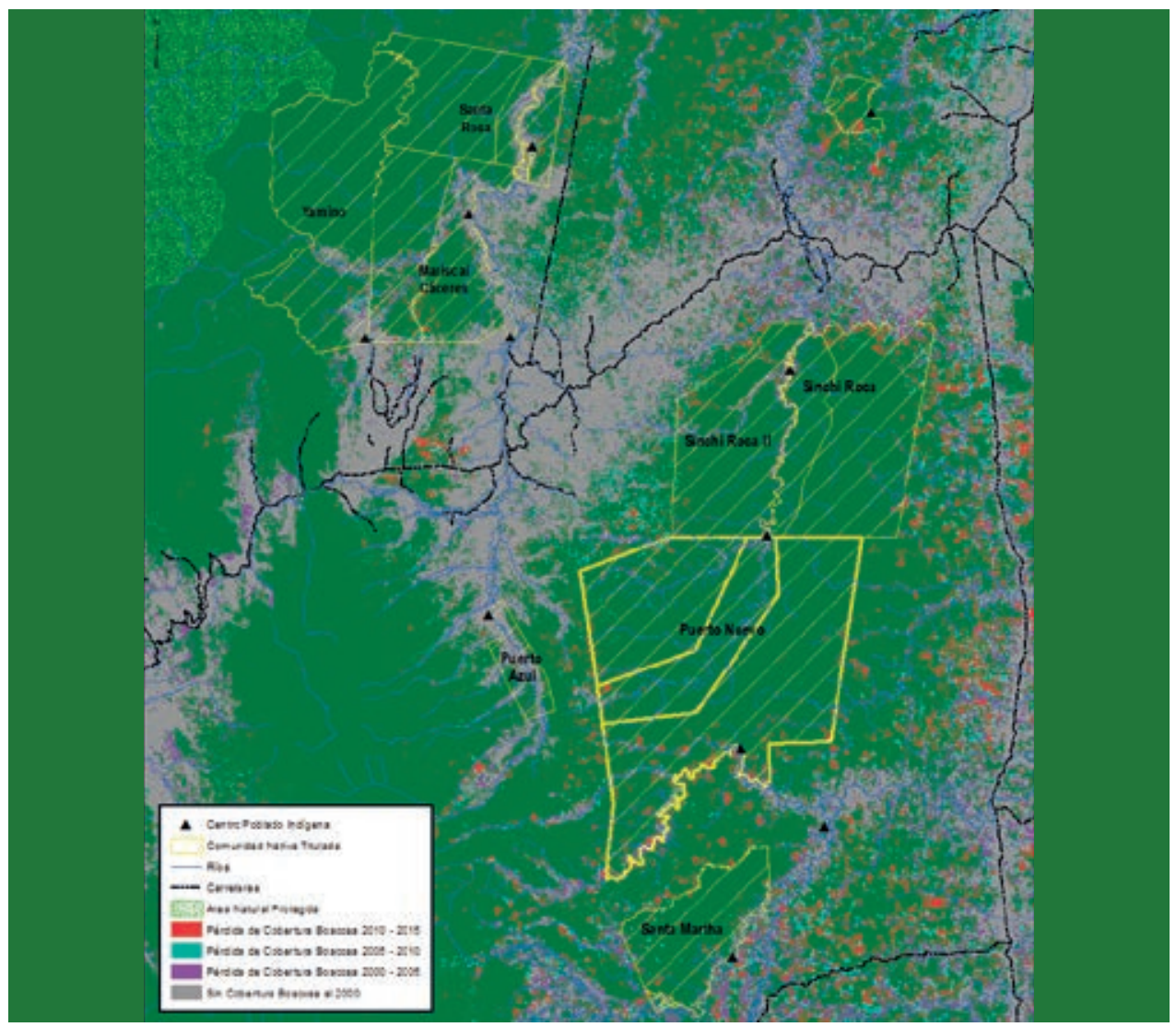

1. News on Servindi: https:/ / www.servindi.org/ actualidad / 49441: “Perú: Colonos invasores asesinan comunero Cacataibo por defender territorio comunal" 
Although the Kakataibo communities lost three times less forest area than the Awajún of Alto Mayo over the same period, the images demonstrate how deforestation outside of the communities had already begun to reach the boundaries of areas that only became titled in 2005. In contrast, in Alto Mayo, most of the communities' boundaries were already impacted by deforestation by the year 2000 .

\section{Similarities and differences between the pressures to deforest in the two cases}

In both cases studied, the start of the deforestation process was linked to the grand plans of successive governments, who had been promoting the "conquest" and incorporation of the Amazon into the national market since the end of the $19^{\text {th }}$ century. Behind this desire for invasion was always a development model based on deforestation and a change in land use, however poor these lands may have been. Until very recently, neither forest and biodiversity conservation nor environmental sustainability formed part of the development discourse. (Cabieses, in Chirif, 2018).

The fact that both the Peruvian State and society have, since colonial times, spread a rhetoric that considers the indigenous inhabitants of the Amazon to be barbaric avages who, as such, cannot be protected by the Constitution unless they are "civilised", also plays a part in forestry degradation. This concept has given rise to attitudes of permissiveness and laziness with regard to protecting indigenous peoples' territorial and civil rights, and has resulted in concrete and violent actions aimed at intimidating and persecuting indigenous leaders who oppose economic extractive activities on their territories.

The speed with which deforestation has been occurring since 2000 in the communal territories is alarming in both cases. This can be seen from Maps 1 and 2 , which give the area of "No Forest" in that year and the deforestation occurring since then and up to 2015. The same phenomenon can also be seen in information gathered during participatory workshops and interviews in the field (Tuesta, 2018. Unpublished), in which community members described how deforestation has taken place in their communities and what the main causes and factors of this are.

The deforestation figures for the titled Awajún communities of Alto Mayo are alarming and represent a loss of $28 \%$ of the forest that was remaining in 2000. Behind these figures is concealed the fact that two communities have suffered the most deforestation, however: the Huascayacu and Shimpiyacu, which have lost $78 \%$ and $43 \%$ of their 2000 forest mass respectively $(9,679$ ha and 16,030 ha between 2000 and 2015).

The deforested area as a proportion of the 2000 forest mass represents only $5 \%$ for the Kakataibo. The communities with the highest rates of deforestation among these indigenous people have lost on average of less than $7 \%$ of their forest area, with the exception of Puerto Azul, a community with a demarcated area of only 4,139 ha and which had a forest area in 2000 of 2,047 ha, of which $11 \%$ had been lost by 2015 . 
The high deforestation in some of the Awajún communities of Alto Mayo, unheard of in other areas where these people live, or in zones under significant pressure and threats such as those of the Kakataibo, raises a number of questions as to the causes and factors of deforestation.

It is clear that the main cause of the high deforestation rate in these communities has been the individual parcelling up of communal lands to enable the new "owners" to rent out their land to farmers and foreign investors with the aim of sowing cash crops. In the case of the Kakataibo, where there has been no experience of such a process to date, the direct causes of deforestation are different. The pressure to deforest does not lie in commercial farming but in the threat of settler invasions and land traffickers aimed at turning them over to subsistence farming, which goes hand in hand with illegal coca growing, the establishment of pasturelands and, in some areas, illegal mining. These last two activities have been reported largely in communities located to the south of the Federico Basadre highway, in the Huánuco region.

Despite communities in both areas facing massive external demand for lands, the histories and processes, factors and causes have been different in each case. Both cases began with the presence of national-level surfaced roads passing relatively close to the communities. On top of this, public policies were developed and implemented, aimed at encouraging productive activities without any proper planning or evaluation of the actual impact these would have on the local population and forest. The differences in the deforestation histories of the two cases can be explained by a series of factors, such as the extent of their historical/cultural roots in their own territory, the capacity and quality of community governance, the kind of social relations between the communities and settlers, land traffickers and investors, the direction of local and regional public policies and also physical and climatic factors.

\section{So what will happen to the more than 13 million hectares of forest in the titled native communities?}

Having lost large areas of forest without reducing poverty, which was after all the aim of the different development projects, there is now an expectation that this model should be redefined and redirected towards proper management. This should be done from the perspectives of the indigenous and other local populations who were living in harmony with the forest and its resources many years before the arrival of the dream of the colonisation and development of the Amazon.

The indigenous peoples of the Peruvian Amazon, who are suffering continued invasion and threats to their lands and a relentless degradation of their resources within and around their communities, are clear that the reaffirmation and recovery of a traditional management model must form part of the struggle to ensure a good quality of life for their members while, at the same time, providing the world with forests that offer protection from climate change. Their voices are 
now being heard in the different national and international spaces in which the Amazon's future as one of the lungs of the planet is being discussed and where the functions it has been fulfilling throughout history are finally being recognised.

There is an urgent need for the government and international organisations to add concrete actions to this effort, replicating the few successful development projects that have been implemented in Amazonian communities: those that sought to strengthen the communities' traditional methods of production and organisation.

Working models such as those being implemented in the Putumayo-Amazonas region for more than 20 years by the Instituto del Bien Común (IBC), and which have strengthened local communities and populations environmentally, promoting different forms and categories of conservation along with solid governance and institutions, should be included to support the indigenous peoples in their desire to conserve their territories and resources.

It will be important to strengthen initiatives such as the Ministry of the Environment's Forest Conservation Programme which are stimulating and recovering the value of the standing forest through payments for areas conserved within the titled native communities, along with the generation of activities that contribute to sustainable development. It should be noted that this initiative is now working in the titled communities of the Kakataibo people.

Moreover, according to members of the Alto Mayo titled community, they are now working on a project with Conservation International (CI) entitled "Zero Deforestation", which consists of reforesting the riverbanks, improving production, recovering the forest, establishing agroforestry systems, and reducing the use of pesticides, fertilisers and herbicides, as well as other initiatives. They are hereby improving the productivity of their lands in order to prevent further deforestation.

Preventing the repetition of the history of the native communities of Alto Mayo, avoiding the continuing loss of large areas of forest, and ensuring that the Kakataibo are redirected towards the conservation and good management of their territories is truly a task for everyone, from the highest level down to the most localised, and including State bodies, non-governmental organisations, academia, the private sector and the indigenous communities themselves. 


\section{BIBLIOGRAPHY}

ÁlVAREZ, J. (2018). Bosques y Pueblos Indígenas Frente al Cambio Climático y la Globalización. In Deforestación en tiempos de Cambio Climático. IWGIA. Lima.

CABIESES, H. (2018). Coca, Bosques y Pueblos Indígenas Amazónicos. In Deforestación en tiempos de Cambio Climático. IWGIA. Lima.

CHIRIF, A. (2018). Deforestación en tiempos de Cambio Climático. IWGIA. Lima.

IBC. Mapa de Amazonía peruana (2016). Deforestación 2001 - 2015. Lima.

MINAM. (2016). La Conservación de Bosques en el Perú (2000 - 2016). Lima.

MINAM. (2018). GeoBosques. Estadísticas oficiales in: http:/ / geobosques.minam.gob.pe/ geobosque/view/perdida.php. Lima.

RAISG. (2016). Mapa: Amazonía 2016. Áreas Protegidas y Territorios Indígenas. Deforestación 2000 - 2015. Sao Paulo.

RÍOS, S. (2014). Proceso de Deforestación en el Territorio Cacataibo 1995 - 2010. IBC. Lima.

SMITH and Ríos. (2015). Deforestación en la Amazonía peruana. In RAISG. Deforestación en la Amazonía (1970 - 2013). Sao Paulo.

SUMMERS and Ríos. (2017). Chapter 4. El Mundo de los bosques en la Amazonía peruana. In Smith and Soria. Atlas de Comunidades Nativas y Áreas Naturales Protegidas del Noroeste de la Amazonía peruana. IBC. Lima.

TUESTA, E. (2018). Documento de Trabajo: Entrevistas en campo a indígenas awajún en Alto Mayo. 



\title{
THE DEFAUNATION OF THE TROPICAL FORESTS AND ITS ENVIRONMENTAL IMPLICATIONS
}

\author{
Claudia María Gálvez Durand Besnard
}

\section{Summary}

The tropical forests are clearly acknowledged as holding a greater diversity of species than can be found in any other terrestrial ecosystem. They are also considered a key element in global climate balance, as well as a strategic reserve of genetic resources and freshwater. In recent years, however, there has been a drastic decline in the geographic distribution of many mammals, particularly in larger species, primarily due to human activity. This effect on the wildlife has consequences for the plant communities they interact with and, in turn, affects the quality of life of Amazonian peoples who depend on these resources for their existence.

The aim of this article is to draw attention to the ecological impacts and consequences for local livelihoods due to this decline in wildlife, caused by anthropic activities in the tropical forests. It highlights the importance of wildlife in maintaining forest health and identifies different forms of hunting and habitat loss as the main causes of this decline. It recommends taking wildlife into account in conservation strategies as long-term conservation of tropical forest vegetation will not be possible unless the fauna are also conserved. Likewise, a distinction must be made between monitoring deforestation and monitoring biological degradation; the latter will require long-term human and financial investment at a wide range of sites.

\section{Introduction}

The tropical forests are clearly recognised for holding a greater diversity of species than can be found in any other terrestrial ecosystem. Many tropical forests contain hundreds of tree species and some even more than 1,000 (Terborgh et al., 1992:1). These forests are considered a key element in global climate balance; globally they store $>460$ billion tonnes of carbon, more than half total atmospheric storage (Pan Y, et al., 2011), as well as forming a strategic reserve of genetic resources and freshwater (Álvarez \& Shany, 2012:223; Peres et al., 2016:1).

Given their importance as a habitat, tropical forests play a major role in the efforts to conserve biological diversity. And yet there is little understanding of the role of species interactions in stabilising the dynamic of the tropical forests and maintaining the flow of natural ecosystem services, including that of acting as a long-term carbon sink (Peres et al., 2016:1). Research into forest loss generally 
focuses on forest cover and assumes that the standing forest remains in good condition. Throughout the discussions, tall and majestic trees are taken as symbolic of the group of animal and plant species found in the tropical forests. The trees are also used by some conservation biologists, park planners and others as representing the whole biota of tropical forests, and as a measure of the conservation value (Redford, 1992:412), without realising that large animal species have very often been extirpated from these forests. While many ecologists have documented the important role played by large animals in seed dispersal, seed depredation, grazing, pollination and depredation, few have considered what would happen if these animals were removed from the system (Redford, 1992:15).

There has been a drastic decline in the geographic distribution of many mammals in recent years, particularly the larger species, and this is due primarily to human activities (Sánchez, 2002:3). This has had consequences for the plant communities with which these animals interact and, in turn, has affected the quality of life of Amazonian peoples who depend on these resources for their livelihoods (Álvarez \& Shany, 2012:223).

\section{Defaunation, empty and semi-empty forests}

Dirzo \& Miranda (1991:6) define defaunation as the loss of wildlife due to human causes, emphasising the need to maintain the fauna within an ecosystem in order to preserve not only its distinctive elements but also the ecological processes that maintain them.

Recognition of degraded areas, in which the diversity of flora and fauna has declined to varying degrees, has been established under the concepts of "empty forest" (Redford, 1992), in which mammals and birds have been totally eliminated and their ecological roles left vacant, emphasising the threat to biodiversity due to hunting in tropical forests (Wright 2003:74) and "half-empty forest" (Redford \& Feinsinger, 2001). These forests appear at first sight to be healthy ecosystems, as they retain large trees, small birds and reptiles; however, they may be heavily affected in terms of their fauna. Many of these forests are "living dead" and although they are registering as forests via satellite, they are empty of wildlife inside. An empty forest is a condemned forest (Redford, 1992:421; Álvarez \& Shany, 2012:224).

Given the important functional role that mammals play in their ecosystems, the defaunation of the forest not only negatively affects the diversity of mammal communities; their abrupt extirpation can also trigger trophic cascades, the downwards effects of which have the potential to affect the overall organisation of the ecosystem such that forest preservation will be impossible unless the fauna is also conserved (Redford, 1992:421; Terborgh, 1992:283).

Anthropogenic impacts on natural ecosystems are, moreover, usually assessed in terms of the vegetation (deforestation and fragmentation). Efforts have been made to quantify the area of relatively intact forests remaining throughout the 
world, usually by means of widely available images such as Landsat (Peres et al., 2006:1). Few studies have considered defaunation, partly because this variable cannot be picked up via remote sensors. There is, however, overwhelming evidence that it is in many cases, considerable and may, in turn, have significant consequences for the vegetation (Dirzo, 2011:1; Phillips, 1997:298).

\section{Causes of defaunation}

Very few areas of tropical forest retain pristine groups of mammals and birds. Surprisingly low densities of human population can devastate wildlife, either directly (through subsistence hunting, for example) or indirectly (through the elimination of foodstuffs critical to many species by cutting down fruit trees and destroying habitat) (Phillips, 1997: 294; Redford, 1992:412).

One of these indirect threats to the fauna of the Amazonian forest is deforestation due to mining or farming expansion, selective felling for timber and alluvial mining. Many of the products of modern life also contribute to contamination, such as the use of mercury, which affects fish.

Ramírez-Mejía \& Mendoza (2010:8) indicate that the main factors threatening forest wildlife are commercial hunting and habitat loss (through deforestation or alteration). Activities such as hunting and deforestation used to be heavily restricted in both time and geographic space. Areas would therefore usually have time to recolonise and felled forests would generally regenerate. Technological and demographic expansions however, have meant that these same activities are now becoming omnipresent, giving the tropical forests fewer opportunities for recovery (Phillips, 1997:291, Benítez-López et al., 2017:8; Núñez-Iturri et al., 2018:1536). By 2050 , with the planned increase in roads, human population and demand for wild meat, which is growing constantly, it is likely that the term "remote" will be a thing of the past, with the last remaining mammal and bird populations almost exhausted but surviving in protected areas. (Benítez-López et al., 2017:8).

Some specialists believe that alteration and destruction of natural habitats is currently having a greater impact on forest wildlife than different forms of hunting, with deforestation for agricultural purposes clearly affecting the largest areas of land and greatest diversity of species. (Peres \& Ojasti, 1996:75; FAO, 2016:4). Other studies instead suggest that hunting is more dangerous than forest fragmentation because, with the exception of some social mammals that live in large groups and require a wide-ranging territory (Tayassu pecari, Lagothrix spp., Cacajo spp.), most species of neotropical mammals are able to survive on fragments of $>1000$ ha provided there is a complete absence of hunting (Peres, 2001:1499; Harrison R., 2011:919). Moreover, hunting and fishing for family consumption removes potential prey, affecting predators, scavengers and the animals that depend on them (Redford, 1992:413). Hunters move from one place to another, leaving forest behind them that is empty of the characteristic species that play an important ecological 
role (Harrison R., 2011:919). The largest primates, such as Ateles and Lagothrix, as well as some large members of the cat family, caiman, raptors, macaws and game birds, have all been largely extirpated from the Amazon (Phillips, 1997:298).

In any case, human activities that generate disturbances in the tropical forests almost always occur at the same time, such that they have a synergistic effect (Peres, 2001:1491; Phillips, 1997:292). The effects of habitat loss and hunting are thus not independent of each other as the habitat destruction opens up new areas accessible to hunters and hunting has a greater impact on mammal populations that have been decimated by habitat loss (Peres, 2001:1496; Wright, 2003:74).

\section{Impact of deforestation}

When we talk of deforestation in the tropics, we tend to mean the conversion of a continuous forest landscape into patches of remnant forest scattered across a wider area of unforested vegetation (Turner, 1996:200). The spatial aspects of the fragmentation are typically visible and quantifiable on the basis of satellite images. However, the subsequent disintegration of the ecosystem into isolated fragments is largely invisible from the air, as these fragments can acquire a simpler biological status without evident changes in the structure of the vegetation or repopulation of the canopy (Phillips, 1997:294). The sensitivity of tropical forests to fragmentation is because deforestation reduces the area of available habitat for wildlife and creates strong barriers to their movement (Petren, 2001:301). Under equal conditions, the largest fragments will support more species than the smaller ones but even the largest existing forest reserves may be inadequate to protect all their species (Phillips, 1997:295). Their reduced size and increased isolation thus makes populations more susceptible to stochastic demographic and environmental events such as biological invasions of exotic species or species more typical of a successional habitat (Lande, 1988:1458; Phillips, 1997:303).

The effect of fragmentation is, however, different for each species and largely depends on the inhospitability of the kind of vegetation that invades areas cleared of their original habitat (Redford et al., 1995:12). As a forest becomes fragmented, the fauna loses those species whose spatial needs are not met (need for large areas of unaltered forest). This is often the case for large predators, large primates and large ungulates, generally under strong pressure from human activities. In some respects, fragmentation thus has a similar impact on wildlife to that of hunting (Kattan et al., 1994:139; Redford et al., 1995:12; Petren, 2001:301; Phillips, 1997:303).

Various studies have also demonstrated declines over time in the diversity of resident birds within a fragment or group of fragments of forest (Kattan et al., 1994:139). Not only are those species no longer available for direct exploitation by humans, but their absence changes the remaining species' community (Redford et al., 1995:12; Petren, 2001:301). However, while some species may be seriously affected, others - with greater environmental flexibility or those that use ecotones 
- are favoured by the proliferation and dissemination of ecotonal zones caused by fragmentation (Turner, 1996:202; Redford et al., 1995:12).

\section{Changing composition of forests through selective felling}

Faunal composition is also influenced by changes in the location of, and modifications to, forest vegetation. It is important to understand some of these potential influences in order to help predict fluctuations in wildlife populations (Redford et al., 1995:11). Selective timber extraction, eliminating fruit trees or those used for nesting, or affecting critical areas such as nesting sites along shores for migrating birds or turtles, may have adverse effects, particularly on wildlife species of economic interest to the human population. Forests thus altered do not guarantee the presence of resident fauna in them (Redford, 1992:412; Redford et al., 1995:12). Forests with declining large-seed tree species will offer fewer resources for large vertebrates. Even if hunting could be controlled, the recovery of the original community of trees would probably be delayed due to the reduced presence of large vertebrate populations (Terborgh et al., 2002:1767).

\section{Impact of hunting on wildlife}

A wide variety of forest animals are hunted by humans for food (Redford, 1992:413); mammals being the most sought after and eaten throughout the world, followed by birds, reptiles and amphibians (Redford, 1992:413; Redford et al., 1995:17; Nasi \& Van Vliet, 2011:362). The choices made by hunters and the ability of the selected species to withstand this exploitation will together determine which of these species is at greatest risk (Wright, 2003:75).

It is to be expected that the abundance and composition of mammals is different in areas where hunting does and does not take place. Among the most significant mammals that are hunted, there is a particular preference for larger sized animals: herbivores such as monkeys, wild pigs, peccaries, deer, armadillos, agouti, and capybara; among birds, the most commonly caught are turkey hens, curassow, toucans, trumpeters and macaws (Redford, 1992:414). As the pressure from hunting increases, there is a gradual but drastic reduction in the contribution of large species to the total biomass of primates, while the biomass of small and medium-sized animals instead increases (Peres \& Dolman, 2000:176; Benítez-López et al., 2017:7).

On the other hand, a high concentration of hunting does not always result in local extinction. The impact of hunting is different for different animals, resulting in the loss of more sensitive species (commonly the larger species requiring wider areas to maintain viable populations, and with low reproductive rates) but enabling the survival of more tolerant species (more resilient, of smaller size, with higher reproductive rates and able to live in more general habitats) that are capable of adapting to circumstances either by modifying their biological parameters or 
inhabiting niches left empty by more vulnerable species so that they continue to prosper in natural and amended habitats (Nasi \& Van Vliet, 2011:362).

Hunting is not only a subsistence or traditional occupation, as settled farmers also tend to hunt to supplement their income. Commercial hunting involves many species and can change according to supply and demand, with damaging consequences for local wildlife populations mainly because this kind of hunting can become unsustainable (Redford et al., 1995:28). The impact on fauna is greater depending on the proximity to and accessibility of the animals' habitats and urban markets, as well as the condition of the protected areas and the type of hunting (Benítez-López et al., 2017:6). Throughout the Amazon Basin, the abundance of animals largely depends on how accessible an area is to hunters rather than its protection status (Harrison R., 2011:919). The use of modern firearms and the capacity to export skins, live animals and smoked meat to numerous markets has resulted in the extinction of at least 80 animal species since the 1600s (WCMC, 1992, quoted in Wright, 2003:75).

In Peru, according to the former General Directorate for Forestry and Forest Wildlife (now the National Forestry and Forest Wildlife Service), approximately 13,033 live animals were seized between 2009 and 2012, and, in 2014 alone, this number totalled some 4,000 specimens. ${ }^{1}$ The wildlife supply chain includes various intermediaries, processors and transporters. Where a wildlife market is firmly established, production and sales therefore provide work and an income for a large group of people (Redford et al., 1995:28).

\section{Impacts of defaunation on the forest vegetation}

The relationship between the flora and fauna of a tropical forest is quite complex. Studies into the consequences of defaunation have systematically indicated that the ecology of forests that are subject to intensive hunting is seriously altered (Harrison R., 2011:919). Vertebrates consume nectar, pollen, flowers, fruits, seeds and leaves, and disperse pollen and seeds, kill seeds and plants and reduce areas of foliage (Wright, 2003:77). Changes in the distribution and abundance of animals affect fundamental ecological processes such as pollination, seed dispersal, recruitment, consumption of seeds and plants, as well as decomposition and the nutrient cycle, threatening the integrity of ecosystems the world over by interrupting plant-animal interactions (Catterall et al., 2003:1; Núñez-Iturri et al., 2008:1536). Although few studies relate the indirect effects of defaunation to the forest plant community, it is clear that this can cause a gradual change by simplifying the forest community. It should be noted that most plants have a longer life cycle than most animals, and so the effects of this decline on plants may not be immediately evident (Phillips, 1997:298).

1. National Strategy to reduce illegal trafficking of wildlife in Peru, 2017 - 2027, and its 2017 -2022 action plan. 
According to Catterall et al., (2003:1), there are three processes crucial to plant regeneration, and they are strongly influenced by interactions with animals. These are:

1. Pollination. Most plants in the tropical forest rely on animals (primarily insects but also birds and mammals) for pollination, with notable interdependencies between species.

2. Dispersal. Seed dispersal is an ecological process that influences plants in many ways. Most rainforest plants depend on animals (primarily birds and mammals) to disperse their seeds and some end up in places that are suitable for their germination and growth. The large animal species preferred by hunters are often the dispersers of the largest seeds in tropical forests; they are capable of swallowing the largest seeds and dispersing them over great distances (Phillips, 1997:298; Harrison R., 2011:921). When populations of various of these animal species decline and even disappear over a prolonged period of time, some plant species are simply not capable of regeneration (Phillips, 1997:298), particularly plants with large seeds (many slow-growing canopy trees), as opposed to plants with smaller seeds or which are abiotically dispersed (Harrison R., 2011:921; Núñez-Iturri et al., 2018:1541).

3. Recruitment. Seed predators; primarily mammals or insects such as beetles and moths, have significant influence over seed survival (adapted from Catterall et al., 2003:1). Predators such as jaguars and pumas regulate the population densities of medium-sized mammals, which in turn, limit seed recruitment. Changes in the composition of mammal communities may have major effects on the diversity of tree species (Asquith et al., 1997: 941).

The results of different research studies clearly indicate the potential that seed-eating mammals have in terms of the population dynamics of tropical forest vegetation, showing that the absence of just one species of herbivorous mammal can be sufficient to affect the composition of the undergrowth. It is clear that a significant decline in mammals will therefore alter the regeneration of seeds and break down the network of interspecific relations between flora and fauna (Asquith et al., 1997:945; Wright, 2003:83). The positive compensation here lies in the fact that the hunting of large primates will result in an increase in the number of smaller species at the sites they used to inhabit. It is unlikely, however, that these species would be a substitute for the reduced "wild animal value" of an overhunted forest or contribute with quantitatively similar or alternative ecosystem services, such as the dispersal of large-seed plants (Peres \& Dolman, 2000:187).

\section{Impact on human way of life}

Of the direct benefits to humankind, perhaps the most important contribution that wild animals make is as a source of food. Wildlife provides a significant proportion of the animal protein in rural diets in many developing countries around the world 
(Redford et al., 1995:4 and 28). In parallel with this, game meat forms an important source of income for hunters and for the intermediaries who broker its sale (Redford et al., 1995:28). The degradation of Amazonian ecosystems, particularly the decline of wild animals, therefore also has social consequences as it will result in increased malnutrition among the local populations who depend on them for a source of protein, thus diminishing their quality of life (Álvarez \& Shany, 2012:223; Harrison R., 2011:919; Peres et al., 2016: 897).

\section{Conclusions}

The image of an apparently undisturbed forest can be deceptive and may conceal more subtle threats of which we are often unaware. The causes of forest degradation (including defaunation) are dangerous, in part, because their biological effects are invisible from the air. This makes it difficult for scientists to monitor and it is therefore given little public importance and can be easily overlooked.

We must differentiate between monitoring deforestation, which largely requires the coordinated application of remote detection technology, and monitoring biological degradation, which includes the decline in wildlife or defaunation of the forests. The latter will require long-term human and financial resources across a wide network of sites (Phillips, 1997:306).

The future of tropical forest vegetation is strongly influenced by plant and animal interactions, and some animals are being seriously affected by the disturbance and deforestation of the tropical forests. Long-term conservation of tropical forest vegetation will not be possible unless the fauna is also conserved (Redford, 1992:412; Peres et al., 2016:898).

Defaunation due to overhunting has reached alarming levels, and this is now the greatest threat to tropical biodiversity (Wright, 2003:84; Harrison R., 2011:923). It is so severe that it may be putting the ecosystem functionality at risk as well as the very composition of the vegetation, resulting in a changed forest (Álvarez \& Shany, 2012:224; Redford, 1992: 15; Harrison R. 2011:923).

If we want to maintain the tropical forests, with all their desired capacity to provide financial, ecological and aesthetic benefits, including as a carbon sink, and as food security for forest peoples, we therefore have to ensure the existence of viable large animal populations (Redford, 1992:412; Peres et al., 2016:898). 


\section{BIBLIOGRAPHY}

ÁLVAREZ J. \& Shany, N. (2012). Una experiencia de gestión participativa de la biodiversidad con comunidades amazónicas. Revista Peruana de Biologia 19(2): 223 - 232.

ASQUITH, N., Wright, J. \& Clauss, M. (1997). Does mammal community composition control recruitment in neotropical forests? Evidence from Panama. Ecology, 78(3): 941-946.

BENÍTEZ-LÓPEZ, A, Alkemade, R., Schipper, A.M., Ingram, D.J., Verweij, P.A., Eikelboom, J.A. J. \& Huijbregts, M.A.J. (2017) The impact of hunting on tropical mammal and bird populations. Science, 356 (6334): 180-183.

DIRZO, R. (2011). Efectos de la defaunación de mamíferos herbívoros sobre la estructura y diversidad de la selva húmeda. Universidad Nacional Autónoma de México. Instituto de Ecología. SNIB-CONABIO Final Report, Project No. FE005. Mexico. D.F.

DIRZO, R \& Miranda, A. (1991). Altered patterns of herbivory and diversity in the forest understory: A case study of the possible consequences of contemporary defaunation. In: Price, P.W., Lewinsohn, T.M., Fernandes, G.W. \& Benson, W.W. (Eds.), Plant-animal interactions: Evolutionary ecology in tropical and temperate regions 273-287. Wiley and Sons, New York, New York. FAO (2016). State of the World's Forests 2016

HARRISON, R. (2011). Emptying the Forest: Hunting and the Extirpation of Wildlife from Tropical Nature Reserves, BioScience, 61(11): 919-924.

KANOWSKI, J., Catterall C., Dennis, A. \& Westcott, D. (2003). Animal-plant interactions in rainforest conservation and restoration. Workshop Proceedings of the Cooperative Research Centre for Tropical Rainforest Ecology and Management.

KATTAN G., Álvarez-López, H. \& Giraldo, M. (1994). Forest Fragmentation and Bird Extinctions: San Antonio Eighty Years Later. Conservation Biology, 8(1): 138-146.

LANDE, R. (1988). Genetics and demography in biological conservation. Science, 241: 1455-1460.

NASI, R. \& Van Vliet, N. (2011). Empty forests, empty stomachs? Bushmeat and livelihoods in the Congo and Amazon Basins. International Forestry Review 13(3): 355-368. ISSN: 1465-5489.

NUNEZ-Iturri, G. (2007). The effects of hunting on the regeneration of trees in mature floodplain forests in southeastern Peru. Ph.D. dissertation. University of Illinois, Chicago.

PAN, Y., Birdsey, R.A., Fang, J., Houghton, R., Kauppi, P.E., Kurz, W. A., Phillips, O.L., Shvidenko, A., Lewis, S.L., Canadell, J.G., Ciais, P., Jackson, R.B., Pacala, S.W., McGuire, A.D., Piao, S., Rautiainen, A., Sitch, S., \& Hayes, D. (2011) A large and persistent carbon sink in the world's forests. Science 333(6045): 988-993.

PERES, C.A., Emilio, T., Schietti, J., Desmoulière, S.J. \& Levi, T. (2016) Dispersal limitation induces long-term biomass collapse in overhunted Amazonian forests. Proceedings of the $\mathrm{Na}$ tional Academy of Sciences 113(4): 892-897.

PERES, C.A., Barlow, J., \& Laurance, W. F. (2006) Detecting anthropogenic disturbance in tropical forests. Trends in Ecology \& Evolution. 21: 227-229.

PERES C.A. (2001). Synergistic effects of subsistence hunting and habitat fragmentation on Amazonian forest vertebrates. Conservation Biology, 15: 1490-1505.

PERES, C.A. \& Dolman, P.M., 2000. Density compensation in neotropical primate communities: evidence from 56 hunted and nonhunted Amazonian forests of varying productivity. Oecologia, 122(2): 175-185. 
PÉREZ, E.M. \& Ojasti, J. (1996). La utilización de la fauna silvestre en la América Tropical y recomendaciones para su manejo sustentable en las sabanas. Ecotropicos 9(2): 71-82.

PETREN K. (2001). Habitat and niche, concept of. Encyclopedia of Biodiversity, Volume 3. University of Cincinnati.

PHILLIPS, O.L. (1997). The changing ecology of tropical forests. Biodiversity and Conservation, 6: 291-311.

RAMIREZ Mejía, D. \& Mendoza, E. (2010). El papel funcional de la interacción planta-mamífero en el mantenimiento de la diversidad tropical. Biológicas, 12(1): 8-13.

REDFORD, K.H. (1992). The empty forest. Bioscience 42: 412-422

REDFORD, K. H., Godshalk, R. \& Ascher, K. (1995). What about the wild animals? Wild animal species in community forestry in the tropics. FAO, Rome.

REDFORD, Kent \& Feinsinger, P. (2001). The half-empty forest: Sustainable use and the ecology of interactions. In: Reynolds, J.D., Mace, G., Redford, K.H. \& Robinson, J.G. (Eds.), Conservation of exploited species 370-399. Cambridge: Cambridge University Press.

SÁNCHEZ, A. (2002). Analysis of fragmentation effect on deer population density in relation to quality habitat for large carnivores in the biosphere reserve of Calakmul, southeast Mexico. B.Sc. Dissertation. University of East London

TERBORGH, J. (1992). Maintenance of diversity in tropical forests. Biotropica, 24(2): 283-292. TERBORGH, J., Pitman, N., Silman, M., Schichter, H. \& Nuñez V.P. (2002). Maintenance of tree diversity in tropical forests. In: Levey, D. J., Silva, W. R. \& Galetti, M. (Eds.), Seed dispersal and frugivory: ecology, evolution and conservation. 1-17. CAB International, Wallingford, UK.

TURNER, I. (1996). Species loss in fragments of tropical rain forest: a review of the evidence. Journal of Applied Ecology. 33: 200-20.

WCMC (World Conservation Monitoring Center) (1992). Global Biodiversity: Status of the Earth's Living Resources. Chapman \& Hall, London.

WRIGHT, S.J. (2003). The myriad consequences of hunting for vertebrates and plants in tropical forests. Perspectives in Plant Ecology, Evolution and Systematics, 6: 73-86. 


\title{
THE IMPACT OF DEFORESTATION ON THE WATER AND FISH POPULATIONS OF THE PERUVIAN AMAZON
}

\author{
Carlos Cañas
}

\section{Introduction}

Peru's Amazonian forests provide a range of benefits to the nation. In addition to timber and carbon storage, they provide a variety of foodstuffs in the form of fruits, edible plants, bush meat and numerous products including fibres, latex, resins and gums, all of which are extremely useful to local communities, industry and pharma. In addition, the Amazon forests also generate benefits for aquatic ecosystems, for example, by protecting the riverbanks from erosion, providing shade, and regulating the temperature of the water courses that run through them. They also play an essential role in maintaining humidity and in the water cycle. The aquatic systems and forests of the Peruvian Amazon are linked not only physically (seasonal flooding, natural erosion) but also chemically as there is a constant transfer of energy between them. The great rivers of our Amazon, which rise on the eastern slopes of the Andes, form part of the Andean-Amazon basin, and they maintain a constant yet changing relationship with the surrounding forests and vegetation along the whole length of their journey to the sea. Human populations have more recently been settling in these areas in order to extract the natural resources, which has resulted in changes in the land use in these transitional areas, and changes in the relationship between the aquatic and land-based ecosystems.

The network of tributaries of the Andean-Amazon headwaters comprises small water courses that flood in response to localised irregular and intermittent rainfall, hence their contact area with the surrounding forest remains small, mainly involving exchanges of nutrients, organic matter and surface water. In other words, in the headwaters of these tributaries, the forest regulates their temperature and contributes organic matter (falling leaves), thus shaping their chemical make-up. The forests also ensure the ebb and flow of water along the riverbeds and protect them from erosion. The rivers are fast-flowing here, with rocky beds and boulders, extreme conditions that result in a diversity of smaller yet highly endemic fish species. (Maldonado et al., 2011).

On the Amazon plains, this association between forests and aquatic ecosystems becomes much clearer. Extensive areas of floodplain forest "accompany" the large rivers, "providing refuge" for the cochas ${ }^{1}$ and swamps, characterised by their great biodiversity and fish production, fed or protected by

1. Local name given to oxbow lakes or bodies of standing water. 
the forests along their banks. Flooding is more predictable in these lower-lying areas, enabling key habitats (places of reproduction, feeding) to form that maintain this diversity. The points where tributaries join the main river form the reproduction sites for many species that are highly important due to their direct consumption by humans. The aquatic ecosystems play a direct role in the functioning and productivity of the forests, and are essential to maintaining the hydric balance of the Amazon, in addition to providing key ecosystemic services for the human populations that live in this extensive eastern region of the country. And yet our Amazonian forests have been under threat for more than four decades now due to changes in land use and human activities such as agriculture, logging, alluvial mining and, most recently, infrastructure projects such as the construction of roads and hydroelectric plants. The common denominator in all these human activities is deforestation and this not only results in a loss of the biodiversity and environmental services of the forest itself but also has a direct effect on the quality of the water, resulting in deteriorating aquatic habitats and declining aquatic biodiversity. Deforestation is continuing apace in our Amazon basin, contributing to an increase in suspended sediments and the subsequent sedimentation of the water courses, which has a severe impact on the streams and small rivers that form part of the drainage basin of the great Amazonian rivers that rise in the Andean piedmont (foothills). Deforestation in the lowest reaches of these rivers is reducing the abundance and diversity of the highly-productive riverine plant species that maintain the high diversity and productivity of the fish populations of the Amazon plains, and is also resulting in much greater flooding, degrading the basins and reducing the quality of life of local communities (Arantes et al., 2017).

Globally, more than $80 \%$ of the lands associated with freshwater ecosystems have been significantly altered by humankind. And yet conservation actions aimed at halting these changes, particularly deforestation, have been largely directed at land-based ecosystems and their biodiversity, establishing community management or protected area systems, for example. In contrast, little has been done to highlight the effects of deforestation on the aquatic environment and its associated wildlife, or to take action aimed at preserving its extraordinary biodiversity. This article seeks to describe the main effects of deforestation in the Peruvian Amazon on the aquatic ecosystems by presenting the country's patterns of deforestation, describing the diversity of fish species and how they relate to the riverine forest and, finally, explaining the effects along the elevation gradient of our Amazonian rivers.

\section{Deforestation in the Peruvian Amazon}

Deforestation is a growing problem in Peru although still relatively low compared to other Amazonian countries (less than $0.23 \%$ ). The main causes include State or corporate policies that encourage settlement in the Amazon through road building and the grant- 
ing of agricultural loans. Agriculture and livestock farming are the primary causes of the country's loss of riparian forests (National Forest Conservation Programme, 2016).

Peru's forests cover $56.9 \%$ of the national territory, with the greatest forest cover found in the Peruvian Amazon (53.06\% of the national area), followed by the Andean dry forests (National Forest Conservation Programme, 2016). The forests offer benefits for the well-being of Amazonian communities, providing them with basic supplies such as timber, food and a range of products that guarantee their livelihoods. On a national level it should be noted that the forests also provide clean air and clean water, biodiversity and, with a view to the future, are considered to be of significant importance in mitigating the effects of climate change. Over the last three years, deforestation has escalated in Peru, largely as a consequence of the search for land on which to practise livestock and agricultural farming although, compared with other Amazonian countries, it remains at a relatively low level.

Between 2001 and 2014, Peru lost 1,653,129 ha of Amazon forest, a rate of $118,080,10 \mathrm{ha} /$ year. The area being deforested in the Peruvian Amazon continues to grow and the main reasons are agricultural expansion $(51.6 \%)$, illegal and informal extraction, such as mining $(5.8 \%)$, expanding communication infrastructure $(0.3 \%)$, small and large-scale livestock farming (39.9\%), coca growing $(2.3 \%)$ and the unregulated extraction of timber products (National Forest Conservation Programme, 2016).

The regions with the highest levels of deforestation over this period were San Martín, Loreto (around Yurimaguas), Huánuco, Ucayali, Pasco (Federico Basadre and Marginal de la Selva highways) and Madre de Dios (inter-oceanic highway and illegal mining zones) (National Forest Conservation Programme, 2016). These zones have affected the drainage network of the headwaters of the Ucayali and Marañón basins (that form the Amazon River) and of the Madre de Dios river basin in the south-east of Peru, with these effects being concentrated primarily on an elevation range of between 200 and 800 metres above sea level (m.a.s.l.). This elevation gradient represents the area of greatest erosion of the Amazonian rivers, being the origin of a large amount of sediment and nutrients, which is incorporated into the rivers every year to be transported down to and deposited on the Amazon plains (at an elevation of less than 200 m.a.s.1.). This is also the area in which the highest rainfall occurs and the dense montane forest, whose cover plays an essential role in controlling the erosion, provides shade and facilitates links between the external food chains related to the rivers and streams.

These deforestation processes are closely associated with economic activities, with a migrant population that is moving with commercial expectations rather than a focus on rational use. This is an issue that is magnified by a lack of development policies in line with the Amazonian reality, by the existence of unsustainable models of agricultural production given the low nutrient level of the Amazonian soil, and by a poor government structure and limited financial - and non-financial support for producers who have to resort to surviving at the cost of felling more and more forest to create further space on which to farm. This uncontrolled settlement of 
areas of the Peruvian Amazon, and their subsequent deforestation, has also been encouraged by the presence of new roads connecting the eastern side of the country with the Andes and the Peruvian coast and which have, in one way or another, promoted the development of illegal extraction activities such as the mining in Madre de Dios, giving rise to social conflict between these extraction companies and the indigenous communities. In some regions, these migration and deforestation processes have resulted in conflicts and the displacement of native communities, the very people who use the forest in a more sustainable way (Gallice et al., 2017).

\section{Amazonian fish and riparian forest}

Peru's Amazonian rivers are home to more than 800 of the 1,010 species known to the country's continental waters. Most of them are found on the Amazon plains (below 500 m.a.s.l.) while at elevations of more than 1,000 m.a.s.l. there are no more than 80 species (Ortega et al., 2010). Up to 100 species have been reported on sale in the ports of the main Amazonian cities (Iquitos, Yurimaguas, Pucallpa and Madre de Dios) for human consumption. Fishery resources in the Amazon are a primary source of animal protein, thus contributing to the region's food security. They are also a source of economic income for the riverine communities who sell fish either for consumption or for ornamental use. The wealth of species is different in each of the country's river basins and is determined primarily by geographic factors (latitude, climate, elevation), encouraging the creation of a wide diversity of aquatic habitats, and also by their conservation status or level of anthropogenic influence. In other words, given their great biodiversity, the country's fisheries represent one of the main ecosystemic services that the Amazonian rivers have been providing to the local population for thousands of years. In addition to fisheries, the Amazon's aquatic ecosystems obviously also provide transportation routes and a daily source of water, both important for riverine communities and which may also be affected by deforestation. More than $80 \%$ of fish species for human consumption in the Amazon are migratory; in other words, they travel annually to fulfil different vital functions that enable them to maintain their populations and, thus the production of fish. The greatest risk facing the Peruvian Amazon's ichthyofauna is a change in or destruction of their habitats due to alterations in the hydrological system and deforestation. They migrate in response to hydrological conditions and the quality of habitats. Physical alterations or a change in water quality due to deforestation will therefore have a negative effect on populations of species that are used as food by the local communities or which represent an economic income for them through their sale to others. Species such as the Gilded Catfish (Brachyplatystoma rouseauxii) need to reach the headwaters of the rivers; others such as Black Prochilodus (Prochilodus nigricans), which lives in the floodplain forests, move to the confluence of the trib- 
utaries and the main river to reproduce. Some fish also move to find food, particularly in the lower reaches of the basins, where the close relationship between the river and the forest truly emerges. The diet and feeding habits of species such as the tambaqui (Colossoma macropomum), sábalo (Brycon sp.), Silver Arowana (Osteoglossum bishirossum), tucunaré (Cichla monoculus), and mullet (Schizodon and Leporinus genera) are based on fruits, seeds, leaves, flowers, wood, invertebrates, the larvae of aquatic insects and snails all coming from the adjacent land-based vegetation.

Species such as Black Prochilodus, llambina (Potamorhina altamazonica) and chio (Psectrogaster routiloides), which account for almost $80 \%$ of the total capture in Loreto and Ucayali, feed primarily on detritus coming from the organic matter that falls from the surrounding trees. Detritus, a generic term referring to any kind of decomposing organic matter that accumulates on the bed or on substrata such as submerged trunks, formed from the decomposition of leaves and other structures falling into the water from adjacent trees, is an important source of food for fish populations. The maintenance of floodplain habitats and vegetation, and their protection from deforestation, is therefore vital not only to maintain the production of important consumption species, but also of large migratory fish (mostly large catfish and fish-eating species) that feed on small and medium-size fish on their journey to their reproduction zones in the headwaters. Deforestation can thus also have regional effects if we take the effects on fishery resources as a whole into account.

\section{The impact of deforestation on water and fish}

Deforestation has a direct impact on the integrity of rivers and streams. The destruction of riverbank vegetation, increased rates of erosion and excessive amounts of sediment being deposited along the water courses are all drastically altering the diversity of habitats. In the Peruvian Amazon, the effects of deforestation vary in size depending on the causal factor and the water / forest relationship along the course of each basin. Generally, however, in montane forest and in the foothills of the Andes, deforestation results in changes in the hydrology of the headwaters of the rivers and tributaries and alterations in water quality (bodies of water with low sedimentary content), and has an effect on aquatic biodiversity (endemic species). On the Amazon plains, in the streams and small rivers that run through the forest, it will have an effect on water quality, temperature and the composition of fish diversity, while on the floodplains the effects will result in a decline in the abundance and diversity of plant species and in the food chains of fish communities.

To adequately understand the effects of deforestation on fish and aquatic systems, we need to understand the relationship between rivers and plant formations along the gradient of elevation of their journey down through the basin, and how the associated aquatic wildlife also varies along this descent in terms of diversity, endemism and fish production. The rivers of the Peruvian Amazon rise on the 
eastern side of the Andes and travel down an elevation of more than 4,000 $\mathrm{m}(+4,000$ - 100 m.a.s.l.), always accompanied by highly varied plant formations, from the high Andean grasslands (at more than 3,000 m.a.s.l.), steep montane forest to the foothills of the Andes (2,500 - 500 m.a.s.l.), to finally cross the extensive floodplain forest of the Amazon plains ( $<500$ m.a.s.l.). It is from 2,500 m.a.s.l. onwards that the presence of montane forest begins to demonstrate the forest's relationship with the rivers, which at these heights are characterised as small to medium, with clear waters and a rocky substratum. Such is the case of the Araza and Upper Madre de Dios rivers (Madre de Dios basin); Iscozacín, Pichis, Perené, Satipo, Aguaytía, Upper Urubamba (Ucayali basin); and Mayo and Medio Huallaga (Marañón River basin). In the lowlands, below 500 m.a.s.l., run the courses of the great rivers such as the Urubamba, Ucayali, Marañón, Pastaza, Tigre, Napo, Madre de Dios, Tambopata and Heath, characterised by their deep beds, transporting a large amount of sediment and linked to the adjacent forest that they seasonally flood (floodplain forest).

In the upper reaches with forest presence, the expansion of the agricultural frontier has forced the steep environment into use for crop growing and, in some cases, livestock rearing. The main causes of deforestation are the roads, the advance of the agricultural and livestock frontier, logging and coca growing, all of which have direct effects on the river discharge and on the geomorphological and biogeochemical conditions of the tributaries, given the increased sediments entering these aquatic systems from the land (Castro et al., 2008).

The increased discharge of sediments has resulted in reduced habitat diversity and a subsequent decline in invertebrates; this has consequences for fish who feed on these invertebrates. It is also important to note that there is high diversity and species endemism in these upper reaches, as a result of the dynamic hydrological conditions on the eastern side of the Andes. Twenty-six and 30 species respectively have been reported in the upper reaches of the Marañon and Ucayali basins (Maldonado et al., 2011). Given the effects of deforestation, there is therefore a significant likelihood of a loss of species from the Chaetostoma, Trichomycterus and Atroblepus genera. In the region of San Martín, the Alto Mayo basin has suffered the worst rates of deforestation, with significant effects in terms of reducing the flow of the Uquihua and Yuracyacu rivers and on the aquatic diversity of the tropical cloud forest (Gonzales Inca and Llanos López, 2015). Deforestation in this region has been encouraged by the expansion of cash crops for export, such as coffee and cocoa, followed by livestock farming and logging. Another area of high deforestation can be found in the central forest, between the regions of Ucayali, Huánuco and Pasco, primarily in the area of influence of the highway, where the establishment of human settlements and livestock activities have drastically altered the banks of the Pachitea River, with a significant decline in the characteristic trees usually found there, such as bobinsana (Calliandra angustifolia) and shihuahuaco (Dipteryx micrantha), and with effects on the key habitats of the fish species that live there (Ayllón, 2002; Castro et al., 2008). The use of explosives in 
the construction of the highway from Villa Rica to the Pichanaz River, in the same catchment area as the Pachitea, led to significant silting up of the river with rocks and sand. This has had a direct effect on the migration of the Black Prochilodus (Prochilodus nigricans) which used to reach these heights, despite the presence of rapids and the low temperatures in this part of the basin. The effects were felt not only on the ecology and populations of Black Prochilodus but also on the availability of fish for the local communities of Loma Linda, Santa Rosa and Lagunas (Ayllón, 2002; Bayley, 1981; Castro et al., 2008).

In the south-east of the country, in the Madre de Dios river basin, alluvial gold mining, a legal activity that often takes place along the basin's tributaries but which has primarily been concentrated on the Caychihue and Colorado rivers, has significantly affected the aquatic ecosystems by causing significant sedimentation of the water bodies, making the presence of ichthyofauna that support these conditions unviable. The construction of the inter-oceanic highway has resulted in a significant increase in human migration and settlement of the Amazon plains, which has encouraged further penetrative road expansion, with deforestation and forest degradation reported up to $18 \mathrm{kms}$ from its route (Gallice et al., 2017; Southworth et al., 2011). These effects have most likely reached water bodies important to the local communities, such as the Jayave stream, and for fish populations such as the sábalo (Brycon sp.) which, at the end of the 1990s, this author managed to catch during work conducted with Conservation International Peru. The deforestation process along this highway will continue given the continuing transit and arrival of immigrants into the zone.

At least one-third of the fish biomass in the tropical rivers is sustained by the primary production of riverine forests, organic matter from which (leaves and branches) is not only a source of energy, but also determines the water quality and temperature of the water bodies; any reduction in the energy and nutrients being contributed to the aquatic systems will therefore affect their functioning and the ecosystemic services they provide. There is no data in the Peruvian Amazon linking deforested areas of floodplain forest to fisheries production. It is, however, obvious that clearing these sections will destroy fish habitats and reduce the populations of fish, most of which are important for human consumption, such as Black Prochilodus and sábalo, which rely on the fertility of the floodplain forest. In the Brazilian Amazon, it was found that the demographic increases of the 1990s increased not only the deforestation of the floodplain forest but also the pressure on fishery resource extraction (Barthem, 1999). In the Peruvian Amazon, more than a million people depend on these fisheries production which relies, in more than $70 \%$ of cases, on the extensive floodplain forests. In other words, deforestation could even have an effect on the availability of the main source of animal protein and food security in the region.

Deforestation of the floodplain forest is also resulting in a reduction in the diversity of fish communities and in functional diversity, both at the local and regional 
level. This can be explained by the direct food relationship that exists between the main fish populations and the forest, for example, frugivores (tambaqui, palometa, mullet), detritivores (Black Prochilodus, llambina) and insectivores (arowana). These communities of fish feed on allochthonous matter coming from the surrounding riverine forest.

In the Madre de Dios basin, mining is the main cause of deforestation. This is undertaken primarily on alluvial terraces, considered to be areas of great biological productivity, and which hold stocks of fish that have long been a source of protein for the indigenous and non-indigenous populations living along the banks of these rivers. These alluvial terraces in Madre de Dios are located in the area of influence of the reproductive zones of large migratory catfish (Barthem et al., 2003, 2017; Cañas and Pine, 2011). The deforestation caused by mining not only leads to habitat destruction and high sedimentary deposits in the water bodies but also produces changes in the hydrological flows, which determine the reproductive migrations of these species to the places where they spawn and will therefore have an effect on these species' populations. It is important to note that the species that arrive annually in the Madre de Dios basin to reproduce use the Amazon basin to complete their life cycle; in other words they also form part of the fisheries of basins (and countries) located "hundreds of kilometres downstream" and so the effects of deforestation in this part of the basin will have repercussions very far away.

In the streams and small rivers that cross the forests, deforestation directly affects habitat quality in terms of the minimal values of suspended sediment, low temperatures due to forest shade and the constant provision of organic matter that the trees provide. The fish communities are very different to those in the large rivers and endemic species have sometimes been recorded, such as the case of the Corydoras genus, meaning that these aquatic environments are facing the serious risk of losing unique species. Medium and small-scale mining is found in a large part of the basin, and both cause deforestation and the sedimentation of rivers (Montag et al., 2007), with a greater effect on the tributaries that cross the terrace forest and swampland. The swamps of Madre de Dios are found primarily in the former basin depressions and are home to communities of fish very similar to those of the terrace streams, species with different colour patterns, associated with minimal levels of sedimentation and low water temperatures (due to the shade given by the swamp palms). In recent years, mining has destroyed these swamplands by felling the palms and dredging and removing the river beds, adding high volumes of sediment and leaving areas of open water, commonly known as "wells", exposed to high temperature due to the effects of the sun, filled with sludge, sand and boulders, and with minimal or very poor fish communities adapted to conditions of high sediment.

As a final consideration, I must note that deforestation in the Peruvian Amazon causes direct effects on the quality of aquatic habitats, which results in a significant loss of fish diversity and productivity, both locally and regionally. We 
are seeing an increasing pattern of deforestation, and there will be a concomitant degradation of habitats and change in land use, which will affect the wetlands and bodies of water, in particular key habitats used by the fish to complete their vital functions and maintain their populations. It is already known that fish populations can recover from situations of local overfishing but they will not be able to recover from the drastic alteration or loss of habitat being caused by deforestation and changes in the hydrological system. There is a clear need to maintain substantial cover of riverine or floodplain forest in the Amazon, and to recognise that the loss of forests also affects the livelihoods of our Amazonian brothers and sisters and, in particular, the indigenous populations.

The infrastructure projects proposed for a number of Amazonian regions, such as new roads, railways, transmission lines, hydroelectric power stations and waterways, are going to encourage the destruction and fragmentation of forests and open up new spaces that will promote drastic changes to many of our regions' bodies of water. I cannot finish without noting that both national and regional policies and regulations' criteria for evaluating the impacts of infrastructure development on water bodies lack proposals that would include recognising the significant benefits the wetlands provide in the Amazon. It is therefore recommended as a critical issue that more attention be given to the aquatic systems and that their classification and rating should be encouraged as part of the region's development. Protecting the fish populations and their aquatic habitats from the current method of infrastructure development and occupation of the Peruvian Amazon will depend on the balance that can be achieved between maintaining the economic value of the ecological functions and the value of ecosystemic services provided by aquatic environments.

Deforestation also contributes to greenhouse gas emissions. The felling and burning of forest for agricultural or mining purposes contributes to this either independently or through its interaction. Forest conservation is also essential for climate change adaptation and mitigation. One of the forest's environmental services is its key participation in the water cycle in this tropical region, critical also as a source of benefits for the Amazonian communities of our country who have always lived in close association with the forests and water courses. The changes that are occurring in rainfall patterns in the region and globally suggest there will be increased precipitation in the western region of the Amazon basin (Peruvian Amazon); this will result in increased run-off or surface flow, an effect that will be magnified yet more with further deforestation. 


\section{BIBLIOGRAPHY}

ARANTES, C.C., Winemiller, K.O., Petrere, M., Castello, L, Freitas, C.E.C., Hess, L. (2017). Relationships between Forest Cover and Fish Diversity in the Amazon River floodplain. J. Appl. Ecol. doi:10.1111/1365-2664.12967.

AYLLÓN, R.L. (2002). Evaluation of the Use and Management of Fish Resources in the Pachitea River Basin, Peruvian Amazon (Master's Degree Thesis). Florida International University, Miami, Florida. 2002.

BARTHEM, R.B., Goulding, M., Leite, R.G., Cañas, C., Forsberg, B., Venticinque, E., Petry, P., Ribeiro, M.L. de B., Chuctaya, J., Mercado, A. (2017). Goliath catfish spawning in the far western Amazon confirmed by the distribution of mature adults, drifting larvae and migrating juveniles. Scientific Reports 7, 41784.

BARTHEM, R.B. (1999). Várzea fisheries in the middle Rio Solimões. In: Padoch, C., Ayres, J.M., Pinedo-Vázquez, M., Henderson, A. (Eds.). Várzea: Diversity, Development, and Conservation of Amazonia's Whitewater Floodplains. New York Botanical Garden Press, Bronx, pp. 7-28.

CAÑAS, C., Pine, W. (2011). Documentation of the temporal and spatial patterns of Pimelodidae catfish spawning and larvae dispersion in the Madre de Dios River (Peru): insights for conservation and the Andean-Amazon headwaters. River Research \& Applications. 27, 602-611. doi:10.1002 / rra.1377.

CASTRO, E., Borios, S., Summers, P. (2008). La pesca en la cuenca andino-amazónica del río Pachitea, Perú. In: Pinedo, D., Soria, C. (Eds.), El Manejo de las Pesquerías en Ríos Tropicales de Sudamérica. Mayor Ediciones S. A., Bogotá, Colombia, pp. 39-74.

GALLICE, G.R., Larrea-Gallegos, G., Vázquez-Rowe, I. (2017). The threat of road expansion in the Peruvian Amazon. Fauna \& Flora International, 1-9. doi:10.1017/S0030605317000412.

GONZALES Inca, C.A., Llanos López, R. (2015). Evaluación de los efectos de la deforestación en la hidrología y pérdida lateral de carbono orgánico del suelo de la cuenca Alto Mayo (Reporte Técnico). Lima.

MALDONADO, M., Maldonado-Ocampo, J.A., Ortega, H., Encalada, A.C., Carvajal-Vallejos, F.M., Rivadeneira, J.F., Acosta, F., Jacobsen, D., Crespo, Á., Rivera-Rondón, C.A. (2011). Biodiversity en Aquatic Systems of the Tropical Andes. In: Herzog, S.K., Martínez, R., Jorgensen, P.M., Tiessen, H. (Eds.), Climate Change and Biodiversity in the Tropical Andes Inter-American Institute for Global Change Research (IAI) and Scientific Committee on Pro-blems of the Environment (SCOPE). San José dos Campos, pp. 276-294.

MONTAG, L., Silva, R.D., Barthem, R. (2007). The destruction of freshwater habitats: the case of the Amazon Basin. Presentado en el Congreso de Ecología de Brasil. Caxambu, Minas Gerais, p. 2. ORTEGA, H., Hidalgo, M., Correa, E., Espino, J., Chocano, L., Trevejo, G., Meza, V., Cortijo, A.M., Quispe, R. (2010). Lista Anotada de los Peces de Aguas Continentales del Perú: Estado actual del conocimiento, distribución, usos y aspectos de conservación, Dirección General de Diversidad Biológica. Ministerio del Ambiente. Perú. ed. ASKHA E.I.R.L., Lima. PROGRAMA NACIONAL DE CONSERVACIÓN DE BOSQUES (2016). Mapas Kernel como indicador de la concentración de la pérdida de bosques húmedos amazónicos de Perú.

SOUTHWORTH, J., Marsik, M., Qiu, Y., Perz, S., Cumming, G., Stevens, F., Rocha, K., Duchelle, A., Barnes, G. (2011). Roads as Drivers of Change: Trajectories across the Tri-National Frontier in MAP, the Southwestern Amazon. Remote Sensing. 3. doi:10.3390/ rs3051047. 125 


\title{
THE CHALLENGES FOR ACHIEVING CONSERVATION AND SUSTAINABLE DEVELOPMENT WITHIN THE WETLANDS OF THE PASTAZA-MARAÑÓN BASIN, PERU
}

\author{
Timothy R. Baker, Dennis del Castillo Torres, \\ Eurídice N. Honorio Coronado, Ian Lawson, Manuel Martín Brañas, \\ Mariana Montoya, Katherine Roucoux
}

The wetlands of the Pastaza-Marañón basin in northern Peruvian Amazonia are record-breaking: situated in the centre of one of the largest remaining areas of intact forest on the planet, they contain the largest known peatland complex in Amazonia. Thick layers of organic matter accumulate where the soil remains constantly wet and the large quantities of below-ground carbon make these the most carbon-dense of all Amazonian forests. These wetlands also have a multi-millennial history of occupation by indigenous people who hold a rich knowledge of the forests and their uses. Today, extensive natural stands of a renewable, bountiful and valued resource - the Mauritia flexuosa palm - help to sustain local communities along the myriad rivers which cross the landscape. However, this region also faces threats from the chronic damage caused by oil pollution and the uncertain implications of planned infrastructure developments. These forests therefore also pose one of the key questions for conservation today: how can substantial areas of intact tropical forest be sustained over the coming decades, whilst also supporting and improving the livelihoods of the people who live there?

The purpose of this article is to address this question by firstly documenting the history of the scientific exploration of these ecosystems, which helps to place these wetland forests in their regional and global context. Secondly, we explore our emerging knowledge of the relationships these forests have with people. In particular, we discuss the threats faced by these communities and their forests and the actions that are required to ensure that these ecosystems are sustainably managed and persist into the future.

\section{The history of the biological description of the wetlands}

From the 1970s onwards, the forests of the northern Peruvian Amazon attracted interest from ecologists in search of the most diverse tropical forests because of their very high species richness (Gentry, 1988; Vásquez Martínez, 1997). Ecologists marvelled at the high alpha (ie local) diversity of the plots they studied in upland, non-flooded, terra firme forests of the region, where tree species richness of 
forests on the most fertile soils can exceed 300 species per hectare (Gentry, 1988). Subsequently, the description of the unique biodiversity of the forests that grow on patches of upland, white sand soils led to the recognition that this region contains not only some of the most diverse forests in the world at the scale of individual plots but also extremely high diversity at the scale of landscapes - in other words, high beta diversity (Tuomisto et al., 1995; Fine et al., 2005). A paradigm of high diversity, at both point and landscape scales, was therefore established for these western Amazon forests.

In contrast to their diversity, the upland forests of this region are not particularly remarkable in terms of above-ground carbon stocks. These forests contain approximately $135 \mathrm{Mg} \mathrm{C} \mathrm{ha-1}^{-1}$ (Baker et al., 2004a) - a high value compared to drier tropical ecosystems or many temperate forests, but markedly lower than the highest aboveground biomass forests of Amazonia which occur on the Guiana Shield (with typically >200 Mg C per ha; Johnson et al., 2016), and lower than typical values for African and Asian moist tropical forests (Sullivan et al., 2017b). Even the grandest upland forests of the western Amazon contain trees that are not particularly tall, or of particularly large diameter, or of species with particularly dense wood, compared to many other moist tropical forests. The wetland forests of the Pastaza-Marañón basin are usually even shorter in stature, thinner, and more open than the upland forests, so it is no surprise that biomass maps based on remote sensing data show the Pastaza-Marañon basin as a 'black hole' with low values of above-ground carbon (Asner et al., 2014).

These perspectives on the forests in this region were, however, overturned by the scientific exploration of the peatlands of the Pastaza-Marañon basin. The story of the on-going biological description of these wetlands illustrates the formative role that unanticipated observations play in scientific discovery and the value of bringing perspectives from other regions and fields of investigation to understand what lies in front of us. It also reminds us of how our research builds on the work of others and how insights that are each based on innovative and pioneering measurements and observations accumulate over time to transform our knowledge.

The possible presence of extensive peatland areas in the wetlands of western Amazonia was first noted in the scientific literature by Kalle Ruoklainen, Leif Schulman, and Hanna Tuomisto (Schulman et al., 1999; Ruokolainen et al., 2001). These publications were based on a series of conversations and field observations during the 1990s: Juan Ruiz Celidonio had mentioned to them of an open swamp with Sphagnum moss and peat near the Rio Ucayali, and they themselves had also found at least two metres of peat in a palm swamp in Yasuní, Ecuador in 1997, which demonstrated the potential of these ecosystems to accumulate large amounts of organic matter. In addition, with other colleagues from Finland, they had participated in the first broad description of the wetlands of the Peruvian Amazon based on overflying the region and speculated on the possible presence of peat (Kalliola et al., 1991). These biologists had a background of studying the 
northern boreal biome, where peatlands are generally expected to form under specific waterlogged conditions. For them, the scattered observations of peat in Amazonia were a strong indication that the decomposition of organic matter is impeded by the same factors in the tropics as in the boreal zone, despite the common wisdom of the time, which held that decomposition in the tropics is so efficient that peat cannot form.

Independently, Dennis del Castillo, who had begun to work at the Instituto de Investigaciones de la Amazonia Peruana (IIAP) in the 2000s, realised the capacity of the almost monodominant stands of Mauritia flexuosa to accumulate organic matter, based on his observations of organic matter accumulation beneath oil palm plantations in Nigeria. At IIAP, Guzmán (2004) carried out a preliminary economic valuation of the environmental benefits of sustainable wetland management including some field data collection, and subsequently Dennis del Castillo and colleagues made the study of the carbon stocks of the palm swamps a research priority. This step led to the first project, funded by INCAGRO, to measure the below-ground carbon stocks of these ecosystems, led by Luis Freitas. The results were a revelation: these observations suggested that these forests could harbour remarkable quantities - more than $600 \mathrm{MgC} \mathrm{ha}^{-1}$ - of carbon below the ground stored as peat (Freitas et al., 2006), far in excess of estimates of the aboveground biomass of nearby upland forests.

The work led by IIAP (Freitas et al., 2006) and the observations and estimates of Schulman et al. (1999) and Ruokolainen et al. (2001) were largely independent lines of enquiry, but were both linked as responses to the emerging recognition of the importance of terrestrial carbon stocks as a key regulator of the global carbon cycle during the 1990s: Schulman et al. (1999) was a direct response to the need to model the different terrestrial carbon pools in the tropics with greater precision (Tian et al., 1998), and Freitas et al. (2006) was framed in terms of the possibility of accessing payments for carbon storage as an ecosystem service. Whilst Dennis del Castillo's observation focussed on the high productivity of these ecosystems, Ruokolainen et al. (2001) focussed on how the waterlogged would slow down the rate of decomposition. Together, these two observations demonstrated the key condition that is required for the presence of peat: that, on average, the rate of organic matter production must exceed the rate of decomposition.

These early publications and observations inspired efforts to measure the carbon stocks of these largely permanently flooded forests in more detail and across more sites. Kalle Ruokolainen and Hanna Tuomisto suggested that Amazonian peatlands would be an ideal research topic for Outi Lähteenoja who sought a challenging research question related to Amazonian ecology. The result was a landmark study that quantified through a pioneering series of transects across these ecosystems the substantial and extensive carbon deposits that lie beneath them (Lähteenoja et al., 2009b). Subsequently, interest in these ecosystems began to broaden, and IIAP continued to play a central role within this research. Eu- 
rídice Honorio, at IIAP, established permanent forest inventory plots in the palm swamps around Jenaro Herrera, which had previously been ignored by ecologists simply because of the difficulty of working in these areas, in order to study their structure and dynamics (Honorio-Coronado et al., 2015). Katy Roucoux, Ian Lawson and Tim Baker viewed the deposits of organic matter as an opportunity to apply palaeoecological methods, particularly analysis of the pollen preserved in the peat, to understand the role that past disturbance by humans played in causing nearby upland forests to accumulate carbon (Baker et al., 2004b, Roucoux et al., 2013; Kelly et al., 2018). Freddie Draper added his interest in forest ecosystems and remote sensing to the expanding knowledge of variation in floristic composition and peat thickness in the region, and mapped the distribution of different vegetation classes for the first time and their associated carbon stocks (Draper et al., 2014). Remarkably, when the below-ground carbon stocks are considered, one of these vegetation types - a small stature forest growing on the thickest peat deposits - contains the highest concentration of carbon of any vegetation in Amazonia (1391 $\pm 710 \mathrm{Mg} \mathrm{C} \mathrm{ha-1}^{-1}$; Fig. 1; Draper et al., 2014). Overall the peatland complex contains over 3 billion tonnes of carbon below the ground, which is equivalent to 62 years of annual greenhouse gas emissions from human activities in Peru (MINAM, 2016).

Figure 1

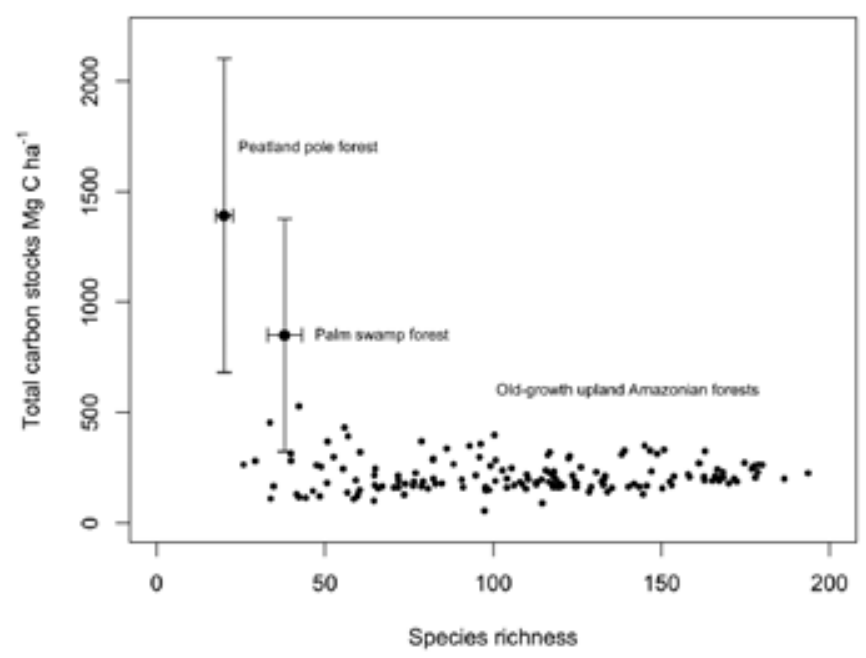

Figure 1. Estimates of total carbon stocks and species richness for peatland pole forest and palm swamps from the Pastaza Marañón basin (Draper et al., 2014; Draper et al., 2018) and for 157, one hectare upland forest plots from across Amazonia and the Guiana Shield (Sullivan et al., 2017a; Sullivan et al., 2017b). Aboveground carbon stocks in these studies are for all trees $\geq 10 \mathrm{~cm}$ diameter and 
exclude coarse woody debris, leaf litter and trees $<10 \mathrm{~cm}$ diameter. Aboveground biomass values as dry weight from Sullivan et al. (2017b) were converted to carbon using an average carbon content across angiosperm species of $47 \%$ (Sullivan et al., 2017b). Belowground stocks to $2 \mathrm{~m}$ depth for the sites in Sullivan et al. (2017b) were estimated as 54\% of the aboveground values, based on the average below: aboveground ratio of carbon stocks of the same pools for three Amazonian sites (Malhi et al., 2009; Quesada et al., 2011). Values of total carbon stocks for the wetland forests include the surface peat deposits with an average depth of $3.15 \mathrm{~m}$ in peatland pole forest and $1.73 \mathrm{~m}$ in palm swamps (Draper et al., 2014). Species richness values are standardised as the number of species per 300 stems for the upland sites (Sullivan et al., 2017b) and as the number of species per 500 stems for the peatland pole forest and palm swamp (Draper et al., 2018); species richness values are therefore slightly overestimated in the wetland compared to the upland sites. Estimates for the wetland forests are mean values $\pm 1 \mathrm{SE}$.

The biodiversity of the forests of the Pastaza-Marañón basin also attracted attention as it was clear that these systems were not only carbon-dense, but that they also contained some unusual and poorly known vegetation types (Lähteenoja et al., 2009a). In particular, the most carbon dense, ombrotrophic peatlands share species of trees (Draper et al., 2018), ferns (e.g. Lindsaea divaricata; Lehtonen \& Tuomisto, 2007) and, based on the fieldwork of Jose Alvarez, birds (Lähteenoja et al., 2009a) with forests growing on upland, white sand soils in the region. This peatland forest type, now known in the literature as 'varillal hidromorfico' or 'peatland pole forest', was first informally recognised and named by Filomeno Encarnación, also at IIAP, who produced the first key to the different forest types of the Peruvian Amazon (Encarnación, 1985). Although not described in the published key, he had recognised that the forests on the western bank of the Amazon near Tamshiyacu, south of Iquitos, were unusual; they shared the structural characteristics of the similarly resource-poor white sand forests in containing many small diameter trees, but the soils were waterlogged and rich in organic matter, rather than consisting of sand. In addition, the alpha diversity of these permanently waterlogged forests was also notably low in the context of surrounding upland forests: Mauritia flexuosa can form almost monodominant stands (Honorio-Coronado et al., 2015), and the peatland pole forests is the most species-poor old-growth tropical forest known in Amazonia (Fig. 1; Draper et al., 2018).

Overall, these findings turned the paradigm of high diversity and relatively low above-ground carbon stocks in northwestern Amazon forests on its head. In fact, these forests are now known to contain some of the least diverse tropical forests and, rather than being an area of low carbon stocks, the Pastaza-Marañón basin is the hotspot for carbon storage across the whole of Amazonia. The only element of the original paradigm that the description of these wetland forests has enhanced is that their existence further increases the already very high, landscape-scale, beta diversity of northern Peruvian Amazon forests (Draper et al., 2018). 


\section{The wetlands of the Pastaza-Marañón basin in a global and regional context}

While their biodiversity and carbon storage are clearly exceptional, the wetland forests of the Pastaza-Marañón basin are also distinctive in terms of the processes that underlie their formation, compared to other wetlands in Amazonia and to tropical peatlands across the globe. The magnitude $\mathrm{M}_{w} 8$ earthquake in June 2019 centred at Lagunas on the southwestern edge of the peatland complex reminded us of the primary underlying reason for the existence of these ecosystems in this particular region of the Peruvian Amazon: they occur here because of the tectonic activity and on-going subsidence during the Quaternary that has led to the formation of the Ucayali-Marañón (or Ucamara) and Pastaza depressions (Dumont \& Fournier, 1994; Dumont, 1996). These depressions are part of the Andean foreland basin which formed due to flexing of the continental lithosphere on the eastern edge of the Andes (Beaumont, 1981; Dumont, 1996). These ripples in the lithosphere are attributed to both the eastern movement of the Andes into the Brazilian Craton and as a reaction to the vertical, downward force of the uplifted Andes to the west of the Pastaza-Marañón basin (Beaumont, 1981; DeCelles \& Giles, 1996; Dumont, 1996). The location of these depressions in the one of the highest and aseasonal rainfall areas of Amazonia and at a collecting point for water from Amazonian tributaries from a large part of western Amazonia, has created the permanent waterlogging required for peat formation. This a globally unique context for tropical peatlands: the peatlands of SE Asian forests occur in similarly high rainfall areas, but the largest peatlands are found in coastal areas and poor drainage there is linked to sea-level rise since the end of the last glacial period (Page et al., 2006), whilst those of the Congo basin appear to have formed in a shallow but stable interfluvial basin (Dargie et al., 2017).

It is also important to note that the combination of ecosystems in the Pastaza-Marañón basin - a mosaic of permanently waterlogged and peat-forming palm swamps, peatland pole forests and open peatlands, as well as seasonally flooded forests which are typically not associated with peat formation - is very different from the two other major areas of wetland vegetation in the Amazon basin: the seasonally flooded forests that occur in central Amazonia, along the main stems of the Negro, Solimões and Amazon rivers, and the grassland-dominated Llanos de Moxos, in Beni, Bolivia (Hess et al., 2015). In simple terms, the wetland forests of the Pastaza-Marañón basin are often permanently waterlogged, whereas the Brazilian flooded forests experience a very strong flood pulse and experience strong seasonal contrasts in water levels. The maximum seasonal fluctuation in river levels in the wetlands of the Pastaza-Marañón basin, in the higher reaches of Amazonia, is much lower than a floodpulse that can exceed $10 \mathrm{~m}$ along some Brazilian rivers in central Amazonia (Junk et al., 2011). Of course, there is substantial variation within both regions depending on the local context of the sites, but this difference means that although both areas of wetland contain forest, the adaptations that spe- 
cies require, floristic composition, and tendency for the wetlands to be associated with peat formation, are very different. For example, whereas peat formation is common in the Pastaza-Marañón basin, it has been observed only rarely in central Amazonia (Lähteenoja et al., 2013), despite model predictions of its existence (Gumbricht et al., 2017). In contrast, the Llanos de Moxos has the same geological origin as the Pastaza-Marañón basin as a foreland basin to the east of the Andes (Dumont, 1996). However, the climate in this region has a very strong dry season which, in conjunction with the much smaller watershed, means that peat does not form extensively, and indeed the relatively arid climate favours herbaceous, rather than forested, ecosystems (Hess et al., 2015).

\section{Processes and patterns of carbon storage}

Fluvial dynamics are crucial for understanding the variation in peat accumulation and forest composition within the Pastaza-Marañón basin, as the history of river dynamics appears to define the broad distribution of forest types (Fig. 2b). For example, the Rio Ucayali has moved south, and the Rio Marañon to the north, within the Ucamara depression during the Quaternary (Fig. 2b, Dumont, 1996) and the areas that have been influenced by each of these rivers over time have rather different characters. The region of historical influence of the sediment-rich and meandering waters of the Rio Ucayali is dominated by seasonally flooded forests that are only occasionally associated with peat formation (termed 'tahuampa' or 'restinga' in Peru or varzea in the terminology from central Amazonia; Nebel et al., 2001; Junk et al., 2011). In contrast, the area of historical influence of the Rio Marañón is dominated by rivers with low sediment loads and peat-rich palm swamps (‘aguajales'; consistent with 'igapo' in the terminology from central Amazonia; Junk et al., 2011). To the north of the Rio Marañón, the Rio Tigre has followed a relatively stable course over the last few thousand years due to a diversion about 8,000 years ago which isolated this basin from its original Andean headwaters and reduced its flow (Bernal et al., 2011a). This stability has led to this basin being associated with the deepest peat deposits and 'varillal hidromorfico' vegetation; in contrast, the constantly shifting Rio Pastaza to the west has created one of the largest inland alluvial fans in the world, and is associated with abundant open peatlands (Draper et al., 2014). Undoubtedly, any change in river dynamics, resulting from a greater frequency of high river discharge events related to climate change (Gloor et al., 2015) or direct or indirect efforts by people to alter the course and flow of these rivers, may alter the distribution of vegetation types, the resources associated with them and the capacity of the peatlands to accumulate carbon. 
Figure 2
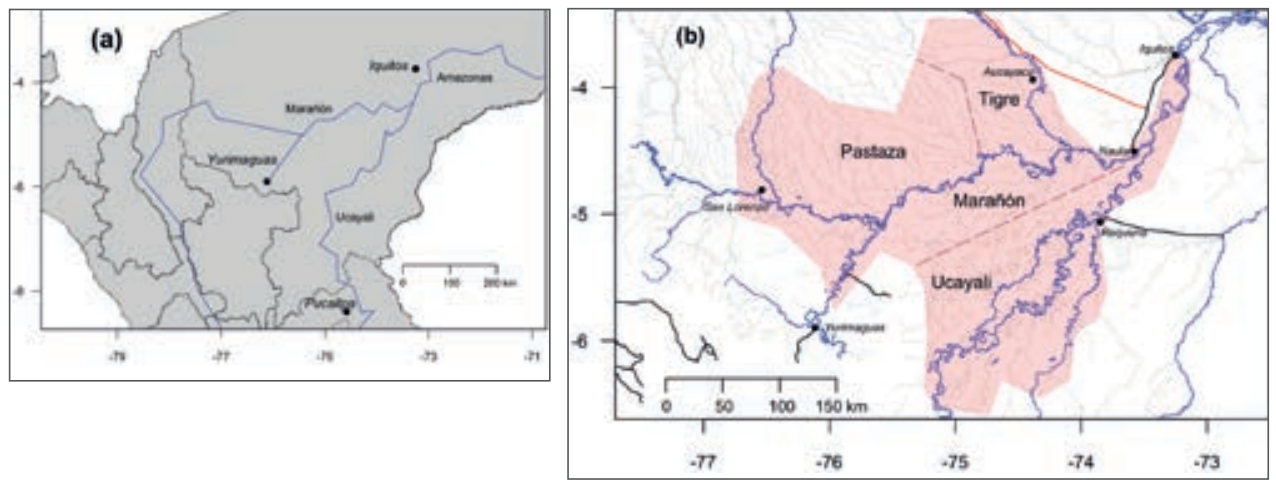

Figure 2. (a) Schematic map of the location of the main rivers and cities to be connected via the hidrovía in northern Peruvian Amazonia; (b) the four principal rivers of the Pastaza-Marañón basin showing their estimated area of historical influence (see text for more detail). Route of proposed road alongside the Rio Tigre and location of the oldest continuous peat deposits discovered to date at Aucayacu also shown.

In terms of floristic composition, succession, dispersal and quite simply, time, are also important factors that underlie the patterns that we see today (Draper et al., 2018). For example, the young age of many of the formations that we see today and the patchiness of tree species distributions suggests that dispersal limitation - the chance arrival of particular taxa as a new landscape develops - determines many of the compositional patterns that we see today (Draper et al., 2018). These processes contrast strongly with typical explanations for species diversity in old growth tropical forests, that focus on, for example, identifying niche differences, in terms of soil preferences (Phillips et al., 2003), light requirements (Whitmore, 1989), or susceptibility to pathogens (Bell et al., 2006) that assume that ecosystems are at equilibrium. In general, successional patterns related to fluvial dynamics are a major driver of variation in vegetation types within the wetlands of the Pastaza-Marañón basin (Kalliola et al., 1991). Although there is agreement that open peatlands represent an early successional stage, and ombrotrophic peatland pole forests are an end point (Kelly et al., 2017), understanding the full range of successional processes within these landscapes remains an important challenge. Palaeoecological studies of the past two thousand years of vegetation change at the present-day palm swamp at Quistococha (Roucoux et al., 2013) and at an ombrotrophic pole forest at San Jorge demonstrate very rapid changes in composition likely related to sites becoming isolated, or connected to, the main river channels (Roucoux et al., 2013; Kelly et al., 2017). In any given location, a palm swamp, for example, can develop - or disappear - in just a few decades as the flooding regime alters. The potential for very rapid change is relevant today for considering the potential impact of climate 
change: the resources that people currently use could disappear or shift in space very quickly. For example, extreme drought and floods cause immediate reductions in the populations of animals that depend on the wetter, or drier, parts of the landscape respectively, with immediate impacts on livelihoods (Bodmer et al., 2018).

\section{The human history of the wetlands}

Given the initial stimulus for studying the wetlands of the Pastaza-Marañón basin, most research to date in this region has focussed on their ecology. However, multidisciplinary work is also now exploring the rich human history and understanding of these ecosystems by indigenous communities. In general terms, it is highly likely that people were living in, and using the resources from, the different Amazonian upland and wetland habitats of the Amazon, shortly after their arrival in South America about 11,200 years ago. One of the emblematic species of these peatlands - Mauritia flexuosa - has a pollen record that stretches back to the Miocene (Rull, 1998) and the use of fruits from a range of species of palm tree has been documented from the earliest sites of human occupation. For example, remains of Attalea microcarpa, Astrocaryum vulgare and Attalea spectabilis dating from 10,000 BP were found at the Pedra Pintada cave at Monte Alegre, Brazil (Roosevelt et al., 1996), which suggests that the use of Mauritia was likely from a similarly early period. The relationships that have developed between people and these wetlands are therefore potentially strong and deep. For example, the Urarina have developed a specific terminology to describe the different peatland ecosystems which demonstrates detailed knowledge about their dynamics and biology and points to the cultural significance of the peatlands (Martín et al. 2019, Schulz et al., 2019b); they also use the fibres from the young leaves of aguaje (Mauritia flexuosa) palms to make traditional textiles - a technique which has recently been declared as Patrimonio Cultural de la Naciòn (Resolución Viceministerial Nº 115-2019-VMPCIC-MC; Martín et al. 2019).

There is also evidence that the occupation of these ecosystems over thousands of years was not associated with extensive ecological disruption. For example, abundant pottery, charcoal and even remains of maize (Zea mays) demonstrate that people inhabited the terraces above the lake and peatland of Quistococha from at least 2500 years ago (Rivas Panduro, 2006; Rivas et al., 2006). However, the pollen from the nearby lake indicate that despite the presence of charcoal during the period of human occupation and therefore presumed use of fire by these people, there was no increase in pioneer tree species typical of disturbed habitats until the period of the expansion of the city of Iquitos over the last two hundred years (Kelly et al., 2018). In part, this is likely due to the existence of a series of social and cultural controls, based on a shared values, beliefs and cultural practices, that today promotes sustainable use of these ecosystems (Martín et al., 2019). In particular, the presence of spiritual beings - 'dwarfs' or 'madres' of the natural world - establishes a relationship of profound respect between people and their environment that goes much 
further than just resource use. The existence of, for example, the baainu, the protector of the palm swamps, that lives in the wetlands of the territories of the Urarina community in the mid- and lower Rio Chambira, instils fear and respect, and without doubt, favours the conservation of these ecosystems (Schulz et al., 2019b).

\section{The conservation challenge today}

The low impact of indigenous groups on the wetlands of the Pastaza-Marañón basin, and more recently, the lack of any road connection between Iquitos and the national road network has led to this region containing one of the largest areas of remaining intact forest on the planet (Watson et al., 2018). This status is however threatened and the future of these forests relies on us addressing how substantial areas of intact tropical forest can be sustained over coming decades, whilst also supporting the livelihoods of the people who live there. The challenge is perhaps three-fold: to work with communities across the basin to manage the long-standing damage caused by oil exploitation, to develop markets for sustainable resources based on biodiversity such as palm fruits, and to find ways to ensure any infrastructure development leads to minimal deforestation.

The extensive oil reserves in this region, which have been exploited since the 1970s in the northern part of the basin (Martínez et al., 2007), present the greatest chronic threat to the health of the indigenous people, wildlife and water of the Pastaza-Marañón basin and beyond. Shocking levels of oil pollution occur both as the result of leaks in the North Peruvian oil pipeline, which stretches as narrow scar across the basin, and as a result of the release of water used in the production of oil. For example, a 2005 study by the Peruvian Ministry of Health, found that World Health Organisation limits for lead were exceeded in $66 \%$ of the blood samples from 74 indigenous children from six native Achuar communities; amongst adults, $99 \%$ of samples exceeded permissible limits for cadmium (Martínez et al., 2007). In a meta-analysis of 194 analyses of the concentration of cadmium in river water samples from the Corrientes, Tigre, Pastaza and Marañón rivers, 19\% exceeded Peruvian limits for drinking water (Yusta-García et al., 2017). The presence of hydrocarbons derived from oil production has also been detected in soils in oil production areas, with likely but unknown impacts on the health of local fauna which consume the soil (Orta-Martínez et al., 2018; Rosell-Melé et al., 2018). The direct and indirect economic benefits to communities of petroleum extraction, through jobs, including payments for participating in clean-up operations and providing services including bushmeat to company workers, need to be viewed in the context of the health implications of long-term and repeated release of hydrocarbons into the environment, and the chronic disruption to these societies (Martínez et al., 2007; Zárate, 2018). At the very least, the conservation challenge is to ensure that information about the health and environmental impacts is available to communities in a timely fashion, to support and strengthen the government bodies responsible for environmental monitoring 
and to pressure both the companies and government bodies to ensure the oil extraction practices and pipeline infrastructure are adequate to eliminate pollution.

In terms of infrastructure development, the fundamental significance of the wetlands of the Pastaza-Marañón basin for conservation and development is that this region lies directly between the city of Iquitos, with a population approaching half a million people (INEI 2018), and the rest of Peru. Any infrastructure connection, whether by road or river, between the city and the rest of the country depends on traversing the wetlands: current plans including linking Iquitos to transport networks by river (via the Rio Marañón and Rio Ucayali to Yurimaguas and Pucallpa respectively; Fig. 2a) and road (alongside the Rio Tigre; Fig. 2a y b). The proposed Hidrovía Amazónica aims to allow shorter journey times and increase river transport among regional hubs along the main tributaries of the Rio Amazonas - the Marañón, Ucayali and Huallaga rivers - by regular dredging of the shallowest reaches (Fig. 2a y b). Such dredging activities are employed across the world (e.g. on the Parana river in Argentina; Paarlberg et al., 2015) as one of a suite of methods to maintain a minimum depth along navigable waterways, even though the high cost and large, negative environmental impact on the biology of the rivers, including fish populations and riverine vegetation is well established (Darby \& Thorne, 1995). Indeed, even disregarding the environmental costs, simply the high economic cost of dredging provides a strong incentive to evaluate carefully how to perform any operation, in terms of, for example, where to place dredged sediments, in order to minimise the requirement for repeated dredging over time and to ensure that the proposed benefits for transport will be realised (Paarlberg et al., 2015; van Vuren et al., 2015). For the adjacent wetlands in the Pastaza Maranon basin, the key question for the proposed dredging is whether it would deepen the channels sufficiently to increase drainage and reduce flooding of the surrounding wetland landscape, as the maintenance of permanent waterlogging is crucial for peat formation. Both of these kinds of hydrological change - lower water table depths and a reduced depth and duration of flooding on adjacent land have been documented in stretches of rivers where sediment mining has taken place (Rinaldi et al., 2005), but it is unclear whether the scale of dredging proposed for the hidrovía would be sufficient to have similar impacts on the wetlands of the Pastaza-Marañón basin. Clearly, a careful evaluation of the environmental impacts of this scheme on the adjacent wetlands is required.

The planned Iquitos - Saramiriza road presents different challenges. The proposed route would connect Iquitos to the national road network via a new road along the east bank of the Rio Tigre which would connect with existing access roads used by oil companies close to the Peru-Ecuador border. Although the route itself is beyond the border of the Ramsar-designated protected area of the Pastaza-Marañón basin, the main problem for the wetlands is that it passes close to the deepest and most ancient peat deposits known in the entire basin (Fig. 2, Roucoux et al., 2017). Here, at site known as Aucayacu, there are seven metres of peat, 
which date back over 8,000 years (Lähteenoja et al., 2012). Road building can have negative local effects on wetland hydrology, but the bigger risk is that improved access could very easily open up the region to colonization and more intensive economic exploitation (e.g. collection of Mauritia fruits, which often entails felling entire trees). Numerous examples exist of new roads leading to increased rates of deforestation and environmental degradation in intact tropical forest settings (Laurance et al., 2009), including following the paving of the InterOceanica highway in southern Peru (Asner et al., 2010). In the case of the peatlands around the Rio Tigre, any disruption is likely to jeopardize their record-breaking below-ground carbon stocks and potentially generate nationally significant carbon emissions. Again, careful evaluation of the potential environmental impacts is required and plans need to be developed to mitigate these threats.

Despite these threats, the wetlands of the Pastaza-Marañón basin have two strong advantages for conservation: their high carbon stocks and the economic importance of non-timber products (Roucoux et al., 2017). The conservation challenge here is to ensure that these opportunities are fully realised to the benefit of local communities. Although the value of the high carbon stocks of peatlands is not consistently recognised in national environmental policies in Peru (Lilleskov et al., 2019), emphasising the carbon stocks of these areas is emerging as an important way to justify and achieve investment in conservation and sustainable management. For example, the Peruvian Fund for Nature Conservation (PROFONANPE) successfully obtained $\$ 6$ million for sustainable management of the palm swamps of Datem de Marañón province from the Green Climate Fund based on the protection of the belowground carbon stocks demonstrated by Draper et al. (2014). Similarly, the justification for the creation of the Yaguas National Park, which attracted a $\$ 1$ million investment by the Andes Amazon Fund, was partly based on the carbon stocks in the wetlands in this area. Developing carbon-based conservation is therefore a proven route to achieving conservation goals in this region and could be expanded (Roucoux et al., 2017).

The high importance of the wetlands for supplying non-timber forest products to communities is another opportunity for conservation. These ecosystems supply construction materials, timber, wood for charcoal, textiles, as well as meat in the form of caiman, peccaries and fish (Bodmer et al., 2018; Schulz et al., 2019a). However, in terms of potentially sustainable resources, their most important asset is palm fruits, notably from aguaje palms, which are harvested on a large scale and sold to local and regional markets (Horn et al., 2018; Schulz et al., 2019a). The presence of such an economically important species is unique among tropical peatlands globally. The opportunity for conservation is therefore clear: frankly, if it is not possible to conserve, derive economic benefits from and sustainably manage natural near-monodominant stands of such a productive and valued tropical tree species as the Mauritia palm, then there is truly little hope for conserving intact tropical forest. The conservation of these wetlands therefore represents an emblem- 
atic example of the wider project in conservation to find ways to leverage the value of biodiversity to support sustainable development (Nobre et al., 2016).

Developing a positive vision of what conservation success would look like for the Pastaza Marañón basin based on palm fruit harvesting, might most usefully draw on the development of the market for açai fruit from the palm Euterpe precatoria in Brazil. Similar to Mauritia, E. precatoria can grow in largely monodominant stands, particularly in the forests surrounding the estuary of the Amazon in eastern Pará state, Brazil (Brondízio et al., 2002). Over recent years, açai fruit production has underpinned the development of businesses worth millions of dollars (Nobre et al., 2016) and can provide a substantial income to communities: it contributes around $60 \%$ of household income from agricultural products in eastern Pará (Brondízio et al., 2002), and, even where less abundant in an upland forest setting, an average of $17 \%$ of household incomes in communities in extractive reserves in Acre (Lopes et al., 2019).

The management of açai presents perhaps three lessons for developing fruit harvesting of Mauritia flexuosa. Firstly, an increasing national and international market for the fruit, driven by an increasing market in expanding Brazilian cities as well as its emergence as an international 'fashion food' from the 1990s on the basis of its properties as an antioxidant, has driven the increase in demand for this product (Brondízio et al., 2002). In comparison, Mauritia fruit remains an important regional product within Amazonian Peru, but both national and international markets need to be developed further if the economic potential of this fruit is to be realised. The interest of the Peruvian drinks company AJE, in using aguaje fruit in its Bio range of drinks could be a significant development. Secondly, açai production demonstrates that the use sustainable harvesting techniques is crucial. Açai harvesting is simpler than fruit harvesting for Mauritia flexuosa, because of the lower fruit height, thinner stems and presence of the fruit below the leaf bases of the palm. In contrast, Mauritia flexuosa fruits are typically harvested by cutting down the female trees which produce fruit, which has led to substantial degradation of the resource base (Baker et al., 2010; van Lent et al. 2018). Projects that promote tree climbing to harvest aguaje fruits are clearly crucial, and the workshops organised by the fruit processing company Recursos Amazónicos Forestales SAC (RAFSAC), IIAP, the Peruvian Protected Areas Authority (SERNANP), and the Peruvian Forest Service (SERFOR) are clearly an important step forward, but must be implemented as long-term, sustained support and need to be expanded to more communities. Finally, the large market for açai in Brazil, has led to the widespread implemention of agroforestry techniques to promote production. For example, weeding natural stands can lead to increase in density of açai from $<20 \%$ to $90 \%$ of stems in eastern Para (Brondízio et al., 2002). In terms of management, increasing the density of Mauritia is not such an important issue, as this species reaches very high densities under natural conditions (Honorio-Coronado et al., 2015). However, such techniques may be valuable to restore degraded stands where the female trees have 
been removed; in stands of $M$. flexuosa in eastern Brazil, careful management has produced stands that have seven female trees for each male individual, greatly increasing production compared to natural stands with equal numbers of male and female trees (Bernal et al., 2011b).

The açai market also illustrates some of the issues which will likely emerge as the market expands, including the importance of maximising community benefit by their involvement in the transformation process of the fruit subsequent to harvesting and maintaining an appropriate balance of costs between the communities and companies who transport the fruit to market (Brondízio et al., 2002). The proposal and maintenance of long-term, constant contracted prices with communities by RAFSAC and SERNANP to ensure a consistent income and commitment to sustainable harvesting is an important step to address these issues. Ensuring market expansion is associated with the development of efficient and effective monitoring techniques and understanding of the social and ecological implications will also be important.

In conclusion, despite the challenges, the optimistic message from the wetlands of the Pastaza Marañón basin, is that there is a realistic opportunity for fostering sustainable management that benefits local and indigenous communities, the regional and national economy, and also protects intact forests. The recent recognition of the carbon stocks of this region allied with the unique economic importance of the biodiversity of this region, is a powerful impetus to support and fund sustainable management. Moreover, the location of the aguajales in the centre of one of the world's last remaining areas of intact tropical forest, means that implementing these solutions has wide conservation relevance. The prize - preserving one of the most diverse, carbon-rich tropical forest landscapes on the planet over the coming decades - should inspire us to address the different facets of this challenge.

\section{Acknowledgements}

We thank Jorge Abad, Freddie Draper, Luis Freitas, Kalle Ruokolainen, Mark Smith and Hanna Tuomisto for very helpful discussions about the issues raised in this chapter. We also acknowledge financial support for research projects that have helped to increase our knowledge of the wetlands of the Pastaza-Marañón basin from NERC (grant NE/R000751/1), the UK Department for Business, Energy and Industrial Strategy and CONCYTEC (Newton Fund Institutional Links programme grant 414694929, delivered by the British Council), the Leverhulme Trust and the Gordon and Betty Moore Foundation (grant 5349). This chapter is a product of the Tropical Wetlands Consortium (https://tropicalwetlands.wp.st-andrews.ac.uk/ en/about/). 


\section{BIBLIOGRAPHY}

ASNER, G.P., Powell, G.V., Mascaro, J., Knapp, D.E., Clark, J.K., Jacobson, J., Kennedy-Bowdoin, T., Balaji, A., Paez-Acosta, G. \& Victoria, E. (2010). High-resolution forest carbon stocks and emissions in the Amazon. Proceedings of the National Academy of Sciences, 107, 16738-16742.

ASNER, G.P., Knapp, D.E., Martin, R.E., Tupayachi, R., Anderson, C.B., Mascaro, J., Sinca, F., Chadwick, K.D., Higgins, M. \& Farfan, W. (2014). Targeted carbon conservation at national scales with high-resolution monitoring. Proceedings of the National Academy of Sciences, 111, E5016-E5022.

BAKER, T.R., Jones, J.P.G., Rendón Thompson, O.R., Román Cuesta, R.M., del Castillo, D., Chan Aguilar, I., Torres, J. \& Healey, J.R. (2010). How can ecologists help realise the potential of payments for carbon in tropical forest countries? Journal of Applied Ecology, 47, 1159-1165.

BAKER, T.R., Phillips, O.L., Malhi, Y., Almeida, S., Arroyo, L., Di Fiore, A., Erwin, T., Killeen, T.J., Laurance, S.G., Laurance, W.F., Lewis, S.L., Lloyd, J., Monteagudo, A., Neill, D.A., Patino, S., Pitman, N.C.A., Silva, J.N.M. \& Martinez, R.V. (2004a). Variation in wood density determines spatial patterns in Amazonian forest biomass. Global Change Biology, 10, 545-562.

BAKER, T.R., Phillips, O.L., Malhi, Y., Almeida, S., Arroyo, L., Di Fiore, A., Erwin, T., Higuchi, N., Killeen, T.J., Laurance, S.G., Laurance, W.F., Lewis, S.L., Monteagudo, A., Neill, D.A., Vargas, P.N., Pitman, N.C.A., Silva, J.N.M. \& Martinez, R.V. (2004b). Increasing biomass in Amazonian forest plots. Philosophical Transactions of the Royal Society of London Series B-Biological Sciences, 359, 353-365.

BEAUMONT, C. (1981). Foreland basins. Geophysical Journal International, 65, 291-329.

BELL, T., Freckleton, R.P. \& Lewis, O.T. (2006). Plant pathogens drive density-dependent seedling mortality in a tropical tree. Ecology Letters, 9, 569-574.

BERNAl, C., Christophoul, F., Darrozes, J., Soula, J.-C., Baby, P. \& Burgos, J. (2011a) Late Glacial and Holocene avulsions of the Rio Pastaza Megafan (Ecuador-Peru): frequency. and controlling factors. International Journal of Earth Sciences, 100, 1759-1782.

BERNAL, R., Torres, C., García, N., Isaza, C., Navarro, J., Vallejo, M.I., Galeano, G. \& Balslev, H. (2011b). Palm management in south america. The Botanical Review, 77, 607-646.

BODMER, R., Mayor, P., Antunez, M., Chota, K., Fang, T., Puertas, P., Pittet, M., Kirkland, M., Walkey, M. \& Rios, C. (2018) Major shifts in Amazon wildlife populations from recent intensification of floods and drought. Conservation Biology, 32, 333-344.

BRONDÍZIO, E.S., Safar, C.A. \& Siqueira, A.D. (2002). The urban market of açaí fruit (Euterpe oleracea Mart.) and rural land use change: ethnographic insights into the role of price and land tenure constraining agricultural choices in the Amazon estuary. Urban Ecosystems, 6, 67-97.

DARBY, S.E. \& Thorne, C.R. (1995). Fluvial maintenance operations in managed alluvial rivers. Aquatic Conservation: Marine and Freshwater Ecosystems, 5, 37-54.

DARGIE, G.C., Lewis, S.L., Lawson, I.T., Mitchard, E.T., Page, S.E., Bocko, Y.E. \& Ifo, S.A. (2017). Age, extent and carbon storage of the central Congo Basin peatland complex. $\mathrm{Na}$ ture, 542, 86.

DECELLES, P.G. \& Giles, K.A. (1996). Foreland basin systems. Basin Research, 8, 105-123.

DRAPER, F.C., Roucoux, K.H., Lawson, I.T., Mitchard, E.T., Coronado, E.N.H., Lähteenoja, O., Montenegro, L.T., Sandoval, E.V., Zaráte, R. \& Baker, T.R. (2014). The distribution and 
amount of carbon in the largest peatland complex in Amazonia. Environmental Research Letters, 9, 124017.

DRAPER, F.C., Honorio Coronado, E.N., Roucoux, K.H., Lawson, I.T., Pitman, N.C.A., Fine, P.V.A., Phillips, O.L., Torres Montenegro, L.A., Valderrama Sandoval, E., Mesones, I., García-Villacorta, R., Ramirez Arévalo, F.R. \& Baker, T.R. (2018). Peatland forests are the least diverse tree communities documented in Amazonia, but contribute to high regional beta-diversity. Ecography, 41, 1256-1269.

DUMONT, J.-F. (1996). Neotectonics of the Subandes-Brazilian craton boundary using geomorphological data: the Marañon and Beni basins. Tectonophysics, 259, 137-151.

DUMONT, J.-F. \& Fournier, M. (1994). Geodynamic environment of Quaternary morphostructures of the subandean foreland basins of Peru and Bolivia: characteristics and study methods. Quaternary International, 21, 129-142.

ENCARNACIÓN, F. (1985). Introduction a la flora y vegetacion de la Amazonia peruana: estado actual de los estudios, medio natural y ensayo de una clave de determinacion de las formaciones vegetales en la llanura amazonica. Candollea, 40, 237-252.

FINE, P.V.A., Daly, D.C., Munoz, G.V., Mesones, I. \& Cameron, K.M. (2005). The contribution of edaphic heterogeneity to the evolution and diversity of Burseraceae trees in the western Amazon. Evolution, 59, 1464-1478.

FREITAS, L., Otárola, E., Del Castillo, D., Linares, C., Martínez, P. \& Malca, D. (2006). Servicios ambientales de almacenamiento y secuestro de carbono del ecosistema aguajal en la Reserva Nacional Pacaya Samiria, Loreto-Perú. In: IIAP Documento Técnico, p. 62

GENTRY, A.H. (1988). Tree species richness of upper Amazonian forests. Proceedings of the National Academy of Sciences, USA, 85, 156-159.

GLOOR, M., Barichivich, J., Ziv, G., Brienen, R., Schöngart, J., Peylin, P., Cintra, L., Barcante, B., Feldpausch, T. \& Phillips, O. (2015) Recent Amazon climate as background for possible ongoing and future changes of Amazon humid forests. Global Biogeochemical Cycles, 29, 1384-1399.

GUMBRICHT, T., Roman-Cuesta, R.M., Verchot, L., Herold, M., Wittmann, F., Householder, E., Herold, N. \& Murdiyarso, D. (2017). An expert system model for mapping tropical wetlands and peatlands reveals South America as the largest contributor. Global Change Biology, 23, 3581-3599.

GUZMÁN, W. (2004). Valoración económica de beneficios ambientales en el manejo sostenible de humedales: Estudio del caso del manejo sostenible de sistemas de 'Aguajal' en la comunidad de Parinari, Reserva Nacional Pacaya Samiria (RNPS). En: Valoración económica de los bienes y servicios ambientales: Resultados del segundo programa de becas 2002-2003. R. Loyola Gonzáles y E. García Zamora (editores). INRENA-USAID. Lima-Perú. 269-302.

HESS, L.L., Melack, J.M., Affonso, A.G., Barbosa, C., Gastil-Buhl, M. \& Novo, E.M. (2015). Wetlands of the lowland Amazon basin: Extent, vegetative cover, and dual-season inundated area as mapped with JERS-1 synthetic aperture radar. Wetlands, 35, 745-756.

HONORIO-CORONADO, E.N., Vega-Arenas, J.E. \& Corrales-Medina, M.N. (2015). Diversidad, estructura y carbono de los bosques aluviales del noreste peruano. Folia Amazónica, 24, 55-70.

HORN, C.M., Paredes, V.H.V., Gilmore, M.P. \& Endress, B.A. (2018). Spatio-temporal patterns of Mauritia flexuosa fruit extraction in the Peruvian Amazon: Implications for conservation and sustainability. Applied Geography, 97, 98-108. 
INEI (2018). Perú: Perfil Sociodemográfico, Informe Nacional, Censos Nacionales 2017, Instituto Nacional de Estadística e Informática, Lima, Perú.

JOHNSON, M.O., Galbraith, D., Gloor, M., De Deurwaerder, H., Guimberteau, M., Rammig, A., Thonicke, K., Verbeeck, H., Randow, C., Monteagudo, A., Phillips, O.L., Brienen, R.J.W., Feldpausch, T.R., G., L.G., Fauset, S., Quesada, C.A., Christoffersen, B., Ciais, P., Gilvan, S., Kruijt, B., Meir, P., Moorcroft, P., Zhang, K., Alvarez, E., Alves de Oliveira, A., Amaral, I., Andrade, A., L.E.O.C., A., Araujo-Murakami, A., Arets, E.J.M.M., Arroyo, L., Aymard, G.A., Baraloto, C., Barroso, J., Bonal, D., Boot, R., Camargo, J., Chave, J., Cogollo, A., Cornejo Valverde, F., da Costa, L., di Fiore, A., Ferreira, L., Higuchi, N., Honorio, E., Killeen, T.J., Laurance, W.G., Laurance, S.F., Licona, J., Lovejoy, T., Malhi, Y., Marimon, B., Marimon Junior, B.H., Matos, D.C.L., Mendoza, C., Neill, D.A., Pardo, G., Peña-Claros, M., Pitman, N.C.A., Poorter, L., Prieto, A., Ramirez-Angulo, H., Roopsind, A., Rudas, A., Salomao, R.P., Silveira, M., Stropp, J., ter Steege, H., Terborgh, J., Thomas, R., Toledo, M., Torres, A., van der Heijden, G.M.F., Vasquez, R., Vieira, I., Vilanova, E., Vos, V.A. \& Baker, T.R. (2016). Variation in stem mortality rates determines patterns of aboveground biomass in Amazonian forests: implications for dynamic global vegetation models. Global Change Biology, 22, 3996-4013.

JUNK, W.J., Piedade, M.T.F., Schöngart, J., Cohn-Haft, M., Adeney, J.M. \& Wittmann, F. (2011). A classification of major naturally-occurring Amazonian lowland wetlands. Wetlands, 31, 623-640.

KALLIOLA, R., Puhakka, M., Salo, J., Tuomisto, H. \& Ruokolainen, K. (1991). The dynamics, distribution and classification of swamp vegetation in Peruvian Amazonia. Annales Botanici Fennici, 225-239.

KELLY, T.J., Lawson, I.T., Roucoux, K.H., Baker, T.R., Jones, T.D. \& Sanderson, N.K. (2017). The vegetation history of an Amazonian domed peatland. Palaeogeography, Palaeoclimatology, Palaeoecology, 468, 129-141.

KELLY, T.J., Lawson, I.T., Roucoux, K.H., Baker, T.R., Honorio-Coronado, E.N., Jones, T.D. \& Rivas Panduro, S. (2018). Continuous human presence without extensive reductions in forest cover over the past 2500 years in an aseasonal Amazonian rainforest. Journal of Quaternary Science, 33, 369-379.

LÄHTEENOJA, O., Flores, B. \& Nelson, B. (2013). Tropical peat accumulation in Central Amazonia. Wetlands, 33, 495-503.

LÄHTEENOJA, O., Ruokolainen, K., Schulman, L. \& Alvarez, J. (2009a). Amazonian floodplains harbour minerotrophic and ombrotrophic peatlands. Catena, 79, 140-145.

LÄHTEENOJA, O., Ruokolainen, K., Schulman, L. \& Oinonen, M. (2009b). Amazonian peatlands: an ignored C sink and potential source. Global Change Biology, 15, 2311-2320.

LÄHTEENOJA, O., Reátegui, Y.R., Räsänen, M., Torres, D.D.C., Oinonen, M. \& Page, S. (2012). The large Amazonian peatland carbon sink in the subsiding Pastaza-Marañon foreland basin. Global Change Biology, 18, 164-178.

LAURANCE, W.F., Goosem, M. \& Laurance, S.G. (2009). Impacts of roads and linear clearings on tropical forests. Trends in Ecology E Evolution, 24, 659-669.

LEHTONEN, S. \& Tuomisto, H. (2007). Ecological and genetic notes on Lindsaea digitata (Lindsaeaceae), a new fern species from western Amazonia. Nordic Journal of Botany, 25, 145-151.

van LENT, J., Hergoualc'h, K., Verchot, L., Oenema, O. \& van Groenigen, J.W. (2018). Greenhouse gas emissions along a peat swamp forest degradation gradient in the Peruvian Amazon: soil moisture and palm roots effects. Mitigation and Adaptation Strategies for Global Change, 24, 625-643. 
LILLESKOV, E., McCullough, K., Hergoualc'h, K., del Castillo Torres, D., Chimner, R., Murdiyarso, D., Kolka, R., Bourgeau-Chavez, L., Hribljan, J. \& del Aguila Pasquel, J. (2019). Is Indonesian peatland loss a cautionary tale for Peru? A two-country comparison of the magnitude and causes of tropical peatland degradation. Mitigation and Adaptation Strategies for Global Change, 24, 591-623.

LOPES, E., Soares-Filho, B., Souza, F., Rajão, R., Merry, F. \& Ribeiro, S.C. (2019). Mapping the socio-ecology of Non Timber Forest Products (NTFP) extraction in the Brazilian Amazon: The case of açaí (Euterpe precatoria Mart) in Acre. Landscape and Urban Planning, 188, 110-117.

MALHI, Y., Aragao, L.E.O., Metcalfe, D.B., Paiva, R., Quesada, C.A., Almeida, S., Anderson, L., Brando, P., Chambers, J.Q. \& COSTA, D. (2009). Comprehensive assessment of carbon productivity, allocation and storage in three Amazonian forests. Global Change Biology, 15, 1255-1274.

MARTín, M., Núñez, C., Fabiano, E., Del Aguila, M., Schulz, C., Laurie, N., Sanjurjo, J., Davies, A., Roucoux, K., Lawson, I. \& Andueza, L. (2019). Urarina: identidad y memoria en la cuenca del Chambira. IIAP.

MARTÍNEZ, M.O., Napolitano, D.A., MacLennan, G.J., O'Callaghan, C., Ciborowski, S. \& Fabregas, X. (2007). Impacts of petroleum activities for the Achuar people of the Peruvian Amazon: summary of existing evidence and research gaps. Environmental Research Letters, 2, 045006.

MINAM (2016). Tercera Comunicación Nacional del Perú a la Convención Marco de las Naciones Unidas sobre el Cambio Climático. Lima, Peru.

NEBEL, G., Dragsted, J. \& Vegas, A.S. (2001). Litter fall, biomass and net primary production in flood plain forest in the Peruvian Amazon. Forest Ecology and Management, 150, 93-102.

Nobre, C.A., Sampaio, G., Borma, L.S., Castilla-Rubio, J.C., Silva, J.S. \& Cardoso, M. (2016) Land-use and climate change risks in the Amazon and the need of a novel sustainable development paradigm. Proceedings of the National Academy of Sciences, 113, 10759-10768.

Orta-Martínez, M., Rosell-Melé, A., Cartró-Sabaté, M., O'Callaghan-Gordo, C., Moraleda-Cibrián, N. \& Mayor, P. (2018). First evidences of Amazonian wildlife feeding on petroleum-contaminated soils: A new exposure route to petrogenic compounds? Environmental Research, 160, 514-517.

PAARLBERG, A., Guerrero, M., Huthoff, F. \& Re, M. (2015). Optimizing dredge-and-dump activities for river navigability using a hydro-morphodynamic model. Water, 7, 3943-3962. Page, S., Rieley, J. \& Wüst, R. (2006) Lowland tropical peatlands of Southeast Asia. Developments in Earth Surface Processes, 9, 145-172.

PHILLIPS, O.L., Nunez Vargas, P., Monteagudo, A., Pena Cruz, A., Chuspe Zans, M., Sanchez, G., Yli-Halla, M. \& Rose, S. (2003). Habitat association among Amazonian tree species: a landscape-scale approach. Journal of Ecology, 91, 757-775.

QUESADA, C., Lloyd, J., Anderson, L., Fyllas, N., Schwarz, M. \& Czimczik, C. (2011) Soils of Amazonia with particular reference to the RAINFOR sites. Biogeosciences, 8, 1415-1440.

Rinaldi, M., Wyżga, B. \& Surian, N. (2005). Sediment mining in alluvial channels: physical effects and management perspectives. River Research and Applications, 21, 805-828.

RIVAS Panduro, S. (2006). Proyecto de Investigacion: Excavaciones Arqueologicas en Quistococha, Loreto-Amazonia Peruana. In. Instituto Nacional de Cultura del Peru, Lima.

RIVAS, S., Oyuela-Caycedo, A. \& Zimmerman, A. (2006). Informe preliminar sobre los hallazgos en el sitio arqueologico de Quistococha, Amazonia Peruana. In: Bol. Estudios Amazónicos, pp. 79-97. Universidad Nacional Mayor de San Marcos 
ROOSEVELT, A.C., Da Costa, M.L., Machado, C.L., Michab, M., Mercier, N., Valladas, H., Feathers, J., Barnett, W., Da Silveira, M.I. \& Henderson, A. (1996). Paleoindian cave dwellers in the Amazon: the peopling of the Americas. Science, 272, 373-384.

ROSELL-MELÉ, A., Moraleda-Cibrián, N., Cartró-Sabaté, M., Colomer-Ventura, F., Mayor, P. \& Orta-Martínez, M. (2018). Oil pollution in soils and sediments from the Northern Peruvian Amazon. Science of The Total Environment, 610, 1010-1019.

ROUCOUX, K.H., Lawson, I.T., Jones, T.D., Baker, T.R., Coronado, E.H., Gosling, W.D. \& Lähteenoja, O. (2013). Vegetation development in an Amazonian peatland. Palaeogeography, Palaeoclimatology, Palaeoecology, 374, 242-255.

ROUCOUX, K.H., Lawson, I.T., Baker, T.R., Del Castillo Torres, D., Draper, F.C., Lähteenoja, O., Gilmore, M.P., Honorio Coronado, E.N., Kelly, T.J., Mitchard, E.T.A. \& Vriesendorp, C.F. (2017). Threats to intact tropical peatlands and opportunities for their conservation. Conservation Biology, 31, 1283-1292.

RULL, V. (1998). Biogeographical and evolutionary considerations of Mauritia (Arecaceae), based on palynological evidence. Review of Palaeobotany and Palynology, 100, 109-122.

Ruokolainen, K., Schulman, L. \& Tuomisto, H. (2001). On Amazonian peatlands. International Mire Conservation Group Newsletter, 4, 8-10.

SCHULMAN, L., Ruokolainen, K. \& Tuomisto, H. (1999). Parameters for global ecosystem models. Nature, 399, 535.

SCHULZ, C., Martín, M., Pérez, C.N., Villacorta, M.D.A., Laurie, N., Lawson, I.T. \& Roucoux, K.H. (2019a). Uses, cultural significance, and management of peatlands in the Peruvian Amazon: Implications for conservation. Biological Conservation, 235, 189-198.

SCHULZ, C., Martín, M., Núñez Pérez, C., Del Águila Villacorta, M., Laurie, N., Lawson, I.T. \& Roucoux, K.H. (2019b). Peatland and wetland ecosystems in Peruvian Amazonia: indigenous classifications and perspectives. Ecology and Society, 12.

SULlivaN, M., Talbot, J., Lewis, S., Phillips, O., Qie, L., Begne, S., Chave, J., Cuni Sanchez, A., Hubau, W., Lopez-Gonzalez, G., Miles, L., Monteagudo-Mendoza, A., Sonké, B., Sunderland, T., ter Steege, H., White, L., Affum-Baffoe, K., Aiba, S., Almeida, E., Almeida de Oliveira, E., Alvarez-Loayza, P., Álvarez Dávila, E., Andrade, A., Aragão, L., Ashton, P., Aymard, C., Baker, T., Balinga, M., Banin, L., Baraloto, C., Bastin, J.-F., Berry, N., Bogaert, J., Bonal, D., Bongers, F., Brienen, R., Camargo, J., Cerón, C., Chama Moscoso, V., Chezeaux, E., Clark, C., Cogollo Pacheco, A., Comiskey, J., Cornejo Valverde, F., Honorio Coronado, E., Dargie, G., Davies, S., De Canniere, C., Djuikouo, K., Doucet, J.-L., Erwin, T., Espejo, J., Ewango, C., Fauset, S., Feldpausch, T., Herrera, R., Gilpin, M., Gloor, E., Hall, J., Harris, D., Hart, T., Kartawinata, K., Khoon Kho, L., Kitayama, K., Laurance, S., Laurance, W., Leal, M., Lovejoy, T., Lovett, J., Lukasu, F., Makana, J., Malhi, Y., Maracahipes, L., Marimon, B., Marimon, B., Marshall, A., Morandi, P., Mukendi, J., Mukinzi, J., Nilus, R., Núñez Vargas, P., Pallqui Camacho, N., Pardo, G., Peña-Claros, M., Pétronelli, P., Pickavance, G., Poulsen, A., Poulsen, J., Primack, R., Priyadi, H., Quesada, C., Reitsma, J., Réjou-Méchain, M., Restrepo, Z., Rutishauser, E., Salim, K., Salomão, R., Samsoedin, I., Sheil, D., Sierra, R., Silveira, M., Slik, J., Steel, L., Taedoumg, H., Tan, S., Terborgh, J., Thomas, S., Toledo, M., Umunay, P., Valenzuela Gamarra, L., Vieira, I., Vos, V., Wang, O., Willcock, S. \& Zemagho, L. (2017a). Data from Diversity and carbon storage across the tropical forest biome. ForestPlots.net.

SULLIVAN, M.J.P., Talbot, J., Lewis, S.L., Phillips, O.L., Qie, L., Begne, S., Chave, J., Cuni Sanchez, A., Hubau, W., Lopez-Gonzalez, G., Miles, L., Monteagudo-Mendoza, A., Sonké, B., Sunderland, T., ter Steege, H., White, L., Affum-Baffoe, K., Aiba, S., Almeida, E., Almeida de Oliveira, E., Alvarez-Loayza, P., Álvarez Dávila, E., Andrade, A., Aragão, L., Ashton, P., 
Aymard, C., Baker, T., Balinga, M., Banin, L., Baraloto, C., Bastin, J.-F., Berry, N., Bogaert, J., Bonal, D., Bongers, F., Brienen, R., Camargo, J., Cerón, C., Chama Moscoso, V., Chezeaux, E., Clark, C., Cogollo Pacheco, A., Comiskey, J., Cornejo Valverde, F., Honorio Coronado, E., Dargie, G., Davies, S., De Canniere, C., Djuikouo, K., Doucet, J.-L., Erwin, T., Espejo, J., Ewango, C., Fauset, S., Feldpausch, T., Herrera, R., Gilpin, M., Gloor, E., Hall, J., Harris, D., Hart, T., Kartawinata, K., Khoon Kho, L., Kitayama, K., Laurance, S., Laurance, W., Leal, M., Lovejoy, T., Lovett, J., Lukasu, F., Makana, J., Malhi, Y., Maracahipes, L., Marimon, B., Marimon, B., Marshall, A., Morandi, P., Mukendi, J., Mukinzi, J., Nilus, R., Núñez Vargas, P., Pallqui Camacho, N., Pardo, G., Peña-Claros, M., Pétronelli, P., Pickavance, G., Poulsen, A., Poulsen, J., Primack, R., Priyadi, H., Quesada, C., Reitsma, J., Réjou-Méchain, M., Restrepo, Z., Rutishauser, E., Salim, K., Salomão, R., Samsoedin, I., Sheil, D., Sierra, R., Silveira, M., Slik, J., Steel, L., Taedoumg, H., Tan, S., Terborgh, J., Thomas, S., Toledo, M., Umunay, P., Valenzuela Gamarra, L., Vieira, I., Vos, V., Wang, O., Willcock, S. \& Zemagho, L. (2017b). Diversity and carbon storage across the tropical forest biome. Scientific Reports, 39102.

TIAN, H., Melillo, J.M., Kicklighter, D.W., McGuire, A.D., Helfrich, J.V.K., Moore, B. \& Vörösmarty, C.J. (1998). Effect of interannual climate variability on carbon storage in Amazonian ecosystems. Nature, 396, 664-667.

TUOMISTO, H., Ruokolainen, K., Kalliola, R., Linna, A., Danjoy, W. \& Rodriguez, Z. (1995) Dissecting Amazonian Biodiversity. Science, 269, 63-66.

van VUREN, S., Paarlberg, A. \& Havinga, H. (2015). The aftermath of "Room for the River" and restoration works: Coping with excessive maintenance dredging. Journal of Hydro-environment Research, 9, 172-186.

VÁSQUEZ Martínez, R. (1997). Flórula de las Reservas Biologicas de Iquitos, Perú. Missouri Botanic Garden.

WATSON, J.E., Evans, T., Venter, O., Williams, B., Tulloch, A., Stewart, C., Thompson, I., Ray, J.C., Murray, K. \& Salazar, A. (2018). The exceptional value of intact forest ecosystems. Nature Ecology \& Evolution, 2, 599.

WHITMORE, T.C. (1989). Canopy gaps and the two major groups of forest trees. Ecology, 70, 536-538.

YUSTA-GARCÍA, R., Orta-Martínez, M., Mayor, P., González-Crespo, C. \& Rosell-Melé, A. (2017). Water contamination from oil extraction activities in Northern Peruvian Amazonian rivers. Environmental Pollution, 225, 370-380.

ZÁRATE, J. (2018). Guerras del interior. Debate, Lima 


\title{
THE IMPACT OF ROADS ON INDIGENOUS TERRITORIES
}

\author{
Ermeto Tuesta
}

The roads that cross the communities' territories are the main cause of deforestation because not only do they encourage settlers to invade but, in some areas, they result in bad practice by indigenous peoples who rent out their lands to these settlers for cash cropping. This in turn, creates a market dependency among community members.

The following are the main causes of deforestation:

- The construction of national, regional and local roads through often largely forested and protected community lands, with the argument that it helps to get their agricultural goods to market but which, in the long term, ends up encouraging the invasion of settlers, loggers and miners.

- The construction of footpaths, promoted by a district's politicians and mayors with the argument that they are connecting local areas to markets.

- $\quad$ The construction of local bridges that offer access to invaders, tenants and loggers.

- $\quad$ The renting of lands to settlers and businessmen for cash crops.

- The expansion of agroindustrial crops such as oil palm, and illegal crops such as the coca leaf.

- Formal and informal mining.

Peru covers an area of 128 million hectares, of which 73 million ha are natural forest. Two million hectares of Amazonian rainforest were lost over the 20112017 period. (Source: MINAGRI, SERFOR, MINAM, PNCB and OTCA.)

Road construction projects, including national, regional and local, have been of significant importance to Peruvian governments for decades, with the argument that they will improve the cultural, political and economic integration of the coastal, highland and forest regions, and boost national and regional economic development.

Different governments have argued that reliable transport infrastructure will improve regional integration to the benefit of the country's social and economic development. However, the roads that cross through native communities' demarcated and titled territories generally pass through environmentally-sensitive areas and may therefore have significant social and environmental impacts. 


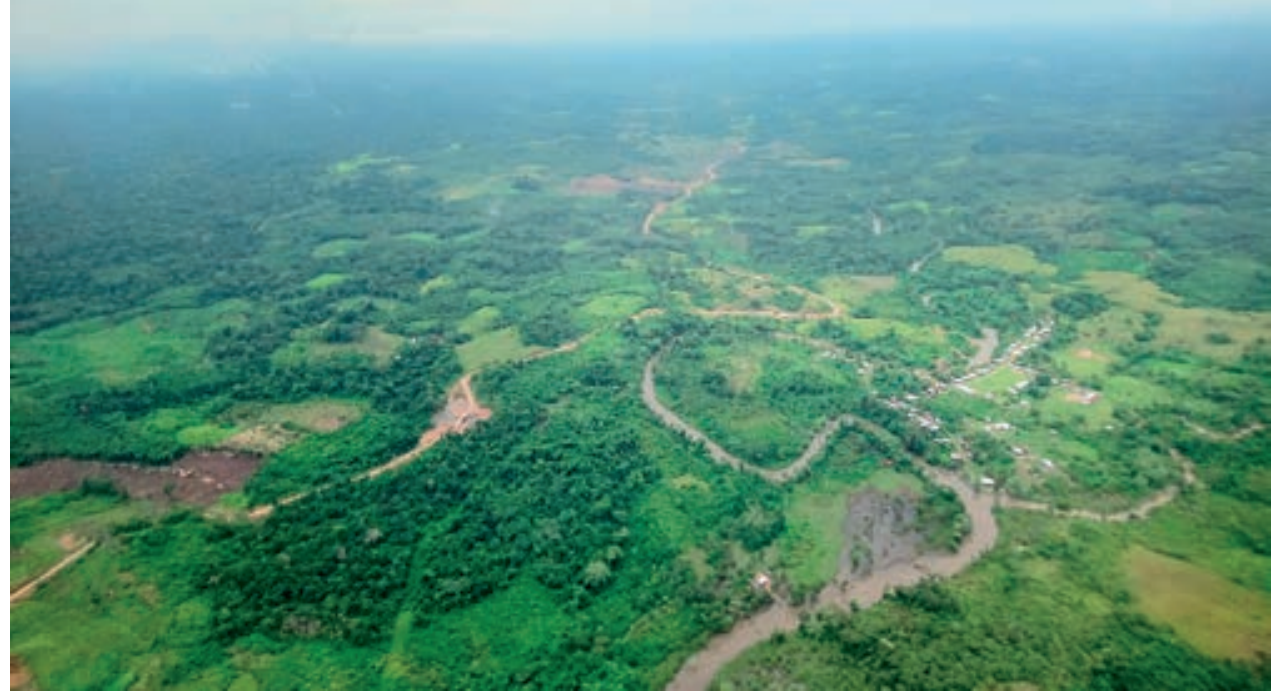

Aerial photo Yurimaguas - San Lorenzo

This article studies the impact of roads crossing indigenous territories in the regions of Amazonas, Loreto, San Martín and Madre de Dios, affecting the demarcated and titled territories of the indigenous Awajún, Shawi, Harakmbut, Ese' Eja, Shipibo-Conibo and Amahuaca peoples.

\section{What happens to the forests, water and other resources?}

The first Law on Native Communities was enacted in 1974, D.L. 20653, and replaced in 1978 by D.L. 22175. Forty-five years later, a large proportion of the indigenous population continue to conserve their forests. In the communities whose territories have been crossed by roads, however, access has been facilitated to settlers, traders and extraction companies and this has resulted in changes in the traditional forms of occupation, exploitation and management of the environment and natural resources. The demarcation and titling of the communities does not guarantee full ownership of their territories because different laws, often in contradiction to each other, are in violation of the rights acquired by indigenous peoples through having lived in the region since before the time of the Peruvian State.

The superimposition of roads on indigenous territories has an impact on the living conditions of these people because their economy becomes dependent on the market and on national society. Most of these territories have ended up with few, if any, preserved areas because the indigenous peoples, excited by the illusion of progress, have rented their lands to settlers to grow cash crops such as rice, coffee, papaya, pineapple, banana and maize, or they have ceded their forests for logging, without having a forest management plan in place. Gold mining, under the system of "inviting" miners to pay the landowner a percentage of their find, is likewise destroying the territories and having negative consequences for indigenous societies. These communities will find it difficult to survive as indigenous peoples in the future because they will have nowhere left to hunt, fish or gather. Resource scarcity will mean that families from communities affected by these processes will have to leave their areas of origin in search of new lands on which to 
survive and create territories for future generations. Such is the case of Awajún community members from Alto Mayo who have had to migrate, creating three new communities in the Ucayali region.

Indigenous peoples are being integrated into the rest of the country on the basis of transient economic opportunities, in order to make the most of infrastructure built by the State through international agreements or by logging, mining and oil companies. The latter attract the younger community members' and authorities' attention with seductive talk of short-term development which, in reality, always ends up creating internal problems between community members. It also creates external problems as neighbouring communities begin to compete for ownership of territories adjacent to the roads, as these are in greatest demand for agricultural crops.

The following map shows the case of Awajún communities settled along the Bagua-Nieva-Saramiriza highway (Amazonas region) who have rented out lands for papaya and pineapple cultivation, thus resulting in an invasion of settlers.

\section{Map 1. Awajún communities in Amazonas}

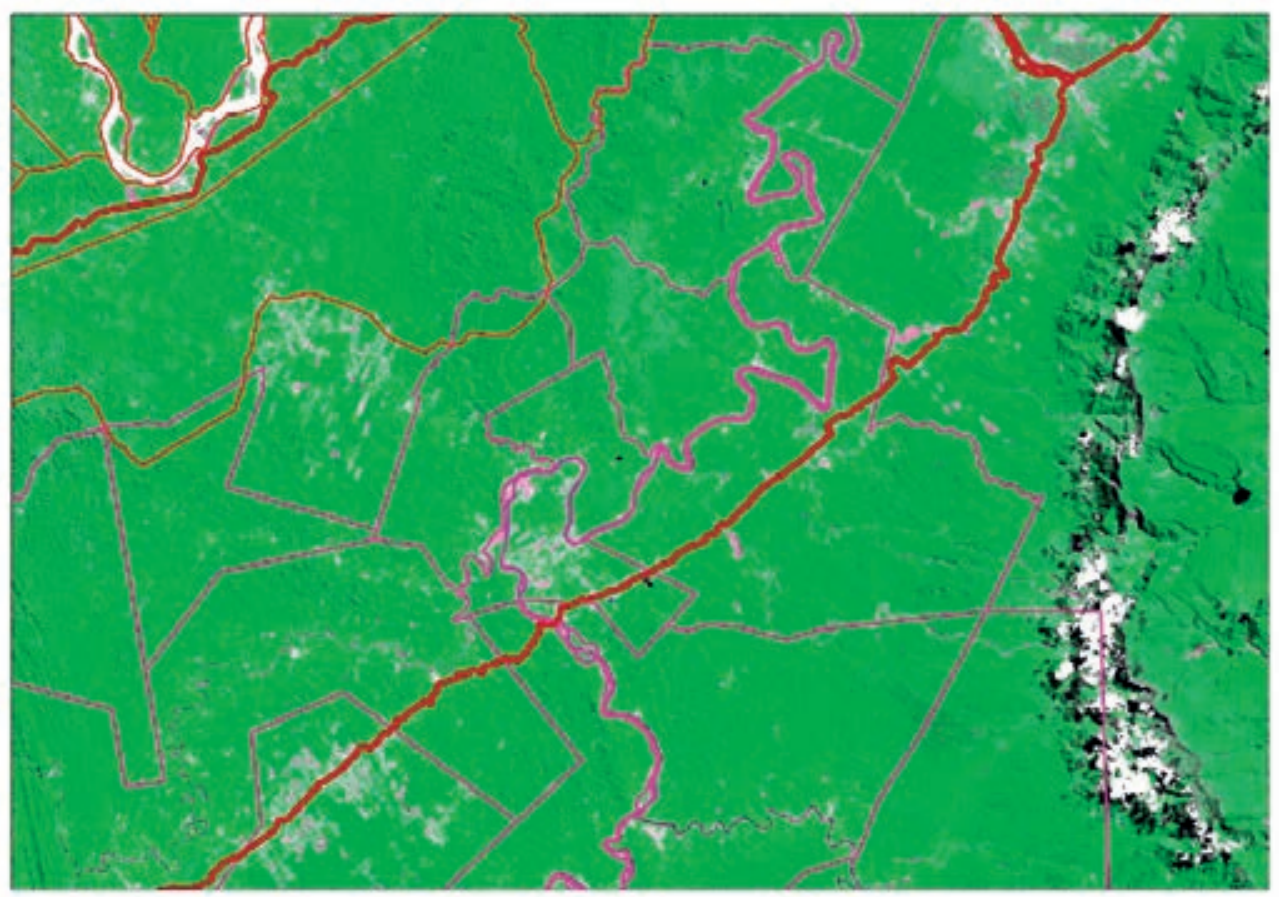

The following map shows the case of Shawi communities located along the Tarapoto-Yurimaguas-Balsapuerto highway (Loreto region), who have rented out lands for rice, coffee, papaya and banana crops, with the resulting settler invasions. 


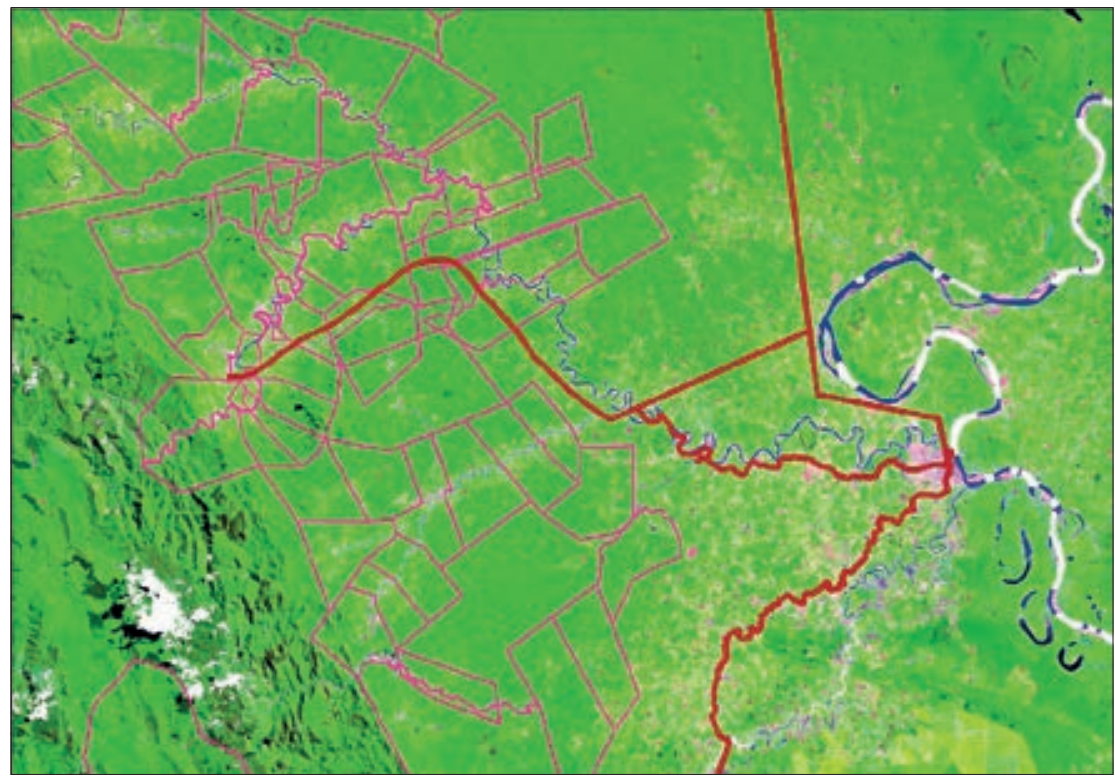

The following two maps show the case of Awajún communities situated along the Alto Mayo highway (San Martín region), who have rented community lands for rice, coffee, papaya and banana crops, resulting in settler invasions.

\section{Map 3. Awajún communities in San Martín}

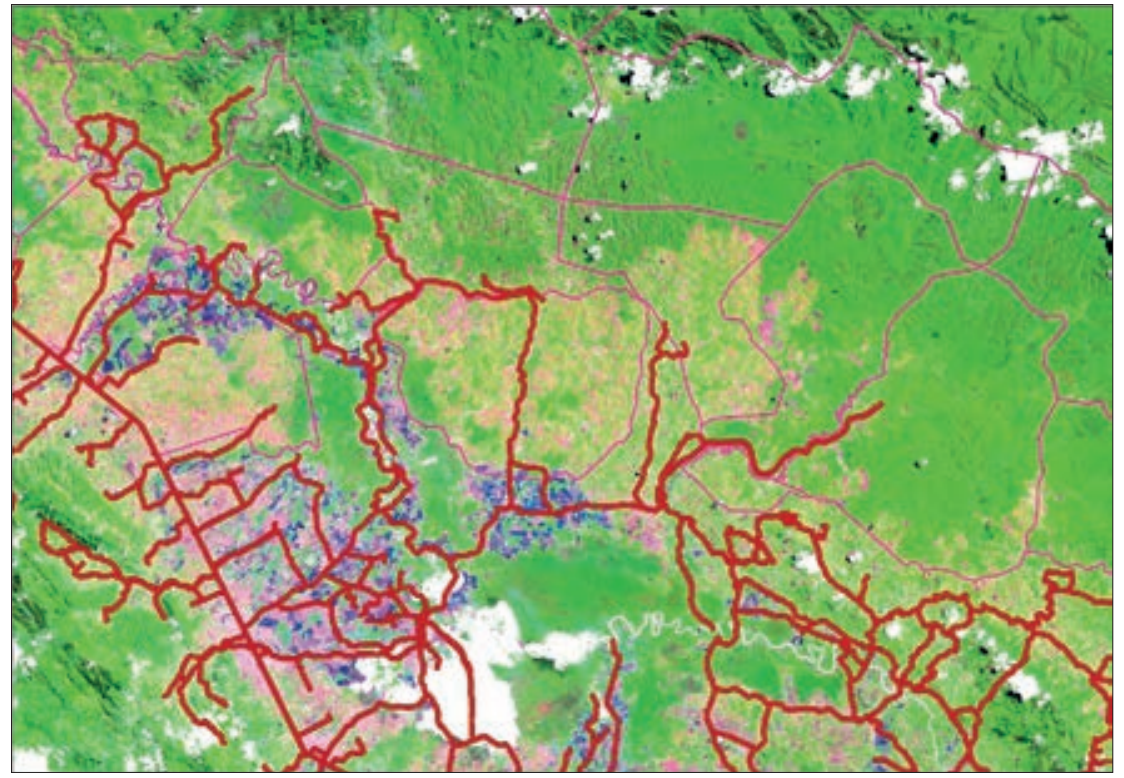




\section{Map 3.1. Awajún communities in San Martín}

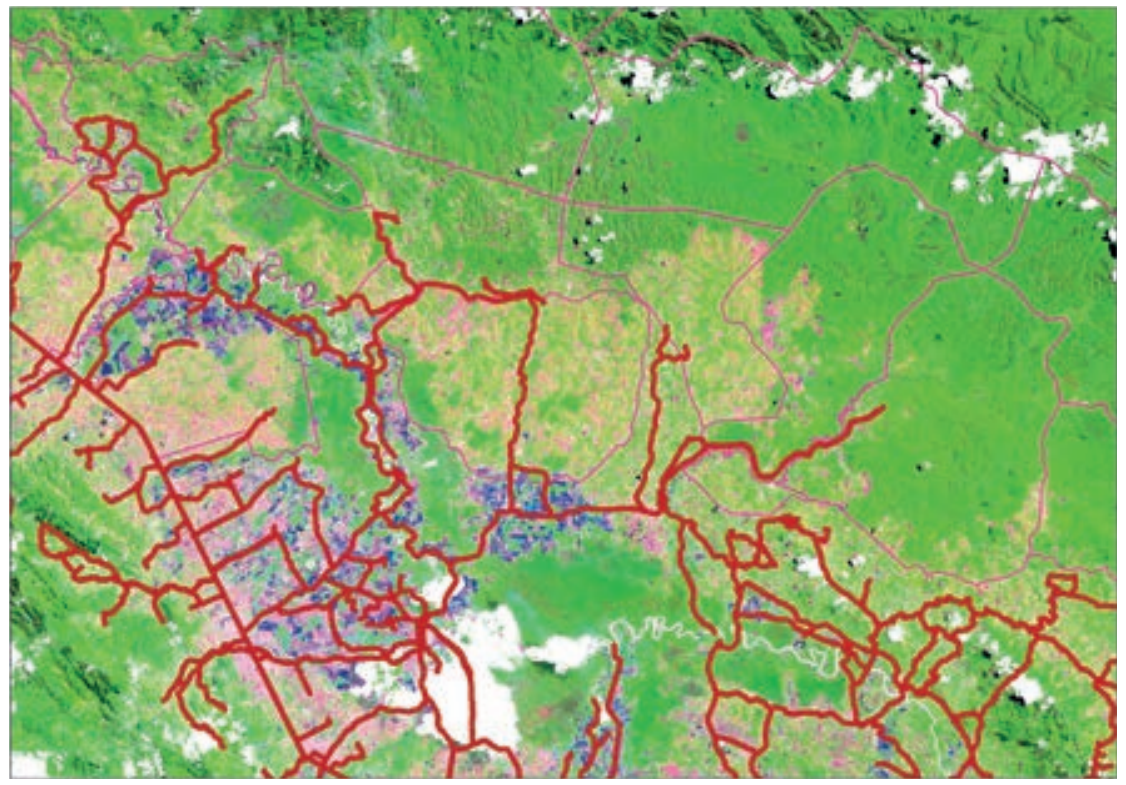

The following maps give a general overview. Map No. 4 gives the case of Harakmbut, Ese Eja, Shipibo-Conibo and Amahuaca indigenous communities along the Interoceánica Sur highway (Madre de Dios region), who have rented out their land for gold mining. The community members "invite" in middlemen who pay them a percentage of the gold they extract from their lands. Both land and forest end up being destroyed by this activity. A large part of the community territories ends up as desert following such goldmining.

\section{Map 4. Communities of different peoples in Madre de Dios}

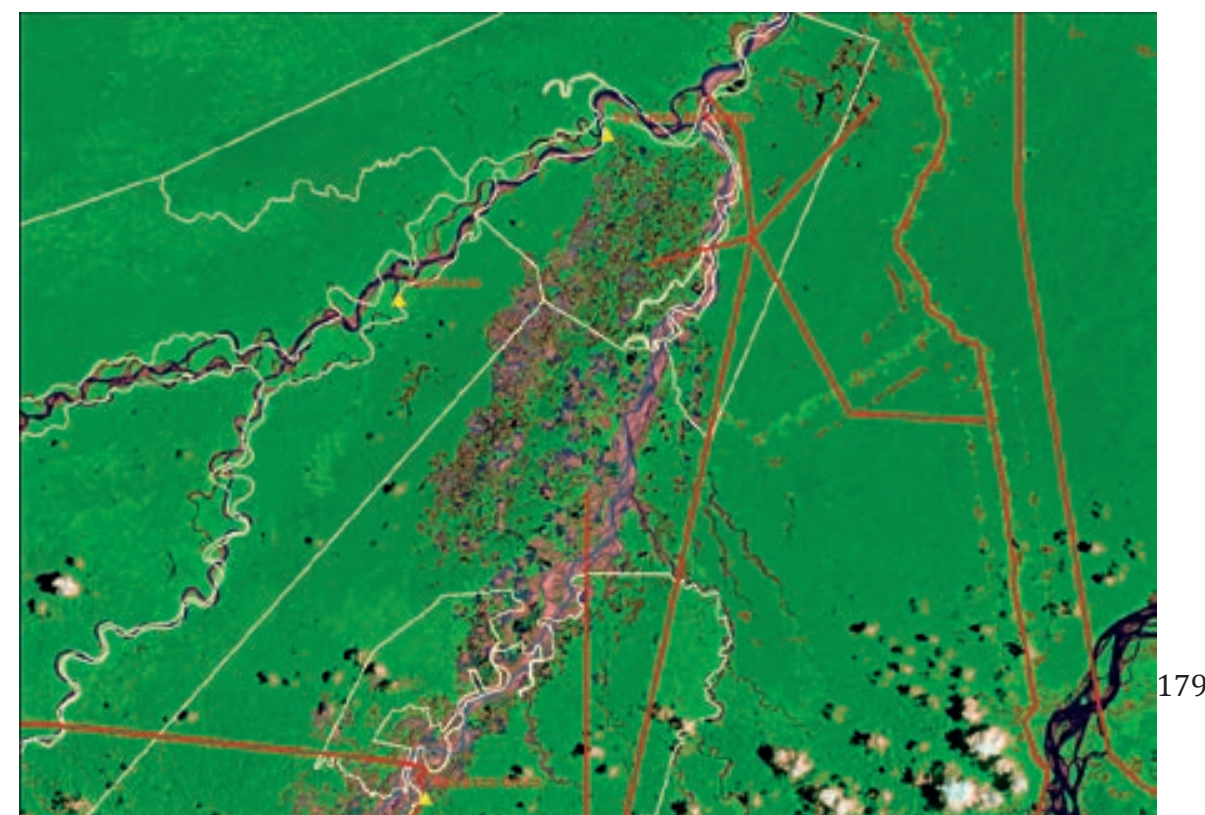


Map 4.1. Destruction caused by gold mining in Madre de Dios
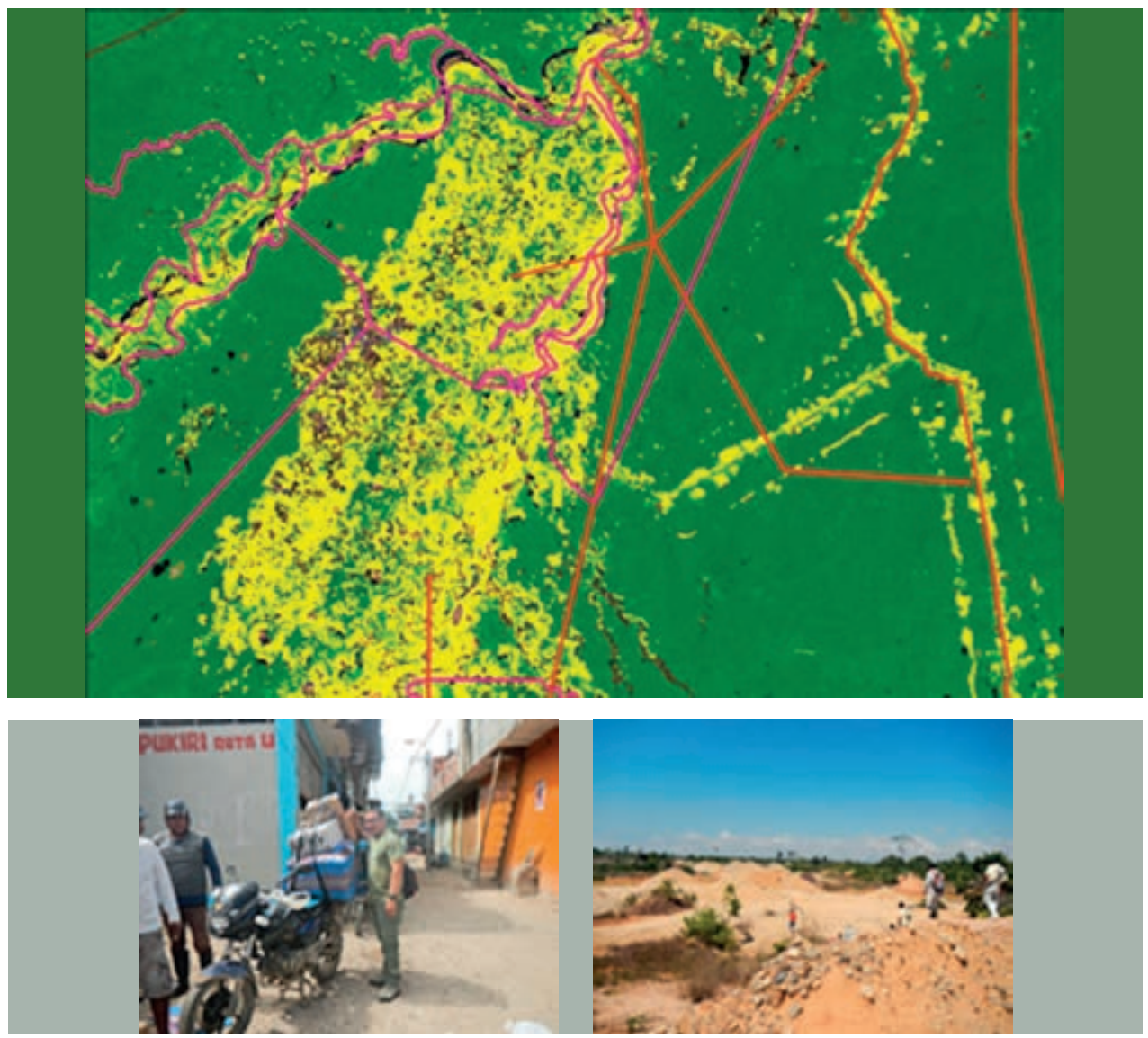

How will our generations live without water or trees?

The State publishes posters warning of the environmental dangers and threats. The following is just one example (on the dangers of mercury poisoning in fish caught in Madre de Dios).

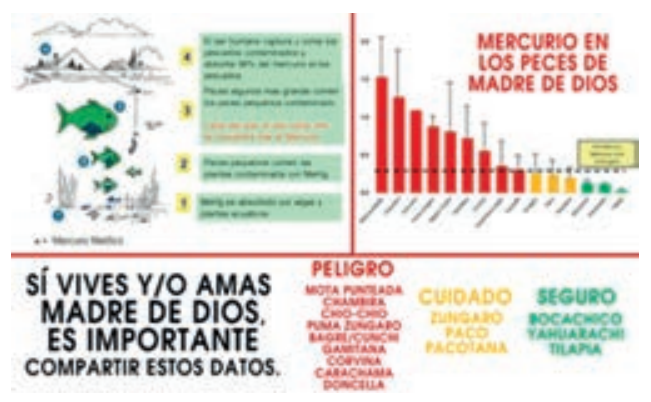


The reality, however, is somewhat different. If everything was working so well, why has the State - through the President of the Council of Ministers - had to declare a state of emergency in a number of districts of Madre de Dios?

Every morning indigenous people wake up to find yet another concession on their territories.

Change in land use is due to roads and an increasing number of settlements. This is what is responsible for the deforestation of the Peruvian Amazon, and overall responsibility for this lies with the Peruvian State. The State has now declared that 600,000 hectares of land has potential for oil palm cultivation. Approximately 60,000 of these hectares have been sown in the regions of San Martín, Ucayali and Loreto.

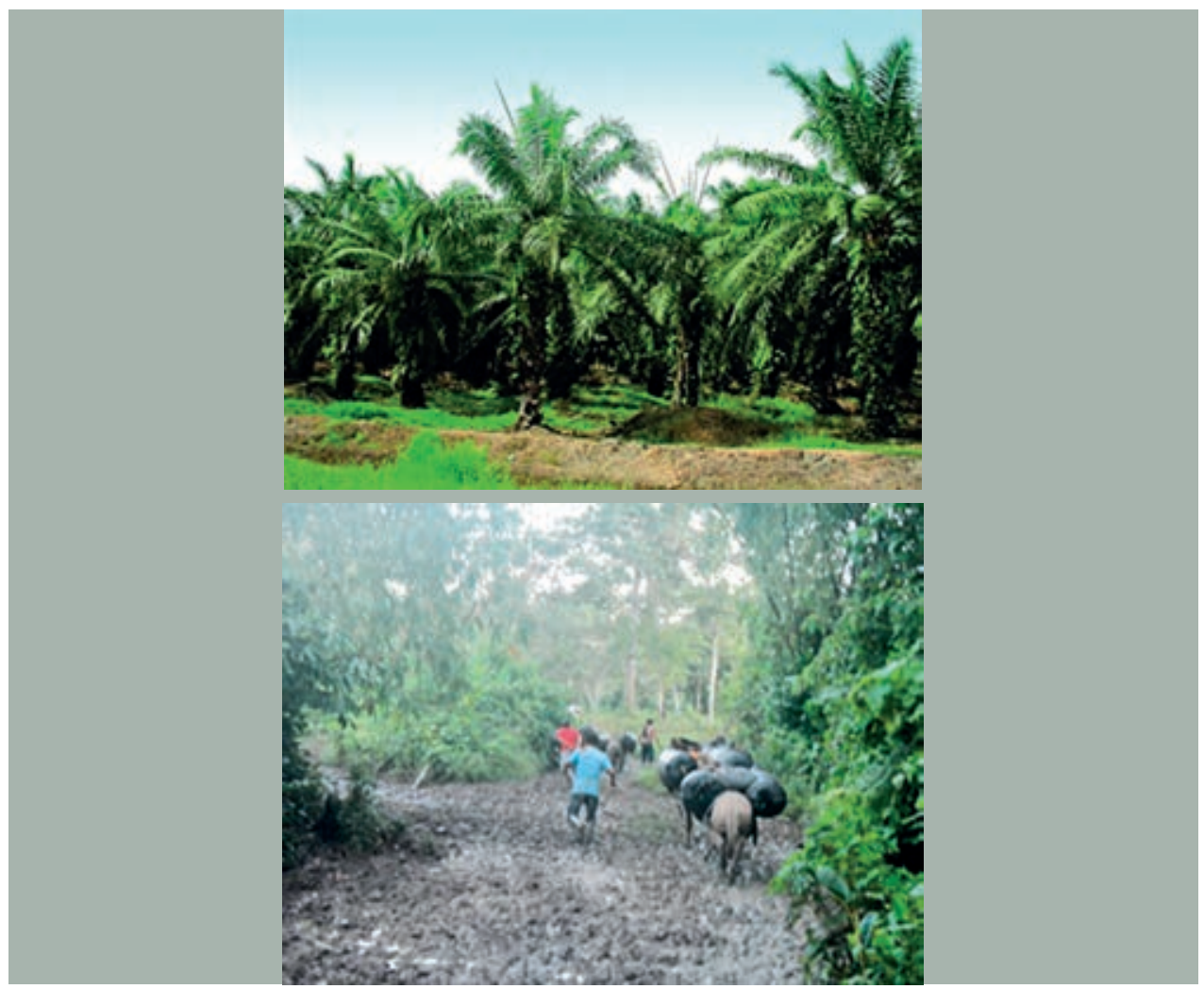

The Peruvian State is encouraging infrastructure (roads, airports, international ports, waterways, etc.) and hydroelectric megaprojects, as well as offering large tracts of land for sale for the production of oil palm, cocoa, sugar cane and other crops, arguing that economic growth will be ensured by attracting investors. Proof of this can be seen in Law No. 30230 of July 2014, which was primarily aimed at simplifying procedures and making extractive activities easier, whilst completely ignoring the indigenous territories. 
THE IMPACT OF ROADS ON INDIGENOUS TERRITORIES

Map 5. Megaproject pressures and threats on indigenous territories

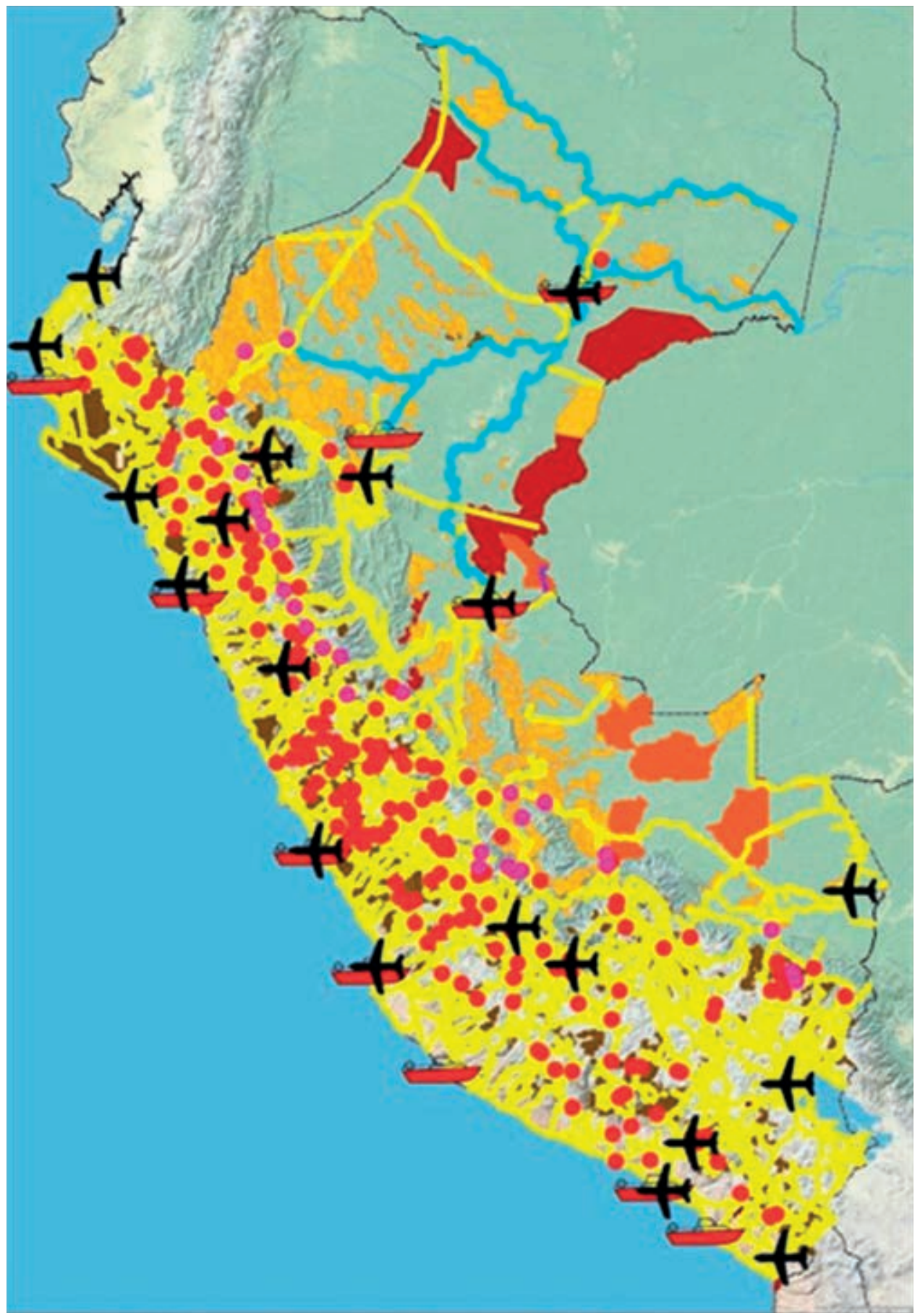


Map 6. Making the invisible visible, all kinds of concessions on indigenous territories: Indigenous territories, protected natural areas, logging and mineral concessions and hydrocarbon lots

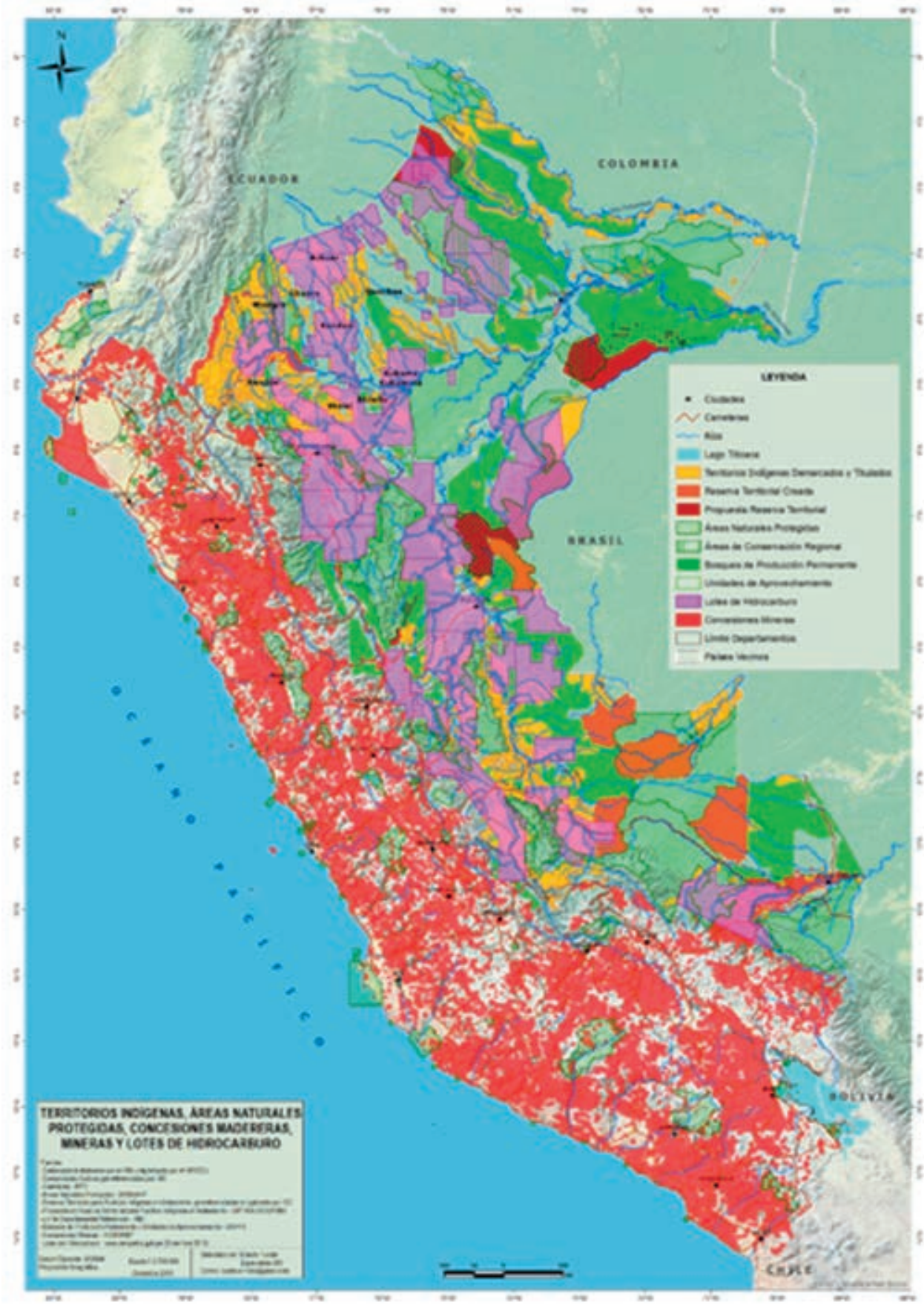





\section{IMPACTS OF HYDROCARBON EXPLOITATION ON THE INDIGENOUS WOMEN OF THE PERUVIAN AMAZON}

\section{Luisa Elvira Belaunde}

Research into the implementation and effects of the hydrocarbon industry in the Peruvian Amazon since the 1970s has taken different approaches depending on the time and place of exploitation. Despite significant differences between periods and locations, however, these studies evidence common frameworks over time and across the region, demonstrating constant violations of indigenous families' rights to territory and to life when they are directly or indirectly affected by extraction companies' activities (Chumpi, 1999; Orta Martínez et al., 2007; Chirif, 2010).

Until four or five years ago, it was rare for studies to include a gender component in their analyses of the impact of hydrocarbon exploitation on native populations, frequently implying that whatever was affecting the men was also harming the women and children of the social group as a whole. This androcentric feature, which assumed a certain homogeneity among the local population, is now being challenged and researchers have become aware of the need to pay particular attention to the situation of women (Sánchez Vásquez, 2010; Del Castillo Tafur, 2012.

While it is clear that subsoil resource extraction has had negative consequences for all segments and generations of indigenous society, recent research shows that, in comparison to men, the adverse effects of extractivist activities fall disproportionately on women, affecting girls, youths, adults and the elderly in particular. In fact, these effects are inextricably linked to changes in the social organisation of work and the gender distribution of responsibilities, the monetisation of the economy, the introduction of new patterns of consumption and the loss of resources with which to obtain food from their own plots, forests and rivers due to restricted movement in the areas in question and environmental pollution. Extractivist activities have thus truncated and distorted the potential for women's existence as people, mothers, grandmothers, wives and as members of kinship networks that weave social connections both inside and outside of their communities.

The alarming frequency of oil spills in recent years, and the serious contamination of the rivers with chemicals and heavy metals such as cadmium, mercury and lead, has further exacerbated the deterioration of women's existence, severely harming their capacity to accomplish the most basic subsistence activities or to become mothers. The massive contamination of the water and soil has made autonomous food production and healthcare provision unviable, making it impossible to create a social, cultural and nurturing environment, appropriate to 
the good development of their children and of the women themselves (FAU, 2016; Luna Amancio, 2015, 2015b, 2016).

Given the current emergency in many places around the country, the Coordinating Body for Human Rights in Peru has published a report into the different ways in which indigenous women's rights are affected in extractive contexts (CNDDHH, 2016). This report summarises the results of different studies conducted by investigative journalists and by indigenous rights defence organisations, whose documentation and reporting work has been essential in alerting the country to the worrying situation of women in indigenous communities in areas of hydrocarbon and mining activity (Castillo Guzmán \& Soria Torres, 2011; Vega Díaz \& Pineda Ortiz, 2016).

The list of direct negative effects identified in the Amazon areas analysed in the report includes women's and young children's rights to life, health, a clean environment and food. In terms of indirect negative effects, the report includes the damage done to their right to physical, psychological and moral integrity through a weakening of their role as mothers and the impossibility of feeding their children or preventing diseases caused by environmental degradation. A key point noted in a number of studies considered in the report refers to the adverse effects on women of a monetisation of the economy brought about by the extraction companies, outsourcing companies and local traders - who, invariably, support the establishment of the extraction industries, sometimes despite the guidelines of these companies and the State - providing payment in exchange for work.

This article takes up a number of the points highlighted in the CNDDHH report, and which emphasise a critique of extractivism from a feminist perspective (Gartor, 2014). My approach nevertheless, stems from ethnography and recognition of the cultural practices of the communities affected by extraction activities. The following briefly gives the example of the hydrocarbon activities established on the territory of the Kichwa people of the Pastaza River, with the aim of demonstrating the interconnectivity between the extraction companies and the presence of traders, who have contributed to introducing patterns of gender relations alien to the indigenous peoples. The case study is based on fieldwork carried out in 2009 in the Kichwa communities of Nuevo Andoas, El Porvenir and Los Jardines (Belaunde, 2010). ${ }^{1}$ In order to maintain the anonymity of the people I spoke to during the fieldwork, no names are included. I simply indicate whether they are male or female Kichwa members or mestizos from the area. It should be noted that much of the information was provided by the mestizo traders I met at that time in the area. My aim is not to verify the historical truth of their words but to present the way

1. The results of the research were presented in a written report by the NGO Solsticio in 2010 . (Belaunde, 2010). I would like to thank the Kichwa community members and traders who generously welcomed me as well as the members of Solsticio who enabled this study to be conducted. 
in which the problems were conceptualised at the time the companies' extraction activities were being established.

\section{Establishing alien gender patterns}

In her study of the extractive industries in Ecuador, Gartor (2014:2) states that extraction activities in the Amazon have eroded indigenous ways of organising production and social reproduction, realigning them according to the central presence of the companies. She considers that the introduction of paid activities, more accessible to indigenous men than women in the area, has established a highly masculinised economy in the communities, and that this has led to a breakdown in previously-existing mutual interconnections between the genders. This is in turn accentuating the disparities in the sexual division of labour, with women subordinate to the monetary incomes obtained by men. The author emphasises that, in this context of "accelerated masculinisation of the space, extractivism reshapes the gender relations and reinforces stereotypes of hegemonic masculinity". In other words, it reinforces the "patriarchal structures" promoted by mestizo settlers, who are unaware of or do not value indigenous gender dynamics and promote a rigidly binary and hierarchical sexual construct. This alien gender dualism exacerbates the idea of the active man, dominant provider, on the one hand, and the notion of the passive and subordinate woman on the other, either as a selfless mother or as an object of sexual consumption saleable through prostitution. In this categorisation of socio-cultural gender constructs, "the feminine component remains fixed in the idea of a dependent woman, subject to sexual control and abuse".

The imposition of mestizo gender patterns on indigenous peoples can also be seen in the Peruvian Amazon. The oil activities established along the Pastaza River by Occidental Petroleum (OXY) and Petroperú in the 1970s are an example of the importation of gender constructs and monetised forms of sexual consumption that have affected the indigenous Kichwa population of the Andoas region. According to the testimonials of the traders I interviewed, these patterns have become ingrained through a combination of actions on the part of the oil companies and the traders who supported their establishment in the zone from the very start.

In the same year that the Occidental Petroleum and Petroperú fields were established in what is now the community of Nuevo Andoas, a number of river traders arrived in the area with the primary aim of selling alcohol, particularly aguardiente and beer, to meet the demands of the company workers. According to these traders' accounts, they arrived in the area on their own initiative and without the companies' approval, who tried to remove them on several occasions. They were small-time traders who transported products between the indigenous settlements of the Pastaza River and the town of Yurimaguas. They maintained close relations with the Kichwa families along the river for many years, exchanging forest products (skins, wood, etc.) for industrial prod- 
ucts from the towns. They decided to settle alongside the companies' camps, attracted by the possibility of selling their industrial products to the oil workers and also of acting as intermediaries between the indigenous people and the companies, facilitating the supply of products for the workers' daily needs.

According to the traders, during the early years of company operations, Occidental Petroleum and Petroperú did not employ local indigenous people at all. All their workers came from outside. It was the traders who gave work to the Kichwa, as they needed cheap labour to cultivate their plots and look after their shops. Moreover, their presence alongside the companies created a trading movement in its own right. Nuevo Andoas rapidly became a centre for gathering and storing products from the forest, crops, fish and bushmeat brought in by Kichwa families to exchange for industrial products. These products were stockpiled by the traders and then sold to the companies or taken to market in Yurimaguas. The traders thus became commercial middlemen between the companies and the local population, consolidating the mechanism between the three closely-related components of the local economy: the companies, mestizo traders and Kichwa population.

According to the traders' accounts, however, Occidental Petroleum and Petroperú were opposed to the traders and indigenous families settling on land they believed belonged to the State and which was therefore under Petroperú's management. They tried to remove everyone on several occasions, both the traders and the Kichwa population, despite the fact that their camps were established on territories inhabited by Kichwa families prior to their arrival.

According to one male mestizo trader from Nuevo Andoas:

“They sent in tractors in 1980 but we wouldn't let them evict us. We wrote a letter to Belaunde telling him to give us passports to go to Ecuador. Belaunde agreed that we could stay and occupy up to Petroperú's wire fence. But we received no support from OXY. To set up a small market, a health post, we needed cement. They gave us nothing. They ignored us".

The conflict between the companies and traders was resolved following this attempted eviction in 1980, when the boundaries of the sectors occupied by the company, on the one hand, and by the mestizo traders, on the other, were agreed. This is how the first legal settlement was established on the site which, by then, had been renamed Nuevo Andoas. Most of the Kichwa families were living in the surrounding area, in the current communities of El Porvenir and Los Jardines. Because of the companies' interests, however, the titling of those communities endured delays and conflict for years. According to the traders, Occidental Petroleum had its own prostitution service from very early on, operating within the area reserved for the company. The sex workers, along with all company employees, came from outside, they were not indigenous. Following a violent incident in which one of the 
company's sex workers injured a foreign official, however, the sex workers were thrown out onto the street. The account that follows, which comes from a longstanding male mestizo trader in Nuevo Andoas, is shocking. I am unable to verify the details but the tale clearly invokes the real and imaginary complexity of the relationships woven between the prostitution encouraged by the company and the impact of these on the area.

"It used to be the company workers who were the consumers! All of them. So many people came! My house was $18 \mathrm{~m} \times 18 \mathrm{~m}$ and it was full, day and night, because there were people working day and night shifts. There were so many women!

OXY had a brothel that was built, with all the health services, everything in one place, and there were women there from Iquitos, Lima, and there was a 'Madam'. I don't remember her name but she supervised the other women in the brothel so that there were no problems with the workers; so that they'd go with anyone and not fall in love with any one girl. That's the problem. So she was in charge. One time, when some gringos were there, she had a drink with the boss. She got drunk and they were taking drugs. There was marijuana at that time and I'm not sure what, but anyway they were taking it.

And then she went back to the boss's camper van with him and got undressed and carried on drinking and taking drugs. Well the gringos were often abusive to the Peruvian women, they abused them, wanting to give them a black eye or break their nose. So by this point, the gringo was drunk, lying there naked on his bed. So, the Madam, she had her dildos. And some of them were massive! She had one that was bent upwards, another that was straight, like this, another hooked downwards at the tip. Then she thought: damn it, how they abuse us Peruvians! Fuck it! And she took one of the dildos, the one that was hooked at the tip, and dry. Since the guy was drunk, she stuck it in him, the whole way in. Wow! And when she pulled it out, jeez the blood! Blood, jeez! So they had to call Lima for a plane to come and take him directly to the United States.

They took him away in the night, the gringo, the forest superintendent, OXY's top boss, and he never returned. We don't know if he's still alive or not but he never came back, and the woman also disappeared. We don't know what happened to her, if she was killed or is in prison. And those women who were there, in the brothel, in their rooms, soon after that they ordered a tractor to demolish the whole place and they kicked the women out. And those women came here. They filled up my house. Drunk day and night in the town, what do you expect?" 
As they had nowhere to receive their clients, the sex workers thrown out of Occidental Petroleum ended up providing their services on the streets, in full view of the residents, without any kind of police control. It was the peak time for the bars, which were selling huge amounts of beer and other alcoholic drinks 24 hours a day. This period of economic boom, which the traders who were themselves benefiting from the prostitution boom called "Sodom and Gomorrah", lasted until the Nuevo Andoas municipality decided to create formal brothels, at the end of the 1990s, according to what I was told. In this general atmosphere of the commercialisation of sex, some indigenous girls were also brought to town to work as prostitutes.

According to a male mestizo settler from Nuevo Andoas:

"Before OXY arrived, there was no-one here. Once the company workers came, it was Sodom and Gomorrah. Girls were selling themselves for a pair of trousers, for anything. Girls wanted to dress up and sell themselves. Now the Pluspetrol workers are forbidden from leaving the site. The ones who do come are from Petroperú. Those from OXY used to come out drinking beer until morning. Pluspetrol banned the drinking of alcohol in town, and following the 2008 strike they banned workers from even going into town."

The social breakdown caused by the company workers, who established fleeting emotional and sexual bonds with the Kichwa girls, can still be seen in the number of abandoned single mothers living with their parents and bringing up their children with no help from the father. This reconfiguration of gender relations in a monetised economy has destabilised the reproduction of the social group, creating suffering and marginalisation. To this day, abandoned indigenous women and their fatherless children face rejection and mockery, particularly from mestizo women who do manage to maintain stable relationships with men from outside. The abandoned children suffer stigmatisation at school and have greater difficulty in completing their studies.

One female mestizo trader says:

"These girls were all over the place, instead of studying. When [the employees] ventured off site, they made them their "little wives". But then they left their children here and no longer come and see them. It's bullshit."

Over the years, the monetisation of the Kichwa family economy has been subject to the system existing between the oil companies, traders and indigenous population that began in the 1970s. The three components of this system have undergone changes, particularly since the hydrocarbon companies began to provide the local people with work (albeit temporary and not specialised) and since outsourcing companies and local cooperatives appeared, generating some new sources of monetary income for the male and, to a lesser extent, female population. The mechanism connecting the hydrocarboncompanies, thetraders and the Kichwa population, however, remainsin place. 
When the local community members talk spontaneously about their economy, they tend to talk about "getting by" or "foraging" or that they are "finding resources" where they can. "Foraging" is a kind of activity which is generally associated with hunting, fishing and the gathering of forest fruits. In a monetised economy, however, "foraging" expresses the idea that generating an income with which to maintain your family is rather unpredictable and difficult, and so you have to be ever more resourceful in the midst of growing difficulties if you are to achieve the social aspirations of education and territorial defence shared by all Kichwa families. The foraging economy is therefore characteristic of the highly unstable situation facing these families. It is not only a matter of ensuring the family's day-to-day survival, but of finding the means to raise their children according to the ancestral teachings taught at home and of ensuring access to school and higher education. This would then guarantee their children's integration into the stable monetised economy so that they will not have to suffer the same hardships as their parents. The just demands for their rights from companies and the Peruvian State include demands for education in order to put an end to the precarious nature of their foraging economy that they have been forced into by extraction activities.

According to one male Kichwa resident:

"What's the point of all this studying at school? It's sad to see kids without the money to continue studying. We want the companies to help us have professional children. Some kids go into the Army because there's no other career. Their dad can't pay for them to study. They go to the Army and return married."

\section{Masato, money and alcohol}

Despite all the existing frustrations and inequalities, social cohesion among Kichwa families has been maintained by means of support networks actioned through "mingas". These mingas, or work parties, enlivened with much masato (fermented cassava drink) are organised by couples from the same or nearby area who invite their neighbours to come and work and drink masato together. To understand the specific historic features of the Kichwa community and their interaction with the oil companies and traders, we need to understand the importance of masato in their lives. All basic foodstuffs from the family plots, in particular cassava and banana, are produced with the fuel of masato; houses are built and communal chores undertaken drinking masato, talking and joking together. Without masato, none of this would be possible, for it is masato that spreads the happiness and enthusiasm to work.

One female Kichwa community member says:

"Drinking masato makes you happy, it gives you strength. Without masato we wouldn't feel like working, we'd just be scratching our heads". 
No other drink compares to it. According to community members, beer only gives you the desire to go on drinking and partying, and soft drinks quench your thirst but do not give you the energy or desire to work. As for aguardiente, this often turns people violent. In contrast, masato brings people together and gives them a desire to work together or, better said, it turns communal work into a party. Even the weakest, such as anthropologists passing through the community, are capable of undertaking heavy work when drinking masato. "With masato, even you could help," the women assured me.

In some ways it could be said that, according to Kichwa thinking, masato represents a kind of anti-money and anti-oil lifestyle because it nurtures the work of the family and communal economy outside the sphere of the monetised economy that has been imposed by the companies and mestizo traders. ${ }^{2}$ At the same time, masato is an antidote to aguardiente because it combats the effects of social breakdown caused by commercial alcohol. In fact, masato is not bought and sold in Kichwa communities; it is not a commercial commodity. To drink it, you have to form part of the conviviality that is generated when masato is shared. Masato therefore creates bonds of coexistence and kinship that counter the negative effects of the monetised economy and the consequent devaluation of indigenous women, of their bodies and their work, as personified in masato.

Ethnographies on Kichwa sociability in the Pastaza region (Whitten 1976, 1988; Guzmán, 1997; Gutiérrez Choquevilca, 2012) show that the production of masato from cassava involves imbuing the product with the stamp of female identity, starting right from when the cassava and sweet potato plants used for its production are grown. To ensure their recently planted cassava cuttings grow well, the women water them with a red feed made from achiote (Bixa orellana), representing the blood of the female owner of the plot. When they water their plants, the women also spread achiote on their chin, explaining that they are in this way getting ready "for the cassava to drink our blood" (Guzmán, 1997:76). The cassava plants thereby form a bond with the plot owner. Masato gives the economy a sense of shared existence, forming a part of the bodies of those who are fed and strengthened by drinking it, and who use their strength to produce more masato together whenever they sow a new field. In other words, masato works directly on the bodies of people without there being a need for monetary reward. In contrast, where there is no masato there must be money, as some Kichwa women explained to me: "Without masato, people want to be paid". According to community members, the money received in payment for work done in the companies is compensation for the fact that it is an activity during which no masato is drunk and so it falls outside the sociability of indigenous mutual support networks.

2. The documentary "Amazonía, masato o petróleo" (Giménez, 2009) depicts the incompatibility between the developmentalist vision of the oil economy and the indigenous vision of food production and masato sharing. 
According to one female Kichwa community member:

"It [masato drinking] is banned in the company but they pay, and so the men make the effort."

Relationships with the mestizo are also largely mediated by their attitudes towards masato. The disdain most mestizo show for masato fermented with women's saliva is a point of symbolic relevance both for the Kichwa and for the mestizo of the area. Mestizo women explain: "We are not accustomed to drinking masato. They can't force us to accept it. It upsets them but I can't drink it." By not participating in the wheels of production and in the offering of masato, mestizo women are excluded from the network of construction of a common desire, and their participation in the work parties is superficial and irregular. In general, the mestizo only participate in communal chores as a duty and they say that, when they can, they send a day labourer to do the work for them. The mestizo who have fields also prefer to pay day labourers to avoid having to participate in a circle of reciprocal work parties.

One female mestizo settler says:

"I have my plot, yes, but I don't join in the work parties. I prefer to pay my day labourers. That way I don't have to go to other people's work parties."

According to the Kichwa women, few of the mestizo traders work their own plots. They do not want to devote their time to farming because this is indigenous work, through the mutual support mechanism of the work parties, and also because it is not part of a trader's vision to establish a plot of land. They never seem to settle. Even though they may have lived in the area for years, they still have the outlook of a small-scale river trader passing through, collecting and selling merchandise wherever they can. Their presence in Nuevo Andoas, for example, is dependent on the presence of the companies.

One male Kichwa community member says:

"If the companies go in the future, do you think the traders will stay behind? No! They'll go as well! They've only come here to make money, nothing else."

In contrast, the Kichwa's relationship to the land is based on communal ties to territory through masato. Marriage is the key factor in this process of union with territory. Marriage to someone from outside can therefore signify its destruction. Given that, generally, the settlers refuse to participate in work parties, marriage to a settler means a Kichwa woman will leave the community circle. Not having a partner to organise their own work parties or to participate in the work parties of other couples from the community, the woman will also find herself outside the female circle of recognition of plot owners, who feed and encourage each 
other with masato made from their blood and saliva. This breakdown in the flow of female solidarity results in a weakening of the woman's social identity, and she often stops preparing masato for daily consumption, only preparing it occasionally.

Within Kichwa couples, affections are maintained through masato. The capacity to reach agreement and conduct work in pairs and in the community is a model of indigenous sociability known as sumak kausai or alli kausai in Kichwa, meaning, "living well", which parents pass down to their children through example and words of advice, because "living well is living with good conversations. Living peacefully."

One male Kichwa community member notes:

"Living well, in our home, is planning for the way we want to live in our home. Not only in the home but in our community and so we plan. I plan, and I do and I live better."

In the past, and sometimes even now, families would get up very early and watch the sun rise together, talking, "tandarina", planning their day, recounting their dreams and advising their children. At these times, they would drink a weak form of masato, known as kuñush masato. Kuñusheando as a family, and make important decisions. Meetings at sunrise were also the main method of planning among neighbouring families who, generally, were closely related.

One male Kichwa community member says:

“The curacas (chiefs) would rule: 'You are living here in a curaca house, call the young.' They would coordinate at dawn; they would perhaps already be taking wayusa (Ilex guayusa) or their kuñush masato. They'd say: 'Over there are a couple of houses, go over there, tell them, call them, invite them to one of the houses with their families, bring the masato.' And another youth also: 'Come here because we are going to meet to talk.' Tandarina means 'meet together' to talk, discuss. Meeting to discuss things of concern, kuñushkeando. The curaca made the decisions about what we had to do, and also what they had to do. And so there was coordination. There was no other way. There'd be a horn, 'poop, poop'. Once everyone was notified, they'd come back and then blow the horn to gather everyone. This is how people were called to meetings."

The allocation of tasks assigns men to the tasks considered heaviest, such as tree felling, hunting and fishing. Women are given the responsibility of looking after the family plot, the house, the harvest and food preparation. The man is also responsible for providing the family with daily necessities, and money to buy medicines, utensils, notebooks and clothes. The ideal of the man as the purveyor of food and merchandise is dependent on his wife's cooperation and a certain subordination to her husband, both in the daily chores and as regards the family's public authority. 
One female Kichwa community member says:

“Being a woman, you can't ignore your husband. To live well, 'Give me masato, give me water,' the man will say. If the woman takes no notice, they end up fighting all the time."

The success of a marriage is, however, believed to depend primarily on the hardworking nature of the husband. Parents advise their sons from a young age not to be work-shy and to provide their wife with everything she needs for the family.

In the words of one Kichwa man:

"I was brought up by my uncle. He advised me: 'When you grow up, you will have your own wife to live well with. At whatever point in your life you get a wife, you have to think about working. Don't be lazy. When a man has a wife he needs to work hard.'"

A hardworking man is much appreciated by his wife and also his parentsin-law, with whom he maintains a close relationship of support, respect and some subordination throughout his life. To ensure they gain a good son-in-law, parents prefer to give their daughters away before, as they put it, they fall pregnant. Young girls are generally matched by 15 or 16 years of age. At the same time, women value their independence and, when they get old, many widows perform the tasks of both sexes with pride.

One female Kichwa community member says:

"Although I am widowed, this is how I live. I go to the field in his (her now deceased husband's) canoe, I harvest my cassava, I peel it. This is how I live. I'm not expecting another man to come along. I'm not of an age to sit in my hammock waiting. I may be getting old but I have plenty of banana. Who is going to get water, firewood for me?"

The women expect the men to generate enough money to be able to buy essential commodities for the family and, in particular, to cover the cost of the children's education which, according to community members, is extremely high. The women also grow produce to sell on their plots and they provide some paid services, but income generation is primarily a male responsibility. The money generated by working for a company or with traders, or through the selling of forest products, not only enables men to fulfil their roles as providers and to reinforce their authority; it also contributes to a weakening of the union between the couple and their integration into the community. This is because part of the money earned is often used to buy alcohol. Commercial alcohol has the complete opposite effect of masato.

The consumption of aguardiente and beer is a public health issue as well as an ongoing societal problem in many Kichwa communities, particular- 
ly those close to Nuevo Andoas. It involves expenditure that accounts for a significant proportion of the men's incomes, and is particularly destructive among young people who are unable to continue their higher studies after finishing school and who find themselves frustrated in their communities. Masato, however, requires no outlay. On the contrary, it generates wealth, health and union. If it were not for the desire for masato among Kichwa community members, the impact of oil activities in the Pastaza basin would have been far more devastating.

The vast majority of serious problems between couples relate to incidences of domestic violence when men are drunk on aguardiente. This is quite common and, to some extent, tolerated, so much so that it is felt that a woman who loves her husband will look after him when he is drunk so that he avoids hurting himself or suffering an accident. However, if a man is excessively violent it is likely that his wife will seek a separation. The husband may also be punished by his wife's family and the community authorities. He will be held in the local jail for a day and a night and afterwards given some advice.

"The authorities advise him not to live that way because by getting drunk he has been hitting his wife." (male Kichwa community member)

The importance of masato lies not only in its power to mobilise gender and kinship relations by creating a non-monetised economy but in its ability to dissipate or, at least, manage suspicions and accusations of envy within the community. The sharing of masato and participation in mutual help via work parties enables circles of trust to be built that are woven over and above any distrust, suspicions or accusations that may arise between people on a day-to-day basis. During work parties, people work side by side, drinking and laughing with others with whom they may have differences but with whom there is also a common bond due to the shared masato. In other words, masato channels the desires of one person towards the desire of all those who share it.

The desire for money, however, fragments communities and families; it creates divisions, rivalries and envy. Above all, it creates envy of those who show off about having more wealth than others in the community. The desire for masato is a force that brings the Kichwa together, and gives them the capacity for their own political action. According to one male Kichwa member, referring to the lack of resources provided by the oil companies to build a school, when there is no money it is masato that enables intentions to become reality. "We have built our little village up on masato," he told me.

\section{Final considerations}

The transformation of gender relations described on these pages in relation to the Kichwa people of Pastaza (based on testimonies from mestizo traders and indigenous community members) has similarities with changes noted among other 
peoples of the Amazon. Bearing in mind the differences in location, time and also the socio-cultural and historic features of each population, it can be seen that the impact of hydrocarbon companies' activities on the indigenous populations, in particular the women, is occurring in tandem with the impact of the activities of mestizo traders who have arrived in the area. These traders are operating as middlemen between the indigenous population and the companies, helping to establish new gender patterns and a monetisation of the economy and of social relations, including emotional and sexual relations. A comparative study of the perception of these impacts on the part of indigenous women and men enables consideration of the different forms of interconnection between the extractivist companies, the mestizo traders, the changing patterns of gender relations and the monetisation of the economy (Fontaine \& Le Galvez, 2010; Cárdenas, 2017; Macdonald, 2015).

The gender disparity introduced by the company workers and traders reproduces mestizo values of masculinity among indigenous families, largely measured by the capacity to consume sex and alcohol purchased with money obtained as payment for extractivist activities. Prostitution has become an integral part of accessible relationships in the communities, where sex is just one more commodity available to men. Furthermore, the monetisation of the economy and, more widely, of social relations, has given indigenous men the advantage as being the providers of the family food, being responsible for providing goods that indicate prestige and which give the male provider great symbolic status. Women's testimonies (gathered by diverse Amazonian indigenous organisations, working to defend indigenous rights) warn that practices of plundering subsistence resources and contaminating the territories lead simultaneously to an escalation of violence against women and girls, an exacerbation of gender inequalities and the sexual exploitation of indigenous girls and adolescents (International Commission of Jurists, 2016; Kerremans, 2014; CHS Alternativo, 2011; Mujica \& Cavagnoud, 2011).

Given the alarming frequency of hydrocarbon spills in recent years, particularly in areas crossed by the Norperuano Oil Pipeline, the level of river pollution has, in many places, made the water unsuitable for domestic use, personal hygiene, fishing, sowing or gathering of plant and animal-based aquatic products, which used to form the basis of a family's livelihood (IDL, 2016; Campanario \& Doylle, 2017; Fraser 2015). The severe environmental degradation has led to an unprecedented lack of subsistence resources. It is no longer possible to hold work parties because there is no cassava to make masato with and share the work. This loss of food self-sufficiency has exacerbated the monetisation of the local economy in the communities and, at the same time, the monetary dependence of women upon men. The men are not managing to meet the monetary expectations and demands of their families, and so they are forced to travel long distances to work, and for long periods, sometimes never to return. Given the current level of unprecedented abandonment, indigenous women have found an ally in the media and have taken up political activism to make their voices heard (López Díaz, 2015; Castillo, 2016; Paraná, 2016; Radio Ucamara, 2016). 


\section{BIBLIOGRAPHY}

BELAUNDE, Luisa Elvira (2010). Estudio antropológico de los impactos de las actividades petroleras sobre El pueblo Kichwa de la cuenca del Río Pastaza. Elaborado para el Programa de Defensa de Derechos Indígenas. Solsticio. Lima.

CAMPANARIO Baqué, Yaizha and Doyle, Cathal (2017). El Daño no se olvida. Impactos socioambientales en los pueblos indígenas de la Amazonía Norperuana. Lima: Equidad. CÁRDENAS Palacios, Cynthia (2017). A doença do petróleo. Extração petroleira e os Achuar do rio Corrientes na Amazônia peruana. Master's thesis. Universidade Federal do Pará (UFPA).

CASTILLO, Diego (2016). Indignante: a estos niños les pagaron 2 soles por limpiar el derrame de petróleo de PetroPerú. http:/ / utero.pe/2016/02/22 / indignante-a-estos-ninos-les-pagaron-2-soles-por-limpiar-el-derrame-de-petroleo-de-petroperu /

CASTILLO Guzmán, Gerardo \& Soria Torres, Laura (2011). Diagnóstico de justicia de género en los procesos de consulta de proyectos extractivos en Bolivia, Ecuador y Perú. Lima: Oxfam Societas.

CHIRIF, Alberto (2010). Petróleo y pueblos indígenas en el Perú: una visión histórica. Text presented at the event "40 Años de Petróleo en Loreto", organised by the Peruvian Environmental Law Society (Sociedad Peruana de Derecho Ambiental).

CHS Alternativo (Capital Humano Y Social Alternativo) (2014). Explotación sexual de niñas y niños adolescentes en la ciudad de Iquitos. Iquitos: CHS Alternativo.

CHUMPI, Marcelino (1999). Explotación petrolera y minera en los territorios Shuar. Problemas y posibles planteamientos. Quito: Abya Yala.COMISIÓN INTERNACIONAL DE JURISTAS (2016). Industrias extractivas, derechos humanos y conflictos sociales en el Perú. Mission Report. CIJ. Switzerland.

COORDINADORA NACIONAL DE DERECHOS HUMANOS (National Human Rights Coordinating Body) (2016). Sobre vulneraciones diferenciadas a los derechos humanos de las mujeres indígenas en contextos de actividades extractivas en el Perú. Report submitted to the Inter-American Commission on Human Rights in the context of its $159^{\text {th }}$ period of sessions. Petitioner: Grupo de Trabajo sobre Pueblos Indígenas CNDDHH. Lima.

DEL CASTILLO Tafur, Mary Cynthia (2012). Ideas de progreso entre los trabajadores asalariados indígenas: el caso de los machiguenga del Proyecto de Gas Camisea. Sociology degree thesis. Pontificia Universidad Católica del Perú.

FAU. Fondo de Acción Urgente - América Latina y el Caribe (2016). Extractivismo en América Latina: Impacto en la vida de las mujeres y propuestas de defensa del territorio. Bogotá. FAU.

FINER, Matt \& Orta Martínez, Martí (2010). A second hydrocarbon boom threatens the Peruvian Amazon: Trends, projections and policy implications. In: Environment Research Letters. $\mathrm{N}^{\circ} 5$.

FONTAINE, Guillaume \& Le Galvez, Marc (2010). Dos perspectivas indígenas en torno a la extracción de gas en la Amazonía Andina: el Proyecto Camisea (Perú) y la empresa comunitaria Amazonía Gas (Ecuador). En: Desarrollo con identidad: Gobernanza económica indígena: siete estudios de caso. Ed. Gros, Christian \& Foyer, Jean. Actes et Mémoires de l’Institut Français d’Études Andines, N²8, Limas: IFEA, Flacso. Pp. 83 - 120.

FRASER, Barbara (2015). Oil and indigenous communities. ReVista Harvard Review of Latin America, pp. 66-70. 
GARTOR, Miriam (2014). El feminismo reactiva la lucha contra el 'extractivismo' en América Latina. http:/ / www.lamarea.com/2014/02/17/ecuador-extractivismo-mujeres / GIMÉNEZ, Josep Ramón (director) (2009). Amazonía, masato o petróleo. Documentary produced by Lliga dels Drets dels Pobles, Cataluña. https: / / vimeo.com/24410764

GUIDI, Ruxandra (2016). Pueblos indígenas obligados a limpiar un derrame de tres mil barriles en la Amazonía peruana. https: / / es.mongabay.com/2016/02/ pueblos-indigenas-obligados-a-limpiar-un-derrame-de-3-000-barriles-de-petroleo-en-la-amazonia-peruana

GUTIÉRREZ Choquevilca, Andre-Luz (2012). Voix de 'maîtres' et chants d'oiseaux : pour une étude pragmatique de l'univers sonore et la communication rituelle parmi les quechua runa d'Amazonie Péruvienne. Doctoral thesis. Université de Paris Nanterre.

GUZMÁN, María Antonieta (2016). Para que la yuca beba nuestra sangre. Trabajo, género y parentesco en una comunidad kichwa de la Amazonía Ecuatoriana. Quito: Abya Yala.

INSTITUTO DE DEFENSA LEGAL (2016). Comisión de Justicia, Paz y Derechos del Vicariato de Iquitos. Reúnen el material más completo sobre los derrames de petróleo. https: / / www. servindi.org/actualidad/19/11/2016/ material-sobre-derrames-de-petroleo-en-la-amazonia

KERREMANS, Sarah (2014). Memorial para el tribunal ético por los derechos de la naturaleza: Cuatro cuencas contaminadas de Loreto, Iquitos: Alianza Arkana.

LÓPEZ Díaz, Antonio (2015). Cuninico, allí donde la selva se tiñó de negro. Se cumple un año del vertido del Oleoducto Norperuano que contaminó las aguas del río Marañón y afectó a la etnia indígena kukama kukamiria en la Amazonía peruana. https: / / elpais.com/ elpais / 2015/11/20/ planeta_futuro/1448039716_035520.html

LUNA Amancio, Nelly (2015). In the shadows of the extractive industry: a hard road for indigenous women. In ReVista: Harvard Review of Latin America. Pp. 70 - 74.

LUNA Amancio, Nelly (2015b). Las sombras de la industria extractiva y el difícil camino de la mujer indígena. https:// revista.drclas.harvard.edu/book/las-sombras-de-la-industriaextractiva-y-el-dif\%C3\%ADcil-camino-de-la-mujer

LUNA Amancio, Nelly (2016). La maldición del petróleo acosa a las mujeres indígenas del Amazonas. http:/ / ojo-publico.com/174/la-maldicion-del-petroleo-acosa-a-lasmujeres-indígenas-del-Amazonas

MACDONALD, Theodore (2015). Beyond dinosaurs and oils spills: Oil development and Amazonian Indigenous Peoples. In: ReVista: Harvard Review of LatinAmerica. Pp. 56 - 61.

MUJICA, Jaris; Cavagnoud, Robin (2011). Mecanismos de explotación sexual de niñas y adolescentes en los alrededores del puerto fluvial de Pucallpa. Anthropológica, XXIX (29), pp. 91-110.

ORTA Martínez, Martí; Napolitano Dora; Maclenan, Gregor; O’Callaghan, Cristina; Ciborowski, Silvia; Fabregas, Xavier (2007). Impacts of Petroleum activities for the Achuar people of the Peruvian Amazon: Summary of existing evidence and research gaps. In: Environmental Research Letters, $\mathrm{N}^{\circ} 2$.

PARANA, Flor (2006). Cuninico Impacto sobre las mujeres-vídeo.http: / / larepublica. pe / politica / 847687 -juez-de-nauta-escuchara-indigenas-victimas-del-derrame-de-petroleo-en-cuninico

RADIO UCAMARA (2016). Consuelen a mi pueblo cuninico 2 años después - video. https: / / www.youtube.com/ watch?v=hws6RQugQPI 
SÁNCHEZ Vásquez, Melisa (2010). Cambio social entre los machiguenga: el caso de Koribeni y Matoriato. Gazeta de Antropología. 26 (1), article 22.

SICUANGA Runa (1988). The other side of development in Amazonian Ecuador. Urbana: Chicago University Press.

VEGA Díaz, Ismael; Pineda Ortiz, Wendy (2016). Estudio de la actuación de las empresas petroleras Perenco en el lote 67 y Maurel ET Prom-Pacific Rubiales Energy en el lote 116. Lima: CAAAP y CooperAcción.

WHITTEN, Norman (1976). Sacha Runa: Etnicity and adaptacion of Ecuadorian jungle kichwa. Urbana: University of Illinois. 


\title{
DEFORESTATION IN MADRE DE DIOS, ITS IMPLICATIONS FOR FIRST PEOPLES
}

\author{
Thomas Moore
}

The Madre de Dios River Basin in the southern tropical forests of Peru is one of the regions of the world with the highest levels of biological diversity and intact primary forests. It covers 11,193,298 hectares in the Peruvian departments of Madre de Dios, Puno, and Cusco (ANA 2010: 4-6). This area includes $96 \%$ of the territory of Madre de Dios, $32 \%$ of Puno and $12 \%$ of Cusco. It also includes all of the traditional territory of the Harakbut ${ }^{1}$ people, and important parts of those of the Ese Eja, Matsigenka, Yine and Iñapari.

Until the 1970s, the Madre de Dios Basin was exceptionally isolated from the rest of Peru. There were no easily transited roads. The trip between Puerto Maldonado and Puerto Luz on the upper Karene or Colorado River took six days by river. There was abundant hunting and fishing and a wide diversity of cultivated and collected plants. Today one can reach Puerto Luz from Puerto Maldonado by road in four hours, and both game and fish are scarce. These notes have the purpose of explaining the changes introduced by external agents and their impacts on the first peoples of the region, especially from the loss of forest cover and wildlife over the past four decades.

The Peruvian Government has recognized the high biological and cultural diversity of this area and has established five natural protected areas (NPA) there. These include the Manu National Park (MNP) of 1,716,295 hectares; the Bahuaja-Sonene National Park (BSNP) of 1,091,416 hectares; the Tambopata National Reserve (TNR) of 274,690 hectares; the Amarakaeri Communal Reserve (ACR) of 402,336 hectares; as well as the Upper Purús National Park (UPNP) of 2,510,694 hectares, which is partially within the Madre de Dios Basin. These NPA have been protecting the flora and fauna of the Madre de Dios forests, even while they have not respected the right of first peoples of the region, whose territories they have usurped. Moreover, to protect the isolated first peoples of the region from outside encroachment onto their habitat, the Peruvian Government has established the Madre de Dios Territorial Reserve (MDTR) of 829,941 hectares to the east of both the MNP and the UPNP. Additionally, there now are 25 smaller private conservation areas (PCA) in Madre de Dios, requested by tourism enterprises and civil society-based conservation projects.

1. Harakbut is the name of all of the ethnolinguistically related people who speak a single language, Harakbut. It includes seven sub-groups, one of which now calls itself Arakbut. 
Thus, approximately $60 \%$ of the land base of the southern and western Madre de Dios Basin is formally protected. However, the rest of the Basin is subjected to "development" initiatives, conceived outside the region that have aggressively assaulted the remaining forested areas, resulting in extensive deforestation and loss of biological diversity, as well as important other natural resources, including water. To this pattern, we also need to mention the aggressive enclosure of the first peoples' territories. I argue that these processes are the result more of erroneous policies than of the evil nature of the actors and stakeholders involved, who should have been stopped. These policies need to be revisited with more strategic planning and radical change.

\section{Deforestation history}

The Madre de Dios Basin mostly lacked a continuous presence of the Peruvian State and of non-indigenous peoples until the first years of the 20th Century, unlike other areas of the Peruvian Amazon. From Inka times in the 15th Century there was gold mining in Carabaya on the upper Tambopata River and along the Arasa River, as well as coca plantations in the Q'osñipata Valley in Cusco. These activities continued during the Colonial period, with greater intensity in the 16th Century, declining afterward. They had little long-term impact on the forests, but there were violent conflicts with the first peoples, the ancestors of the contemporary Harakbut, Ese Eja, Matsigenka and Yine, who withdrew from the immediate areas occupied by these invaders of their territories. The adventurous penetrations of the 16th Century Spanish conquistadores were ephemeral and ended in failure. Franciscan, Dominican, Jesuit, and Augustinian missionaries only reached the southern limits of the Basin in colonial times and did not incorporate first peoples, unlike the situation in other areas of the Peruvian Amazon.

In the mid-19th Century explorers seeking quinine bark (Cinchona officinalis) arrived at the southern reaches of the Madre de Dios Basin. They had violent encounters with the ancestors of the Harakbut and Ese Eja, but relatively little impact on the forests where this species was found, largely because of the resistance of these first peoples. Following the theft of the corresponding genetic materials and the establishment of quinine plantations by Europeans in southeast Asia, the extraction of wild quinine collapsed and gave way to rubber extraction. Prior to the rubber boom, the boundaries with the first peoples of the Madre de Dios Basin were elastic, advancing and retreating according to market strength of the commodity of the moment ${ }^{2}$.

The process of rubber (Castilla elastica and Hevea brasiliensis) extraction, between the end of the 19th Century until approximately 1920, was different. Many trees of both species were lost, but the technology employed in those times did

2. This history is summarized from more detailed information in my earlier writings (Moore 2003, and Moore, 2015) 
not leave devastating tracks, and nature took charge of the forest recovery. The impact on the first peoples was much greater. The Atsahuaca, Yamiaca and most of the Iñapari disappeared completely from Peruvian territory, either enslaved or killed, while the Yine, Mashko Piro, Harakbut, and Esa Eja experienced massacres that greatly diminished their populations, retreating to areas where there were few rubber trees, to avoid submission to the invaders of their territories. Some Witoto, Bora, Kichwa Lamas, Kichwa Canelos, Amawaka, and Shipibo were brought to Madre de Dios to serve as labor in the rubber industry.

Between the collapse of the rubber economy in the second decade of the 20th Century and the 1970s, the situation in the Madre de Dios Basin was one of subsistence and persistence, both for the people who had come to Madre de Dios with the rubber tappers and for the remaining first peoples. They either remained in relative isolation or were temporarily incorporated into the Dominican missions that had come with the rubber barons. The former rubber patrons consolidated their rustic farms, combining production of forest products including rubber and medicinal plants with cattle raising and the production of alcohol from sugar cane for local markets. The Ese Eja, Amawaka, Shipibo and Kichwa Canelos worked in these activities as primary producers.

Beginning in the 1930s, Brazil nuts entered into production, going out through Bolivia initially and, from 1943 on by air through Lima. Small-scale gold mining returned to the Arasa and Inambari Rivers between 1880 and 1923 and, from 1931 on, in the context of the global Great Depression, but operations in all of these activities were rudimentary with minimal permanent impact on either forests or first peoples, whose elastic boundaries with the extractive fronts of the moment advanced and retracted following market cycles.

No technically compiled census of the population of Madre de Dios during the rubber period exists, but in 1903, Commissioner Juan S. Villalta (1904: 7) recorded 489 colonists in the department. In 1911, the number was estimated at 5000 people with ties to rubber extraction activities and trade (Ballón Landa, 1917: 65). One estimate of the first peoples in Madre de Dios was around 30,000 inhabitants (Hassel, 1905: 32).

Beginning in the 1970s, that situation began to change with greater attention on the part of the State and increased extractive activity. Here we shall focus on some of the most important of such activities, road construction, more intensive placer gold mining, timber extraction, oil and gas exploration, and plans for a hydroelectric dam, in addition to direct public investment in schools, and primary health care facilities and services, and also analyze their impacts on the first peoples.

\section{Roads}

During rubber extraction times, beginning in 1906, overland transportation between the Madre de Dios Basin and the rest of Peru was by mule trail, built by 
the US-based Inca Mining Company/Inca Rubber Company under Government concession. That company had begun gold mining operations on the upper Inambari River in 1880 and went into rubber tapping farther north later on. That trail went from a railroad stop at Tirapata in highland Puno to the head of navigation on the Tambopata River at a point called Astillero, which is now on the boundary between Madre de Dios and Puno departments. Construction of penetration roads into Madre de Dios from highland areas of Cusco began in the 1960s during the first government of President Fernando Belaunde.

\section{The Penetration Roads}

The road from $\mathrm{Cuzco}^{3}$ through Urcos and Ocongate reached Quincemil on the Arasa River in 1963 and Puerto Maldonado in 1965, although it was not open to traffic during the rainy season of each year. Its continuation as far as Iberia was opened to motor vehicles in 1973, and more precariously to Iñapari on the Brazilian border in 1987.

These roads were accompanied by Government-sponsored settlements of mostly Andean colonists, who cleared the forests for several kilometers on each side of the road for their crops, principally rice, and pastures for beef cattle in a manner that degraded the tropical soils and destroyed vast extensions of natural Brazil nut forest. After a few years most of the land occupied by these colonists was abandoned as unproductive and taken over by invasive flora such as neotropical bamboo (Guadua spp.). The roads also brought with them waves of timber extractors with small sawmills who in few years depleted the natural stands of the most valuable species, including big leaf mahogany (Swietenia macrophylla), tropical cedar (Cedrela odorata), tornillo (Cedrelinga cataeniformis), and ishpingo (Amburana cearensis). This activity was intense in areas now part of the MNP between 1965 and 1975, when the timber companies were relocated.

The colonization along the road did not provoke serious conflicts with the first peoples, whose populations had declined massively from epidemics of small pox, whooping cough, yellow fever and respiratory diseases, against which they lacked natural immunity. Their remaining villages were located along the rivers, mostly distant from the penetration roads. The exception was the Dominican Mission at Shintuya at the end of the penetration road from Cuzco. There the missionaries introduced beef cattle and a saw mill, which were abandoned in the 1980s because of resistance to them from the Harakbut community there. Some Yine were involved in the timber trade through arrangements with sawmill owners in the Manu area and Puerto Maldonado. And the Ese Eja of the lower Tambopata, lower Madre de Dios and Sonene (Heath) Rivers became active Brazil nut producers for the exporters based in Puerto Maldonado, and also provided fish for the local market.

3. While the official name of the department or region is spelled "Cusco"; references to the city should be spelled with a "z", Cuzco, as it occurs in the historical literature. 


\section{The Interoceanic Highway}

From an historic meeting in 1983 in Puerto Maldonado between Peruvian President Fernando Belaúnde and Brazilian President Ernesto Geisel came a plan to connect central Brazil and its Atlantic ports with the Peruvian ports of Ilo, Matarani and San Juan de Marcona on the Pacific coast, passing through Madre de Dios from Iñapari through Puerto Maldonado and Juliaca, as well as Cuzco to the Pacific ports. The expressed need was for route to allow Brazilian soy beans and other products easier access to Chinese and other Asian markets.

The projection was that no fewer than 100 trucks loaded with Brazilian soy beans would pass through Madre de Dios every day, and the assumption was that this road, which was to be fully paved with bridges over the Madre de Dios and other rivers in Madre de Dios, would create a dynamic local economy all along the route. After three decades of modest attempts to initiate this project, with massive loans from the Inter-American Development Bank, the project was carried out between 2005 and 2011, and the highway opened to traffic, at a cost exceeding US $\$ 4.5$ billion. Dourojeanni (2006) conducted a critical assessment of the potential harmful impacts of this project before most of the construction was underway.

\section{Routes of the Southern Inter-Oceanic Highway}

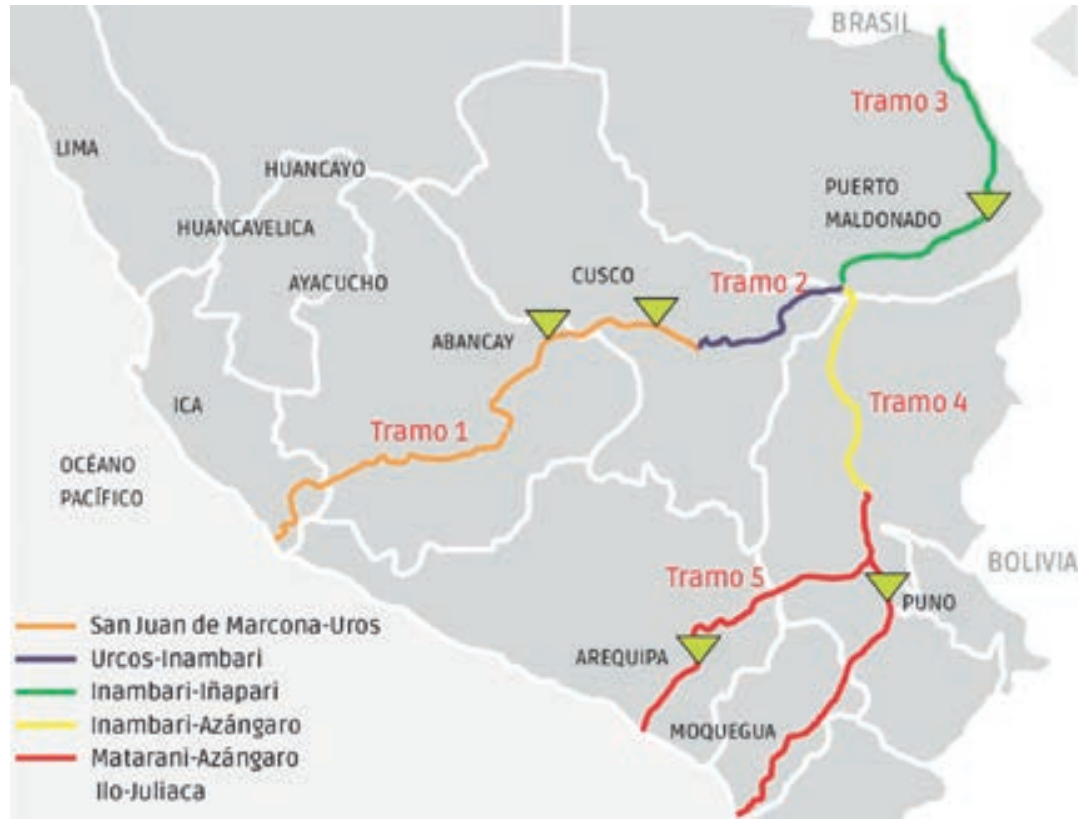

Source: Bravo Orellana (2013), p. 29.

The concessions to construct these highway sections were granted to the CONIRSA Consortium, led by Brazilian construction company, Odebrecht, during 
the governments of Toledo, García, and Humala. Those concessions includes the right to collect tolls and maintain the highway for 25 years. CONIRSA met its technical, environmental, and labor obligations in an impressive manner, although investigative journalists have uncovered evidence of widespread corruption and cost overruns, approved by successive contract amendments, involving each of the Peruvian presidents of this period. Moreover, these governments assumed obligations to bring order to the territory surrounding the highway, with land titling and conservation efforts.

To meet those obligations, the Government of Peru received an additional US\$10 million credit from the Andean Development Bank (CAF), which required a contribution of US\$7,785,957 from the Peruvian Government's National Institute for Natural Resources (INRENA) to mitigate the harmful impacts of this highway. The tasks included clearing up the legal and physical barriers to land titles for the colonists and native communities and some conservation measures by the Regional Government of Madre de Dios (GOREMAD). This budget was used to expand GOREMAD's infrastructure and bureaucracy, but few land titles or conservation measures were approved, although GOREMAD continues this process as a snail's pace from its own resources.

Today, eight years later, local transportation between Iñapari, Puerto Maldonado, Mazuko, Juliaca and Cuzco is much more rapid and comfortable. Two major wood exporting companies were established in the area near Iñapari and are producing vast quantities of wood for the global market, with questionable forest management practices. Tens of thousands of highland migrants have arrived in Madre de Dios, mainly to engage in illegal and informal gold mining operations and related trade. There are no trucks with soy beans or other Brazilian agricultural products for lack of return freight, and in Puerto Maldonado Brazilian license plates are rarely seen.

\section{The Manu Roads}

In addition to the Interoceanic Highway, over the past nine years, the district mayors of Manu Province, in coordination with GOREMAD have funded and built local roads between Punquiri on the Inambari River, near Santa Rosa on the Interoceanic Highway, to the Madre de Dios district capital of Boca Colorado with spurs to the illegal gold mining center, Delta Uno, and the Arakbut communities of San José del Karene, Puerto Luz and Barranco Chico. These local roads provide access to those communities and the ACR for colonists, informal timber extractors, and illegal gold miners, who now pose a serious threat to the primary forest areas that remain there.

All of these local roads have been built without technical-economic feasibility and environmental impact studies. They were never included in the Ministry of Transportation and Communication's (MTC) National Road Infrastructure Plan; thus, they are illegal. But that situation has not impeded their construction by local authorities. To obtain authorization for the Shintuya-Diamante road, GOREMAD presented the form required by the National System for Public Investment (SNIP) 
to obtain authorization from the Ministry of Economy and Finance (MEF). That authorization was initially questioned by Peru's National Protected Areas Service (SERNANP) as a threat to the integrity of the ACR and the MNP buffer zone. Likewise, the Vice-Ministry of Interculturality of the Ministry of Culture was concerned about threats to the isolated Mashko Piro within the MNP. However, a Congressional initiative to declare this road a national priority is still in force, and both SERNANP and the Ministry of Culture withdrew their observations under political pressure.

The threats to the first peoples are mostly invasions of their communities' titled lands and of the ACR and the MNP buffer zone by colonists, informal loggers, and gold miners, and the disease and malnutrition they bring with them. These threats also affect the isolated indigenous peoples within the MNP and its buffer zone areas.

The construction of roads by local mayors and regional governments with no formal authorization is common in the Peruvian Amazon. Chirif (2011:91-98) documents similar situations in Loreto and for the Satipo-Atalaya road in Junín. In these cases, and in Ucayali, the principal interest is for timber extraction. The sawmill owners fund the political campaigns of the candidates, and those elected correspond by lending the equipment and often funds for the illegal road construction projects.

In a section below, we consider the impact of gold mining on the ACR and the territories of the native communities of Manu and Tambopata provinces of Madre de Dios as a result of the access provided by these roads.

\section{Projected Puerto Esperanza-Iñapari Road}

Another road with a resolution of national priority initially approved in the Peruvian Congress is one between Puerto Esperanza in Purús Province, Ucayali, and Iñapari in Madre de Dios. This road was proposed by a Congressman from Ucayali, Carlos Tubino, the Pucallpa- and Atalaya-based wood industry, and a priest in Puerto Esperanza, Miguel Piovesán. The Federation of Native Communities of the Purús (FECONAPU) and the Tahuamanu Municipality in Madre de Dios oppose the initiative. It would cross $14 \mathrm{~km}$. of the Purús Communal Reserve (PCR), $105 \mathrm{~km}$ of the UPNP, which are important natural protected areas with an abundance of threatened species of flora and fauna, as well as $24 \mathrm{~km}$ of the MDTR, established in 2002 to protect the isolated first peoples who roam that area with minimal contact with the outside world, as well as $57 \mathrm{~km}$ of timber concessions, and $36 \mathrm{~km}$ of Bélgica Native Community lands with an area of impact of 34,956.9 $\mathrm{km}^{2}$ in Peru, Brazil, and Bolivia (Appling, Salisbury 2012). 
Proposed Puerto Esperanza-Iñapari Road with Impacted Protected Areas, Isolated Indigenous Reserves

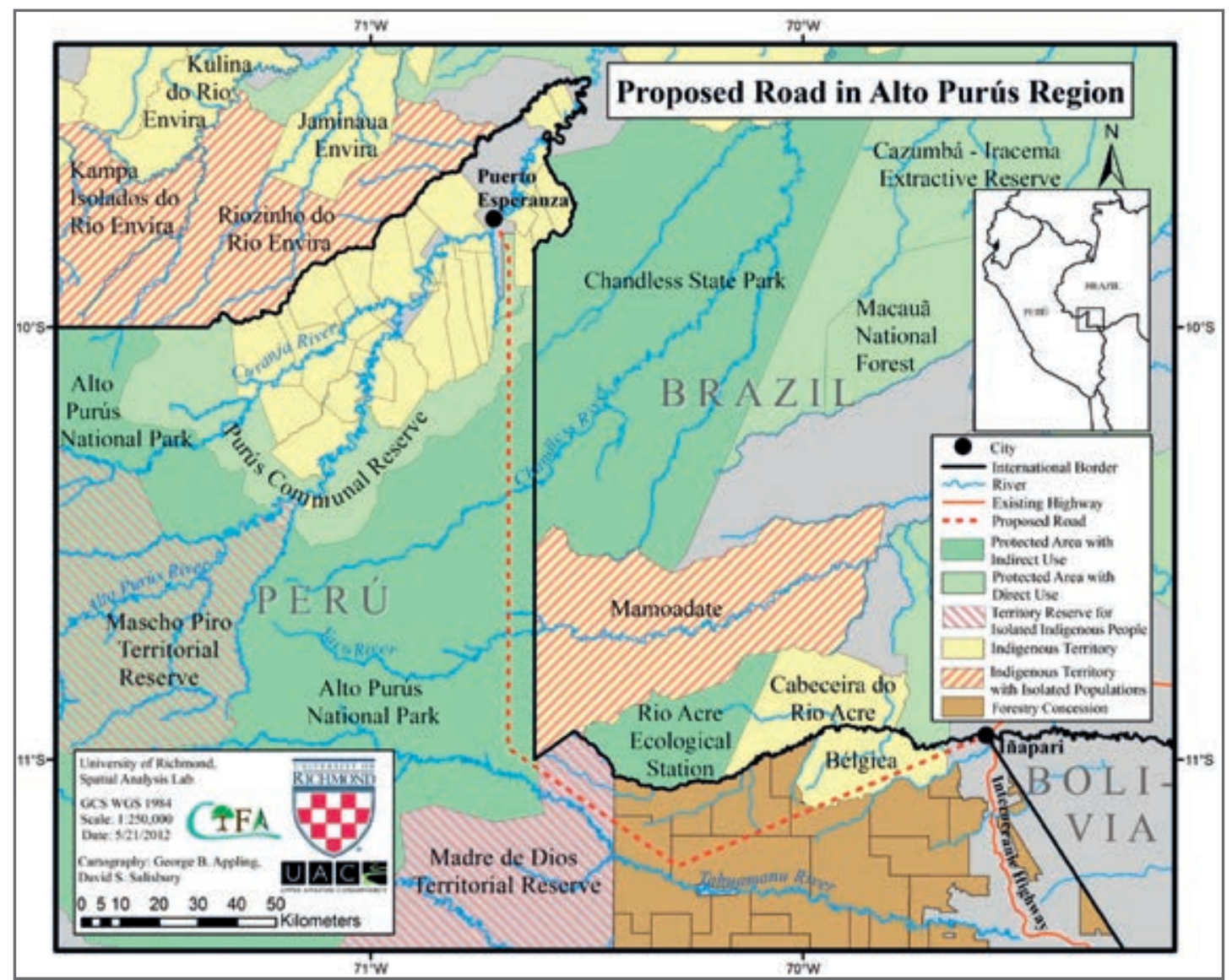

Source: https://upperamazon.org/wp-content/uploads/2012/10/ApplingSalisbury2012SocioEnvironmentallmpactsOfPurusRoad20120821.pdf]

If this road is built, it will lead to massive deforestation along its route and loss of sources of livelihood for the Yine, Mashko-Piro, Yaminawa. Amawaka, Sharanawa and Honi Kuin peoples of the Purús, Acre, and Madre de Dios watersheds.

Another projected road, included on a recent map of the MTC, although with none of the corresponding studies, is PE-55, an extension of the Marginal Highway of the Selva, originally proposed by President Belaúnde in 1963. This road would cross the MNP for 274 kilometers and reach the Bolivian border with Madre de Dios, Peru (Dourojeanni 2015). If built, it would potentially destroy the jewel of Peru for the protection of tropical forest habitats and one of the world's greatest areas of biological diversity, in addition to the habitats and livelihoods of the Matsigenka, Mashko-Piro, and other isolated first peoples. 
The impact of roads on the first peoples of Madre de Dios is one of increased pressure on their tropical forest habitats and livelihoods from colonists, loggers, gold miners, adventurers, and others who arrive more easily into these tropical forest areas because of the access provided by the roads and contribute to their deforestation.

\section{Gold Mining}

In 1973, I observed artisanal gold miners all along the Madre de Dios River between Puerto Maldonado and the mouth of the Karene or Colorado River, and also along the length of the Inambari River in Madre de Dios. These gold miners worked along the beaches in teams of four to six people, usually men, with wheel barrows, sluices, motor pumps, picks, and shovels. Mercury was used to separate the gold from the black sands that contained it. The gold-bearing sands and gravel that they removed were renewed by the successive annual floods, although the mercury remained in the ecosystem. No one was using dredges or heavy earth moving equipment, although some of the miners who had come from the Andean highlands worked with numerous personnel.

Also in 1973, the Banco Minero del Perú (BMP), which had exclusive rights to buy and sell gold, set up offices in key gold mining areas of Madre de Dios of Mazuko, Boca Colorado, and Wepetwe, and in Puerto Maldonado, to promote placer gold mining by selling tools, food items and other needed supplies to the miners at their cost, and to buy the gold at a price equivalent to the global market price, thus subsidizing the operations. The BMP granted official recognition to all gold miners who sold them gold, including the Arakbut community members; no mining concessions were allowed in the area. Although some of these gold miners were occupying the traditional lands, still lacking titles, of the Arakbut and other indigenous communities of the area, they usually sought to avoid conflict up until 1978, when the law changed and the area was opened to mining concessions ${ }^{4}$.

In 1978, Decree Law 22178, the Law to Promote Gold Mining, was approved. This law granted no rights to the native communities, some of which had been formally recognized by that time; rather it opened the areas previously under the control of the BMP to mining claims on a first-come, first-served basis, according to stipulations of the same law. Then the Government of Peru approved Supreme Decree 350-EM/DGMM on May 20, 1978, granting priority to miners previously authorized by the BMP to file claims before a 30-day deadline. However, this Supreme Decree was not published until June 19th, the 29th day of the 30-day deadline, allowing mining companies having no previous presence in the area to file claims over nearly all of the area on the 30th day, before any miners in Madre de Dios, including the native communities, became aware of it (Pacuri and Moore, 1992: 25).

4. For a detailed discussion of the social conflicts in Arakbut communities following the 1978 gold mining law, see Gray, 1986. 
So, mining companies based in Lima and some transnational mining companies, affiliated with the National Society of Mining and Petroleum (SNMP) were able to obtain mining rights in Madre de Dios, Cusco, and Puno (Moore 1983), while most of the previously established gold miners, including the native communities, were disenfranchised. Many of the latter remained in the area informally, giving rise to violent social conflicts between the gold miners who had been recognized by the BMP and those who represented the owners of the claims. Although many of the claims dating from the time of that law, which has since been replaced, are no longer in force, the social chaos that began at that time continues to this day ${ }^{5}$.

In 1978, at a place called Fortuna, near the left bank of the Madre de Dios River, gold miners from the Andean highlands discovered very high concentrations of gold in former branches of the river under two or more meters of alluvial overburden. That find led to massive informal migration of Andean gold miners to similar areas along the Madre de Dios, Inambari, Malinowski, Kaichiwe, Wepetwe, Pukiri and other rivers in Madre de Dios. Much of this more intense mining activity was initially concentrated in the areas along the Wepetwe and Kaichiwe Rivers, in traditional Harakbut territory but not currently occupied by Harakbut communities. Such intense mining has since expanded to other areas.

One of the companies that benefited from the 1978 law was Compañía Aurífera Río Inambari, S.A., (CARISA), whose principal owner, Gonzalo Sánchez de Lozada, later became President of Bolivia. CARISA introduced a bucket line dredge on the Kaichiwe River and eliminated major forested areas there and along the Wepetwe. CARISA's claims also covered the entire territory of the Arakbut community of Barranco Chico, which eventually obtained a land title over part of its lands, which did not affect CARISA's claims. After 12 years of conflict with the Barranco Chico Native Community, massive deforestation, water contamination and other environmental devastation produced by their heavy equipment, CARISA agreed to withdraw their operations from the Community's titled lands, and, as part of that agreement, they maintained their claims there, allowing the Community to work it in artisanal fashion and preventing others from obtaining mining rights over the Community's territory.

The other transnational and Peruvian mining companies also withdrew after mining out the areas of relatively high gold yield, but the remaining Arakbut

5. Although most of the "native communities" in Madre de Dios now have land titles, many of these were granted after the mining rights were established and which were not retroactive. Moreover, the Peruvian Constitution of 1993, like its predecessors, declares subsoil rights to be the property of the State, which may grant mining concessions to whom it chooses, regardless of land rights in the same territory, thus allowing for mining claims superimposed over native communities' titled lands. While mining claims or concessions under the current law bring with them obligations to compensate for right of way easements (servidumbre), most native community lands are in remote areas where there is no significant land market; so, the land is considered without value and no compensation is granted. Current regulations, also not retroactive, exclude mining concessions over titled community lands. 
and other indigenous communities in the area were left with their lands largely deforested and invaded by miners of highland Peru origin, who had arrangements with the original and subsequent mining claim owners.

\section{Area of the Wepetwe River showing desertification from gold mining}

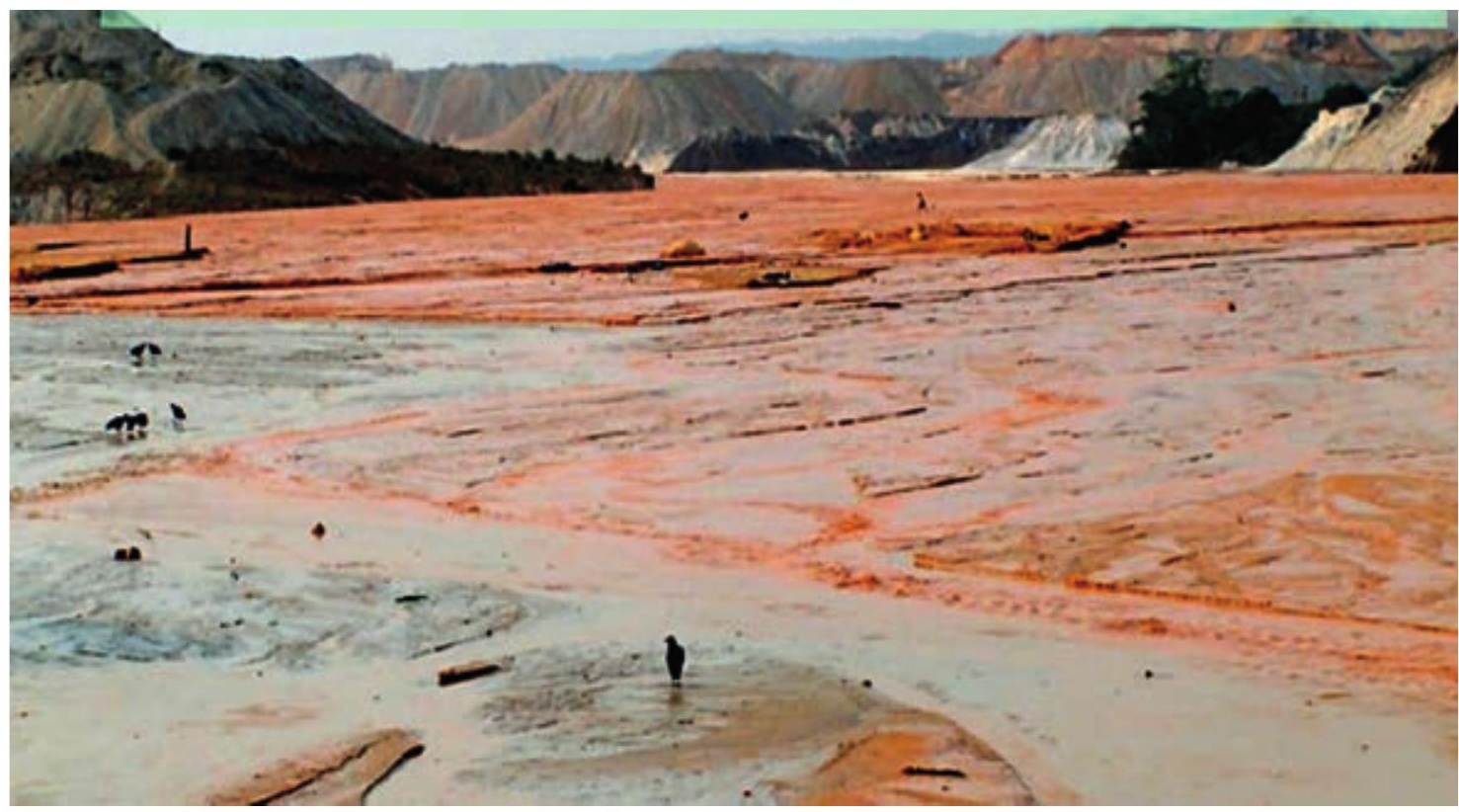

Reproduced from Ráez Luna, 2013a.

Between 1986 and 1990, with the support of the Madre de Dios Native Federation (FENAMAD) and the Puerto Maldonado-based non-governmental organization Eori Center for Regional Research and Promotion, eight native communities in the Madre de Dios gold mining area obtained their own mining claims within their titled lands. Many of these claims contained no profitably minable gold, but the communities filed the claims as a territorial defense mechanism to prevent others from obtaining claims there and extracting gold elsewhere within their territory. They maintained these claims and successfully kept out gold miners who sought to invade their lands until 1993, when the claims expired under the terms of the 1991 General Mining Law, which required payments to keep them in force that were beyond the Communities' ability to pay.

The most intense socioenvironmental conflicts in the area have been the result of the policy of the Peruvian Government to prioritize mining rights with property characteristics, over more orderly, and environmentally and socially responsible processes. The legal norms that currently apply in Madre de Dios were imposed vertically from Lima with no prior consultation with any local people. They are complex, technocratic, mutually contradictory, confusing, and impossible to apply in the area. 
The current General Mining Law of 1991, Decree Law 109, approved initially by the Fujimori Government, applies to large-scale copper and other mining in the highlands and coast, as well as to small-scale alluvial gold mining in Madre de Dios, Cuzco, and Puno. When it was adopted, it immediately was in conflict with the Environmental Code, approved months earlier. Neither law had undergone multi-sector review, nor consultations with the affected parties prior to enactment. As a result, modifications were introduced to the Environmental Code that seriously weakened it. The General Mining Law, as modified subsequently, is still in effect with a Unified Ordered Text as Supreme Decree 11-92-EM. The Environmental Code, further weakened, was replaced in 2005 by the General Environmental Law (Law 28611), which also established the Ministry of the Environment (MINAM), with more formal regulations, although without the political weight of the Ministry of Energy and Mines (MEM).

In 2001, the provisional government of Valentín Paniagua established a Multi-Sectoral Commission within the Office of the Presidency of the Council of Ministries to resolve inter-sector conflicts of this nature. While these modifications improved procedures, they were not retroactive, so that mining rights acquired previously over native community titled lands remain in effect, according to the earlier laws, and the conflicts continue. Additionally, mainly from imprecise demarcation, there are forestry concessions and agricultural rights in conflict with titled native community lands.

As a result of the global economic crisis of 2007-2008, which increased gold prices, and the opening of the Interoceanic Highway, the Madre de Dios Basin was massively invaded by informal gold miners from all over Peru. Some petitioned for mining claims; others did not. Among the areas invaded were the buffer zones of the TNR, BSNP, and ACR, as well as areas of the Arakbut communities of Puerto Luz, San José del Karene, Barranco Chico, Arasaeri, and Kotsimba. To address this problem, the successive governments of Alan García, Ollanta Humala, and Pedro Pablo Kuczynski issued numerous regulations seeking to control the illegal, informal gold mining in areas such as Madre de Dios. These regulations, which were decided upon in Lima and do not reflect on-the-ground reality in gold mining areas of Madre de Dios, Cusco, and Puno, have been largely ineffective. The military interventions they brought have only dispersed the illegal miners temporarily and increased criminal violence throughout Madre de Dios.

In 2012, the Government of Ollanta Humala issued a spate of such regulations in one more attempt to control illegal gold mining. These regulations began with prohibition of the use of dredges along the main course of the Madre de Dios River, where the banks were being undermined, destroying the trees that provide fruits that are the main source of food for Amazonian fish. Other regulations restricted access to supplies needed for gold mining, including gasoline, which was put under the control of the National Superintendent for Customs and Tax Administration (SUNAT). That measure created a major hardship for rural farmers 
and forest workers, and native communities, who needed gasoline for their work, but less so for illegal gold miners, who can bribe the police and obtain all of the gasoline they need.

One of these procedures established a new document, the Instrument for Corrective Environmental Management (IGAC) which has to be completed and complied with in order to formalize gold mining concessions, in principal an important measure for ensuring environmental compliance. But this cumbersome, and expensive process discouraged most miners from attempting to meet the requirements, while they continued to market their illegally produced gold. By October 2018, no gold miner in Madre de Dios had met these requirements; all were illegal.

\section{The Experience of the Kotsimba Native Community}

The confusion caused by these regulations is illustrated by the experience of the Kotsimba Native Community, of the Pukirieri sub-group of the Harakbut people, located on the Malinowski River near the border of Madre de Dios department with Puno. This community has been actively engaged in small-scale artisanal gold mining since the 1970s, when their activity was under the control of the BMP. Following approval of the 1991 General Mining Law, when outsiders were already petitioning for mining concessions within their still untitled lands, with support from FENAMAD, this Community petitioned for its own gold mining concession in order to protect its communal lands from further claims. Following the procedures required by the Regional Direction of Energy and Mines at that time, the Community hired professional mining engineers to prepare a technical-economic feasibility study. That study recommended they concentrate their gold mining efforts in smaller areas, where samples indicated greater concentrations of gold and use expensive earth moving equipment to remove the overburden. To finance a down payment on this equipment and guarantee the credit for its purchase, the Community entered into a partnership with a neighboring gold miner from Puno, who fronted some of the needed funds, under a share and share alike (50-50) arrangement for costs and return on their investment. They began working together in full compliance with the then existing mining regulations.

Subsequently, in 1998, the Peruvian Government provided incentives to the regional governments to undertake a process of ecological, economic zoning (EEZ), in order to meet its obligations under the Amazon Cooperation Treaty. GOREMAD reached an agreement with the Peruvian Amazon Research Institute (IIAP) to conduct this zoning process in a highly participatory manner, to define the areas most appropriate for gold mining and to limit gold mining to those areas. During this process FENAMAD and its affiliated communities, including Kotsimba, agreed to exclude gold mining claims from community lands, under the assumption that the Native Communities Law (DL22175) granted the com 
munities autonomy in economic affairs, so that they could continue to conduct their traditional mining activities and that the exclusion would prevent outsiders from gaining mining rights within community territories.

This EEZ process was approved by a GOREMAD ordinance, which defined the mining corridor excluding native community territories. However, the Ministry of Energy and Mines rejected the authority of the regional governments to decide such matters, and left the EEZ process invalid regarding mining rights, although GOREMAD continued to respect the mining corridor in its role of administering mining laws in the region. Meanwhile, the Kotsimba Community and its partner continued their work and invested 30,000 soles to develop their IGAC, which was submitted to the Regional Direction of Energy and Mines for approval, in accordance with the procedures established by the 2012 decrees.

When the Madre de Dios Regional Direction of Energy and Mines reviewed Kotsimba's IGAC, its lawyer observed that the mining concession, petitioned for a decade earlier and for which approval of the IGAC was requested, was located outside the mining corridor. Without respecting the Community's economic autonomy, the Director not only denied approval of the IGAC, but also annulled the Community's declaration of intent to comply with the new regulations, leaving it with no option for formalization of its mining claim and making its ongoing mining operations illegal.

Moreover, when the regulation prohibiting new mining rights within native community lands went into effect, it was also not retroactive, leaving most of the native communities in the area with claims by outsiders still recognized, although not formalized, and still not annulled by GOREMAD.

\section{Deforestation from Gold Mining in Madre de Dios}

Jennifer Swenson and her co-authors (2011) documented with LANDSAT images that 15,500 hectares of primary forest had been lost by 2009 in the three principal gold mining zones of Madre de Dios (Wetpetwe, Guacamayo, and Delta Uno) and that the deforestation rate was 1915 hectares per year. However, Gregory Asner and co-authors (2013) demonstrated, with higher resolution images and with verification in 166 field sites, including clandestine operations, that the area of deforestation from gold mining in the same area was 32,371 hectares with average forest loss of 6145 hectares per year after the increase that began in 2008.

Their projection was that up until 2013, more than 50,000 hectares of forest would have been lost as a result of illegal gold mining. This area is greater than all that agriculture, cattle raising, and timber extraction ever deforested in Madre de Dios. Between 2017 and 2018, according to the Monitoring of the Andean Amazon Project (MAAP), 18,440 additional hectares of forest were lost (Sierra Praeli, 2019). 


\section{Area of La Pampa, kms 100-115 of the Interoceanic Highway, Showing Deforestation and Mercury Pollution}

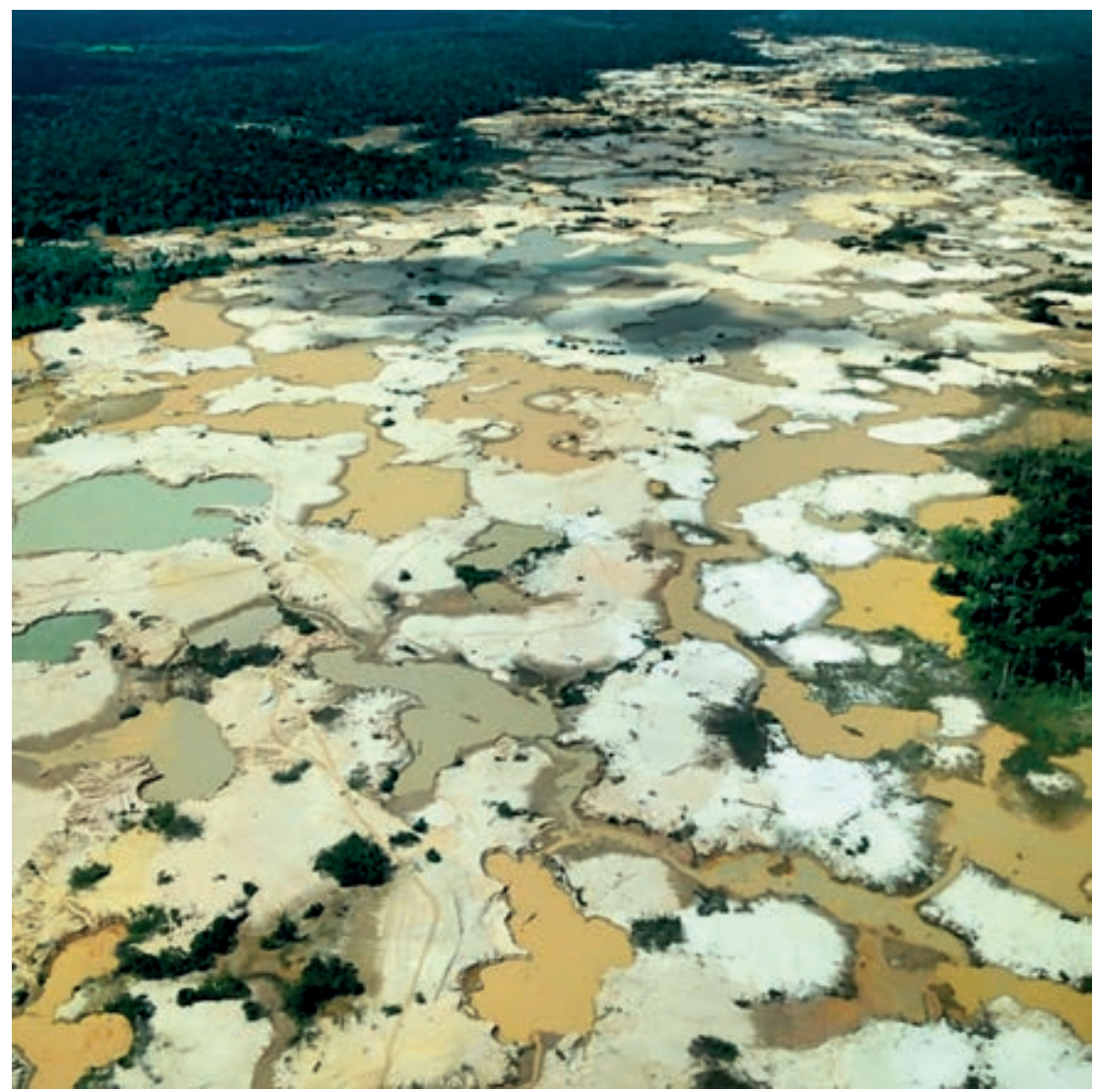

Photo: Vanessa Romo. Mongabay/LATAM, 5 September 2018

In its analysis of deforestation in Madre de Dios department, the Peruvian Government's Supervisory Organism for Forest and Wildlife Resources (OSINFOR) released data on deforestation from gold mining according to forest category. It noted deforestation in ANPs of 91.18 hectares, $0.19 \%$, while in titled native community lands it was 8,236.11 hectares, $17.45 \%$. The greatest areas affected by deforestation were in uncategorized forests, 23,135.51 hectares, 49.03\%; and in forest concessions, $11,532.41$ hectares, $24.44 \%$, while in permanent production forests (PPF) without concessions, the loss was $4,182.54$ hectares, $8.86 \%$.

6. It must be noted that deforestation in both native community lands and forest concessions was largely caused by outsiders with or without mining claims or concessions within community lands or forest concessions, not by the communities or the forest concessionaires themselves. 
Analysis of Deforestation from Mining in Territorial Units of Madre de Dios Department to 2014

\begin{tabular}{|l|c|c|c|}
\hline \multicolumn{1}{|c|}{ Description } & Total Area (Has.) & Deforested Area (Has.) & $\%$ \\
\hline Territorial Reserve & $869,074.34$ & 0.00 & 0.00 \\
\hline Permits on private land & $45,194.39$ & 6.86 & 0.01 \\
\hline Natural Protected Areas & $3,800,493.27$ & 91.18 & 0.19 \\
\hline PPF without concessions & $170,612.41$ & $4,182.54$ & 8.86 \\
\hline Native communities & $398,119.64$ & $8,236.11$ & 17.45 \\
\hline Forestry concessions & $2,505,871.21$ & $11,532.41$ & 24.44 \\
\hline Uncategorized areas & $673,209.49$ & $23,135.51$ & 49.03 \\
\hline Totals & $\mathbf{8 , 4 6 2 , 5 7 4 . 7 6}$ & $\mathbf{4 7 , 1 8 9 . 3 3}$ & $\mathbf{1 0 0 . 0 0}$ \\
\hline
\end{tabular}

Data from OSINFOR-SISFOR, 2015, reproduced in Candia Di Paz and Janampa Felices, 2016b, p. 62.

Another analysis based on LANDSAT images compares deforestation in the districts of Huepetuhe ${ }^{7}$ (Manu Province) and Inambari (Tambopata Province), where the mining zones of Wepetwe, Delta Uno and Malinowski are located. The following chart presents a summary from that analysis.

\section{Deforestation from Gold Mining by District}

\begin{tabular}{|l|c|c|c|c|}
\hline District & $\begin{array}{c}\text { Deforestation } \\
\text { from Agriculture } \\
\text { (Ha.) }\end{array}$ & $\begin{array}{c}\text { Deforestation } \\
\text { from Mining } \\
\text { (Ha.) }\end{array}$ & $\begin{array}{c}\text { Urban Areas } \\
\text { (Ha.) }\end{array}$ & $\begin{array}{c}\text { Total } \\
\text { Deforestation } \\
\text { (Ha.) }\end{array}$ \\
\hline Huepetuhe & $1,972.64$ & $13,541.66$ & 113.85 & $15,631.15$ \\
\hline Inambari & $19,773.92$ & $4,907.13$ & 44.99 & $24,725.76$ \\
\hline
\end{tabular}

My elaboration with data from Huayta Vilca and Apaza Quispe 2010, pp. 84-86.

This analysis also reveals the level of mining deforestation in areas with other use rights.

\section{Areas and Percentages of Deforestation from Mining within other Use Rights,} Huepetuhe and Inambari

\begin{tabular}{|l|c|c|}
\hline \multicolumn{1}{|c|}{ Use Rights } & Deforested Area (Ha.) & Percentage (\%) \\
\hline Native communities & $1,458.64$ & 20.43 \\
\hline Reforestation concessions & $2,266.42$ & 31.74 \\
\hline
\end{tabular}

7. Huepetuhe is the official name of the district. However, the author uses the term Wepetwe to refer to the river and the mining zone, in accordance with the Ministry of Education's approved alphabet and correct transcription in the Harakbut language. 


\begin{tabular}{|l|c|c|}
\hline Forestry Concessions & $1,049.33$ & 14.70 \\
\hline Agricultural lands & $2,365.90$ & 33.13 \\
\hline Total & $\mathbf{7 , 1 3 9 . 9 0}$ & $\mathbf{1 0 0 . 0 0}$ \\
\hline
\end{tabular}

Reproduced from Huayta Vilca and Apaza Quispe, 2010, p. 87

\section{Deforestation Hot Spots in Madre de Dios}

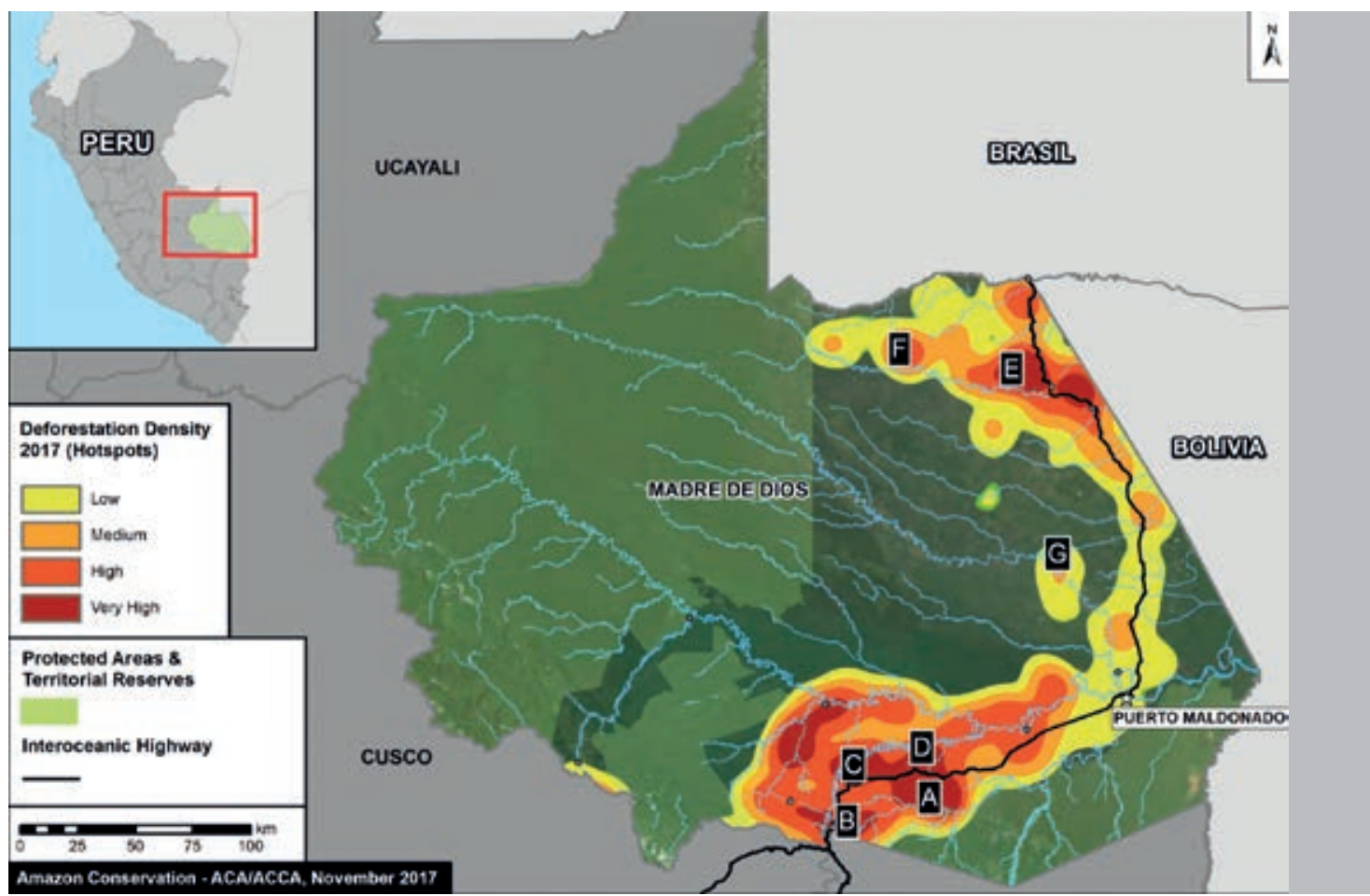

Source: ACCA-MAAP, 2017 Image No. 75. https://maaproject.org/2017/mdd_pope/.

Hot spots A, B, C, and D reflect deforestation from gold mining. Hot spot E shows deforestation from small scale monoculture agriculture, specifically papaya, cacao, and pasture for cattle. Hot spot $\mathrm{F}$ shows deforestation from logging roads within a timber concession. Hot spot $\mathrm{G}$ shows deforestation from cacao plantation and cattle pasture within ecotourism concessions (Finer, Novoa, García 2017).

\section{Agriculture, Livestock, and Agroindustry}

According to the IV National Agricultural and Livestock Census of 2012, the total area of land under cultivation in Madre de Dios department was 68,900.78 hectares, while an additional 30,133.54 hectares were planted with pasture. Both activities 
occur mainly along the Interoceanic Highway. Previously, there were farms of as much as 300 hectares, but these have been parceled into smaller units, some as little as three hectares, although most range from 20 to 100 hectares. There are no more recent statistics. The deforested areas are very likely to have increased both from in-migration and from new areas planted in papaya and cacao in Madre de Dios and in coffee in the Puno piedmont.

We have mentioned above the deforestation along the penetration roads into Madre de Dios from Cuzco beginning in the 1960s. A 2014 analysis by the Madre de Dios Consortium, an international cooperation project led by the University of Florida and including the National Amazonian University of Madre de Dios (UNAMAD) recorded 35,243.49 hectares deforested along the route of the Interoceanic Highway by 1999, when construction of that road had not been completed, and which did not include areas subsequently occupied by informal gold miners. Deforestation in the same area had reached 77,684.75 hectares by 2013, when the La Pampa and Guacamayo mining operations were already underway. Most of the deforestation caused by gold mining was in the stretch between Puerto Maldonado and the Inambari Bridge. Another critical factor was the clearing of forest for papaya and cacao, mainly between Puerto Maldonado and Iñapari, farther north. The following chart presents the analysis of deforestation along the Interoceanic Highway carried out by the Madre de Dios Consortium between 1999 and 2013.

\section{Deforestation along the Interoceanic Highway}

\begin{tabular}{|c|c|c|}
\hline Year & Standing Forest Area (Ha.) & Deforested (Ha.) \\
\hline 1999 & $1,480,516.20$ & $32,243.49$ \\
\hline 2008 & $1,457,169.27$ & $55,590.42$ \\
\hline 2011 & $1,443,892.10$ & $68,867.60$ \\
\hline 2013 & $1,435,074.95$ & $77,684.74$ \\
\hline
\end{tabular}

Reproduced from Dueñas Linares, 2017, plate 16.

\section{New Crops}

Traditional crops in Madre de Dios have been rice, yellow corn, plantains, and manioc, as well as some permanent crops such as citrus fruits. Coffee has long been cultivated in the San Juan del Oro area on the upper Tambopata River, in Sandia Province, Puno, and in recent decades prize-winning gourmet varieties of coffee have been exported from that area, although it yield has declined because of yellow rust. With the opening of the Interoceanic Highway, there has been an influx of farmers from other parts of Peru, especially Ucayali, San Martin, Loreto, and Junín, who have begun producing papaya and cacao for the national market.

The Amazon Conservation Association (ACCA) has been conducting its MAAP Project for several years now, and it is yielding impressive information on 
deforestation. It documented 204 hectares of forest lost to papaya cultivation along the Interoceanic Highway between 2014 and 2015 (Finer et al., 2016). Given that papaya monoculture began to increase several years before 2014 and continues, and that we are also aware of increased papaya cultivation along the Madre de Dios and Las Piedras Rivers, as well as the Interoceanic Highway, the threat of deforestation from this source is likely much greater than has been reported until now (See deforestation hotspots E, F, and G in MAAP image above).

Another crop that is increasingly being cultivated in Madre de Dios is sacha inti (Plukenetta volubili). Although we lack data on areas deforested for this purpose, it is yet another example of development planning in response to ephemeral markets rather than sustainable production options.

Currently, the Ministry of Agriculture and Irrigation (MINAGRI) is promoting the Sierra and Selva Exporting program with the support of the Ministry of the Environment (MINAM) with funding from the Andean Development Bank (CAF). This program is sponsoring cacao cooperatives with organic certification to increase value added to the product. Among the beneficiaries is the San Francisco Association in the Las Piedras District of Tambopata Province, which began production with 30 hectares of cacao and is projecting 100 hectares. So far little deforestation from this operation is evident, since most of the affected area is of secondary forest. However, if it expands rapidly without proper control, this activity would likely occasion far greater deforestation.

Interestingly, deforestation for palm oil plantations, which has been a major problem in Ucayali, Loreto and the Central Selva of Peru is not yet a major factor in Madre de Dios.

\section{Coca Cultivation}

The area of greatest coca cultivation in the Madre de Dios Basin is along the upper reaches of the Inambari and Tambopata Rivers in Puno. In an area near San Juan del Oro, the Peruvian Air Force used SPOT 6/7 satellite images with spatial resolution of 1.5 meters and detected 5,310 hectares of coca plantation between August and November 2017, an increase of 26\% over the 2016 figures, and $6 \%$ of the national total coca cultivation. Of this total, 669 hectares is in the buffer zone of the BSNP (UNODC 2018: 31). This is the same area that produces the gourmet varieties of coffee, affected by yellow rust in recent years. It is also an area of illegal gold mining.

In the San Gabán area near the boundary between Puno, Madre de Dios, and Cusco, 1,296 hectares of coca were recorded in 2017, an increase of $226 \%$ over 2016, and $1 \%$ of the national total (UNODC 2018: 54). In this area there is an obvious association of coca cultivation with illegal gold mining and timber extraction, in proximity to both the Interoceanic Highway and the BSNP.

The other area with coca cultivation in the Madre de Dios Basin is the Q'osñipata Valley with 1,550 hectares in 2018, an increase of $3 \%$ over 2016. Of the total 
area of coca cultivation in the Q'osñipata Valley, 1,074 hectares is in the buffer zones of the MNP and ACR and 11 hectares in native communities (UNODC 2018: 4243). This coca cultivation area includes Gamitana, north of the Carbón River and within Madre de Dios department. To be sure, a part of the coca production in the Q'osñipata Valley is produced legally and sold to the National Coca Enterprise (ENACOCA), but most goes onto the illegal market.

These areas of commercial coca plantation are within the historical territory of the Harakbut. There are no indications of interest in commercial coca production on the part of the communities affiliated with FENAMAD. Some of the first peoples of Madre de Dios cultivate small quantities of coca leaf for medicinal and ritual purposes since ancient times. They have a few plants near their homes that produce no deforestation since they are in small quantities within clearings already made for their homes and gardens. The principal deforestation threat is of large-scale coca cultivation for commercial markets that occupy areas too large to allow forest recovery.

\section{San Gabán Sector, Puno with Areas of Coca Cultivation and Tailings from Gold Mining, 2013}

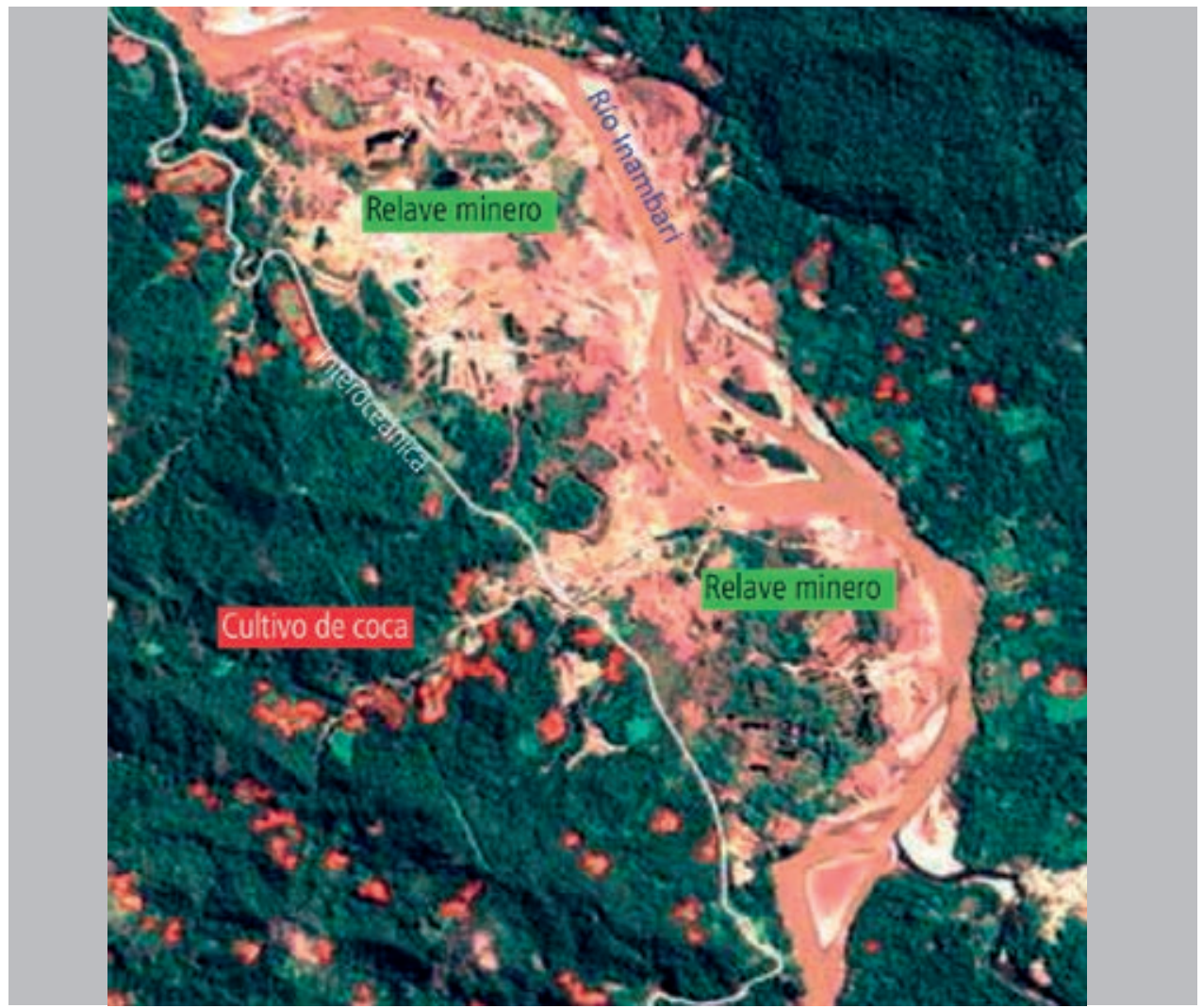

Source: UNODC, 2014, p. 49. 


\section{Forest Extraction}

Unlike the rest of the Peruvian Amazon, the Madre de Dios Basin holds important areas of commercial non-timber forest products, particularly Brazil nuts (Bertholletia excelsa) and rubber (Hevea brasiliensis). The principal obstacle to their orderly management is the superposition of rights for agricultural production; timber, Brazil nut and rubber concessions; mining claims, and first peoples' lands, in areas outside the NPAs.

\section{Rubber}

Since the 1940s, the area of the Madre de Dios Basin where rubber is harvested is Tahuamanu Province, between the Manuripe and Acre Rivers on the Brazilian and Bolivian borders, where 1,147,462 785 hectares of forest contain an average of 2.5 rubber trees per hectare (Álvarez Gómez, Ríos Torres, 2009: 20). This extractive activity had Peruvian Government support through subsidies from the Agrarian Bank and the Madre de Dios Special Project until the early 1990s when the Fujimori Government closed the Agrarian Bank and re-oriented the Special Project's program. With the subsidies eliminated and lower global market prices for the latex, rubber production declined substantially. Today, some local farmers and loggers market limited quantities of rubber in Brazil, where the price is still subsidized, but it is not recorded in Peruvian production statistics.

Among the historic rubber producers in Madre de Dios are the Yine people of the Bélgica and Nueva Oceania Native Communities. Bélgica now has a contract with the Maderysa timber company for timber extraction within rubber producing community forest, where the rubber is not currently being tapped, but left to recover strength until the price improves. For a time during the early 2000s, Bélgica's timber production had support from the World Wildlife Fund (WWF), but that support has been discontinued, and the community harvests certified wood with Maderysa.

\section{Brazil nuts}

The distribution of Brazil nuts in Madre de Dios is shown on the map below, prepared by the International Center for Forestry Research (CIFOR). The principle problem that affects standing Brazil nut forests is the superposition of rights that grant concessions for agriculture, timber extraction, Brazil nut extraction and, potentially rubber extraction over the same territory, pursuant to existing legislation (Chávez et al., 2012). When the owner of the superimposed rights is the same person, there is no conflict and potentially no major deforestation if management is appropriate, but when different people own these rights with no regard for the other resources, there is, and it is often accompanied by violence, as well as deforestation. 


\section{Superimposed Access Rights for Brazil nut, timber, agriculture, mining, indigenous communities, Madre de Dios, Peru}

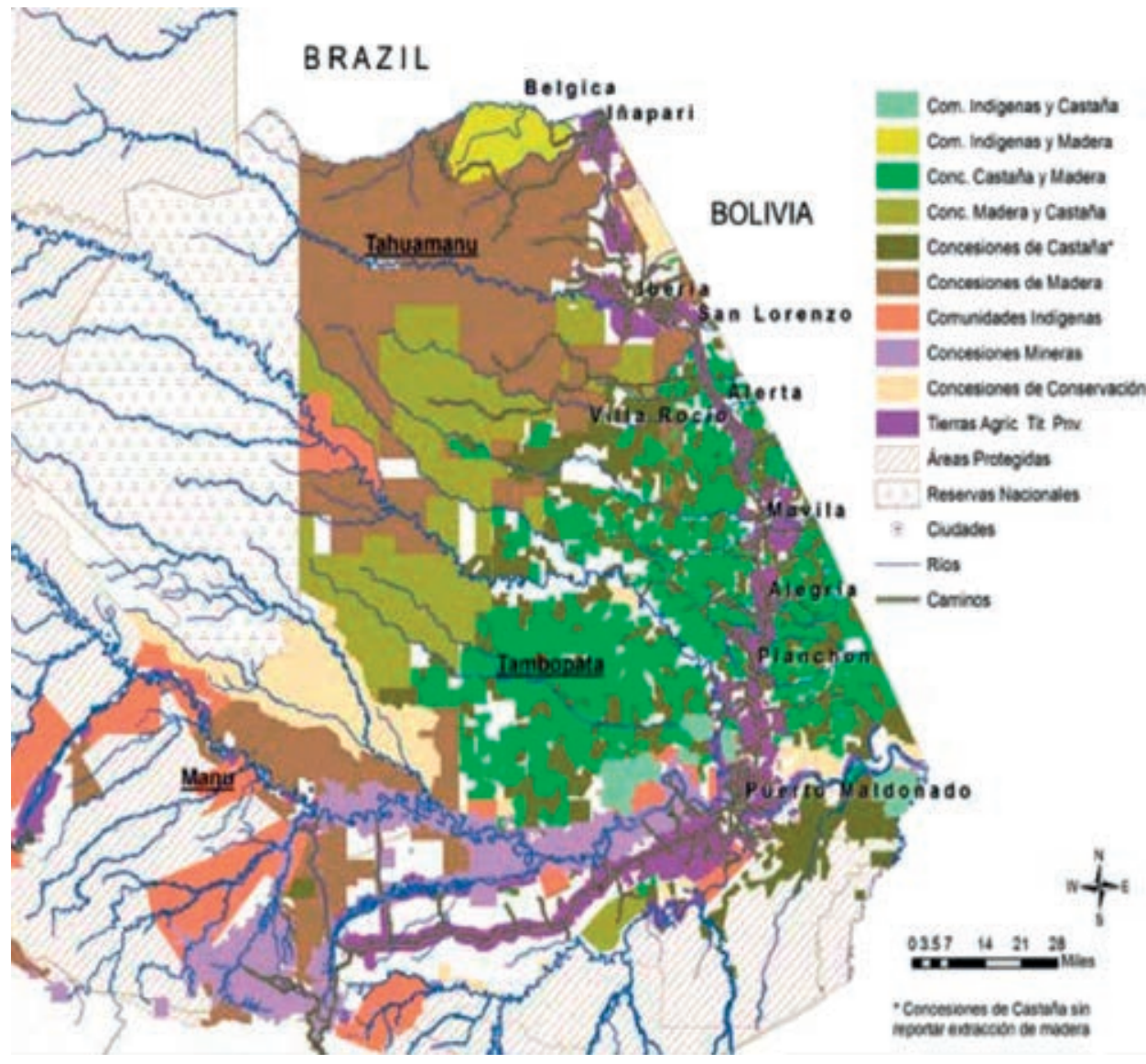

Source: Chávez et al., 2012, p. 6.

The first peoples in Madre de Dios that produce Brazil nuts for the global market are the Ese Eja communities of Infierno, Palma Real, and Sonene; the Shipibo communities of El Pilar, Tres Islas, and San Jacinto; the Yine communities of Santa Teresita, La Victoria, Tipishca, Puerto Nuevo, Monte Salvado, Diamante e Isla de los Valles; the Harakbut communities of Boca del Inambari, San José del Karene, Masenawa, Boca Ishiri, and Shintuya; and the Matsigenka communities of Shipetiari and Palotoa-Teparo. Their production and marketing is coordinated with the Madre de Dios Indigenous Forestry Association (AFIMAD), a technical branch of FENAMAD. Their forest management is gaining recognition through certifications for sustainable management, organic production, and fair trade. They are faced with competition from better capitalized enterprises that continue traditional forest mismanagement practices that are not sustainable and lead to greater deforestation. 


\section{Timber Extraction}

Historically, timber extraction in the Madre de Dios Basin has been done in small plots by local people resident in the area. The native communities have partnered with temporarily with timber company operators better capitalized than they. The 1975 General Law for Forestry and Wildlife (Decree Law 21147) facilitated this arrangement with an article for exceptional circumstances that allowed timber extraction contracts of up to 1,000 hectares for traditional, local timber extractors, although the law attempted to promote management of larger tracts. The Native Communities Law (Decree Law 22175) of 1978 allows for cession in forestry usufruct over those areas demarcated in favor of the communities that have a use classification of forestry and protection, excluded from their property titles. That arrangement allowed for the traditional partnerships with locally-based traditional loggers. While these partnerships were unequal in terms of economic benefit, the communities receiving less, the limited deforestation that occurred was due to the small scale of the operations.

This situation changed with the Forestry and Wildlife Law of 2000 (Law 27308), approved during the final year of the Fujimori administration, and its successor (Law 29763), approved during the second administration of Alan García, but which went into effect with approval of its four regulations in 2015, during the Ollanta Humala administration.

The first of these laws (27308) was promoted by the National Forestry Chamber and some conservation NGOs ${ }^{8}$. It allowed for Ministerial Resolution No. 1351-2001-AG, which established Permanent Production Forests throughout the Amazon Basin, based on macro-use classification, over 24,586,458 hectares of forest of which 2,522,144 hectares were in Madre de Dios (Galarza, Serna 2005: 466). Between 2001 and 2003, 82 large-scale industrial timber concessions of 5,000 to 50,000 hectares over a total of 1,248,037 hectares were authorized (SERFOR, 2013) ${ }^{9}$ with management plans, which were never properly supervised.

Among these concessions, those in Madre de Dios covered the greatest portion of Tambopata and Tahuamanu provinces, not already declared NPAs or native community lands. Not only did the logging roads built within these concessions lead to deforestation for papaya and cacao plantations and for pasture for cattle, but they also blocked titling of native community lands that had not yet been completed when this law went into effect (See hot spots F and G in MAAP deforestation map above).

This law also theoretically allowed for forest protection in private conservation reserves, new roads into the area of the Las Piedras River also facilitated deforestation for papaya and cattle pasture in these reserves (See hot spot $G$ in MAAP image above). But the principal impact of the 2000 law was to facilitate ac

8. See my critique of early proposals for this law, (Moore 1992).

9. This source, accessed on 18 August 2017 has since been removed from the SERFOR website, probably because the data are not current. 
cess to previously inaccessible forest by the concessionaires, who, far from complying with their management plans, began selective clear cutting of forests containing the most valuable species, mahogany and tropical cedar, which were quickly eliminated from these areas. Moreover, loggers operating in these concessions had a number of violent encounters with isolated indigenous peoples on the upper Las Piedras and Tahuamanu Rivers, near the Monte Salvado, Puerto Nuevo, and Nueva Oceania communities of Yine people, while Nueva Oceania has not been able to obtain title to its lands because of superposition by a timber concession.

The devastation of the last stands of mahogany was belatedly slowed when this species was included in Appendix II of the Convention on International Trade of Endangered Species (CITES), beginning in 2004, so that its exportation could only occur in areas with certified management. Another partially effective control was the establishment in 2002 of the MDRT under the Toledo administration to provide some protection to isolated first peoples. This reserve abuts the MNP, the UPNP, and the titled lands of the Yine community of Monte Salvado. However, in 2014, isolated Mashko Piro moved into areas of timber concessions and also of the Monte Salvado and Puerto Nuevo lands, leading to a proposal, not yet approved, for extension of the MDRT beyond its eastern boundary and its reclassification as an Indigenous Reserve, according to the 2006 Law for Indigenous Peoples in Isolation and Initial Contact (Law 28736) of 2006.

In 2009, the Government of Peru approved the new Forestry and Wildlife Law (Law 29763) which sought to correct some of the limitations and errors of the 2000 law; it only went into effect in 2015, once its four major regulations were approved. This Law was prepared by the National Forestry Service (SERFOR) in close coordination with the elite members of the National Forestry Chamber and the Exporters Association (ADEX). In developing it, SERFOR purportedly conducted a participatory consultation process, including representatives of native communities and other local stakeholders that it chose. There is no evidence that these indigenous and other local stakeholders' positions were, in fact, taken into account by the framers of this Law.

Like its predecessor, it also authorizes timber extraction concessions of 5000 to 40,000 hectares for renewable periods of 40 years. No provisions were made to accommodate small-scale locally-based traditional timber harvesters, and one of the four regulations applies to native communities, imposing on them burdensome, technocratic procedures that they are unable to meet, including the hiring of a professional forester to supervise their timber extraction operations, and legal and accounting procedures that go far beyond their capability, which, if not met, put in risk their forestry use concessions. Thus, this law limits their autonomy in internal economic matters that was guaranteed by the Native Communities Law and subjects both the communities and other traditional local loggers to unequal and unjust partnerships with timber extraction companies that have the necessary capital and staff to meet these requirements. 
The problem of sectorization and fragmentation of use rights remains as before, and the Government clearly prefers not to annul previously awarded private property-like rights nor to take seriously and strategically the need for an orderly process of defining land use and development priorities. This confusion responds only to market forces that prefer uniform mass production for short-term profit over long-term sustainable natural resource use. It continues to provide incentives for deforestation and environmental degradation leading to a loss of habitats and livelihood for first peoples and many other local residents.

\section{Oil and Gas Development}

The Madre de Dios Basin abuts the Urubamba Basin in Cusco and Ucayali, where the Camisea gas reserves, among the world's largest, are located. Thus Madre de Dios has long been a major target of companies that hope to find oil or gas there. In 1968, for example, International Petroleum Company (IPC), a Standard Oil of New Jersey subsidiary, had geologists exploring in the area that is now the MNP. when a conflict arose between soldiers accompanying the geologists and isolated peoples referred to in the Lima press as "Amahuaca", probably Mashko Piro, on the Manu River, leaving several of the isolated first peoples dead. Later that year, IPC was nationalized by the Government of Juan Velasco, and in 1973, the MNP was created, thus terminating oil and gas exploration in that immediate area.

Between 1973 and 1975, a US-based firm Cities Services, with its Japanese partner, Andes Petroleum Corporation, operated what was then Block 48 for oil and gas exploration. Their seismic and supply crews had confrontations with the Harakbut peoples in the village then known as Puerto Alegre, now the Puerto Luz Native Community, and in which had not yet been recognized as such, and in Shintuya, as the oil workers aggressively advanced seismic lines and established supply camps in these communities of traditional Harakbut territory. Professional hunters were engaged to provide meat for the oil workers, leaving the supply of wild game heavily depleted. The seismic lines opened access to furtive hunters, loggers, and gold miners, who then invades Harakbut territory once the oil company withdrew (Moore 1981: 140-142). This experience was an important factor inspiring the Harakbut to organize FENAMAD.

A decade later, between 1994 and 1996, Mobil Exploration and Producing International (MEPPI-Peru), with its partners Elf Aquitaine and Exxon Corporation, obtained contracts to explore for oil and gas in Blocks 77 and 78 in Madre de Dios. Block 77 was in an area of northwestern Madre de Dios with presences of isolated Mashko Piro and Yora first peoples, where MEPPI reported at least one sighting of these people. Following a preliminary environmental impact assessment (EIA) and a geological assessment, MEPPI opted to withdraw from this Block covering an area that is now mostly within the MDTR set up to protect these isolated first peoples. 


\section{Areas of the new oil Blocks in Madre de Dios}

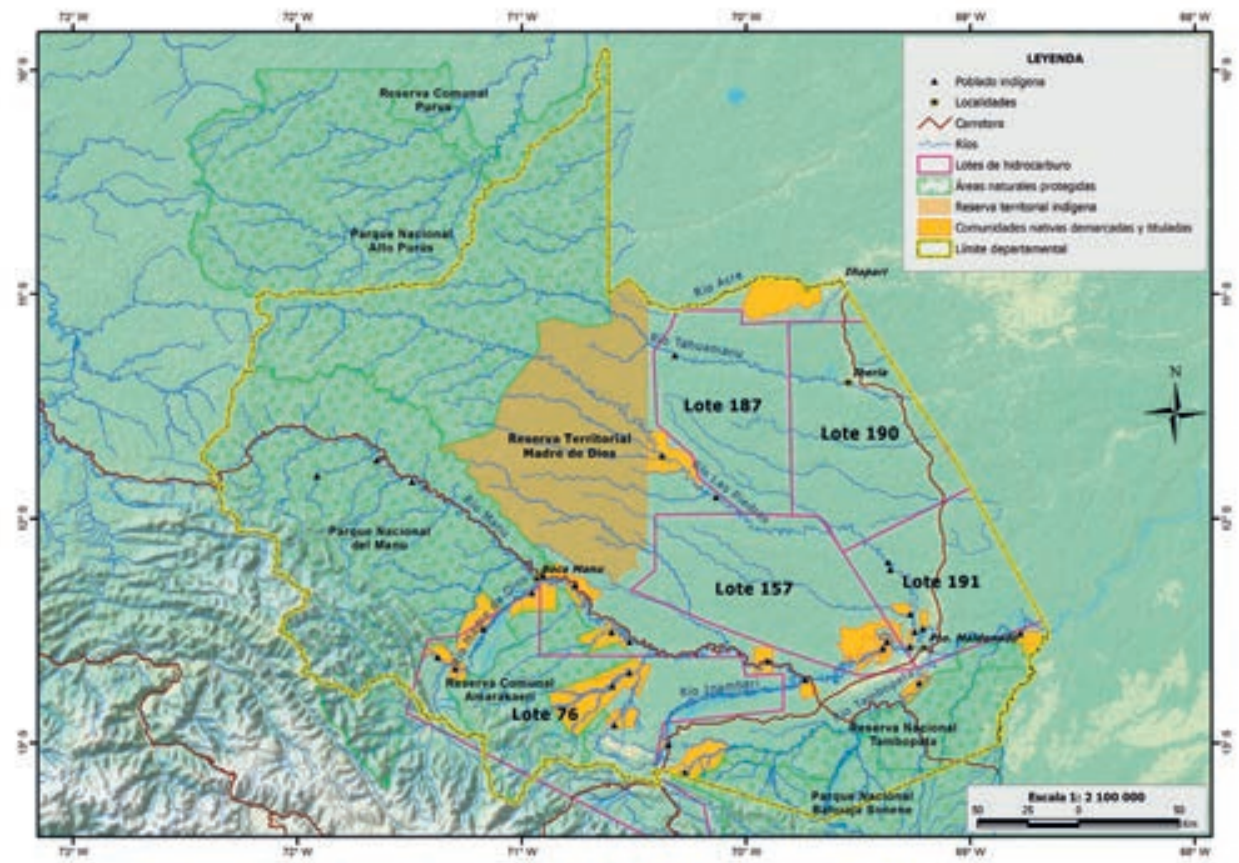

Source: Map prepared by Instituto del Bien Común, based on the Asociación de Conservación de la Cuenca Amazónica (ACCA).

Block 78, farther south covered 1,743,000 hectares in the same area previously explored by Cities Service and which included parts of what are now the ACR, the TNR and the BSNP. Following more sensitive policies toward first peoples, MEPPI had a more or less continuous dialogue with FENAMAD and the local communities of the area, during the process of running six 2-D seismic lines and later additional 3-D seismic lines (Moore 1996: 72-76). Because of this dialogue and support for community members participation in their monitoring process, MEPPI left behind a less problematic footprint when it withdrew from the western part of this Block in 1996. In 1998 and 1999, they drilled one well in three sections in the Inambari Valley of Puno, where they discovered natural gas deposits called the Candamo Reserves, where samples yielded 3.6, 3.0, and 3.7 billion cubic feet of natural gas per day, respectively with total reserves estimated at 42 billion cubic feet of gas (SPDA 2009), which MEPPI considered non-commercial; they withdrew completely in 2000.

Interestingly, the parallel initiatives of conservation NGOs and Peru's National Protected Areas Direction, predecessor of SERNANP were held up between the time the studies were conducted, 1992-1994, including a participatory assessment and demarcation of the areas proposed for the TNR and BSNP until they were formally established. The TNR and the southern part of the BSNP were declared in 
1996, once MEPPI had withdrawn from those areas, with the remainder of the BSNP incorporated in 2000, days after MEPPI abandoned its well drilling operations.

Then, in July 2005, the Peruvian Government, through its oil and gas contracting company, Perupetro, awarded a contract to Hunt Oil Company of Dallas, Texas, in the United States to develop oil and gas in what was then designated Block 76. This block covers much of the same area where previously Cities Service and Mobil had been active, and which included areas of the current ACR, TNR, BSNP, and of the titled lands of the Puerto Luz, Barranco Chico, Arasaeri, and Shintuya native communities.

According to the geological studies conducted for this contract, Block 76 may contain reserves of 8.7 trillion cubic feet of natural gas. Hunt committed to invest up to US\$745 million to develop these reserves.

Hunt is a privately held company that is not subject to the requirements for transparency that apply to publicly traded corporate entities. Initially, FENAMAD demanded consultation and free, prior, and informed consent to Hunt's operations, in accordance with the terms of the International Labor Organization's (ILO) Convention, to which Peru is a signatory and which has been in effect since 1995. Both Hunt Oil and the MEM claimed that this provision of Convention 169 did not apply, since the contract with Hunt in 2005 preceded the Prior Consultation Law (Law 29785) of 2011, which implemented that aspect of Convention 169. FENAMAD challenged this interpretation with a constitutional protection action, still unresolved in Peru's Constitutional Tribunal.

From the time Hunt Oil arrived in Madre de Dios, in 2007, their community relations officer began contacts with FENAMAD, its affiliated organization in the upper Madre de Dios area, the Harakbut, Yine and Matsigenka Council (COHARYIMA), and the principal communities of first peoples in the area of impact of their operations in Block 76 in efforts to divide the communities from their organizations. She offered employment to some of the community fuel to run community electric generators, and some corrugated metal for roofing to individual families. Although Hunt was unable to reach any sort of authorization agreement with FENAMAD, they did sign contracts with minority factions in some of the communities in exchange for the gifts offered, when no quorum was reached in community assemblies. Meanwhile FENAMAD conducted a media campaign denouncing Hunt's activities and pursued legal action in an attempt to block their program of oil and gas development in the ACR.

Hunt established its principal base of operations in the town of Quincemil, in Cusco, at a distance of some 15 kilometers from the nearest Arakbut community, Puerto Luz. They conducted 2-D and 3-D seismic lines, bringing in supplies and equipment by helicopter and planned to drill eight wells within the ACR in coordination with SERNANP, but not with FENAMAD nor COHARYIMA. They were unable to complete even the first well, because of geological obstacles; so, they requested a force majeure extension of the exploration phase of their contract for three 
additional years, but attempted to drill no new wells during this extension. Finally, Hunt Oil withdrew completely from this contract in June 2017, leaving Perupetro with the option of awarding a new contract over this Block.

Complementing Block 76 with Hunt Oil, in 2005, Perupetro awarded two additional contracts for oil and gas development in northern Madre de Dios, Blocks 111 and 113 to Sapet Producing Peru, a subsidiary of China National Oil Company. Following an EIA and negotiations with FENAMAD, Sapet agreed to request of Perupetro exclusion from Block 113 of the areas of the MDTR and the demarcated lands of the Monte Salvado and Puerto Nuevo communities of the Yine people and from the territories of all of the first peoples communities in Block 111 (Servindi 2006). Then, with limited geological and seismic exploration, Sapet released both blocks in 2007, which are no long open to bidding.

However, in 2013 Perupetro demarcated four new blocks in Madre de Dios, numbered 156. 187. 190, and 191, for public tender (Perupetro 2013) and conducted something they called prior consultation with local communities, although there were no agreements or consent on the part of the communities in the area of these blocks, and FENAMAD made some serious observation to which Perupetro has not responded satisfactorily. No contracts for these blocks have not yet been awarded mainly because there has been no expression of interest from potential bidders.

Blocks 157, 187, 190, 191 in Madre de Dios

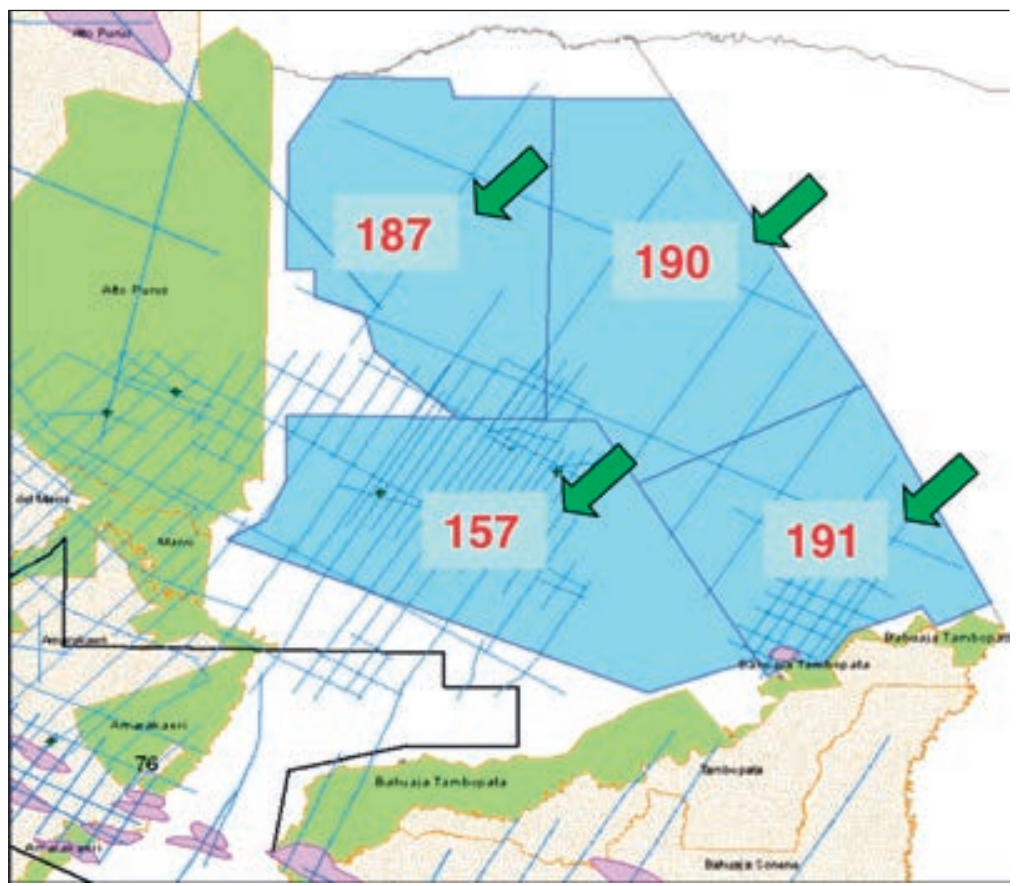

Source: PeruPetro, 2013. 


\section{The Inambari Hydroelectric Dam Project}

In January 2011, following an agreement with the Government of Brazil, the Peruvian Government of the second administration of Alan García issued a series of "urgent decrees" to provide incentives for private sector investment in hydroelectric projects including a 2000 megavolt dam on the Inambari River, having a projected cost of US $\$ 4,847$ million. It would include 810 kilometers of transmission lines to carry the electricity generated there to the Brazilian state of Rondonia, since southern Peru already supplies its electricity needs from other hydroelectric plants. This was to be the largest dam ever constructed in Peru.

The multiple impacts of this megaproject have been analyzed in detail by Serra Vega (2010); Serra Vega, Malky, Reid (2012); Barthem et al., (2016), and Fosberg et al., (2017). It would be located at a point of the Inambari River just upstream of its confluence with the Arasa River, near the boundaries of Puno, Madre de Dios, and Cusco. It would flood an area of $378 \mathrm{~km}^{2}$ with the loss of 308,000 hectares of mostly primary forest, and require the removal of 65 settlements with a population of 4,000 to 8,000 people, among them gold miners, loggers, colonists, coca growers, and traders. It would also destroy 161 kilometers of the Inter-oceanic Highway, which would have to be relocated and rebuilt.

This project threatens to produce massive amounts of greenhouse gases from the forest areas destroyed and put at serious risk the neighboring NPAs, including the BASNP, the TNR, and the ACR, along with numerous species of flora and fauna. For the first peoples, whose communities lie downstream, the principal impact would be the loss of wild game and fish resources upon which their livelihood depends, as well as contamination of their water sources.

An opposition committee has been formed, including FENAMAD and representatives of most of the local communities and municipalities in the area. The regional governments of Puno, Cusco, and Madre de Dios; AIDESEP, COICA, the College of Engineers, and the Ministry of the Environment have declared their opposition to this project. Since the principal funding source, EletroBras, has withdrawn from the project, it is currently suspended, but it still remains a threat because of the agreement between the Governments of Peru and Brazil and the other vested interests involved.

\section{The Conservation NGOs}

Beginning in the 1980s, several NGOs dedicated to the conservation of biological diversity appeared in the Madre de Dios Basin and began efforts to promote and improve the capacity of the NPAs. Among the first were ProNaturaleza, the Association for the Conservation of the Southern Amazon (ACSS), the Peruvian Association for the Conservation of Nature (APECO), and the Peruvian Society for Environmental Law (SPDA). They were joined in the 1990s by Conservation 
International, the World Wildlife Fund (WWF), the Frankfurt Zoological Society (SZF), the Italian CESVI, the Tambopata Reserve Society (TReeS), while still others followed. Their agenda included important initiatives to expand the areas in the Madre de Dios under protection as NPAs, to raise consciousness among the local population on conservation issues, and to promote nature tourism in the area. It is to their credit that they attained important success in these areas, and it is likely that they played a major role in slowing or mitigating deforestation and improving conservation policies both nationally and locally, and now there are important more recent initiatives engaged in these activities.

As we have seen above, some of the private conservation reserves set aside by conservation NGOs along the Las Piedras River have not been fully capable of preventing deforestation from monoculture of papaya and pasture plantation, but they have helped slow this process by the presence of their conservation initiatives.

At critical times these conservation NGOs have been valuable allies of FENAMAD and the first peoples of the Madre de Dios Basin, although the protected areas they helped establish were indigenous peoples' territories that were never recognized as such and, under rigid State control, they severely restricted first peoples' subsistence and livelihood rights and demonstrated little sensitivity to what should have been options to strengthen first peoples' territorial rights as a more effective conservation measure.

In the 1980s and 1990s important financial resources were available to support these conservation initiatives, but in more recent years these resources became scarcer and some of the conservation NGOs began scrambling for funding for climate-change related project for which financial resources were still available. Since the principal remaining forest in the Madre de Dios Basin that has not been granted in concession to corporate interests or is within NPAs, is in native community territories, the conservation NGOs began seeking alliances with specific communities, FENAMAD, its technical unit the Entity Charged with Administration of the Amarakaeri Communal Reserve (ECA-RCA), and other first peoples' organizations to promote climate change adaptation projects under the Reduction of Emissions from Deforestation and Forest Degradation (REDD+) program sponsored by the Framework Convention on Climate Change (FCCC) and many international cooperation agencies. The interest was to promote a carbon market to slow the deforestation process.

In response, FENAMAD and the national indigenous organization, the Inter-ethnic Association for the Development of the Peruvian Amazon (AIDESEP) developed an alternative strategy called the Amazonian Indigenous Network (RIA) that emphasizes right livelihood or good quality of life (buen vivir in Spanish), that strengthens their collective well-being, instead of the carbon market-based approach of the REDD+ initiatives. Some of the conservation NGOs have responded well through effective alliances with FENAMAD and the other associated first peoples' communities and organizations in the Madre de Dios Basin, but others 
have sought to mask more traditional REDD+ projects as RIA initiative that will likely provoke future conflict and division. The future of first peoples' forests in the Madre de Dios Basin will depend in large part on whether or not the first peoples' communities, FENAMAD, and their NGO allies can successfully advance actual RIA initiatives instead of submitting to the pressures of the market economy.

\section{Conclusions}

From the preceding discussion we can conclude that the principal driver of deforestation in the Madre the Dios Basin is the proliferation of poorly planned, technically unsound, economically unfeasible, and environmentally disastrous roads than have been built and continue to be built in the region in response to short-term private interests that carry political weight but lack long-term strategic democratic planning. The immediate causes of the deforestation resulting from these roads are, first, illegal and informal gold mining, coca cultivation, monoculture agricultural production for regional and global markets, and illegal timber extraction that migrants from other areas of Peru have engaged in following the 2007-2008 economic crisis in the country and the lack of adequate Government planning to prevent such disorderly migration and provide alternative to the migrants.

This situation has been exacerbated by ill-conceived, technocratic, vertically imposed, and inappropriate and excessively sectorized laws and regulations produced by bureaucrats, principally in Lima, who are insensitive to the needs of the people of the region. These legal norms respond to narrow vested interests that seek short-term profits and completely lack long-term strategic planning for sustainable development. The Government's decrees and military and police interventions in attempts to bring order have only made matters worse. New policies, laws, and regulations are urgently needed that reflect the long-term interest of the local population, not those of external markets and the interests of a few investors from the outside world.

For the first peoples, the accompanying deforestation has enclosed their traditional territories, diminished their habitats, food supplies, livelihoods, and overall well-being and quality of life, while it has made them increasingly dependent on the global, extractive economy and alienating labor in unaccustomed productive activities. They are no longer able to subsist from hunting, fishing, gathering, and diversified horticulture that they used to enjoy, increasingly buying nutritiously deficient market products to survive.

When I lived in Puerto Alegre in an area of the current Puerto Luz Native Community and visited all of the other existing harakbut settlements in the region, more than 40 years ago, the forests surrounding their villages were intact, with the exception of the pasture areas around the Shintuya Mission that had been introduced by the Dominican missionaries. Howler monkeys provided a lively concert every night, children were healthy and adults regaled me with stories after dinner 
every evening. We ate wild game or fish from the river nearly every day. Barranco Chico is now mostly a desert, having lost nearly all of its forest to gold miners from the outside. Puerto Luz and San José del Karene have lost much of their forest near the Pukiri River, although these communities have been able to expel most of the gold miners from their territories and slow the advance of forest loss in them.

Now, for hunting, the people have to travel to remote areas of the ACR for many days or weeks at a time; fish in the rivers are contaminated with mercury. To obtain protein, they must buy canned foods, accompanied by noodles in the shops of the Delta Uno mining center. The people feel obligated to work in gold mining or timber extraction in an almost uninterrupted manner to meet increasing monetary needs. The children no longer accompany their mothers to their gardens nor go hunting with their fathers. They are enclosed all day in monolingual schools in Spanish, with curricula they have difficulty understanding, and learn few skills that will allow them to survive in anything approaching harmony with their environment. Health problems are increasing from poor nutrition and their degraded environment. Many young people are migrating to urban areas to look for work. The future is grim and they know it.

\section{BIBLIOGRAPHY}

ACCA (Asociación de Conservación de la Cuenca Amazónica). (2017a). MAAP 2. Patrones y drivers de deforestación en la Amazonía Peruana. https: / / maaproject.org / 2017 / maap-sintesis2/.

ACCA (Asociación de Conservación de la Cuenca Amazónica). (2017b). MAAP 75. Pope to Visit Madre de Dios, Region with Deforestation Crisis (Peru). https: / / maaproject.org / 2017/ mdd_pope/.

ÁLVAREZ Gómez, Luis; Ríos Torres, Sandra. (2009). Evaluación Económica del Aprovechamiento del Jebe Silvestre en Madre de Dios. Peru, Instituto de Investigaciones de la Amazonía Peruana, Avances Económicos No. 2. Iquitos.

ANA (Peru. Autoridad Nacional del Agua). (2010). Estudio Diagnóstico Hidrológico de la Cuenca Madre de Dios. Lima. http: / / www.ana.gob.pe/sites / default / files / publications / files/diagnostico_hidrologico_madre_de_dios_0.pdf.

APPLING, George; Salisbury, David S. (2012). Analysis of the Socio-Environmental Impacts of Amazonian Roads: the Puerto Esperanza to Iñapari Road in Peru. Richmond, VA: University of Richmond, Upper Amazon Conservancy. https://upperamazon.org/ wp-content/ uploads / 2012 / 10/ ApplingSalisbury2012SocioEnvironmentalImpactsOfPurusRoad20120821.pdf

ASNER, Gregory P.; Llactayo, William; Tupayachi, Raúl; RáezLuna, Ernesto. (2013). Elevated rates of gold mining in the Amazon revealed through high-resolution monitoring. Proceedings of the National Academy of Science 110(46): 18454-18459. New York. https:/ / www.ncbi.nlm.nih.gov/pmc/articles/PMC3832012. 
BALLÓN Landa, Alberto. (1917). Los hombres de la selva. Apuntes para un ensayo de sociología aplicada. Tesis doctoral Universidad Nacional Mayor de San Marcos. Lima: La Opinión Nacional.

BARTHEM, Ronaldo; Calle, Isabel; Canas, Carlos; Castillo, Oscar; Fosberg, Bruce; Goulding, Michael; Hick, Carmen; Montoya, Mariana; Mora, Carol; Venticinque, Eduardo. (2016). Inambari: Hacia un enfoque integrado de la gestión de cuencas hidrográficas. Lima: Wildlife Conservation Society. https:/ / es.scribd.com/document/348322302/Inambari-pdf

BRAVO Orellana, Sergio (2013). Carretera Interoceanica Sur del Perú: Retos e Inovación. Bogotá: CAF Banco de .Desarrollo de América Latina. http://publicaciones.caf.com/media/34441/ carretera_interoceanica.pdf.

CANDIA Di Paz, Carlos Rafael; Janampa Felices, Johnn Kinny. (2016a). Análisis de pérdida de cobertura forestal en la zona geográfica de integración fronteriza con los países de Colombia, Brasil y Bolivia, año 2014. Serie B, No. 4. Lima: OSINFOR. https: / / www.osinfor.gob. pe / wp-content/ uploads / 2016/06/ Analisis-deforestacion-fronteras-21-JUNIO.pdf

(2016b). Contribución en el monitoreo de la actividad minera en títulos habilitantes forestales, Año 2014, Departamento de Madre de Dios. Lima: OSINFOR. https: / www.osinfor.gob. pe/wp-content/ uploads/2016/06/ Mineria-Madre-de-Dios-21-de-junio.pdf.

CHÁVEZ, Andrea; Guariguata, Manuel R.; Cronkleton, Peter; Menton, Mary; Capela, Jose Luis; Araujo, Jean-Pierre; Quaedvlieg, Julia (2012). Superposición espacial en la zonificación de bosques en Madre de Dios: Implicacio.nes para la sostenibilidad del recurso castañero. Info Brief No. 58, December, 2012. https:// www.cifor.org/publications/pdf_files/infobrief / 4034-infobrief.pdf.

CHIRIF, Alberto. (2011). Pueblos Indígenas Amazónicos e Industrias Extractivas. Lima: Centro Amazónico de Antropología y Aplicación Práctica, Comisión Episcopal de Acción Social.

CIFOR (Center for International Forestry Research) (2016). Informe Subnacional Región Madre de Dios. Lima: Universidad Nacional Agraria La Molina, Insstituto de la Pequeña Producción Sustentable. http:/ / www.cifor.org/publications/pdf_files/Reports/Regional_ report2016.pdf

DOUROJEANNI, Marc Jean. (2006). Estudio de caso sobre la Carretera Interoceanica en la Amazonia Sur del Peru. Wa.shington: Bank Information Center. https: / www.academia.edu/5674644/ Estudio_de_caso_sobre_la_Carretera_Interoceanica_en_la_Amazonia_Sur_del_peru.

(2013). Misterios de la deforestación en el Perú. Actualidad Ambiental, 14 de agosto de 2013. Lima: SPDA. http: / / www.actualidadambiental.pe/?p=19955

(2015). Los caminos de la destrucción en Madre de Dios: carreteras y el atentado contra áreas protegidas. Actualidad Ambiental, 5 de noviembre de 2015. Lima: SPDA.http: / / www. actualidadambiental.pe $/ \mathrm{p}=33413$.

DUEÑAS Linares, Hugo et al. (2017). Problemática Ambiental de la Región de Madre de Dios desde la Perspectiva de la Universidad. Presentación ante el II Encuentro Nacional de Comités Ambientales Universitarios del Perú. Puerto Maldonado, 20-21 de junio de 2017. Puerto Maldonado: Universidad Nacional Amazónica de Madre de Dios. https:// redambientalinteruniversitaria.files.wordpress.com / 2017 / 07 / 2problemc3a1tica-ambiental-de-la-regic3b3n-de-madre-de-dios-desde-la-perspectiva-de-la-universidad.pdf.

FINER, Matt; Novoa, Sidney; Carrasco Rueda, Farah. (2016). Cultivo de Papaya. Potenial Nuevo Driver de Deforestación en Madre de Dios. MAAP 42. Puerto Maldondo: ACCA. https: / / maaproject.org/2016/ papaya-mdd/.

FOSBERG, Bruce R.; Melack, John M.; Dunne, Thomas; Barthem, Ronald B.; Goulding, Michael; Paiva, Rodrigo C. D.; Sorribas, Mino V.; Silva, Urbano L.; Weisser, Sabine. (2017). 
The potential impact of the new Andean dams on Amazon fluvial ecosystems. Plos One 12(8): e0182254. doi: 10.1371/journal.pone.0182254. https:/ / journals.plos.org/plosone/article?id=10.1371/ journal.pone.0182254.

GALARZA, Elsa; Serna, Karlos. (2005). Las concesiones forestales en el Perú. ¿Cómo hacerlas sostenibles? Lima: Universidad del Pacífico. http:/ / infobosques.com/portal/wp-content/ uploads/2016/03/per1.pdf.

GRAY, Andrew. (1986). And after the Gold Rush ...? Human Rights and Self-Development among the Amarakaeri of Southeastern Peru. IWGIA Document No. 55. Copenhagen. https: / / www.iwgia.org/en/resources / publications/305-books/2635-and-after-the-gold-rush-human-rights-and-self-development-among-the-amarakaeri-of-southeastern-peru.

HASSEL, Jorge von. (1905). Las tribus salvajes de la región amazónica del Perú. Boletín de la Sociedad Geográfica de Lima 17(15): 27-73. Lima.

HUAYTA Vilca, Henry; Apaza Quispe, Yessenia. (2010). Análisis multitemporal de los cambios de cobertura ocasionados por la actividad minería aurífera, mediante la utilización der imágenes del sensor LANDSAT (1976-2009). Distritos de Huepetuhe e Inambari. Floresta Amazónica Puerto Maldonado: UNAMAD. http://revistas.unamad.edu.pe/index.php/ Floresta/article/view/30/20.

MOORE, Thomas. (1981). SIL and a "New-Found" Tribe: the Amarakaeri Experience. In Is God an American? An Anthropological Perspective on the Missionary Work of the Summer Institute of Linguistics, (eds.) Søren Hvalkov, Peter Aaby, pp. 133-143. Copenhagen: IWGIA, Survival International.

(1983). Situación de los nativos frente a la minería aurífera en Madre de Dios. Shupihui 8(28): 413-426. Iquitos: Centro de Estudios Teológicos de la Amazonía.

(1992). Nueva legislación forestal: ¿Manejo de bosques o de capitales? Debate Agrario 15: 15-35. Lima: CEPES.

(1996). La Situación de los Pueblos Indígenas de la Selva Peruana Frente a la Prospección / Explotación de Hidrocarburos y Recursos Minerales en sus Territories. Informe presentado a la Organización Internacional de Trabajo en cumplimiento parcial del Contrato de Colaboración Externa suscrito con el Grupo de Análisis para el Desarrollo (GRADE) en el marco del Proyecto Perú: Pueblos Indígenas de la Amazonía Peruana y Desarrollo Sostenible (TSSI). Diciembre de 1996. Lima.

(2003). La etnografía tradicional arakmbut y la minería aurífera. In Los Pueblos Indígenas de Madre de Dios: Historia, Etnografía y Coyuntura, (eds.) Beatriz Huertas Castillo, Alfredo García Altamirano, pp. 58-90. IWGIA Documento No. 32. Lima.

(2006). Introducción. In Exploraciones por los Ríos del Sur, por William Miller, José Domingo Espinar, Julián Bovo de Revello, Juan Guillermo Nystrom, Hermann Göhring, Nicolás Armentia, (ed.) Alberto Chirif, pp. 15-73. Monumenta Amazónica D-8, Iquitos: CETA.

(2015). Los Harakbut, su Territory y sus Vecinos. Document submitted by FENAMAD to the Constitutional Tribunal of Peru, in Support of its Acción de Amparo against Hunt Oil Co. ODEBRECHT LATININVEST. (2014). Activos. IIRSA Sur. http:/ / www.odebrechtlatinvest. com/activos/iirsa-sur.html.

PACURI Flores, Felipe; Moore, Thomas. (1992). Los conflictos entre mineros auríferos y el pueblo Arakmbut de Madre de Dios, Perú. Puerto Maldonado: Centro Eori de Investigación y Promoción Regional.

PERUPETRO. (2013). Nuevas oportunidades de inversión en el Peru. Lima: PeruPetro. https: / / www.perupetro.com.pe/wps/wcm/ connect/ d0f33be0-9d47-4a75-bc76-b5d- 
5f1aa0966/NOV131031_Presentación+Nuevas+oportunidades+de+inversion+en+el+Peru. pdf?MOD=AJPERES.

RÁEZ Luna, Ernesto. (2013a). Minería aurífera artesanal y en pequeña escala y minería ilegal en el Perú. Presentación a la Reunión del Grupo Especializado sobre Minería Ilegal en los Países Miembros de la OTCA, 29 de octubre de 2013. Lima: MINAM. htrtp:/ / slideplayer. es/slide/ 10991694.

(2013b). Plataformas de colaboración para el control de la minería ilegal y para una MAPE (ASGM) sostenible. Presentación al II Foro Global sobre Minería Aurífera Pequeña y Artesanal. https: / / wedocs.unep.org/handle/20.500.11822/12695?show=full.

ROMO, Vanessa. (2018). Perú: deforestación por minería de oro en Madre de Dios es la más alta en los últimos 32 años. Mongabay Latam 5 de septiembre de 2018. https: / / es.mongabay. com / 2018/09/ peru-deforestacion-mineria-madre-de-dios-mercurio-peces /

SERFOR (Perú. Ministerio del Ambiente, Servicio Forestal y de Fauna Silvestre). (2013). Concesiones Forestales con Fines Maderables por Concurso Público. Lima. http: / / www.serfor. gob.pe/portal/pdf/concesiones/conces_fores_mad_concurso.pdf.

SERRA Vega, José. (2010). Inambari. La urgencia de una discusión: Pros y contras de un proyecto hidroeléctrica. Lima: ProNaturaleza. https: / / es.scribd.com/ document/45068277/ Libro-INAMBARI-la-urgencia-de-una-discusion-seria-y-nacional-Por-Ing-Jose-Serra

SERRA Vega, José; Malky, Alfonso; Reid, John. (2012). Conservación Estratégica: Costos y beneficios del proyecto hidroeléctrica del río Inambari. Conservación Strategy Fund. Documento de Discusión No. 2. Abril 2012. http://www.actualidadambiental.pe/wp-content/ uploads / 2014/03/ Costos-y-Beneficios-Proyecto-de-la-Central-Hidroelectrica-de-Inambari.pdf.

SERVINDI. (2006). Peru. FENAMAD saluda actitud de Sapet, muy distinta del MEM y Perupetro. https: / / www.servindi.org/actualidad/1158.

SIERRA Praeli, Yvette.(2019). Deforestación por minería ilegal alcanza niveles en Perú. Mongabay Latam. Menlo Park, California, 4 de febrero de 2019, https://es.mongabay. com / 2019/02/ peru-deforestacion-mineria-ilegal-niveles-historicos /

SPDA (Sociedad Peruana de Derecho Ambiental). (2009). Proyecto de Ley Candamo. Actualidad Ambiental, Lima, setiembre de 2009. http:/ / www.actualidadambiental.pe/wp-content/uploads/2009/09/proy_ley_candamo.pdf.

(2016). Contraloría: GOREMAD construyó carretera con "impactos ambientales muy altamente significativos. Actualidad Ambiental, 10 de mayo de 2016. https: / / www.actualidadambiental.pe $/ \mathrm{p}=37400$.

SWENSON, Jennifer J.; Carter, Catherine E.; Domec, Jean-Christophe; Delgado, César I. (2011). Gold mining in the Peruvian Amazon: Global Prices, Deforestation, and Mercury Imports. PLoS One 6(4): e18875. Baltimore. https: / / doi.org/10.1371 / journal.pone.0018875.

UNODOC (United Nations Office on Drugs and Crime). (2018). Perú. Monitoreo de Cultivos de Coca, 2017. Lima: UNODOC, DEVIDA. https: / / www.unodc.org/documents / crop-monitoring/Peru/Peru_Monitoreo_de_Cultivos_de_Coca_2017_web.pdf.

VILLALTA, Juan S. (1904). Memoria del comisario de Madre de Dios, don Juan S. Villalta. In Nuevas exploraciones en la hoya del Madre de Dios, pp. 5-25. Peru. Junta de Vías Fluviales. Lima: Carlos Fabbri. 



\section{LA PAMPA, THE HEART OF A MINING MODEL THAT IS DESTROYING THE FORESTS OF MADRE DE DIOS}

\section{Guillermo Reaño}

Two hundred and forty years prior to the start of the Industrial Revolution, towards the end of the 1540s, humankind's environmental impact could already be seen in Latin America.

\section{Historical background}

Recent studies conducted on ice cores from the Quelccaya Ice Cap, in Cusco (the largest glaciated area in the tropics) show that toxic emissions resulting from colonial metallurgy (the start of which dates back to 1537) were already contaminating the Andean atmosphere (Díaz, Arana, Torres and Patrucco, 2006:139).

These studies also show that, in contrast, over the period 1438-1532, the period of Inca domination of the pan-Andean territory, extractive activities in the mythical Tahuantinsuyo -the empire of shimmering gold and major territorial expansion- had had no major effect on the health of la Pachamama (Mother Earth).

A great deal has been written on colonial mining. Suffice to say that the impact the activity had on the Andean population and on the biomass of the recently-conquered Amerindian territory was devastating. In a very short space of time, the intensive use of wood as a fuel destroyed entire forests that had been standing for centuries. Contreras (1982:20) comments that the mining that took over Huancavelica was not only on the point of destroying the region's Polylepis forests but was also endangering the surrounding Stipa ichu grasslands. Wood from the queuna tree and grass from the Andean highlands was used as fuel for the casting work undertaken in the mines' furnaces. Such was the damage that, in 1589, Viceroy Conde del Villar had to issue a regulatory provision on the cutting of $i c h u$ in order to prevent its total extinction from the area surrounding the Santa Barbara mining empire, the largest producer of quicksilver (or mercury) during the colonial period.

There is some consensus among historians who have studied Peru's environmental history, when they assert that colonial bureaucrats were deliberately trying to hide the damage that mining was causing to the health of people living near mining enclaves, and to the land and air where the extractive activity was being conducted. Through the works of Mariano Rivero y Ustariz (1798-1857), an Arequipan scientist who studied the activity in Peru's largest mines, we know of the existence of quicksilver disease; a "disease to which miners succumb [...] caused 
by a sudden change in temperature from hot to cold and also by their continuous use of quicksilver".

We can also note the tragedy of "mercurial vapours", as the eminent Peruvian scientist and priest called the mineralogical studies in our country, intimately linked to the recent history of the region of Madre de Dios. "Historia Ambiental del Perú. Siglos XVII y XIX", a well-documented piece of work on Peru's environmental history, sponsored and published by the Ministry of the Environment in 2016, notes two environmental disasters that occurred in our territory. These could easily be compared to the mercury contamination tragedy that occurred in the 1950s in Minamata, Japan, and which provided the basis for the creation and subsequent approval of an international covenant, protecting human and environmental health from anthropogenic emissions and mercurial releases. The first occurred in 1626 in Villa Rica de Potosí, a town adjacent to the most famous mine of the Peruvian Vice-Royalty: increased rainfall resulted in a flood that dragged 19 tonnes of mercury into the Pilcomayo River. The second took place not long after in the quicksilver warehouses of San Jerónimo de Chincha. On that occasion, some 67 tonnes of mercury waiting to be shipped to Arica for final transportation to the infamous town of Potosí went up in flames.

Oh Peru! Land of metal and melancholy! This line by Federico García Lorca clearly alludes to the territory's mining vocation, the natural resources of which were pillaged during three centuries of colonial domination, while a large part of its population was decimated by the hard labour they were subjected to, in the tunnels and mines of the Andean highlands.

The environmental pollution and destruction of highly valuable ecosystems that this resource extraction model resulted in, undoubtedly favoured the interests of the metropolis, elevating Spain as a global power and spearheading the nascent capitalist system. One question arises in this regard: what was the environmental impact on the unknown Amazon region during these years of mining development with its scant attention to the consequences for the health of humans, forests and the land generally?

Contemporary historical writing has focused on the fact that colonial settlement of the Amazonian plains was distinct in many ways. While the forests of the Peruvian centre and north were the object of continuous exploration during the period of Spanish domination (in most cases resulting in the founding and establishment of important cities), the southern Amazon, i.e. the forested territories of what are now the regions of Cusco, Puno and Madre de Dios, remained relatively safe from the Vice-Royalty's expansion.

Some researchers note that, towards the middle of the $19^{\text {th }}$ century, following failed attempts in previous centuries to explore the immense territory bounded by the Tambopata and Madre de Dios rivers (Pedro de Candia, 1538; Diego Maldonado, 1546; Pedro Álvarez Maldonado, 1567-1569; Domingo Álvarez de Toledo, 
1661; Fray Bartolomé de Jesús Zumaeta, 1677; Francisco Bolognesi, 1859; Landener Gibbon, 1851; Faustino Maldonado, 1860; Clements Markham, 1860), the region remained clearly isolated from its closest urban settlements. Apart from the presence of numerous coca, sugar cane and possibly rice growing-estates in the high forests of Kosñipata, in what is now the Paucartambo province of Cusco, the region remained excluded from the developmentalist forces of the recently inaugurated Republic.

The supply of fine woods, so necessary for the urban growth of the coastal and Andean cities, came from Central America and from colonised areas in the north of the country (Maynas). It was initially the quinine (Cinchona officinalis) market and, later, the ambitious search for new areas of rubber that sparked an interest in conquering the Madre de Dios territory during the second half of the $19^{\text {th }}$ century. Apart from the San Juan del Oro forests, in Carabaya, Puno, an area of much gold mining, the country's official border with respect to the indomitable Amazon remained relatively stable in the sources of the Upper Madre de Dios River, the ancestral territory of the pugnacious Wachipaeris or Chunchos. These warriors were, in the words of Clements Markham, a traveller with a singular interest in the flourishing quinine trade, "savage natives [...] fierce, cruel, evil-faced and invincible, they hate all outsiders to the death and roam the dense forests using impassable trails known only to them, completely naked bearing bows and arrows".

This description was undoubtedly that of a typical representative of the strong and "illustrious" European colonialism current at the time.

It was Governor Ramón Castilla who, when dealing with the complaints of certain sectors of the Cusco business class grouped into the Cusco Philanthropic Society, set aside State funds for the construction and maintenance of the roads that would be needed to trade with such an auspicious region of the country. Markham himself (1830-1910) was unstinting in his praise when he talked of the environment irrigated by the Purús (as the Upper Madre de Dios River was known): "If one day the Purús is fully explored, the effect this would have on industry and Peru's future prospects are incalculable. It would open up a route that would cut the distance to Europe in half; it would avoid the meandering route through the mountains and the long journey around Cape Horn; the variety of products from the mountains and forests of the rich lands of the Incas could be taken to the Old World by a direct and easy route" (Markham, 2001).

Could the English adventurer ever have imagined, in advance of the rampant biopiracy of the next century, that the "abundant products of the Peruvian mountains" to which he referred, when defending the exploration of a region he first toured in 1853, would include rubber, wood, skins, oil, gas and gold dragged from the confines of the Andes along the tributaries of that great river?

The presence of the Dominican missionaries (another important player in northern Amazon colonisation) in the Madre de Dios river basin dates back to the end of the $19^{\text {th }}$ century when their first priests began to travel a region that was suffering great 
violence and social upheaval due to the actions of the rubber tappers who settled in the forests following the arrival of Carlos Fermín Fitzcarrald (1862-1897). The latter represented the epitome of cruelty and indigenous exploitation in the Peruvian forests. The Dominicans founded the first two evangelising missions around 1902 on the south-eastern borders: Chirumbia, in the Upper Urubamba, and Kosñipata, in the Upper Madre de Dios. From these two strategically-located holdings, the Church and its colonising apparatus was to penetrate the confines of the region, founding numerous missions in its wake in the form of indigenous reserves (Manu, Malankiato, Puerto Maldonado, Tahuamanu, Koribeni, Lago Valencia, etc.).

The nefarious period of the rubber boom in Madre de Dios (1900-1940) and its harmful consequences must be taken into account. Firstly, as has already been noted, this was a very specific economic activity, undertaken in collusion with the Peruvian State which resulted in an unprecedented genocide of the region's indigenous population, primarily men and women of the Matsigenka, Aramkbut (now Harakbut) and Ese Eja nations.

Take the case of the Harakbut, for example, a people whose ancestral territories were based in the Amazonian foothills and whose ethnography has been studied by renowned researchers (Gray, Moore, Sueyo). According to reports that bear witness to the demography of the area, there were an estimated 30,000 Harakbut living in the forests of what are now Manu and Paucartambo provinces in the years leading up to the rubber boom in the southern Amazon. By the end of this period, their numbers had been reduced by $90 \%$.

The slavery these people were subjected to and the epidemics caused by forced contact with the rubber workers and other indigenous peoples, who were also brought forcibly from other regions of the Amazon, led the Harakbut to the verge of extinction. The ongoing obstinacy of some groups surviving today to remain in isolation without the contact their forefathers had has much to do with this era.

Ethnocide also meant the loss of these native communities' ancestral territories. For the indigenous peoples - ten in Madre de Dios, according to the Ministry of Culture - territory is vital to satisfy both their physical and spiritual needs. Moore (2013) notes in this respect that "a Harakbut will not touch the forest more than is essential for their needs because animals live in the forests with whom they need to maintain good relations. They will also neither hunt nor fish more than is necessary for their group's survival. Commercial hunting, fishing and the extraction of timber and other forest products are in violation of these principles."

The Harakbut who were able to avoid the holocaust sought refuge in the Dominican missions. Failing this they were forced to live as slaves on the cocoa and sugar estates that the descendants or relatives of the rubber barons established in the region. Moore comments that, in 1935, "the Swedish engineer Sven Ericsson announced a Swedish settlement project in the area of the Karene River and proposed an attack on the Harakbut living there, using tear gas and military force until the indigenous peoples surrendered" (Moore 2013:84). 
Eighty years after Markham's journey through the lands of the Wachipaeris -Harakbut from the Paucartambino district of Kosñipata- the vision of those foreigners who invade their lands has not changed a bit.

Yesica Patiachi is a bilingual teacher from Puerto Luz, one of the eight native communities which, together with the Peruvian State, jointly manages the Amarakaeri Communal Reserve, a protected natural area of 402,335.62 ha. created in 2002 to restore the Harakbut's ancestral territory. She states that her elders - grandparents in colonial language - recalled that the Tayoris, a warriorlike people who came under violent pressure from the rubber tappers, invaded their territories, causing great death among them. "For the Harakbut," comments Patiachi, "Fitzcarrald, discoverer of the isthmus that enabled river access to the Madre de Dios basin from the northern Amazon, caused the greatest genocide of all time: on one day alone, 3,000 Harakbut were murdered, turning the rivers of our territory red" (Pers. comm., 2018).

"In our country's history," notes Mauricio Zavaleta in his introduction to the book on Sontone, "the indigenous Harakbut contacted by Fr. José Álvarez (known as Apaktone) at the end of the 1950s, were private agents, guided by their own commercial or religious interests, and it was they who initially contacted the indigenous peoples of the Amazon, a situation that has not changed to this day".

While ethnocide and hunger were the common denominators of this period, we have to assume that the environmental impact was also severe. In a recent article published in Peru on the Actualidad Ambiental and Solo para Viajeros platforms, Marc Dourojeanni gave no great importance to this possibility stating that, "despite the woeful period of the rubber boom, which did not cause significant deforestation, the Amazonian forests were not only in good condition but had recovered following several centuries of being virtually uninhabited".

Around 1930, small-scale gold mining along the banks of the region's rivers and the extraction of fine woods from its forests became stable and highly prosperous activities in the headwaters of the Madre de Dios River. Mazuko (or Masko Humasuko) was the name given to the Japanese settlement that grew up around the current Inambari bridge over the Southern Interoceanic Highway, with the aim of producing vegetables to sell to the area's miners and loggers.

Like other traders in the area, the venerable Japanese were forced to conduct a large part of their transactions in gold dust, gold leaf or gold nuggets, and it was they who - without knowing it - gave their name to the town of Mazuko, capital of the Inambari gold district, and the municipality in which the La Pampa mining emporium was located.

It was in that same decade that construction began on the Puerto Maldonado-Quincemil road. 
In "Las rutas del oro ilegal", required reading for an understanding of the gold mining dynamic in the Madre de Dios region, Claudia Benavides, the author of the chapter on Peru, states that three gold rushes were to rock the region once the South American rubber boom was over. The first took place in the 1960s when spontaneous groups of Andean settlers colonised the sub-basin of the Colorado River - the Karene to the Harakbut - to extract the precious metal from the area around Puquiri and Huepetuhe. This coincided with the construction of the Cusco-Puerto Maldonado road and the dreams of road integration promoted by President Fernando Belaunde during his first term in office (1963-1968). According to Dourojeanni, he was "the Peruvian leader who caused most harm to the region's natural heritage with his ideas and actions on the unrestricted promotion of roads and their lack of planning across virgin or nearly virgin lands in the Peruvian forest, including the Marginal de la Selva, along with the incentives he provided to settlers without any consideration for the environment" (Dourojeanni 2009:2017).

The second gold boom was in the 1980s and resulted in the arrival of waves of peasants coming largely from Cusco, Puno and the south of the country. They settled in the Malinowski River basin with the aim of mining for gold. The decade that followed coincided with the economic liberalisation policies of President Fujimori's government, whose 1993 Constitution significantly reduced the protection offered to communal lands. Conflicts between miners and native communities multiplied over this period, most often to the detriment of the native populations. Deforestation and environmental damage began to arise due to the lack of State action.

Finally, from 2007 to 2009, during the hike in the international price of gold and a breakdown in subsistence agriculture in the south Andean mountains, a third boom occurred; the consequences of which have yet to be fully felt in the body and soul of the region, sometimes considered Peru's biodiversity capital.

La Pampa, an agro-forestry zone located in the Tambopata National Reserve (RNT) buffer zone which, as of 2007, had shown little indication of any illegal mining activity, was from that year on invaded by thousands of settlers and peasants from the southern mountains when it became common knowledge that there was good quality gold to be found in the area. That year, the price of an ounce of gold, so venerated by the settlers, was USD 250 on the international markets. By 2016 its price had exceeded USD 1,300.

The constant hike in the price of gold made any form of extraction profitable, even if it required removing it from the subsoil of the most remote forests. In this context, Claudia Benavides indicates that Peru became the sixth largest gold producer in the world, with an annual average production of between 160 and 170 tonnes. "Small and artisanal mining," states the researcher, "account for approximately $20 \%$ of national gold production, i.e. around 40 tonnes per year." According to the consultancy firm, Macroconsult, Madre de Dios increased its gold produc- 
tion by 35\% over the 2008-2011 period. Data from the Amazonian Centre for Scientific Innovation (CINCIA) indicates that, in 2008, 2\% of the world's annual gold production came from the "quarries" of Huepetuhe.

Sabina Valdez, head of one of the artisanal mining associations that was operating in the Manuani River area prior to La Pampa's invasion, states the following: "We were living peacefully, extracting gold on a small-scale and with the proper State authorisations, but, one day, illegal miners arrived and everything changed" (Revista Viajeros, 2016). Members of the Manuani River Miners' and Farmers' Association, a collective led by Ms Valdez, immediately alerted State officials to the illegal activities. Their complaints and the approaches they took to the Regional Madre de Dios government and the ministries involved in any possible solution were futile. In small groups or en masse, the illegal miners were, like ants, taking over the best lands and water sources, imposing a kind of occupation based on the strength of their powerful chainsaws and machinery, which were appearing as if by magic.

Soon there were 1,000,10,000 and even more. Huts lined with blue plastic and corrugated iron multiplied; towns, businesses, bars and brothels likewise. A buoyant and highly dynamic parallel economy became established alongside the village of Manuani with other human settlements sprouting between kilometres 98 and 116 of that highway. Law and order began to become the responsibility of the miners themselves.

$* * *$

The legislation approved in Peru from 2012 on, due to the popular unrest in Madre de Dios and the need to formalise the activity in order to combat its ills, clearly sets out the characteristics of illegal and informal mining. Illegal mining is "exercised by private individuals or companies using equipment or machinery that does not suit the nature of the mining activity being undertaken (Small Mining Producer or Artisanal Mining Producer), or does not meet the administrative, technical, social or environmental requirements governing these activities, or is conducted in areas where it is prohibited" (Legislative Decree 1105), such as the Protected Natural Area of the Tambopata National Reserve.

Informal mining, according to the same legislative decree, is the same as the above but may be conducted in areas not prohibited by law.

\section{Journalistic notes}

Saturday 2 March 2019, 4 p.m. Hundreds of people -men, women and childrenare surrounding the Plaza de Armas in Puerto Maldonado, the same square that has since 19 February been closely guarded by police officers from Lima to ensure compliance of SD 028-2019-PCM, which suspends constitutional guarantees in the districts of Tambopata, Inambari, Las Piedras and Laberinto, and Madre de Dios regions, and imposed a state of emergency, the first action outlined by the national government to combat illegal mining in the zone. 
The orders from the high police command were emphatic: the supreme decree repealing paragraphs 9, 11, 12 and 24 of the Political Constitution of Peru for 60 days (relating to the inviolability of domicile and freedom of assembly and movement in the stated districts) had to be strictly complied with.

The situation is extremely tense. A police officer with a set expression is exchanging words with a civilian bearing balloons. By his side, a woman with Andean traits rests a crying baby on her hip.

Suddenly, unexpectedly, a group of workers removes the plastic netting put up months previously to fence off the edges of the historic square during the remodelling works that were to end on this day. The crowd, pushed forward by the momentum, spill over and quickly fill the public space. It has literally been taken by storm. There is an explosive joy among police and settlers alike in becoming the protagonists of a special day, the latter having arrived from all over, even the troubled area of La Pampa.

In Puerto Maldonado, in the midst of a state of emergency, this weekend will be recalled by its inhabitants as the day when the city's main civic space, located on the banks of the Madre de Dios and Tambopata rivers, was reclaimed. No matter that the provincial municipality has suspended this year's festivals because of the state of emergency.

That Saturday, and Sunday 3rd March, Puerto Maldonado's main square and surrounding streets were transformed into a carnival. The god, Momos, had returned. Peace, too, it seemed.

Let's start at the beginning. Mining could be said to make up the DNA of the Madre de Dios region and its people, both in the past and in the mining fever of more recent decades. The regional flag speaks for itself: a green background crossed with a muddy yellow stripe - green for the natural wealth hidden in the sector's forests, and yellow, the colour of the gold that its great rivers drag from the Andean foothills.

The economic projections, too, confirm this: while official figures indicate that mining (illegal, informal and legal) accounts for $41 \%$ of regional GDP, if related activities are included (the sale of fuel, transport, spare parts etc.), this figure reaches in excess of 70\%. It is worth noting that 7 in every 10 soles produced in Madre de Dios are directly or indirectly linked to gold mining (Source: El Comercio, 11/04/2018).

La Pampa is also the capital of an economic activity that involves millions of soles and attracts companies of all persuasions, from the ubiquitous Ferreyros S.A. - which sells its machinery to a buoyant industry from offices in Puerto Maldonado- to the more dubious Backus Corporation. The Frontera Pirata portal has, for some time, focused on prostitution and bulk alcohol sales that surround the beer business in La Pampa; it is, according to the former Minister for the Environment, Fabiola Muñoz, "the place where all of Peru's evils are represented". 
So we are not talking about a mere camp of tin shacks and yellow plastic. In 2016, we interviewed Dr. Guimo Loayza, the Ombudsman for Madre de Dios. What he told us at that time revealed the magnitude of the problem that was brewing: "La Pampa is a free zone; the Ombudsman can only enter when there are interdictions. It is an area outside the law, and all kinds of crimes take place there: rape, extortion, contract killings, theft, human trafficking... And yet, paradoxically, you can obtain all the basic services you need in La Pampa, as well as cable, internet, private schools, night clubs... Five years ago, La Pampa's population was estimated at 30,000, it's more than double that now."

The minister spoke during the first days of the intervention in La Pampa, of 25,000 people living in a slum area which, in fact, had ceased to be an illegal mining enclave in the strict sense of the term, and had become more of a satellite city. This is where the bulk of Tambopata province's voters were now living, where local politicians had become powerful and where transactions for millions upon millions of soles were conducted.

To rectify this mayhem will be a titan task. On the one hand it requires a large injection of police intelligence, and on the other, the setting in motion of a revolution that can enforce new conditions and fundamentally change the correlation of social forces in the region.

In its first report on Operation Mercury 2019 - the name given to the military solution implemented by the central government to evict illegal miners from La Pampa - the Mongabay Latam environmental news agency quoted César Ipenza, environmental lawyer, and Ernesto Ráez, ecologist, both experts on Madre de Dios. Ipenza said, "Operations that only involve the Armed Forces, with the press covering the destruction, do not work." Ráez was more explicit, adding: "Madre de Dios has seen its economy hijacked by this crime [referring to illegal mining] and a healthy economy needs to be rebuilt."

Much of the above could also be seen from the public announcement made by the Apostolic Vicariate of Puerto Maldonado a few days after the start of the operations against illegal mining: "We believe there is a need to be vigilant so that the interventions being carried out in La Pampa do not cause the evil that is being driven out of La Pampa to infect other protected areas such as the Amarakaeri Communal Reserve, farmland or the territories of the Native Communities."

“The State's intervention is not felt here," commented Manolo Ponce de León from Lima and owner of one of the main ice cream parlours in the city, a few days after the start of the operation. "Despite what the media say, this city does not rely on mining: life in Puerto Maldonado is organised around the logging business and the service industry. Mining is focused around Mazuo and areas close to La Pampa as 
well as the so-called mining corridor. Here in Puerto Maldonado, however, we live off timber." (Pers. comm. 4/03/2019.)

The first phase of the police / military interdiction - the barbarism we Peruvians use to represent the actions undertaken to destroy the camps and machinery that feed the cancer of illegal mining - in La Pampa officially ended on 5 March 2019 with an announcement from the Interior Minister, Carlos Morán, speaking from the recently-established Highly Mobile Joint Temporary Base in Camp Alfa. He stated that 51 victims of human trafficking had been rescued and 80 people had been placed under preliminary arrest.

He also told the press that they had seized 203 engines, 76 rafts, 56 dredgers, 132 hoppers, 141 gold burners, 8 chainsaws and 15 vehicles. The government estimated the value of the material seized and destroyed by the security forces at 53,319,322 soles. The operation involved 1,272 police officers, 300 soldiers from the Armed Forces, 70 representatives of the Prosecution Authorities, and forensics and explosives experts.

Minister Morán immediately announced the start of the second phase of the intervention in La Pampa, which seeks to eradicate illegal mining once and for all in the reclaimed territory. This stage, known as consolidation, will last 180 days. In conjunction with this, the environmental recuperation of the degraded area also commenced, which the Minister of the Environment and the President of the Republic himself called the productive reconversion of La Pampa.

Regarding this, Former Minister Muñoz commented: “We are not only reclaiming the principle of authority in La Pampa but are also showing that the productive and sustainable development of Madre de Dios is possible, on the basis of its natural capital, which includes the forest and also mining, where work is being done to legalise this" (Actualidad Ambiental 18/03/2019).

Francisco Román is one of the most knowledgeable Peruvians when it comes to ecological restoration in areas highly degraded by human action. He has been a director of the Centre for Amazonian Scientific Innovation (CINCIA) since 2016, an institution working with miners and municipal authorities in six districts of Cusco and Madre de Dios to clean up the environment. Three of these districts were involved - "interdicted" in the local jargon - in Operation Mercury 2019: Inambari, Laberinto and Tambopata.

Román and his team, comprising technicians from the region, have in recent years been striving to develop an intervention model that can resolve the environmental problems that illegal mining has caused in the region.

CINCIA estimates that 80,000 hectares have been lost throughout Madre de Dios due to mining activity. In the area of La Pampa alone, their figures suggest that 11,000 hectares have been destroyed. 
Demonstration plots that have been established in a geographic arc, stretch from Quincemil district, in Cusco, to the periphery of Puerto Maldonado. The mercury and biocarbon laboratories; the drones monitoring the work from the sky and the high-tech greenhouses that have been implemented with the support of the Inambari municipality, all bear witness to their efforts, and to the achievements CINCIA has made by working in tandem with the population.

In 2016, Dr. Román received the Antonio Brack Egg National Environmental Award for his research into reforestation with native species of areas affected by informal gold mining in Madre de Dios.

Curiously, Dr. Francisco Román was not called on officially, either by the central or regional governments, to give his impressions of what should be done in La Pampa. He has more than enough expertise. His institution did not participate in the implementation of the "Comprehensive Plan to Counter Illegal Mining in Madre de Dios" which the government -14 ministries according to the former Minister of the Environment- brought in from Lima.

"Can the intervention area be restored?" we asked him. "Yes, for sure, the municipality of Inambari has a reforestation project approved by the Ministry of Economy and Finance (MEF) for 19 million soles. It's been kicked to and fro between the different public offices for three years now. This project alone could provide work for very many people." "How many?" we asked. "I don't know," he says, "But I would say around 8,000 days of work." (Pers. comm., 27/02/2019).

President Martín Vizcarra visited zone zero on Friday 22 February 2019. From the auditorium of the Sixth Brigade of the Special Armed Forces, stationed in Puerto Maldonado, he was emphatic: "We are here to stay. The Peruvian State has made a decision that should have been taken long ago. This decision is irreversible. We are not here to enforce the interdiction and then leave. We are here to promote the region's development, not only to act vigorously but also in cooperation with the local and regional authorities to create alternative development." (Actualidad Ambiental 13/03/2019).

Those present, State officials, regional authorities and journalists from Lima and Puerto Maldonado applauded enthusiastically.

The President took the opportunity to symbolically hand over to Benedicta Arcayo, owner of the Nueva Fe mining company, the documents that successfully finalised the formalisation process. President Vizcarra then announced that he would be convening "a working meeting as soon as possible, involving the regional governor of Madre de Dios and the local mayors, in order to establish a regional development plan, with concrete actions that will make development possible."

"Did you participate in the meeting that President Vizcarra organised at the Fuerte Pachacútec military base?" we asked Wuilton Camala, mayor of Inambari district, 
the municipality in which the infamous La Pampa is located. The burgomaster hosted us in Mazuko, the district capital. The day before, 500 demonstrators, all from La Pampa, had surrounded the municipal buildings demanding to be heard. The mayor himself had had to calm them down to prevent matters from escalating. "We were not consulted," he responds with annoyance. In virtually two months of work we have received no official letters or documents aimed at coordinating our action. We know the problems of the district better than anyone, we live here, we could give ideas. We could have provided statistical data on how many people there are, how many jobs created, even information on environmental remediation" (Pers. comm 27/2/2019).

For Camala, an activist from Alliance for Progress (APP) -the political party of the Regional Governor, Luis Hidalgo Okimura- the intervention should have been gradual to avoid affecting the district's economy, which is highly dependent on mining and the economic transactions generated in La Pampa. "Thirty-five thousand people live in this zone; $80 \%$ of the regional economy moves through their human settlements and businesses. We are talking about a territory in which mining, commercial and also farming activities are taking place. The interdiction, the bombardments, are affecting thousands of Inambari residents. Illegal mining needs to stop but we also need to deal with the social and economic problems arising from the intervention."

"Do we want to return this area to what it was before or do we want to convert it into a productive region?" questioned lawyer Fabiola Muñoz, former Minister of the Environment, out loud on the day that Operation Mercury 2019 began.

We asked that question of Tatiana Espinosa, a forestry engineer who has spent many years in Puerto Maldonado and who is executive director of Arbio Perú; an institution that promotes analogous forestry, an ecological restoration tool that generates productive development while respecting the original vocation of the forests and listening to the people they are working with.

Tatiana, the owner of an iconic 916 ha forest concession in which hundreds of shihuahuacos (Dipterix micrantha) are protected -the oldest and most symbolic trees of the Peruvian southern Amazon- falls quiet for a moment and then tells us that she would divide the intervention area into zones so that it could be used for different activities: reforestation, analogous forestation and also, to enable the forest to recover gradually and the biological corridors needed for a genetic interchange of forest species between the Manu National Park, the Tambopata National Reserve and the Bahuaja-Sonene National Park to be restored.

"The main problem with these interventions is the short-sightedness, the hurry involved. Because when you hurry you don't take account of the agroecological system that needs to be implemented and suddenly you are establishing monocrops and using the same old fossil fuels, agrochemicals and pesticides. Just more of the same." (Pers. comm 4/03/2019). 
"Who should lead the intervention?" we asked her. "The National Protected Natural Areas Service, SERNANP, as implied in the executive summary of the 187-page Comprehensive Plan produced by the central government?" "SERNANP is not a production unit; perhaps the Ministry of Agriculture and Irrigation (Minagri) itself or the Ministry of Production," she answers. "Is there the capacity in the region to lead the productive reconversion that the government wants to implement?" we continue. "Of course," she replies. "Work has been ongoing for a while in the Madre de Dios region on environmental restoration programmes. CINCIA, we in Arbio Peru, the Institute for Research into the Peruvian Amazon (IIAP), the Association of Ecological Agriculture in Madre de Dios, have all been doing good work in this regard."

The model exists. The regional humane capital too. Last year Tatiana Espinosa won the Jane Goodall Hope and Inspiration Ranger Award from the International Ranger Federation and the Thin Green Line Foundation for being someone who, despite all the obstacles, had managed to implement conservation actions to protect threatened areas and species. To date, however, Ms Espinosa has not been contacted by the government either to be involved in the intervention project.

Between 2013 and 2016, 109 interdiction actions were conducted in the area, notes Aramís Castro from the Ojo-Público portal, involving an estimated budget of 93 million soles. This is nearly twice what the State will invest in the coming years, as initially stated by former Minister Muñoz. And yet illegal mining has not stopped. Over this same period, mining destroyed 30,500 hectares of forest in Madre de Dios.

In the town of Puerto Maldonado, in Mazuko and also in the criminal area of La Pampa, doubts remain as to the efficacy of Operation Mercury 2019, despite the grandiose media campaign implemented by the government. And yet there is still optimism among the inhabitants. France Cabanillas, a specialist in environmental restoration, summarises the general feeling on social media very well: "I am optimistic and I hope that the strategy that has been commenced will improve. I note the goodwill of the Madre de Dios authorities to listen to the people; this was not the case in the past" (Facebook, 4/03/2019).

"And what do you think?", we asked the woman who could not stop taking photos at one side of the renovated square on the day the public space was liberated by the people of Puerto Maldonado. "There is a crime problem here, thieves have taken over the streets, there are attacks at all hours. Illegal mining? I don't know about that, that's another issue..." (Actualidad Ambiental, 13/3/2019.)

\section{Epilogue}

Víctor Zambrano, President of the Tambopata National Reserve management committee and well-known environmental defender, is an authoritative voice when it comes to illegal mining in the area of La Pampa, Madre de Dios. We visited him at 
the tourist lodge that has been established within the K'erenda Home Private Conservation Area, which has been protected for a number of years.

The second stage of Operation Mercury 2019 will be complete within the next few weeks. Are we in a position to state that this will, at last, be the final battle to rid the area of illegal mining?

My first impression is that this action has been taken with the authority, with the firm hand, that was needed. It has clearly resulted in an initial shake-up of the illegal mining that has done us so much harm. The work being undertaken is not so different from what we were calling for. It is public knowledge that the Tambopata National Reserve management committee were proposing gradual interventions into invaded area. The government, however, opted for an immediate solution, which we of course supported.

Critics of the measure use the failure of previous bans to suggest that this could suffer the same fate. What do you think?

It's clear that whenever operations have been conducted on this scale in the past, very little progress has been made: they were shining examples of interventions from a journalistic point of view but no more. The security forces would stay five days, maybe a week, and then leave. This is what we did not want to happen this time and we can, in fact, see the strength and determination of those implementing the new strategy.

Your management committee has been one of the loudest voices in demanding firm intervention in this regard, isn't that right?

We have been calling for this action for the last nine or ten years and so we support it. It has taken three governments for a firm decision to finally be taken. Three governments and a high cost, which has been paid by our environmental defenders. But we did more than make demands: we submitted proposals, we repeatedly proposed alternative solutions to this problem.

What needs to be done now?

Our position is clear and we make this known to the State at every opportunity: once the zone has been recovered from illegal miners, and this involves a territory that could cover between 8,500 and 15,000 hectares, it has to be given a clear status, a status that will enable an authority to be appointed with responsibility for it. It is obvious to us that the current so-called buffer zones have no specific purpose, and there is no effective authority with responsibility for them. The theory, the technical rules, say much about these zones but, in practice, they have been left to go to ruin; people can do what they want in the buffer zones and nobody takes responsibility. 
Let me ask you a very concrete question. Who was occupying the area that is being recovered prior to the mining invasion?

Largely peasant farmers sanctioned by the State and invaded by illegal mining. I would like to come back to this point in a moment. Prior to the invasion by miners into the region known as La Pampa, there were between 1,000 to 1,500 farmers and forest concession holders. All were affiliated to the 30 organisations working in the Tambopata National Reserve Buffer Zone, from San Bernardo, at km 29 on the Interoceanic Highway, to Palmeras, in the area of the Inambari bridge.

What happened to them?

What happened to them? They were brutally invaded. And yet they resisted, they are still there, they have survived. We know who they are, we work with them on a day-to-day basis.

You mean they could be identified? They could help in the recovery of the zone?

It's not that they could help, they are helping. They are the best allies we have to recover the area. They are fully identified. We know who resisted at the cost of their assets, some even at the cost of their lives. We also know who allowed the invasion or did business with the illegal miners. As they say locally, we know who rolled over [paved the way, sold out] completely in collusion. They have to give back what no longer belongs to them. We want the users of these forests, who were denied their legitimate rights by illegal forces, to be able to recuperate what rightfully belongs to them.

Let's talk a little now about the recovery of La Pampa. Do you share the same optimism as the Ministry of the Environment?

This needs emphasising: the area that has been affected will need special treatment because people aren't going to be able to produce whatever they want there; the area is totally infected, polluted, and in these circumstances, the recovery will need to be a gradual one. It will involve rehabilitating all the basins, from the smallest to the largest. There will need to be a clean-up before any production can start. Firstly, we have to neutralise the pollution left by illegal mining in the wells and deserts; then, rebuild the basins and thirdly, and perhaps most importantly, reconstruct the profile of the affected land, which has been destroyed by enormous machinery, backhoe loaders, tractors, front loaders, etc. It will need to be repaired with the same machinery, not with shovels. In any case, these are long-term processes.

Could the La Pampa area recover like the meadows that have recovered in the Tambopata corridor where you have your Private Conservation Area? 
Yes, of course, if the animals come, as has been the case here. In La Pampa there used to be a number of wild animals. I clearly remember when there were jaguars all over the wetlands: if you crossed these forests you did so carefully. I would often have to stop in the middle of a stream, on a small bridge, for four, maybe five hours, waiting for the wild boar (peccary) surrounding us to leave. There was great biodiversity, nothing was lacking. The peasants miss those times, humble people miss this. They remember going to the stream and seeing crystal-clear water from which they would fish huge shad.

\section{Given what has happened, what is your current dream, Victor Zambrano?}

Before talking about my dreams, I would like to mention the people who have fought alongside their management committee for so many years. They are peasant farmers who feel that these forests are a part of their lives. It is not right for OSINFOR, the State body supervising forest resources, to punish them for not having been able to protect their forest concessions. It is obvious that a peasant, given the conditions they live in, may have no more than 15,000 or 20,000 soles in their pocket and it is unfair of the State to demand this of them. OSINFOR has not operated as it should in this region. We want the authorities in Lima to know this and to take necessary action.

\section{Your dream, Mr. Zambrano?}

I have always referred to the great love I have of these lands and the pride I feel in having been born here; I have always identified with my native brothers, particularly with my Ese Eja brothers, who have formed my reference point as far back as I can remember. Despite all that this land has suffered, the Tambopata National Reserve is still the protected natural area that attracts the greatest number of tourists in the whole of Madre de Dios. It will become an international attraction once again. The roads that have, up to now, been an open door to all kinds of illegalities, must bring us good people, people who value what we have so that we can begin to live off the forest, in harmony with nature, seeing all the creations that God gave us. We must rid ourselves of our bad image and focus on the fact that we are the biodiversity capital of Peru.

\section{Postscript}

MAAP (Monitoring of the Andean Amazon Project), an initiative implemented by a large Amazonian NGO that uses satellite technology to monitor deforestation in Peru, Colombia, Ecuador and Bolivia, offers us some important information: One. Over the last 17 years (2001-2017), 4.2 million hectares of Andean Amazonian forests have been lost. Peru has recorded the greatest annual loss, followed by Colom- 
bia and Ecuador. The vast majority of Amazonian deforestation (74\% on average) is taking place on a small scale ( 5 hectares), $24 \%$ on a medium scale (5-100 hectares), and only $2 \%$ on a large scale (>100 hectares). Two. Of this total, 50\% occurred in Peru (2.1 million), 41\% in Colombia (1.7 millions) and 9\% in Ecuador $(359,000)$. Three. Peru recorded the highest annual average deforestation between 2009 and 2016. The last four years have given the highest total annual deforestation in the country, with peaks in 2014 (177,566 hectares) and 2016 (164,662 hectares). According to new data from the Ministry of the Environment, there was a significant decline in 2017 (155,914 hectares); however, it still remains the fourth highest yearly total recorded. Four. The main causes of deforestation in Peru are related to agriculture (including oil palm, cocoa, and other small and large-scale crops), cattle rearing, gold mining, forest trails and highways. Agriculture and livestock rearing are the drivers of greatest threat to the whole Amazonian region. Five. 59 million metric tonnes of carbon have been lost in the Peruvian Amazon in the last five year (2013-17) due to the loss of forest cover. Six. In addition, protected natural areas and indigenous territories sequester 3.17 billion metric tonnes of carbon. Seven. Cocoa and papaya crops are emerging drivers in Madre de Dios while maize and rice are promoting deforestation around Iberia, in Madre de Dios. Eight. Illicit coca growing is causing deforestation in some areas of Peru and Colombia. For example, in the south of Peru, coca growing is causing deforestation around and inside the Bahuaja-Sonene National Park. Nine. The area most seriously affected by gold mining is Peru's southern Amazon where it is estimated that there has been historic deforestation of more than 95,700 hectares of forest (CINCIA 2018). Ten. Deforestation for mining has intensified over the last seven years (since 2010) with the areas most affected being La Pampa and Alto Malinowski, in Madre de Dios. There is another critical zone in the Amarakaeri Communal Reserve Buffer Zone, where deforestation due to mining can be found just one kilometre from the boundaries of this protected area. Further small gold mining areas are emerging in Peru's northern and central Amazon.

\section{BIBLIOGRAPHY}

CONTRERAS, Carlos. (1982). La ciudad del mercurio. Huancavelica 1570-1700. Instituto de Estudios Peruanos.

DIARIO EL COMERCIO. Madre de Dios: una economía relacionada con la actividad minera [REPORT], 11/04/2018 https://elcomercio.pe/peru/oro-brillo-selva-informe-noticia-510835

DÍAZ, Julio, Arana, Martín, Torres, Juan and Patrucco, Sandro. (2016). Historia ambiental del Perú. Siglos XVIII y XIX. Ministry of the Environment. 
DOUROJEANNI, Marc. (2009). Crónica forestal del Perú. UNALM - Editorial San Marcos. GRAY, Andrew. (2002). Los Arakmbut. Mitología, espiritualidad e historia, IWGIA.

FRONTERA PIRATA. https: / / medium.com/ frontera-pirata

HUERTAS Castillo, Beatriz and García Altamirano, Alfredo, (2003). editors. Los pueblos indígenas de Madre de Dios. Historia, etnografía y coyuntura. IWGIA.

MARKHAM, Clements. (2001). Cuzco and Lima. Ediciones COPÉ-Markham College.

MOORE, Thomas. (2003). La etnografía tradicional arakmbut y la minería aurífera. In: Los pueblos indígenas de Madre de Dios. Historia, etnografía y coyuntura. IWGIA.

REAÑO, Guillermo. (2018). Vida plena y rescate cultural en la Reserva Comunal Amarakaeri, territorio ancestral del pueblo Harakbut, At https: / / porlatierra.org/ casos / 166

SOCIEDAD PERUANA DE DERECHO AMBIENTAL. (2015). Las rutas del oro ilegal. Estudio de caso en cinco países amazónicos.

SUEYO Irangua, Antonio y Sueyo Yumbuto, Manuel. (2018). Soy Sontone. Memorias de una vida en aislamiento. IEP - Ministry of Culture. 


\title{
THE TERRITORIAL CORRIDOR OF THE PANO, ARAWAK AND OTHER PEOPLES: GUARANTEEING THE INTEGRITY OF INDIGENOUS PEOPLES IN ISOLATION AND INITIAL CONTACT ${ }^{1}$
}

\author{
Beatriz Huertas Castillo
}

\section{Introduction}

The vast Amazon forest, stretching more than 2,800 km along the border between Peru and Brazil and forming an arc that extends from the mouth of the Yavarí River in the north as far south as the town of Iñapari on the Acre River, is an area of particular sociocultural and environmental importance. This crossborder region is home to a large number of different indigenous peoples, including some living in isolation and initial contact, whose territories are located contiguously across large forested areas. These indigenous territories are also home to the sources of rivers of particular significance to the Amazon Basin and its forests; the lands are characterised by their high biodiversity, where the States have established protected natural areas.

One of the great blocks of indigenous territories existing in the area is known as the "Territorial Corridor of the Pano, Arawak and Other Peoples" ("Territorial Corridor"), inhabited by peoples living in isolation and initial contact, largely Arawak- and Pano-speaking and who, around their borders, share territories with different indigenous peoples organised into native communities and settlements. We therefore understand "territorial corridor" to mean a geographic space made up of indigenous territories located continuously and interrelated among themselves.

Virtually $60 \%$ of the area of this Territorial Corridor is made up of areas officially recognised and established for indigenous peoples: indigenous/territorial reserves, titled native communities (Peru) and official indigenous lands (Brazil). The remainder mostly comprises protected natural areas, conservation concessions and

1. This article was written, on the basis of a 2015 study conducted by the author, to justify the existence of the Territorial Corridor of the Pano, Arawak and Other Peoples. This was at the request of the platform of organisations for the protection of peoples in isolation and initial contact. This coordinating body comprises the following indigenous organisations: the Interethnic Association for the Development of the Peruvian Forest, (Aidesep), the Regional Organisation of Indigenous Peoples of the East (ORPIO), the Regional Organisation of Indigenous Peoples / Aidesep-Ucayali, (ORAU), the Native Federation of the Madre de Dios River and its Tributaries (Fenamad), the Regional Coordinating Body of Indigenous Peoples / Aidesep-Atalaya (CORPIAA), and the Machiguenga Council of the Urubamba River (Comaru). The study was supported by Rainforest Foundation Norway. 
Permanent Forest Production Forests. Dozens of forestry concessions have been granted within the latter, most of them inactive but which have become highly deforested due to road and highway construction, as well as due to forest extraction itself. In the last 15 years (2004-2019), the construction of international highways such as the Southern Interoceanic Highway has placed increased pressure on indigenous forests and territories in the Corridor, adding to the socioenvironmental impacts caused by the heavy promotion of new local-level roads on all sides. ${ }^{2}$

This article analyses the advancement of deforestation towards the Territorial Corridor caused by forest highway and road construction, as well as the threat this represents for the indigenous peoples living there and their territories. It further makes the case for the protection of the Territorial Corridor, an initiative that is being promoted by indigenous organisations and their civil society allies in order to halt the deforestation, guarantee the integrity of the peoples in isolation and initial contact, improve territorial governance within the indigenous communities and to protect the forests and river headwaters.

\section{Indigenous peoples}

The Territorial Corridor of the Pano, Arawak and Other Peoples, located in the crossborder area between the regions of Ucayali, Madre de Dios and Cusco in Peru, and Acre State in Brazil, is inhabited by many different indigenous peoples living both in isolation and initial contact and organised into native communities and settlements.

Most of the peoples living in isolation (meaning those who have rejected direct and sustained interaction with the surrounding population) are members of the Pano and Arawak linguistic families. Pano-speaking peoples are related ethnolinguistically to the wider Yaminahua group and are known as Chitonahua, Mastanahua or Curanjeño by neighbouring groups. The Arawak-speaking peoples in isolation are known as Mashco Piro and Matsiguenka (Nanti from the Manu, Paquiría and Cashiriari river basins). There are also other groups of unknown ethnicity and who are known by the rivers or areas they live in: "isolated peoples of the upper Sepahua- Purús", "isolated peoples of the Riozinho", "isolated peoples of the Jordão" or "isolated peoples of Acre".

The peoples classified as "in initial contact", meaning those who have re-established interactions with their surrounding environment under conditions that make them immunologically vulnerable are: the Nahua, the so-called "People of Xinane", as well as members of the Chitonahua, Mastanahua and Matsiguenka

2. This article uses concepts of pressure and threat as developed by RAISG (2019). As such, pressures are actions of human origin that endanger the integrity of ecosystems and the collective rights of inhabitants. Threats are planned future initiatives that may become pressures once implemented. See: https://www.amazoniasocioambiental.org/es/publicacion/presiones-y-amenazas-sobre-las-areas-protegidas-y-los-territorios-indigenas-de-la-amazonia-2 / 
peoples. Some Amanuaca families from the upper Yurúa also maintain sporadic relations with their relatives settled along the Inuya River, a tributary of the Urubamba.

Parts of the Territorial Corridor have been declared territorial/indigenous reserves, a status established in Peruvian legislation for peoples in isolation and initial contact. These are the Murunahua, Mashco Piro (Ucayali), Madre de Dios (Madre de Dios) and Kugapakori Nahua Nanti and Other Peoples (Ucayali and Cusco) reserves. For its part, Brazilian legislation has established the status of "Indigenous Land" for the territories of indigenous peoples. There are 11 of these in the Territorial Corridor, mostly inhabited by both settlements and peoples in isolation.

In fact, around the edges of the Territorial Corridor, on both sides of the border and sharing land with peoples in isolation, live some 20 communities and settlements made up of members of another 11 indigenous peoples, with an approximate population of 7,500 individuals. These are the Uni Kuin or Cashinahua, Yaminahua, Sharanahua, Amahuaca, Mastanahua and Shipibo (of the Pano linguistic family), Matsiguenka, Ashéninka, Asháninka and Yine (Arawak), Wachipaeri (Harakbut) and Madijá (Arawa).

This high concentration of indigenous peoples, both in isolation and initial contact, as well as organised into communities and settlements, with territories that adjoin and form a vast and continuous block, has led the indigenous organisations affiliated to Aidesep to call the area the "Territorial Corridor of the Pano, Arawak and Other Peoples". The Territorial Corridor extends over an area of 8,890,000 hectares and is socioculturally highly sensitive due to the territorial and immunological vulnerability of the peoples living there in isolation and initial contact.

\section{Forests, rivers and protected areas}

The Territorial Corridor is also home to the sources of rivers of great significance to the Amazon Basin, such as the Acre, a tri-national sub-basin that courses through Peru, Brazil and Bolivia; and bi-national sub-basins such as the Yurúa, Breu, Purús, Chandless, Yaco, Envira (Peru-Brazil) and Tahuamanu (Peru-Bolivia). Together with the forests, the headwaters of hydrographic basins and sub-basins play an important part in regulating the water cycle which, in the case of the Territorial Corridor, affects the whole (Amazon) region. This means that it helps to maintain the quality and quantity of the water, the dry-season levels and soil protection in terms of infiltration and water quality, etc. ${ }^{3}$ In terms of environmental services, the Territorial Corridor's extensive water system thus provides a source of clean water to both the peoples living within it and the surrounding population. ${ }^{4}$

The existence of important protected natural areas within the Territorial Corridor is an indicator of the area's environmental value. It comprises the Manu and Alto

3. ftp: / /ftp.fao.org/tc/tca/WEB/FTP/TC/TCA/ESP/pdf/urquijo/Bloquell.8.pdf 4. Law 30640 of 2017 indicates that the State recognises the sources of a hydrographic basin's rivers as environmentally vulnerable zones. 
Purús national parks, the Megantoni National Sanctuary and the Purús Communal Reserve. The proximity of these areas to each other has also led environmental organisations to identify biological, ecological or conservation corridors. The Purús-Manu Corridor, for example, promoted within the context of the Initiative for the Conservation of the Andean Amazon (ICAA), is one of the main conservation corridors of the Peruvian Amazon and home to the greatest diversity of life on earth (Huertas, 2015:41). The Kugapakori Nahua Nanti Territorial Reserve and the Manu National Park, situated to the south of the Territorial Corridor, are also home to the Vilcabamba Amboró Corridor, one of 25 global protection zones located in the tropical Andes, and considered one of the most diverse regions in the world due to its high endemism.

\section{Map $\mathrm{N}^{\mathrm{o}}$ 1. Territorial Corridor of the Pano, Arawak and Other Peoples}
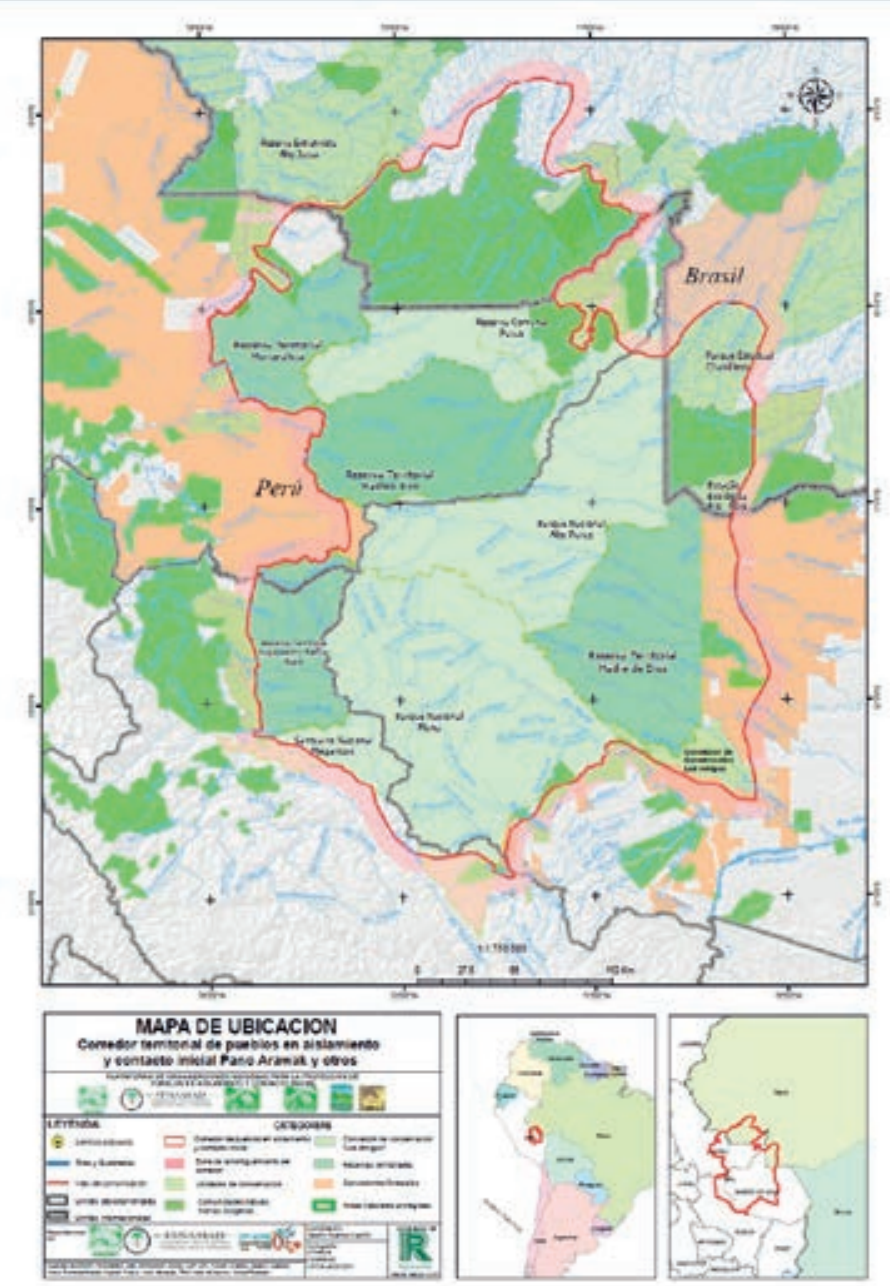

Source: Aidesep - Pro Indio Acre Commission, 2015 
On the Brazilian side, in Acre State, the indigenous lands and conservation units that form part of the Territorial Corridor include the State System of Protected Natural Areas (SEANP). This system, covered by State Law No. 1,426 (2001), is an ecological corridor "that acts as a natural protection system for the existing diversity of animals and plants, with a continuous area of forest along the whole international border between Peru and Bolivia. It prioritises not only the flora and fauna but also the communities living in these areas." (SEMA et al, 2010:60).

\section{Deforestation in the Territorial Corridor and surrounding areas}

According to the National Forestry and Wildlife Service (SERFOR, 2018), by 2017 Peru had lost a total of 7.7 million hectares of natural forest. The Ministry of the Environment's Programme of National Forest Conservation for Climate Change Mitigation (2018) indicates that 155,914 hectares were deforested in 2017 alone, with the greatest loss of trees occurring in the Ucayali and Madre de Dios regions (29,905 and 23,669 hectares respectively). The area deforested that year in Madre de Dios was the most extensive since 2001, when the Programme's monitoring began (Peruvian Environmental Law Society - SPDA, 2018). This region has therefore suffered one of the highest densities of forest loss or deforestation in the Peruvian Amazon and presents virtually all the drivers of a loss of forest cover: agriculture, mining, highways and forestry roads. While it is clear that the most critical areas of forest loss in Madre de Dios are around the gold mining area, and along the South Interoceanic Highway, growing deforestation has been identified as a result of road construction associated with forestry concessions in Tahuamanu province, affecting areas of the Territorial Corridor (See: "Critical points or hotspots for deforestation in Madre de Dios in 2017" in map included in page 218).

\section{Forestry roads}

One of the main reasons behind this notable increase in deforestation in the country is the construction of a network of secondary roads that link to the main highways, many of them forestry roads. Villa and Finer (2019) estimated that 3,300 km of forestry roads were constructed in the Peruvian Amazon between 2015 and 2018, mostly in the north-east of Madre de Dios and Ucayali. In 2017, based on a Deforestation Early Warning (ATD) analysis, the Ministry of the Environment (2018) identified 1,416 km of newly-cleared forestry roads, $41 \%(591 \mathrm{~km})$ of which were in Madre de Dios, 36.8\% (521 km) in Ucayali and 11.9\% (167.9 km) in Loreto. More than half $(51.7 \%)$ of these roads were located within areas of forestry concessions, with Iñapari district (Tahuamanu province, Madre de Dios) having the greatest length of such roads opened $(266.7 \mathrm{~km})$, more than all those opened throughout Ucayali that same year put together (SPDA, 2018). The roads in this district are 
largely branches of the Catahua forestry concession-Iñapari forestry road (140 km long) which joins the South Interoceanic Highway.

As José Capella, from the Peruvian Society for Environmental Law indicates:

"A warning was issued several years ago that the construction and improvement of secondary roads joining the South Interoceanic Highway was a factor of increased deforestation in Madre de Dios. These new roads were being opened and forestry roads improved without environmental certification and without the authorisations required by current regulations. Moreover, they connect areas of virgin forest (given their level of conservation) to activities that are the drivers of deforestation, from subsistence agriculture through to criminal activities such as illegal mining, land grabbing and trafficking, as well as unlawful felling" (Ibid).

A significant proportion of the forestry roads built in the Iñapari district in the last four years (2015-2018) have cut through an area inhabited by indigenous peoples living in isolation that lies adjacent to the Madre de Dios Indigenous Reserve (created for indigenous peoples in isolation). The presence of these roads creates an environment of extreme social vulnerability given that the logging company staff could pass on diseases to these peoples, quite possibly triggering their mass destruction. There is also a risk that conflict will arise over the invasion of their territory. In 2016, the Multisectoral Commission that was established to oversee Law 28736 (Law for the Protection of Peoples Living in Isolation and Initial Contact) approved an extension of the Indigenous Reserve to the east to include territories inhabited by these people but lying outside the reserve. This decision, however, has not yet been implemented. This concentration of forestry roads is extremely dangerous for the integrity of the people living in isolation in this area, which corresponds to the eastern part of the Territorial Corridor.

There are also forestry roads connecting the South Interoceanic Highway to forestry concessions located on the Madre de Dios River, such as "Wood Tropical Forest", and others in Ucayali, the opening of which is advancing dangerously close to the Territorial Corridor. 
Map $\mathrm{N}^{\circ}$ 2. Forestry roads opened in the Iñapari district, Madre de Dios, between 2015 and 2018, close to the Territorial Corridor of the Pano, Arawak and Other Peoples

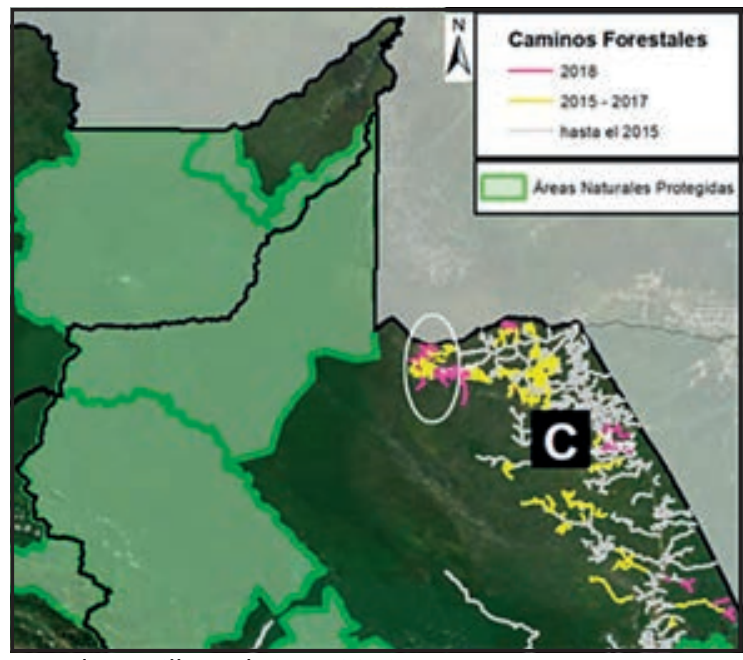

Based on: Villa and Finer, 2019

Map $N^{o}$ 3. Area approved as an extension of the Madre de Dios Indigenous Reserve

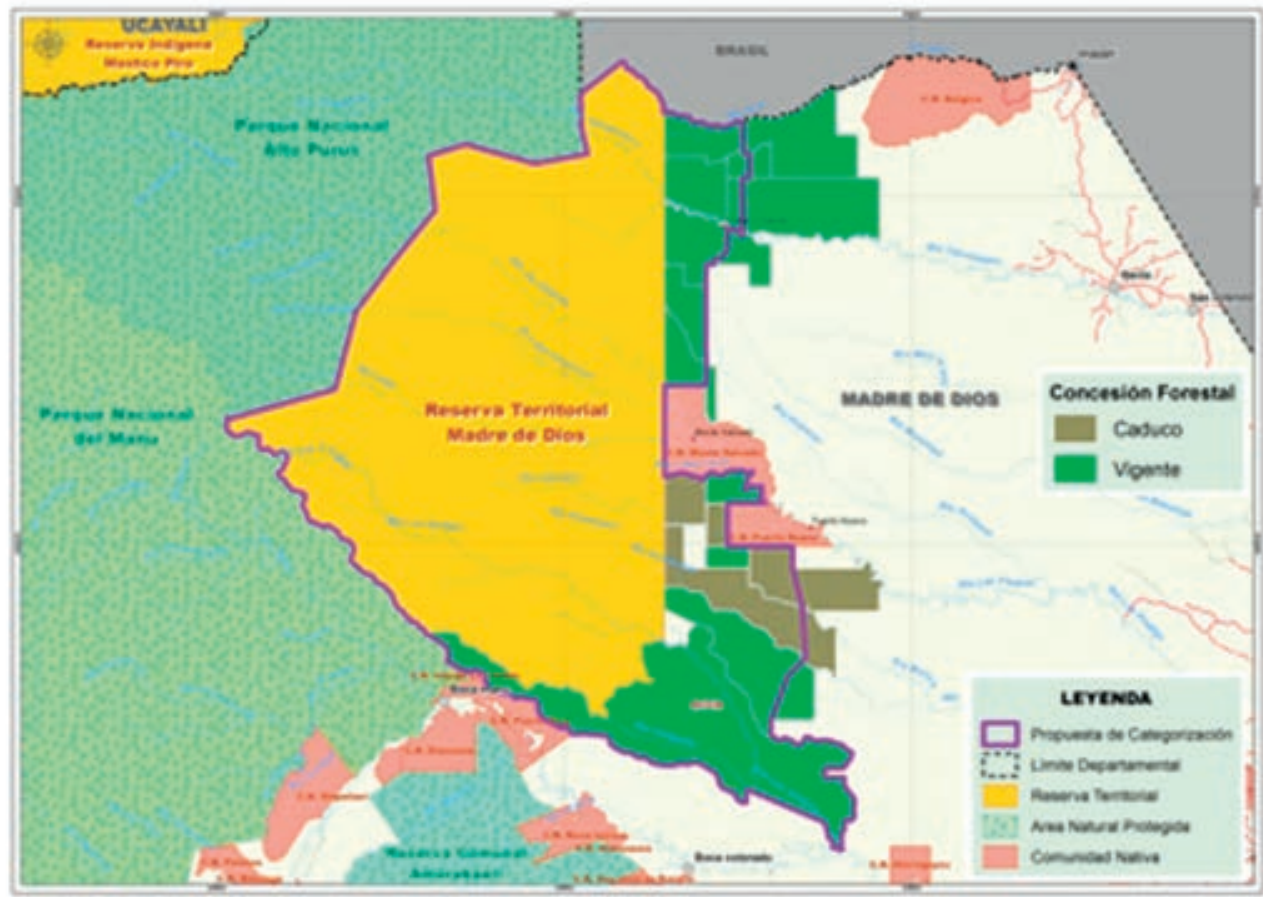

Source: Ministry of Culture, 2017 


\section{Highways}

The South Interoceanic Highway is the largest and most significant highway in the area of the Territorial Corridor and, indeed, in the whole of Peru's southern Amazon.

\section{South Interoceanic Highway}

Its construction was proposed within the context of the Initiative for the Integration of South American Regional Infrastructure (IIRSA), an institutional mechanism for coordinating the intergovernmental actions of 12 South American countries with the aim of establishing a common agenda to integrate transport infrastructure, energy and communications projects. ${ }^{5}$ At 2,592.46 km long (CAF, 2013), it was one of the largest transport infrastructure projects to be undertaken in Peru over the 2005-2010 period. The Brazilian government played a very important role in its development due to its interest in gaining a route to the Pacific Ocean and thereby accessing Asian markets for the exportation of its products. The road goes through the Madre de Dios region, starting at the town of Iñapari. On reaching Cusco, it joins the Southern Pan-American Highway, heading towards the ports on the Peruvian Coast. It is divided into five sections: 1 . San Juan de Marcona - Urcos; 2. Urcos - Inambari; 3. Inambari - Iñapari; 4. Inambari - Azángaro; 5. Matarani - Azángaro, Ilo - Juliaca (CAF, 2013). This route covers eight departments: Madre de Dios, Cusco, Puno, Arequipa, Ica, Apurímac, Ayacucho and Moquegua.

In 2004, Law 28214 declared the highway's construction to be in the national interest: a public necessity that should be implemented as a priority. One year later, by means of Supreme Decree No. 022-2005-EF, the regulations governing the National Public Investment System (SNIP) were waived for those sections under concession despite being at the important pre-investment stage. In addition, the project was approved, initiated and financed without any environmental impact study. This also resulted in a failure to comply with the guidelines and procedures of the Andean Development Corporation itself, which was partially promoting and financing it. There was, furthermore, a lack of public mechanisms in place to ensure that the worst socioenvironmental impacts could be avoided. The highway's construction was plagued with irregularities and a lack of planning, and this was also reflected in the cost of the work: initially estimated at USD 940 million, changes during its implementation saw the cost rise to USD 2 billion (Alberti and Pereyra, 2018:26).

By 2019, a decade after its completion, the highway's failure to positively affect the dynamics of the local economy stands in contrast to its socioenvironmental impacts, in particular the growing deforestation aimed at establishing mono-

5. http: / / www.iirsa.org/Page/ Detail?menuItemId=28 
cropping and the opening of multiple forestry roads, including some running close to or even as far as the Territorial Corridor. This is in addition to the greater pressure being placed on natural resources through felling and mining, a proliferation of illicit activities, land trafficking and widespread crime. As Alberti and Pereyra indicate (op. cit: 31), it is reasonable to assume that the way in which the South Interoceanic Highway (IIRSA) was implemented, with accelerated pre-investment that made it feasible only from a political point of view, has had an impact on its economic viability and socioenvironmental sustainability. ${ }^{6}$

\section{Map $\mathrm{N}^{\mathrm{o}}$ 4. South Interoceanic Highway, roads and secondary forestry roads close to the Territorial Corridor}

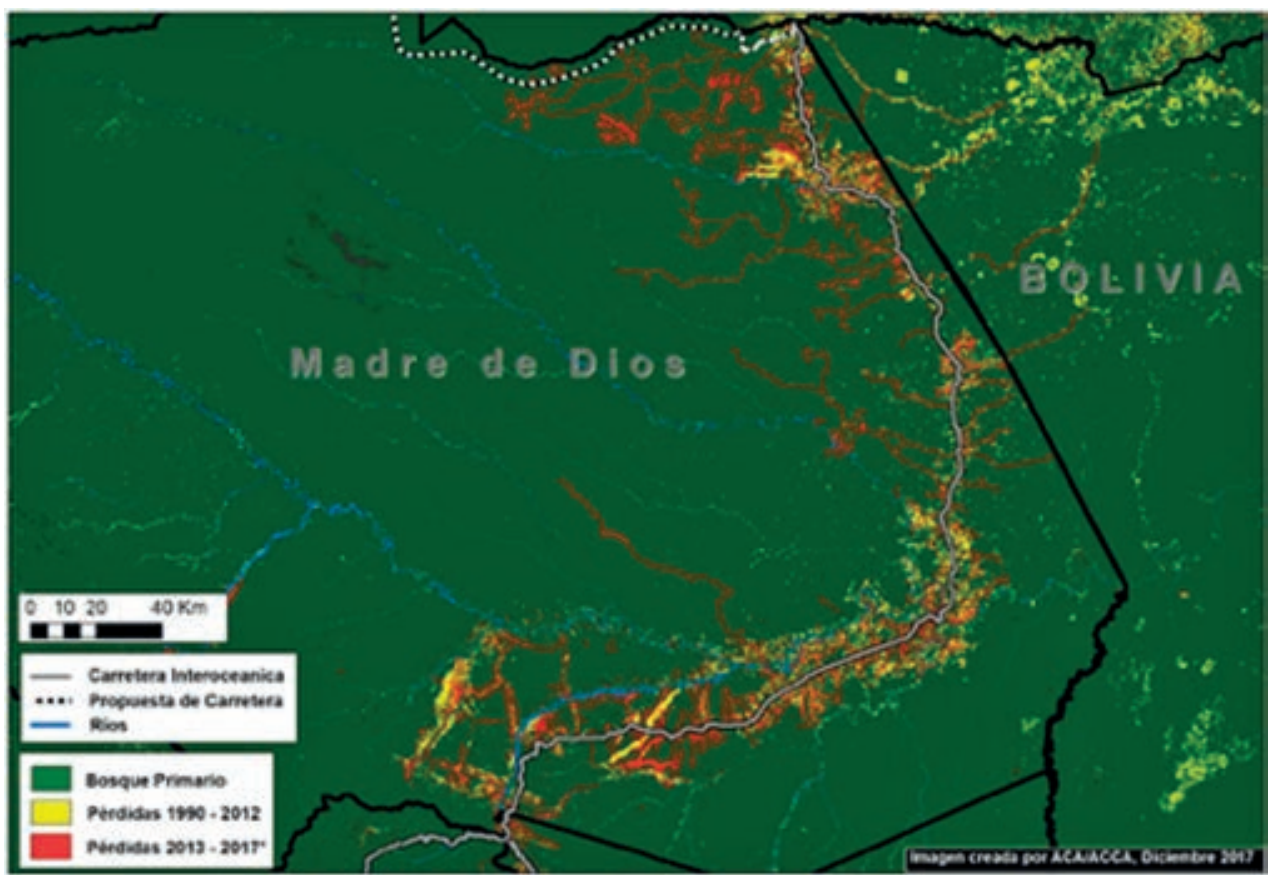

Source: ACCA, 2018a

6. According to Peru's Attorney-General's Office, investigations into cases of corruption involving the Brazilian company, Odebrecht, during the bidding process initiated in 2005 for the construction of sections 2 and 3 of the highway brought to light the payment of bribes to former President Alejandro Toledo, to the sum of USD 20 million, in favour of the consortium comprising Norberto Odebrecht SA, Graña y Montero SA, JJ Camet Contratistas Generales SA and Ingenieros Civiles Asociados de CV. See: https://www.mpfn.gob.pe/ equipo_especial/caso_interoceanica_tramos2y3/ 


\section{Road projects}

Madre de Dios Regional Integration Highway, Nuevo Edén-Boca Manu-Boca Colorado section

This is a regional road project in Madre de Dios that cuts across the buffer zones of the Amarakaeri Communal Reserve and the Manu National Park, on the upper Madre de Dios River. The area lies along the southern edge of the Territorial Corridor of the Pano, Arawak and Other Peoples, and is inhabited by the Mashco Piro (of the Manu) people living in isolation, the Matsiguenka in isolation, and initial contact and native communities including members of the Yine, Matsiguenka and Harakbut peoples.

During 2015, without any technical opinion from SERNANP, and with no environmental impact study having been conducted, the Madre de Dios Regional Government built an $11.6 \mathrm{~km}$-long section of road between Nuevo Edén and the Shipetiari native community. In 2016, it moved onto a second section $21.8 \mathrm{~km}$ long. In all, $33.4 \mathrm{~km}$ have been laid within the buffer zone of the Amarakaeri Communal Reserve (Association for the Conservation of the Amazon Basin, 2016). By midMarch 2016, this had resulted in the almost immediate deforestation of 32 hectares of forest (op. cit). In addition, it encouraged activities that were prohibited, such as the transportation of fuel for illegal mining, timber extraction from the buffer zones and the invasion of indigenous territories (Ministry for the Environment, 2016). As noted in the audit report produced by the Comptroller-General of the Republic, which evaluated the Madre de Dios Regional Government's management between January 2013 and December 2014 (2016): ${ }^{7}$

“...construction of the highway was undertaken by the Madre de Dios Regional Government without any environmental certification being issued by the Ministry of Transport and Communications [...] and without the prior favourable technical opinion of SERNANP [...]. The stated actions have resulted in highly significant environmental impacts, including: a loss of soil fertility, compaction of the soil, effects on the water cycle and sedimentation, loss of plant cover, loss of carbon capture capacity and loss of habitat, affecting the migration routes of species, and reducing the food supply available to them".

In November 2015, the Congress of the Republic approved Draft Bill of Law No. 2330-2012 / CR at its first reading, "declaring the construction of the Madre de Dios Regional Integration Highway: Nuevo Edén - Boca Manu - Boca Colorado section to be of public necessity and in the national interest". Its danger to indi-

7. Audit Report $\mathrm{N}^{\circ}$ 060-2016-CG/MA-AC. See: https://www.actualidadambiental. $\mathrm{pe} / \mathrm{p}=3740$ 
genous peoples and to protected natural areas led to its rejection by civil society organisations and even the national government itself, which observed that the proposal was unconstitutional for the following reasons: 1. It affects the fundamental right of all people to a balanced and appropriate environment in which to live, as stated in Article 2.22 of the Political Constitution of the State. 2. It fails to meet the primary constitutional obligation to promote the conservation of biological diversity and the protected natural areas, based on the provisions of Article 68 of the Constitution. 3. It flouts the provisions of Article 79 of the Constitution given that it is not the Congress of the Republic's position to prioritise an investment project through the passing of a law (Ministry of the Environment, 2016).

\section{Map $N^{\circ} 5$. Planned highway route from Nuevo Edén-Boca Colorado}
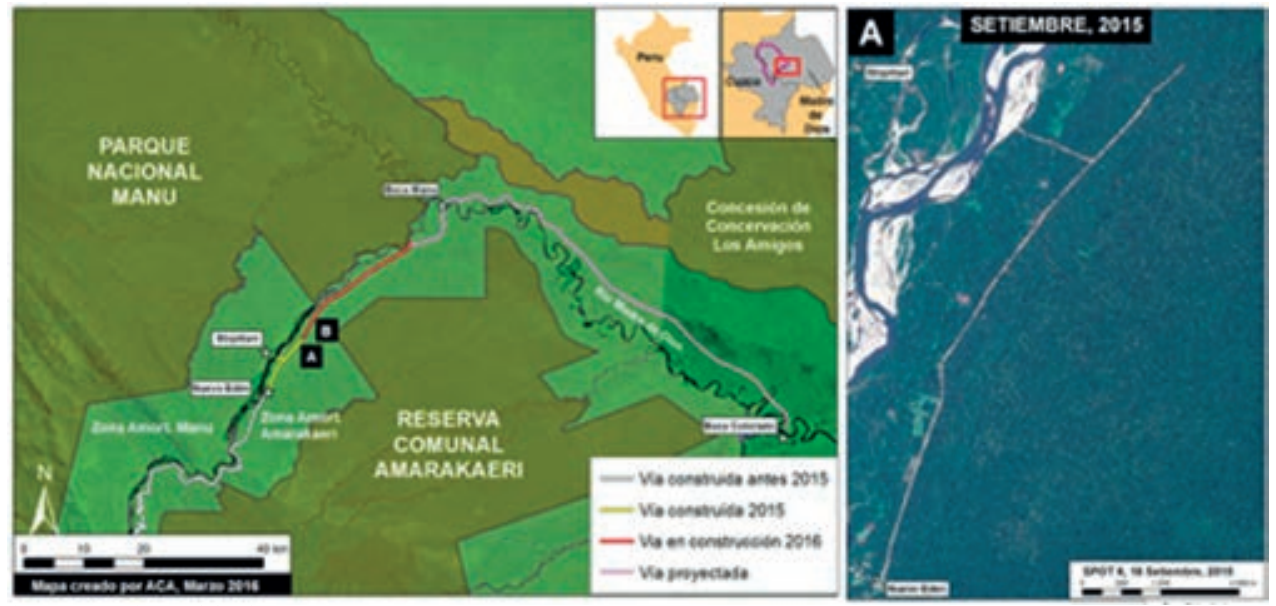

Source: ACCA, 2016

\section{Puerto Esperanza - Iñapari Road}

The politico-religious authorities of Puerto Esperanza, capital of the province of Purús (Ucayali region), have been proposing the construction of a highway to Madre de Dios since the early 2000s. Its route would be an extension of $277 \mathrm{~km}$, with $22 \mathrm{~km}$ from Puerto Esperanza already built, and $140 \mathrm{~km}$ comprising the Iñapari-Catahua concession forestry road, which connects to the South Interoceanic Highway. This planned route directly crosses the headwaters of the Chandless, Yaco, Acre and Tahuamanu rivers, which rise in Peru and flow towards Brazil. They form part of the Territorial Corridor. The area of direct impact will encompass the Purús Communal Reserve, the Alto Purús National Park and the Madre de Dios Territorial Reserve for indigenous peoples living in isolation, located in the central part of the Territorial Corridor and inhabited by Pano and Mashco Piro peoples living in isolation. According to ACCA (2018), 275,000 hectares of primary forest will be in danger if this highway is built. 
In 2006, members of the Congress of the Republic submitted Draft Bill of Law No. 1295/2006-R to the Transport and Communications Committee of Congress for review. This proposed linking the Puerto Esperanza-Iñapari road to the South Interoceanic Highway (IIRSA). It was hoped that this road would overcome a number of problems: the poor urban infrastructure around Purús, the lack of interconnectivity with the region, the lack of infrastructure to support production activities, the lack of private investment standards and the lack of diverse services which limit the development possibilities for the inhabitants of Purús. ${ }^{8}$

Having analysed the draft bill, the Committee concluded that: 1 . The Iñapari - Purús link road does not form one of the sections included in the Peru-Brazil IIRSA Interoceanic Highway project and nor has any study been conducted for the implementation of this link road; 2. Access to Purús, given its geographical location, is difficult and costly, and so possible implementation of the project described in the draft bill may well require more than USD 300 million. Given its length, it would be similar to the section that links Inambari and Iñapari, which has a referencial investment of more than USD 332 million; 3. The approval of the draft bill would be in contradiction to Article 76(2)i of the Regulations of the Congress of the Republic, which notes that draft bills presented by Congressional members may not contain proposals that either create or increase public expenditure; 4 . The power to decide on highway construction lies with the national government, in coordination with regional governments, and in accordance with the regulations applicable to public investment projects. ${ }^{9}$

On 19 April 2012, six years later, a similar proposal was presented once again, this time proposing the possibility of building either a road or a rail link. This was Draft Law No. 1035-2011/CR, a "Law declaring the public necessity and priority in the national interest of an overland connection between Puerto Esperanza, in the border province of Purús, Ucayali region, and Iñapari, in the border province of Tahuamanu, Madre de Dios region, by means of a road or rail link between Puerto Esperanza, capital of Purús, and Iñapari, capital of Tahuamanu"10. On 1 June of the same year, the Transport and Communications Committee of Congress issued a favourable opinion, without taking into consideration the observations made years previously.

A few days later, the Vice-Ministry of Interculturality sent the Transport and Communications Committee an official letter in which it stated that it did not approve the decision due to the lack of technical viability studies and cost/benefit analyses, and

8. Draft Bill of Law No. 1295/2006-CR.

9. Opinion on Draft Bill of Law No. 1295/2006-CR, which proposed incorporating the Puerto Esperanza-Iñapari Highway Link into the "South Interoceanic Highway (IIRSA)". Congress of the Republic, 13 November 2007.

10. Opinion on Draft Bill of Law 1035/2011-CR, issued by the Transport and Communications Committee of Congress. 
the risks to the life and health of the peoples living in isolation in Madre de Dios as well as the impacts on the rights of the native communities of the area. SERNANP also issued an opinion against approving this project due to the effect it would have on the protected areas of the Purús Communal Reserve and the Alto Purús National Park.

The indigenous peoples also rejected the draft bill of law, through their organisations Feconapu, Fenamad, ORAU and Aidesep, referring to the impact it would have on the people living in isolation, while environmental organisations emphasised the unconstitutional nature of building a road or rail link through a protected natural area of indirect use, in violation of Article 69 of the Political Constitution which enshrines the State's duty to conserve protected natural areas. In addition, it was noted that it was in violation of the rights of indigenous peoples, forestry concession holders and a forest management association. ${ }^{11}$

As a remedy for Purús' lack of connectivity with the rest of the country, civil society organisations suggested an airstrip, which would require less disruption to the ecosystem and would benefit the area's indigenous and settler population, as well as the indigenous peoples living in isolation in the territorial reserves and protected natural areas: "An airstrip could help border integration by improving the provision of health services, sanitation, energy, education and public safety, bringing the State to the rural environment and drawing on the support of SERNANP and its staff already present in the area" (WWF et al 2012).

In response to observations from civil society organisations and government institutions, Law 30574 was enacted in July 2018 declaring the sustainable development of Purús province to be of public necessity and in the national interest, prioritising multimodal connectivity that would ensure unconditional respect for protected areas and the indigenous peoples living therein. Just months later, however, the Congress of the Republic approved Draft Bill of Law No. 11223 declaring the construction of highways in the border areas of the Ucayali region to be in the national interest.

11. WWF et al, 2012. "Opinion on Draft Bill of Law 1035/2011-CR, aimed at declaring the public necessity and priority in the national interest of providing an overland connection between the town of Puerto Esperanza in the border province of Purús, Ucayali region, and the town of Iñapari in the border province of Tahuamanu, Madre de Dios region, by means of a rail or road link between Puerto Esperanza, capital of Purús, and Iñapari, capital of Tahuamanu, Lima". 
Map $N^{o}$ 6. Route of the planned Puerto Esperanza-Iñapari highway

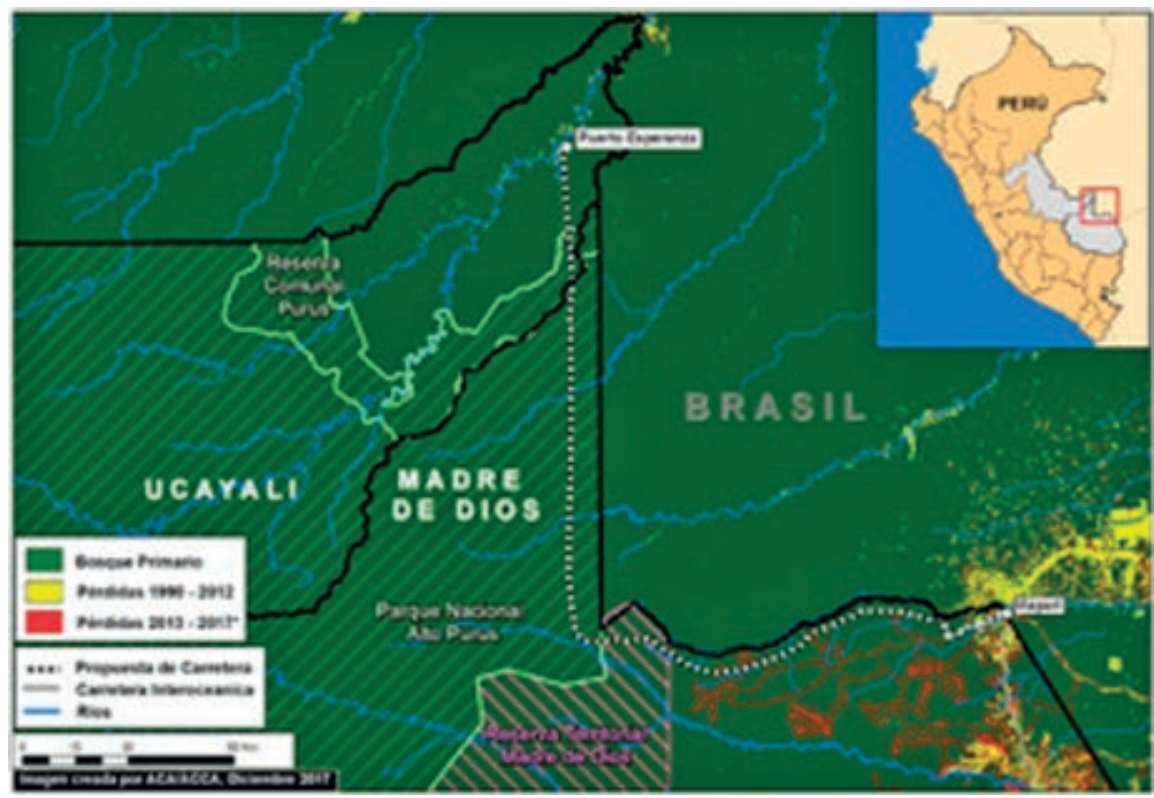

Source: ACCA, 2018b

\section{Breu - Nueva Italia Highway, Ucayali}

In the 2000s, the Forestal Venao SRL company began to use the route of a forestry road which, years previously, had been laid by oil companies to link Yurúa district with the settlement of Nueva Italia, in Tahuanía district, on the banks of the Ucayali River. The company was using it to transport timber extracted from its concession and from the native communities of the area. ${ }^{12}$ The stretch covered approximately $92 \mathrm{~km}$ and could only be used in the summer, when it was dry, because it became impassable in the rainy season. The municipalities of Atalaya and Yurúa are now urging its completion under a vision of "strengthening the Sawawo native community (Milestone 40) as a border development hub of high indigenous influence, consolidating the sustainable management of the Murunahua - Tamaya Regional Conservation Area and linking the province of Atalaya with Brazil, encouraging the province's development" (Ministry of Energy and Mines, MINEM - Provincial Government of Atalaya, 2007:97). In 2007, spontaneous settlements of casual farmers sprang up the whole length of the highway.

In addition to this road, the Atalaya Province Land Management Plan (MINEM-Provincial Government of Atalaya, 2007:138) proposed a series of road projects including: the Atalaya - Inmaculada (Inuya River) dirt road, given that

12. There are complaints of illegal timber extraction by this company in Yurúa district. 
this is the second largest agricultural and livestock farming area in the province; the Sepahua - Poyeni - Puerto Ocopa dirt road, as a crosscutting link road; and the crosscutting rail link project between Atalaya - Sepahua - Purús. All of these routes run along the western border of the Territorial Corridor.

\section{The socioenvironmental impacts of road construction}

According to the Ministry of the Environment (2016), in addition to deforestation, road infrastructure works result in a series of negative environmental impacts on the physical and biological environment, as well as on the well-being of the population who depend on these resources. Based on experience of work in protected natural areas, the following negative environmental impacts have been identified:

Effects on the physical environment: soil and water

1. Reduction in soil fertility. Deforestation means that the area ceases to contribute any organic matter to the soil. A process of erosion commences along with the loss of its natural production capacity.

2. Soil compaction. This results in a loss of capacity to retain water and a lack of aeration, reducing its capacity to receivenutrients. The grow th of new plant cover is thereforeimpeded and the soil cannotbeused for any otheractivity.

3. Effects on the water cycle and sedimentation. Deforestation reduces the forest's capacity for water retention and for regulating evapotranspiration (loss of water that affects the ecosystem's microclimate). Changes in the patterns of water availability alter the composition and quality of plant communities.

Effects on the biological environment: flora and fauna

1. Loss of plant cover. Deforestation cuts the area's ecosystem in two and prevents biological connectivity and normal natural development.

2. Loss of carbon capture capacity. The forests influence the carbon balance in the atmosphere because they rapidly store large amounts of carbon. In contrast, deforestation reduces carbon storage and increases the quantity of $\mathrm{CO}_{2}$ being emitted into the atmosphere, exacerbating the climate change crisis.

3. Loss of habitat for wildlife species. The main effect on wildlife occurs due to the degradation of the forest's value as a refuge and provider of food and adequate conditions for species' reproduction.

4. The density of highways is closely related to the intensity of deforestation, above all in areas of weak governance and where there are incomplete processes for forest land planning and for granting rights over 
lands and forests. The prospect of large roadworks in the Amazon in the near future consequently demands that attention be given to this issue. Although roads are necessary for integration and connectivity, they can result in both direct and indirect deforestation.

5. Direct impacts occur along the whole length of the road and in the surrounding areas, extending to at least one kilometre either side. These impacts are due to the movements of earth and the use of riverbeds as quarries. Indirect impacts - the most significant and lasting - are felt in terms of ecological, social and economic processes, not only due to greater access and cheaper transport but also due to the expectations that are raised. In practice, the indirect impacts tend to cover an area of up to $50 \mathrm{~km}$ either side of the route.

Social impacts

In 2006, Marc Dourojeanni forecasted the social impacts that the South Interoceanic Highway would have. Among the most significant he highlighted the following:

- Increased migration from the Andes to the Amazon region

- Invasions of indigenous land generally

- Conflicts over lands and their regularisation

- Migration to the cities and increased urban poverty, plus a lack of public services in disadvantaged neighbourhoods

- An increase in illegal activities, a decline in public safety and a dilution or loss of traditional cultural values.

As anticipated, the paving of the South Interoceanic Highway unleashed the arrival of large numbers of immigrants into Madre de Dios, coming from the southern highlands of Peru. According to the 2007 Population Census (National Institute for Statistics, 2008), population growth in Madre de Dios hit 63.5\%, making it the fastest growing region in the country. Pressure on land and natural resources brought with it land trafficking, invasions and clashes, as well as a notable increase in public insecurity. One of the areas most affected was Tahuamanu province, which borders the Madre de Dios Territorial Reserve for indigenous peoples living in isolation and provides access to the Territorial Corridor for the Pano, Arawak and Other Peoples.

Dammert (2018: 17) noted that, in addition to the deforestation caused by the actual construction of the roads themselves through tropical zones, economic and social dynamics are also generated that result in a further loss of forested areas. These dynamics are a consequence of easier access to markets and basic services, which encourage an intensified use of the land and, consequently, a considerable increase in land prices in areas close to the road, hence the historic relationship 
between road construction and deforestation processes in the Amazon. Citing the National Forests and Climate Change Strategy (ENBCC), the same researcher indicates that, over the 2001 - 2014 period, the Madre de Dios region suffered the fifth highest level of deforestation in the country. Following the route of the highway, deforestation frontiers were identified at Tambopata-Manu and Tahuamanu. At Tambopata-Manu, deforestation is linked to mining, while at Tahuamanu, it is caused by agricultural and livestock activities. ACCA (2018) notes that one deforestation hotspot (area of high density of forest loss) identified near the Interoceanic Highway was around Iberia. The extensive deforestation here is due to agricultural activity (papaya, cocoa and, particularly, maize growing in the Jewish community of Arca Pacahuara), and an adjacent logging concession. The same source indicates that the South Interoceanic Highway has also suffered the serious impact of deforestation caused by forest fires within $5 \mathrm{~km}$ either side of its route. The construction of networks of secondary forestry roads linking to the South Interoceanic Highway has also facilitated the transportation of illegally logged wood taken from logging and chestnut concessions in the Tahuamanu province (op. cit).

As in other regions, the effects of highway construction in the Ucayali region are also well-known. In 2013, the Atalaya province found itself in a critical situation due to uncontrolled mass immigration and settlement brought about by the construction of the Puerto Ocopa - Atalaya highway, which had been undertaken as a priority. Following its completion, dozens of migrants were arriving directly into the province from the central highlands on a daily basis. Invasions of communal lands and plots, land trafficking and pressure on forest resources, plus their illegal extraction, all consequently increased dramatically. The problem has exceeded the local institutions' capacity to respond and has resulted in chaos. The many highways either under construction or in the pipeline in the southern part of Ucayali therefore represent a risk to the western sector of the Territorial Corridor because, as has happened in neighbouring zones, the area may be invaded and illegal activities flourish, including the plundering of the region's forest resources. This will cause problems for the people in isolation and for maintaining the biodiversity and forests of the Territorial Corridor.

Impacts and threats of deforestation on the peoples in isolation in the Territorial Corridor

The intensive construction of networks of secondary roads in the area of forestry concessions between the Acre and Tahuamanu rivers, adjacent to the Madre de Dios Indigenous Reserve, is destroying the territories of peoples in isolation in this part of the Territorial Corridor. It is having a drastic effect on the soil, water, flora and fauna, fragmenting the territory and breaking up the areas used for hunting and gathering, both essential practices that enable the peoples in isolation to obtain the forest and river resources they need to survive. Road construction is therefore 
seriously affecting the sources of food and the livelihoods of the people living in isolation and, thus, their physical, territorial and sociocultural integrity.

In addition to road construction, tree felling involves the massive presence of forest operators who move constantly throughout the forest, establishing camps that generate organic and inorganic waste, hunting, fishing and gathering products to meet their daily needs, and driving vehicles and operating heavy machinery that cause noise. This has serious implications for the peoples in isolation who are furthermore highly vulnerable to disease, as we have already seen..$^{13}$ Contamination of the environment, soil, water and air with waste, both bodily and food, as well as the materials that are used as part of their forest activity, can all form sources of infection that transmit illnesses such as acute diarrheal disease (ADD), one of the main causes of death among the population in isolation and initial contact, along with parasitosis and anaemia. The pressure placed on the forest animals and fish to feed the teams of workers results in a decline in these vital resources for the people in isolation, and these are their only source of food.

In events and reports produced over the last few years, ${ }^{14}$ the National Indian Foundation of Brazil (FUNAI) has drawn attention both to the increasing density of the Mashco Piro population arriving on the Brazilian side of the border and their dangerous proximity to and hostile acts towards members of indigenous villages. Similar situations arose in these areas towards the end of the 90s, during a time of intense exploitation of high-value forestry resources such as mahogany (Swietenia macrophylla) and cedar (Cedrela odorata). Faced with increasing pressure on and the destruction of their territories and resources between the Acre and Tahuamanu rivers due to logging activity and road construction, the populations in isolation are forced to seek new sources of subsistence and living spaces by moving into nearby areas with similar features. This is a very serious situation and is often a cause of friction both within the isolated group and between them and the loggers and neighbouring residents, generally indigenous, over access to forests and subsistence resources.

It is also important to note the danger of the increasing deforestation being caused by the Jewish settlement of Arca Pacahuara, on the Tahuamanu River, whose crops are now extending into adjacent areas and even into a forestry concession. It should be noted that the most critical deforestation hotspots in Loreto are on the Amazon River, where fast expanding farmland is being established by members of this religious group.

Another of the Territorial Corridor's most threatened borders is to the south, on the upper Madre de Dios River, due to the start of construction of the

13. Some of the peoples in isolation and initial contact affected by epidemics brought into the Territorial Corridor by outsiders in recent years have been: the Nahuas, Chitonahuas, Matsiguenka-Nanti, Matsiguenka of the Paquiría, and Matsiguenka of the Manu. 14. International Congress of Indigenous Peoples of Latin America, CIPIAL. Brasilia, 3 to 5 July 2019. 
Nuevo Edén - Boca Manu - Boca Colorado highway. Although this was brought to a halt in 2015 under pressure from indigenous organisations and SERNANP, it could recommence at any time given that it has the backing of the region's economic and political actors. This highway would intensify the inflow of migrants to the upper Madre de Dios and Manu areas and would result in an expansion of illicit activities such as drug trafficking, which is already a major problem in the region. It would also increase the pressure on the resources of the indigenous territories and protected natural areas, particularly forest species of high commercial value. The population in isolation that would be directly affected by such a scenario would be, firstly, the Mashco Piro living in isolation along the upper Madre de Dios, the Manu River and the Los Amigos river basin; and, secondly, the Matsiguenka living in isolation and initial contact in the upper Manu and Madre de Dios. This is therefore a major threat to these peoples and also to the indigenous Yine, Matsiguenka, Wachipaeri and Arakbut communities in the area.

The intensive settlement occurring in the Atalaya region due to the construction of the Puerto Ocopa - Atalaya highway has extended eastwards in the province and is now threatening the Murunahua, Mashco Piro and Kugapakori Nahua Nanti Territorial Reserves, as well as the Alto Purús National Park and consequently the western part of the Territorial Corridor. The development of new roads between Nueva Italia-Yurúa, Atalaya-Inuya and Sepahua-Poyeni will only exacerbate the pressures on the territories and resources of this part of the Corridor. The peoples that would be directly affected are the Mashco Piro, Chitonahua and other unidentified peoples in isolation; the Nahua and Matsiguenka (from Paquiría, Manu, Camisea and Timpíain) peoples in initial contact; and those organised into communities: Amahuaca, Yaminahua, Yine, Asháninka, Ashéninka and Matsiguenka.

\section{The proposed Territorial Corridor}

The existence of areas contiguously inhabited by peoples in isolation and initial contact has led to the State being asked to provide guarantees of fundamental rights across all of these areas. Different legal categories have, however, now been superimposed on these areas which may be foreign in nature or even in contradiction to, these principles of protection and rights, such as the Permanent Production Forests. The mosaics of land that makes up the continuous territories of peoples in isolation and initial contact are known as territorial corridors. In addition to recognising rights and protections in these areas, the aim is also to improve territorial governance among the organised indigenous population in the surrounding communities and villages who share territory with the peoples in isolation and initial contact. A further aim is the protection of the forests and river headwaters.

The indigenous organisations promoting this initiative are: the Interethnic Association for Development of the Peruvian Forest (Aidesep), the Regional Organisation of Indigenous Peoples of the East (ORPIO), the Regional Organisa- 
tion of Indigenous Peoples Aidesep-Ucayali (ORAU), the Native Federation of the Madre de Dios River and Tributaries (Fenamad), the Machiguenga Council of the Urubamba River (Comaru) and the Regional Coordinating Body of Indigenous Peoples Aidesep-Atalaya (CORPIAA).

Given the many different legal categories, social actors, threats and legal provisions in the territorial corridors, the indigenous organisations have proposed coordination between different government sectors and levels, and their coordination with the indigenous peoples and organisations in order to move towards a strategy that can ensure comprehensive protection by taking a crossborder approach based on the principle of protecting the peoples in isolation and initial contact. Such principles form part of international indigenous rights instruments such as ILO C169 and the UN Declaration on the Rights of Indigenous Peoples, among others. This involves guaranteeing their rights to life, health and self-determination, i.e. their right to decide their own way of life and the nature of their relationship with the surrounding environment without third parties forcing interventions and without assimilation or integration. A further principle is that of legal security and territorial protection, as well as that of prevention in the face of vulnerability, given that these peoples lack any defence against external infectious diseases. Despite these international standards, the State is attempting to side-line indigenous peoples from decisions that affect them such as, for example, the granting of rights to exploit natural resources or construct roads and highways on their territories.

The existence of peoples in isolation and initial contact in most of the Territorial Corridor has been officially recognised by the State, both in the context of creating protected natural areas and in the process of adapting indigenous reserves. Their territorial rights have also, to some extent, been recognised through the classification of these indigenous reserves which, according to legislation, are intangible. The legally anticipated possibility of undertaking activities of "public interest" weakens this protection, however, and makes the people vulnerable. The law on protected natural areas and its implementing regulations indicate that the territorial rights of these peoples are guaranteed, and that precautionary measures will be applied in situations that attempt to transgress them. Nonetheless, inadequate zoning has permitted an external presence and exposed these peoples to forced contact and disease. Legislation also establishes a series of protective measures and mechanisms for these peoples but these have not been implemented efficiently. For example, the protection plans for the indigenous reserves existing in the Territorial Corridor have not yet been implemented despite being officially approved four years ago. ${ }^{15}$ The irony is that it is now nearly time to update them.

The existence of Permanent Production Forests and active forestry concessions superimposed on the Territorial Corridor represents a major threat to the life

15. Protection plans approved via ministerial resolutions 453-2016-MC (Murunahua) and 341-2015-MC (Kugapakori Nahua Nanti). 
of these peoples and ignores the legally-declared protection mechanisms for these indigenous reserves and protected natural areas. It is clear that peoples in isolation and initial contact cannot coexist alongside logging activity.

The indigenous native communities and settlements that share territories with peoples in isolation and initial contact, together with their organisations, are advocating for the protection of the Territorial Corridor for the Pano, Arawak and Other Peoples. To this end, they have made a number of specific proposals. Some communities have been attempting to actively protect these people for decades, in coordination with their local and regional organisations. Others, in contrast, have been exposed to interaction with these peoples, generally in the dry season when they approach the communities in search of food, resulting in tense situations. The presence of logging companies who establish agreements with some communities to extract timber from the communal territories and build forestry roads and highways for this purpose is a serious threat. The people themselves feel that this kind of activity could be eradicated if alternative economic activities were promoted in the communities and if territorial governance were strengthened, ensuring greater control over the leaders' decisions related to the territories and resources existing therein.

\section{Conclusions}

- $\quad$ On the Peru - Brazil border, between the Ucayali, Cusco and Madre de Dios regions and the state of Acre, lies a large area of forest inhabited continuously by a wide range of peoples in isolation and initial contact, along with indigenous peoples organised into communities and settlements sharing these territories. This area, known as the Territorial Corridor of the Pano, Arawak and Other Peoples, is culturally diverse and socially sensitive. It is home to peoples with high immunological vulnerability and to forests of great ecological significance. In addition to the headwaters of rivers of particular relevance for the Amazon Basin, there are also emblematic protected natural areas located here.

- Despite its importance and its high socioenvironmental sensitivity, part of the Territorial Corridor in Madre de Dios is being seriously affected by deforestation due to the construction of a network of roads linking to the South Interoceanic Highway with the aim of forest extraction. The territories of the peoples in isolation living in this part of the Corridor are consequently being fragmented and suffering soil erosion, a decline in soil fertility, compaction, effects on the water cycle, sedimentation, and a loss of plant cover, of carbon capture capacity, and of habitat for wildlife. These drastic effects on the physical and biological environment have a serious impact on the livelihoods of the peoples in isolation by fragmenting and significantly reducing their living spaces and sources 
of food and life. Moreover, the presence of staff from the logging concessions exposes them to infectious diseases against which they have no immunological defence, and creates conflict over their living space.

- At the same time, a series of road projects being promoted both by the national and regional governments is threatening the Territorial Corridor on all sides. The incentive behind the construction of these highways is largely natural resource exploitation, specifically wood and gold, which is in response to global demand. Road construction is consequently being promoted by specific interest groups that hold political and economic influence. Their aim is to achieve their objectives as rapidly as possible and so they begin building the highways, even large ones such as the South Interoceanic Highway, without first undertaking cost/benefit, viability or sustainability analyses and without having considered the fundamental rights that may be affected or the socioenvironmental impacts. Corruption is an additional problem related to the implementation of these road projects. This has become clear in recent years as multi-million bribes have come to light, paid by companies to ensure they are given the contracts to projects such as the South Interoceanic Highway.

- Faced with these pressures and threats, the indigenous organisations of the Peruvian Amazon, together with indigenous organisations from Acre, have made a proposal to the Peruvian and Brazilian governments aimed at ensuring the comprehensive protection of the Territorial Corridor of the Pano, Arawak and Other Peoples, an initiative that includes recognising the rights of these indigenous peoples, guaranteeing the intangibility of their territories, ensuring territorial governance in the indigenous communities and settlements, and protecting the basin headwaters and forests.

- Lastly, it is important to note that, in addition to addressing the demands of the indigenous organisations to expand the Madre de Dios Indigenous Reserve to the east, where intensive forest extraction and road construction is being conducted, the State needs -by means of a supreme decree- to commit to a presence in the area and to implement urgent measures to eradicate the pressures of logging in the territory of the peoples in isolation, guaranteeing its integrity and sociocultural continuity. 


\section{BIBLIOGRAPHY}

ALBERTI, J. and Pereyra, A. (2018). Carretera Interoceánica IIRSA Sur de Perú: un megaproyecto con preinversión express. Banco Interamericano de Desarrollo, serie: Estudios de Caso de Megaproyectos.

ASOCIACIÓN PARA LA CONSERVACIÓN DE LA CUENCA AMAZÓNICA, ACCA. (2016). Construcción de una nueva carretera entre el Parque Nacional del Manu y la Reserva Comunal Amarakaeri (Madre de Dios), MAAP N ${ }^{\circ} 29$. Available at https: / / maaproject. org/2016/nueva_carretera_manu/ (Accessed in June 2019).

ASOCIACIÓN PARA LA CONSERVACIÓN DE LA CUENCA AMAZÓNICA, ACCA. (2018a). Deforestación en la Amazonía Andina (Tendencias, Hotspots, Drivers). MAAP Síntesis \#3. Available at: https:/ / maaproject.org/2018/ sintesis3/ (Accessed in July 2019)

ASOCIACIÓN PARA LA CONSERVACIÓN DE LA CUENCA AMAZÓNICA, ACCA. (2018b). Propuesta de carretera cruzaria bosque primario fronterizo. MAAP N ${ }^{\circ} 76$ Available at https: / / maaproject.org/2018/ purus / (Accessed in June 2019)

CORPORACIÓN ANDINA DE FOMENTO, CAF. (2013). Carretera Interoceánica Sur del Perú. Retos e innovación. Bogota.

DAMMERT, J.L. (2018). Salvaguardas ambientales y sociales en el financiamiento de proyectos de infraestructura en la Amazonía sur del Perú. Global Development Policy Center-Boston University.

DOUROJEANNI, M. (2006). Estudio de caso sobre la Carretera Interoceánica en la Amazonía Sur del Perú. Labor, Bank Information Centre, Conservation International, DAR, Lima.

GESTIÓN. (2018). Deforestación y los retos del Estado peruano. Published 02 January 2019. Available at: https: / / gestion.pe / opinion/ deforestacion-retos-peruano-254483 (Accessed in June 2019).

HUERTAS, B. (2015). Corredor territorial de pueblos indígenas en aislamiento y contacto inicial Pano, Arawak y otros. Diagnóstico y fundamentos antropológicos. Plataforma de organizaciones para la protección de los pueblos en aislamiento y contacto inicial (Asociación Interétnica de Desarrollo de la Selva Peruana (Aidesep), Organización Regional de Pueblos Indígenas del Oriente (ORPIO), Organización Regional de Pueblos Indígenas Aidesep-Ucayali (ORAU), Federación Nativa del río Madre de Dios y Afluentes (Fenamad), Consejo Machiguenga del río Urubamba (COMARU), Coordinadora Regional de Pueblos Indígenas Aidesep-Atalaya (CORPIAA). Lima.

INSTITUTO NACIONAL DE ESTADÍSTICA, INEI. (2008). Censos Nacionales 2007: XI de Población, VI de Vivienda. Primeros resultados, Perú: crecimiento y distribución de la población, Lima. MINISTRY OF ENERGY AND MINES - Provincial Municipality of Atalaya. (2007). Plan Base de Ordenamiento Territorial. Provincia de Atalaya, Atalaya.

MINISTRY OF THE ENVIRONMENT. (2016). Por qué no debe aprobarse el predictamen de insistencia de la ley sobre la carretera de Madre de Dios, tramo Nuevo Edén-Boca Manu-Boca Colorado. Available at: http://www.minam.gob.pe/wp-content/uploads/2016/02/ Dossier-Carretera-Boca-Manu.pdf (Accessed in June 2019)

MINISTRY OF THE ENVIRONMENT. (2017). Cobertura y deforestación en los bosques húmedos amazónicos. Available at: http:/ / geo.serfor.gob.pe/geoserfor/images/Reporte_ Bosques /Cobertura_y_Deforestacion_en_los_Bosques_Humedos_Amazonicos_al_2017. pdf (Accessed in June 2019) 
MINISTRY OF THE ENVIRONMENT. (2018). Presentan datos sobre apertura de caminos en el bosque amazónico. Press release published 06 June 2018. Available at: http: / / geobosques. minam.gob.pe/geobosque/view / blog/ ?p=51 (Accessed in June 2019).

RED AMAZÓNICA DE INFORMACIÓN SOCIOAMBIENTAL GEORREFERENCIADA, RAISG. (2019). Presiones y amenazas sobre las áreas protegidas y los territorios indígenas de la Amazonía. Available at: https: / / www.amazoniasocioambiental.org/es/publicacion/ presiones-y-amenazas-sobre-las-areas-protegidas-y-los-territorios-indigenas-de-la-amazonia-2/ (Accessed in June 2019)

SECRETARY OF STATE FOR THE ENVIRONMENT, SEMA, et al. (2010). Zoneamiento Ecológico Econômico do Acre. $\mathrm{O}$ uso da terra acreana com sabedoria. Resumo educativo. Rio Branco-Acre.

SERVICIO NACIONAL FORESTAL Y DE FAUNA SILVESTRE. (2018). Gobierno presentó cifras de deforestación del 2017 y las principales acciones para combatirla. Press release issued 22 December 2018. Available at https:/ / www.serfor.gob.pe/noticias / gobierno-presento-cifras-de-deforestacion-del-2017-y-las-principales-acciones-para-combatirla. (Accessed in June 2019).

SOCIEDAD PERUANA DE DERECHO AMBIENTAL - Actualidad ambiental. (2018). La deforestación registrada el 2017 en Madre de Dios fue la más alta de los últimos 17 años. E-bulletin published 19 December 2018. Available at: http://www.actualidadambiental. pe / $p=53757$ (Accessed in June 2019).

VILLA, L., Finer, M. (2019). Identificando Tala Ilegal en la Amazonía Peruana. MAAP: 99. Available at: https: / / maaproject.org/2019/ maap99-tala-ilegal/ (Accessed in July 2019)

WORLD WIDE FUND FOR NATURE, WWF, et al. (2012). Opinion on Draft Bill of Law $1035 / 2011-C R$ aimed at declaring the public necessity and priority national interest of providing an overland connection between the town of Puerto Esperanza in the border province of Purús, in Ucayali region, and the town of Iñapari in the border province of Tahuamanu, Madre de Dios region, by means of a road or rail link between Puerto Esperanza, capital of Purús, and Iñapari, capital of Tahuamanu, Lima. 


\title{
AUTHOR BIOGRAPHIES
}

\begin{abstract}
Alberto Chirif is an anthropologist from the San Marcos National University. He has been working on Amazonian issues since 1970, particularly in relation to indigenous peoples' collective rights. He has worked as an independent consultant since 1995 although, from March 2001 until its completion in mid-2003, he ran the Pacaya Samiria Integrated Conservation and Development Programme with funding from WWF-AIF Denmark. He is the author of numerous specialist articles and a contributor to many co-authored volumes, including Atlas de Comunidades Nativas (1977), El Indigena y su Territorio (1991) and Marcando Territorio. Progresos y limitaciones de la titulación de territorios indígenas en la Amazonía (2007). He is also sole author of such books as: Pueblos Indígenas Amazónicos e Industrias Extractivas. (Lima, 2011); La historia del Tahuayo contada por sus moradores (2013); Pueblos de la yuca brava. Historia y culinaria. (2014); Diccionario Amazónico. Voces del castellano en la selva peruana. (2016); and Después del Caucho (2017).
\end{abstract}

Beatriz Huertas Castillo is an anthropologist with a Master's in Amazonian Studies from the San Marcos National University. She holds diplomas from UNDP, the OAS and the Catholic Pontifical University of Peru - Revenue Watch. From 1994 to 1996 she worked on Aidesep's “Titling of lands, communal and territorial reserves" project in Pucallpa. From 1997 to 2002 she was a member of Fenamad's (Native Federation of the Madre de Dios River and its Tributaries) technical team, with responsibility for producing the anthropological justification for indigenous peoples' territorial rights in that department, including peoples living in isolation in the north of Madre de Dios. From 2003 to 2005 she coordinated Aidesep's National Programme for Peoples Living in Isolation and Initial Contact and, from 2006 to 2010, she was the technical secretary of the International Indigenous Committee for the Protection of Peoples Living in Isolation and Initial Contact in the Amazon, Gran Chaco and Eastern Regions of Paraguay (Cipiaci). Together with the UN, the Inter-American Commission on Human Rights and IWGIA, she has contributed to the planning and implementation of actions aimed at guaranteeing the rights of indigenous peoples living in isolation and initial contact. She is currently working with the Norwegian Rainforest Foundation supporting indigenous Amazonian organisations to implement their strategies and actions to protect peoples living in isolation and initial contact, provide territorial management and ensure forest protection. She is the author of Los pueblos en aislamiento, su lucha por la sobrevivencia y la libertad (2002), Pueblos indígenas y movimiento social en Madre de Dios (2010), Agua, Cultura y Territorialidad en el pueblo Shawi del río Sillay (2011) and Corredor territorial Pano, Arawak y otros (2015), in addition to numerous articles. 
Carlos Cañas is currently working as principal investigator and associate professor in the Agua Research and Technology Centre (CITA) of the Engineering and Technology University (UTEC). He holds a degree in Biology from the San Marcos National University (UNMSM), and received his Master's (2007) and his doctorate (2012) from the University of Florida. He has previously been a researcher at the Natural History Museum (UNMSM), with Conservation International-Peru, in the Association of the Conservation of the Amazon Basin (ACCA) and with the Wildlife Conservation Society (WCS). His research began with the taxonomy of freshwater fish and then extended to knowledge of fisheries and fish migrations in the Madre de Dios basin; in recent years, he has focused on improving integrated fisheries and wetlands management as a more effective way of conserving the aquatic biodiversity and fishery resources of the Peruvian Amazon.

Claudia María Gálvez Durand is a naturalist trained in the Biological Sciences, and who holds a Master's in Forest Resource Conservation as well as diplomas in Biodiversity Management and Climate Change. She has wide working experience of indigenous and mestizo Amazonian peoples living adjacent to protected natural areas. Her professional experience is based on respect, recognition and appreciation of traditional and local knowledge and its incorporation into natural resource and territorial management as well as climate change adaptation and mitigation strategies.

Dennis del Castillo Torres is an agronomist with an M.Sc. and a Ph.D. in crop physiology, soil physics and natural resource conservation from Mississippi State University. He is currently the Forest Management and Environmental Service Program Director at the Peruvian Amazon Research Institute (IIAP). He has more than 25 years of experience in conducting participatory research with local communities and in implementing projects involving rural development, biodiversity conservation, soil and forest management, as well as the sustainable use of natural resources. He has in-depth knowledge of rural life in various Amazonian and African countries. Over the last 15 years, he has become a tireless fighter in defense of the sustainable management and conservation of Amazonian wet and peatlands.

Ermeto Tuesta is a member of the Awajún people of Peru and is a technician in computer and information science specialising in Geographic Information Systems (GIS). He worked in the "Economic Strategies and Indigenous Peoples" project (Oxfam América/COICA) in 1993 and then moved to Oxfam America until 1998 where he worked as a GIS specialist. Since then, he has been working in the Land Management Unit of the Institute for the Common Good (Instituto del Bien Común). He has helped publish this institution's three atlases on native communities: on the central and north-eastern forests of Peru (2006, 2011 and 2017). He worked with the lawyer, Pedro García Hierro, to produce the integrated territorial proposal for 
nine indigenous peoples in Datem del Marañón and on the integrated titling of the Rama-Kreol indigenous people in Nicaragua.

Eurídice Honorio Coronado. Researcher at the Instituto de Investigaciones de la Amazonia Peruana, Iquitos, Peru. She studies at the Universidad Nacional Agraria La Molina, Lima, Peru and subsequently completed a Masters in the Biodiversity and Taxonomy of Plants at the Royal Botanic Garden Edinburgh (RBGE), and her PhD jointly between the University of Leeds, UK and RBGE. Her research interests span the population genetics of Amazonian trees with a particular focus on timber species, the floristic composition, dynamics and sustainable use of Amazonian forests.

Guillermo Reaño is a writer, educator and journalist specialising in the environment and rural development. He was previously a history teacher for more than 30 years in Los Reyes Rojos school, an institution he ran until leaving his job to spend his time to travelling the world recording and writing the histories of men and women who are fighting to build a better and more caring future. He set up the Diploma in Sustainable Tourism Innovation and Management at the Antonio Ruiz de Montoya University in Lima and is Vice-President of the Peruvian Association of Adventure Tourism and Ecotourism (APTAE). He regularly writes articles and investigative reports for the environmental agency Mongabay Latam, for the Caretas and Viajeros reviews and for the digital platforms Solo para Viajeros and La Mula. He is the author of: Nuestra Historia. Relatos de historia del Perú para Niños (1986), Los Años Difíciles, 1865-1919 (1990), Viajando por el Perú (2002), Sonriéndole al futuro. Iniciativas en turismo sostenible en el Perú (2005), and Voces de la Amazonía. Un viaje por el territorio de la esperanza (2016).

Hugo Cabieses is a Peruvian economist from the University of the Pacific in Lima, with further qualifications from the universities of Lund in Sweden (Latin American industrialisation policies); Utrecht in the Netherlands (industrialisation and regionalisation in Peru); and the University of the Pacific in Lima (voluntary carbon markets). He has trained in Feldafing, Bielefield, Germany (rural development in tropical zones) and CATIE, Turrialba, Costa Rica (climate change mitigation through REDD, reforestation and forestation). He has been a parliamentary advisor (2016-2017); chief advisor to the Governor of Cajamarca (2015-2016); advisor to the general management of Lima's Santa Anita Grand Wholesale Market (2013-2015); Vice-Minister of Strategic Natural Resource Development in the Ministry of Environment (August-December, 2011); national coordinator for the DRIS/ ZA-MANU project on sustainable forest management in the Manu National Park (2006-2010); and a consultant on issues of coca, drugs policy, sustainable development, forest management and climate change. He is currently a member of the Pan-Amazon Social Forum (FOSPA) and chief advisor to Congresswoman Katia Gilvonio of the Frente Amplio, representing the Junín Region. 
Ian Lawson. Senior Lecturer in the School of Geography and Sustainable Development, University of St Andrews, U.K. His research focuses on understanding the development of ecosystems on long timescales (centuries to tens of millennia), and on understanding long-term human impacts on the environment. Following an MA and PhD from the University of Cambridge, he has worked in the Mediterranean and in the islands of the North Atlantic, and since 2010 on peat-forming ecosystems in Peru and in central Africa.

José Álvarez Alonso is a biologist who has studied as a post-graduate at the Smithsonian Institute and Louisiana State University. He specialises in the conservation, community management and sustainable use of the Amazon's biodiversity, with an emphasis on wildlife and ornithology. His research has appeared in different specialist media and he has published hundreds of articles on biological diversity, indigenous peoples and Amazonian development. From 1996 to 2012 he worked as a researcher and consultant on wildlife management at the Research Institute for the Peruvian Amazon. Between July 2012 and April 2017 he was the Director General for Biological Diversity in the Ministry of the Environment. From May 2017 to May 2018 he worked in the organisation Naturaleza y Cultura Internacional. Since 2018, he has been Director-General for Biological Diversity in the Ministry of the Environment. Among other things, in 2005 he received the City of Iquitos Award for Scientific Merit; in 2006, the Parker-Gentry Award from the Field Museum in Chicago; and in 2014 an honorary doctorate from the Trujillo National University. He has received a number of journalism awards for his articles on Amazonian reality, a tree species and an orchid species. A biological station in the forest has been named in his honour. He is visiting professor on the Master's course in Higher Amazonian Studies of the PUCP, at Trujillo National University and at the International University of Andalucía in Spain, among others.

Juan Luis Dammert holds a doctorate in geography from Clark University (Massachusetts, USA) and a first degree in sociology from the Catholic Pontifical University of Peru (PUCP). He is currently working for Oxfam in Peru. He has been a researcher with the Peruvian Environmental Law Society and a consultant for the University of the Pacific, Wildlife Conservation Society, Grade and the Initiative for Conservation in the Andean Amazon (USAID's ICAA), among others. His main areas of research are natural resource governance and socio-environmental conflicts, from the perspective of political ecology and critical geography. His doctoral thesis focused on the issue of oil palm expansion in the Peruvian Amazon.

Julia Urrunaga is Peru Director for the Environmental Investigation Agency, an international NGO in which she is working to expose forest crime, amplify local peoples' voices, and promote new policy measures to help eliminate illegally-sourced timber and forest products from global markets, shifting demand to- 
wards legal and sustainable products. Together with EIA, she was the lead author of three multiannual investigative reports: "The Moment of Truth" (2018) and "The Laundering Machine" (2012) about illegal logging in Peru and its exports to international markets -including the US, EU and China- and "Deforestation by Definition" (2015), which focused on the illegal deforestation of Peru's natural Amazon forests to replace them with large-scale monocrop agribusinesses, mostly oil palm plantations. She holds a Master's degree in International Relations and a Diploma in Sustainable Development from Yale University -where she focused on governance, transparency and participation issues- and a Bachelor's degree in communications from Lima University. Prior to EIA, she spent 14 years working as an investigative journalist, focusing on corruption issues. She received several national and international awards for journalism, including from the Inter-American Press Association and the Gabriel Garcia Marquez' Foundation for New Ibero-American Journalism. She has also lectured in journalism at the Catholic Pontifical University of Peru (PUCP) and the Peruvian University of Applied Sciences (UPC), and worked as an associate to the Council on Latin American and Iberian studies at Yale University.

Katherine Roucoux. Senior Lecturer in the School of Geography and Sustainable Development at the University of St Andrews. Her research focuses on long-term ecology and palaeoclimatology on timescales of centuries to hundreds of millennia using palaeoecological methods, in particular sub-fossil pollen and sediments, to reconstruct past vegetation responses to climatic change and anthropogenic activity during the Pleistocene and Holocene. Following a $\mathrm{PhD}$ from the university of Cambridge, she has worked in southern Europe, Iceland and currently works on peatland ecosystems in western Amazonia.

Luisa Elvira Belaunde is from Peru and holds a doctorate in anthropology from the London School of Economics. She is currently Principal Professor at the department of Anthropology of the Universidad Nacional Mayor de San Marcos, Peru. She specialises in Amazonian ethnology and has published various articles and books, including: Viviendo Bien: Género y Fertilidad entre los Airo Pai de la Amazonía Peruana (Lima: CAAAP, 2001), El Recuerdo de Luna: género, sangre y memoria entre los pueblos amazónicos (Lima: CAAAP 2008) and Kene: ciencia arte y tradición (Lima: Ministry of Culture, 2009).

Manuel Martín Brañas. Researcher in the Programa de Investigación de la Diversidad Cultural y Economía Amazónica of the Instituto de Investigaciones de la Amazonía Peruana (IIAP) in Iquitos, Peru. He graduated in Philosophy and Arts from the Universidad Autónoma in Madrid and holds a Masters degree in rural sustainable development. He has led many international research and development projects in Amazonia, related to rural development, bilingual education, forest conservation, and the valuation of the traditional knowledge of indigenous peoples. 
Mariana Montoya. Country Director for the Wildlife Conservation Society (WCS) in Peru. She obtained her PhD in Geography and the Environment from the University of Texas - Austin, where she focused on the sustainability of socioecological systems in the Peruvian Amazon. Mariana's Ph.D. dissertation examined how the Kandozi indigenous group of Loreto governs access to fish, how this access contributes to their well-being, and if the Kandozi's natural resource use is sustainable. Previously, she obtained her master's degree in Ecosystem Management in the Autonomous University of Baja California in Mexico and her undergraduate degree in Biology in the National Agrarian University La Molina, Peru. Along her career, Mariana has worked in protected areas management, marine and freshwater conservation, has participated in Environmental Impact Assessment and for the last 15 years she has led in the design, implementation, and supervision of various projects of biodiversity conservation, indigenous organization strengthening, natural resource management, watershed management, combating wildlife trafficking and environmental threat mitigation in Peru.

Richard Chase Smith is an anthropologist with a doctorate in anthropology and linguistics from Cornell University and a post-doctorate from Harvard. He has worked with different indigenous peoples of the Andean Amazon in Ecuador, Peru and Bolivia. His research has focused on Amazonian indigenous peoples' ownership, possession and use of land and natural resources; the social management of natural resources in indigenous and riverine communities of the Peruvian Amazon; the relationship between conservation and development in the Amazon with a focus on local participation in conservation efforts; and the application of GIS and remote detection technology to the benefit of indigenous peoples. He has published numerous studies on these issues. He has also researched the historical/ cultural space of the Yánesha indigenous people. He is the founder and current Executive Director of the Institute for the Common Good. He ran Oxfam America's South America programme for 12 years.

Sandra Ríos is a geographical engineer specialising in Amazon deforestation, and she has a background in research into and the application of mapping information. She forms part of the technical team of the Amazonian Network for Georeferenced Socioenvironmental Information (RAISG), representing the Institute for the Common Good. More recently, she has worked on analysing deforestation in the Peruvian Amazon, identifying its causes and factors, and has published studies and maps on deforestation in different parts of the Peruvian Amazon, gathering information for the georeferencing of native communities, developing participatory maps and validating maps of deforestation in the field. She undertook her post-graduate studies at the University of Bogotá and the La Molina National Agrarian University. 
Shapiom Noningo Sesen is from the Wampis Nation of Peru, born in Puerto Galilea community, Santiago River (Kanus in the Wampis language). He holds a Bachelor's degree in Psychology, specialising in community and organisational psychology. He has previously been President of the regional office of the Aguaruna and Huambisa Council; first president of the Regional Organisation of Indigenous Peoples of the Peruvian Amazon (Orpio); and vice-president of Aidesep. He is currently working in Perú Equidad as a technician on indigenous communities' and peoples' issues.

Thomas Moore is an anthropologist and graduate of the New School for Social Research doctoral programme in New York. He is co-founder and former director of the Eori Centre for Regional Research and Promotion in Puerto Maldonado (Peru), and external advisor to the Native Federation of the Madre de Dios River and its Tributaries (Fenamad). His experience in the Peruvian forests and, especially Madre de Dios, dates back to 1971 and has continued ever since.

Timothy Baker. Professor of Tropical Forest Ecology and Conservation at the University of Leeds, UK. He holds an MA from the University of Cambridge and PhD from the University of Aberdeen. His research explores the trajectory of the carbon stocks and tree biodiversity of tropical forests across Amazonia, the evolution of the tropical flora, and the ecology and sustainable use of Amazonian peatlands. 


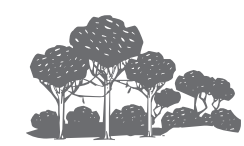

Este libro se imprimió en diciembre de 2019, en los talleres de Tarea Asociación Gráfica Educativa Pasaje María Auxiliadora 156, Breña - Lima

Correo e.: tareagrafica@tareagrafica.com

Página web: www.tareagrafica.com

Teléf. 332-3229 / 424-8104 / 424-3411 


First published in Spanish in 2018, this English edition does not follow the exact same format as the original because, in addition to several new works, two have been removed because they are on topics that are no longer current or which have changed in the last two years, and several more have been updated by their authors.

This publication forms part of a project on the Reducing Emissions from Deforestation and Degradation (REDD+) mechanism. The project is being funded by Norway's International Climate and Forest Initiative (NICFI) and is providing support to Servindi (Intercultural Communication Services), Onamiap (National Organisation of Andean and Amazonian Indigenous Women of Peru) and Coharyima (Harakbut, Yine and Matsiguenka Council), this latter being a member organisation of Fenamad (Federation of Native Communities of Madre de Dios and its Tributaries) in Madre de Dios. The key aim of the project is to provide training for indigenous communicators and to produce and disseminate information on indigenous rights with a focus on climate change issues, the Norway-Germany-Peru cooperation agreement on REDD+ and the indigenous REDD+ proposal aimed at titling the communal territories. This work is being undertaken largely in the REDD+ pilot areas: Madre de Dios, Ucayali and San Martín.

One of the project's themes is the drivers of deforestation. To consider this issue in more depth, a workshop was held in Puerto Maldonado (Madre de Dios, Peru) on 26 March 2017 with the participation of communities affiliated to Coharyima and the leaders and technical staff of Fenamad. The primary aim was to analyse the issue of road infrastructure, not only the Southern Interoceanic Highway linking the Madre de Dios region to Acre State in Brazil but also other planned roads that are likely to cross the indigenous territories and protected natural areas.

This work brings together a number of the speeches and discussions that took place during that workshop along with articles written especially by the authors. It comprises a total of 14 articles addressing the issue of deforestation in the Peruvian Amazon and its impacts, not only on the Amazonian environment and wildlife but particularly on the societies inhabiting the area. These impacts are being facilitated by informal dynamics for which the State is largely responsible. It has failed to act promptly enough to put a stop to these dynamics and redirect their drivers towards a sustainable use of the environment and its resources which would, in turn, result in prosperity for the region and the country as a whole. The most harmful of these dynamics is the expansion of illegal coca growing and alluvial mining. The environmental impacts are, nonetheless, also the result of official policies aimed solely at promoting economic growth that benefits the investment companies to the detriment of the population and the environment. The State has promoted such policies through a strategy of tax reduction (meaning less public investment in social services such as education and health) and a lowering of environmental standards and social rights, such as job security. Their policies have also included the construction of roads that enable companies and extractors alike to gain easy access to new areas rich in natural resources, and which are then rapidly plundered. As recent judicial inquiries have shown, these infrastructure projects are based on a logic of corruption rather than national interest. As for the indigenous peoples, they are suffering serious aggression aimed above all at minimising, or even trying to abolish, the rights protecting them, such as the guarantee of free, prior and informed consultation as provided by ILO C169, the aim of which is to reach an agreement on initiatives affecting them.

Alberto Chirif
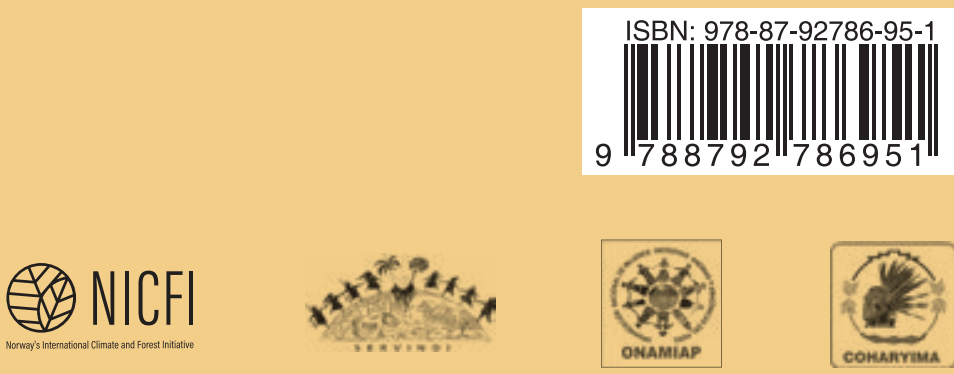